\title{
Współczesna Azja: aspekty polityczne, społeczne i kulturowe
}

Redakcja naukowa Joanna Marszałek-Kawa Jakub Zajączkowski 


\author{
Seria \\ Biblioteka Azji i Pacyfiku \\ Redaktor Serii \\ Joanna Marszałek-Kawa \\ Sekretarz Serii \\ Bartosz Ptotka \\ Rada Serii \\ Kamal M. Abdulla (Azerbejdzan), Daulet L. Baideldinov (Kazachstan), \\ Marceli Burdelski (Gdańsk), He Yaomin (Chiny), \\ Hassan A. Jamsheer (Łódź), Vasyl Marchuk (Ukraina), \\ Joanna Marszatek-Kawa (Toruń), Miao Huashou (Chiny), \\ Vladimir I. Nifadiev (Kirgistan), Ewa Oziewicz (Gdańsk), \\ Zdzisław Puślecki (Poznań), Akmal Saidov (Uzbekistan), \\ Grażyna Strnad (Kraków), Peter Vorel (Czechy) \\ Recenzenci tomu \\ prof. dr hab. Andrzej Stelmach \\ prof. dr hab. Miao Huashou \\ Redaktor prowadzący: Daniel Kawa \\ Redakcja techniczna: Ryszard Kurasz \\ Korekta: Zespót \\ Projekt okładki: Krzysztof Galus \\ (C) Copyright by Wydawnictwo Adam Marszałek
}

Wszystkie prawa zastrzeżone. Książka, którą nabyłeś, jest dziełem twórcy i wydawcy. Żadna jej część nie może być reprodukowana jakimkolwiek sposobem - mechanicznie, elektronicznie, drogą fotokopii itp. - bez pisemnego zezwolenia wydawcy. Jeśli cytujesz fragmenty tej książki, nie zmieniaj ich treści i koniecznie zaznacz, czyje to dzieło

Toruń 2020

\title{
ISBN 978-83-8180-512-4
}

VII Międzynarodowy Kongres Azjatycki „Budowanie przyszłości państw: Tradycja,

Teraźniejszość, Przyszłość" - zadanie dofinansowane w ramach umowy nr DNK/SP/4662466/2020 ze środków Ministra Edukacji i Nauki przeznaczonych na działalność upowszechniającą naukę

Wydawnictwo prowadzi sprzedaż wysyłkową:

tel./fax 5664422 35, marketing@marszalek.com.pl

Wydawnictwo Adam Marszałek, ul. Lubicka 44, 87-100 Toruń

tel. 5666422 35, e-mail: info@marszalek.com.pl, www.marszalek.com.pl

Drukarnia, ul. Warszawska 54, 87-148 Łysomice, tel. 566783478 


\section{Spis treści}

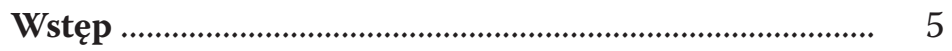

\section{Robert Jakimowicz}

Współczesne stosunki rosyjsko-indyjskie: aspekty

polityczne, militarne i gospodarcze

\section{Aleksandra Czubak}

Funkcjonowania japońskich przedsiębiorstw

w Polsce - uwarunkowania kulturowo-prawne

68

\section{Lukasz B. Pilarz}

Recycling statków a ochrona środowiska wód morskich na przykładzie stoczni złomowych w Indiach i Bangladeszu

\section{Grażyna Strnad}

Studia koreanistyczne w Polsce - geneza, ewolucja,

\section{Dariusz Jędrasiak}

Dyplomacja edukacyjna w procesie kształtowania wizerunku Japonii. Studium przypadku relacji

z Polską 
Beata Pietkiewicz-Pareek

Zdalna edukacja w Indiach w czasach pandemii

Covid-19

\section{Renata Ziobro}

Hell Joseon - neologizm czy zjawisko społeczne we współczesnej Republice Korei?
Aleksandra Kobylańska
Wychowanie do wartości dzieci i młodzieży
w Japonii

\section{Iwona Grodź}

Akira Kurosawa: artysta między Wschodem

a Zachodem 207

\section{Dorota Kamińska-Jones}

Tradycja i współczesność w kulturze indyjskiej na przykładzie świata urody kobiety 


\section{Wstęp}

Od początku XXI w. region Azji odgrywa istotną rolę w stosunkach międzynarodowych. Wynika to z dynamiki gospodarczej regionu oraz wzrostu mocarstwowości państw azjatyckich, takich jak Chiny czy Indie. O specyfice i tożsamości współczesnej Azji decydują jednak nie tylko aspekty geopolityczne i geoekonomiczne, połączenie cech regionalizmu lądowego i morskiego, ale również uwarunkowania kulturowe i społeczne. Rola tradycji i wartości w życiu społecznym, w kształtowania systemów politycznych, budowaniu tożsamości państw, znaczenie edukacji w państwach azjatyckich i jej rola zwłaszcza w tworzeniu nowych elit społecznych, politycznych, kwestia demokracji liberalnej versus demokracji nieliberalnej to dylematy i zagadnienia, przed którymi stanęły państwa regionu Azji.

Współzależności tych zjawisk społecznych, ich rola w kształtowaniu procesów politycznych i gospodarczych stały się przyczynkami do rozważań nad współczesną Azją. Jest to tym ważniejsze, iż obecnie większość publikacji dotyczących Azji koncentruje się na kwestiach bezpieczeństwa, gospodarki czy roli mocarstw takich jak USA, Chiny, czy Indie. Niewiele jest publikacji, które w sposób holistyczny analizują współzależności między zagadnieniami kulturowymi, prawnymi, gospodarczymi i politycznymi ${ }^{1}$.

1 J. Nakonieczna, J. Zajączkowski (red.), Azja Wschodnia i Azja Po- 
Uwarunkowania społeczne i kulturowe mają zaś we współczesnej Azji kluczowe znaczenie. Bez ich zrozumienia, poznania nie jest możliwa kompleksowa analiza polityki wewnętrznej i zagranicznej. Z jednej strony dynamiczne zmiany, reformy gospodarcze, modernizacja, z drugiej tradycja, ciągłość, wartości wymagają od państw regionu ciągłej adaptacji i kształtowania zarówno polityk publicznych, jak i zagranicznej.

Biorąc pod uwagę powyższe założenia celem publikacji jest wielowymiarowa analiza znaczenia uwarunkowań politycznych, kulturowych i prawnych dla polityki wewnętrznej oraz dla różnych aspektów stosunków zewnętrznych, takich jak relacje bilateralne, aktywności handlowe i inwestycyjne państwa. Publikacja nie ma ambicji wypełnienia w całości tego zadania. Jej zamiarem jest zarys problematyki, wprowadzenie do analizowanych zagadnień, a przede wszystkim wskazanie na znaczenie współzależności między kulturą, edukacją, polityką i gospodarką we współczesnej Azji.

Temu celowi została podporządkowana struktura książki. Można ją podzielić na dwie główne części. Pierwsza porusza w różnym kontekście relacje zewnętrzne państwa, ukazane są jej uwarunkowania kulturowe, społeczne, ekonomiczne. Druga część skupia się na problematyce wewnątrzkrajowej.

Publikację otwiera artykuł Roberta Jakimowicza o relacjach indyjsko-rosyjskich po zakończeniu zimnej wojny. Autor omawia ewolucję, dynamikę oraz problemy i wyzwania w stosunkach politycznych, gospodarczych i militarnych tych dwóch państw. Jakimowicz wskazuje, że obydwa pań-

tudniowa w stosunkach międzynarodowych, Warszawa 2011; A. Jarczewska, J. Zajączkowski (red.), Region Azji i Pacyfiku w latach 1985-2015, Warszawa, 2016; J. Marszałek-Kawa, J. Zajączkowski (red.), Wspótpraca i rywalizacja państw azjatyckich, Torun 2019. 
stwa traktują wzajemne relacje jako kluczowe w swojej polityce zagranicznej. Zwłaszcza uwidoczniło się to w XXI w. w wymiarze politycznym. Jednocześnie badacz podkreśla, że na rozwój relacji politycznych między Delhi i Moskwą pozytywny wpływ miało dziedzictwo zimnej wojny i sojusz w tym okresie ZSRR i Indii. Warto w tym kontekście podkreślić, że także w wymiarze społecznym, kulturowym i międzyludzkim wzajemne relacje były także rozwijane, zwłaszcza od lat 70. XX w. Mimo tych pozytywnych przejawów relacji Indii i Rosji ostatnie lata XXI w. wskazują, że rola Rosji będzie się zmniejszać. Dowodzi tego chociażby dywersyfikacja zakupów broni i technologii wojskowych przez Indie, które chcą w tym zakresie zmniejszyć zależność od Rosji. Ponadto fakt, że Rosja nie jest nawet w pierwszej dziesiątce partnerów handlowych Indii świadczy, że relacje te mają przede wszystkim znaczenie w wymiarze politycznym.

Aleksandra Czubak zwraca uwagę w swoim artykule, że choć normy prawne w kontekście prawa gospodarczego, handlowego dotyczące działalności przedsiębiorstw są podobne w Polsce i w Japonii, to kluczową kwestią jest fakt różnego stosowania i interpretowania prawa. Wynika to $\mathrm{z}$ kontekstu kulturowego i religijnego. Badaczka omawia problematykę kultury prawnej w Polsce i Japonii, zaznaczając obszary prawa, w których różnice w jego interpretowaniu mają znaczenie dla funkcjonowania przedsiębiorstw japońskich w Polsce.

Łukasz B. Pilarz porusza kwestię ochrony środowiska przed odpadami, jakim jest recyclingu statków, na przykładzie państw Azji Południowej, czyli Indii i Bangladeszu. Badacz podkreśla, że w porównaniu do państw europejskich, w krajach Azji Południowej normy ochrony środowiska w tym zakresie są znacznie słabiej egzekwowane. To jest 
głównym powodem, że znaczna część statków do rozbiórki kierowana jest do państw Azji Południowej. Społeczność międzynarodowa od dłuższego już okresu obserwuje fakt braku wystarczającej skuteczności prawnych instrumentów reglamentacyjnych w dziedzinie prewencji zanieczyszczenia odpadami ze statków w państwach Azji Południowej. Państwa tego regionu, mimo jednak istnienia w tym zakresie konwencji międzynarodowych i zwracania uwagi na ten proceder przez społeczność międzynarodową, nie podejmują jednak de facto żadnych kroków, które świadczyłyby o zmianie polityki w tym zakresie.

Grażyna Strnad omawia genezę, rozwój i znaczenie studiów koreanistycznych w Polsce. Badaczka wskazuje, że wśród czynników służących popularności koreanistyki w Polsce są zarówno cywilizacja koreańska, tradycja, obyczaje, wartości, jak i koreańska muzyka popularna, nazywana K-popem, seriale (K-dramy), koreańskie filmy czy taekwondo (narodowy sport Korei). Autorka wskazuje, że zapotrzebowanie na ekspertów spraw koreańskich, tłumaczy jest bardzo duże. Wynika to ze wzrastających relacji biznesowych, kulturowych i naukowych między Polską, UE a Republiką Korei.

Dariusz Jędrasiak próbuje zbadać, w jaki sposób współpraca międzynarodowa w zakresie oświaty, dyplomacja edukacyjna wpływa na wzajemną percepcję Polski i Japonii odpowiednio w obydwu państwach. Autor dokonał w tym zakresie badań empirycznych i na ich podstawie sformułował wnioski. Po pierwsze, podkreślił, że jeśli chodzi o strukturę kontaktów polsko-japońskich na poziomie szkół średnich, ich zasięg, charakter, częstotliwość są realizowane w wąskim zakresie. Po drugie, badacz podkreśla, że mimo tych ograniczeń, wzrasta zainteresowanie Japonią i państwami Azji Wschodniej wśród młodzieży w Polsce. Trzeba 
także podkreślić, że jednocześnie mamy do czynienia z coraz aktywniejszą działalnością rządu Japonii, zmierzającą do rozwoju współpracy z państwami europejskimi. W lutym 2019 r. weszła w życie umowa między UE i Japonią (Economic Partnership Agreement), która otwiera nowe możliwości dla rozwoju relacji gospodarczych między Japonią i UE. Z pewnością czynnik ten także będzie impulsem do rozwijania współpracy naukowej i edukacyjnej oraz, co najważniejsze, jej instytucjonalizacji.

Beata Pietkiewicz-Pareek omawia kwestię nauczania zdalnego w Indiach w okresie pandemii Covid-19. Badaczka skupiła się przede wszystkim na najbiedniejszych regionach Indii. Przedstawiła wdrażane przez władze procedury i ich operacjonalizację.

Renata Ziobro omawia znaczenie terminu Hell Joseon. Badaczka omawia problematykę specyfiki społeczeństwa Republiki Korei. Odwołuje się przy tym do znaczenia tradycji, neokonfucjanizmu w kształtowaniu współczesnego społeczeństwa koreańskiego. Autorka jednoznacznie podkreśla, że termin Hell Joseon nie jest jedynie powszechnym w języku zwrotem, ale autentycznym zjawiskiem społecznym, wyzwaniem.

Aleksandra Kobylańska zwraca uwagę, że dokonując badań nad kwestiami społecznymi Japonii wciąż zbyt mało koncentruje się uwagi na zmianach, jakie dokonują się we współczesnym życiu Japończyków. Artykuł przybliża w tym kontekście jedno ze zjawisk kulturowych kreowanych obecnie przez japońską młodzież. Swoim zachowaniem podkreśla ona, że nie chce być częścią społeczeństwa, w którym najwyższymi wartościami są uniformizacja, hierarchia oraz dyscyplina.

Iwona Grodź dokonuje zaś analizy synergii kultury Wschodu i Zachodu na przykładzie filmu pt. Ran z 1985 r. japoń- 
skiego reżysera Akira Kurosawy. Celem artykułu jest wskazanie inspiracji Kurosawy sztuką Zachodu, które mieszczą się w sferze dialogu międzykulturowego oraz związków teraźniejszości z przeszłością. Badaczka próbuje wskazać na cienką granicę między afirmacją a oporem wobec tradycji rodzimej, po której jak wskazuje I. Grodź „poruszał się” twórca Pijanego anioła.

Dorota Kamińska-Jones omawia problematykę tradycji i współczesności w kulturze indyjskiej na przykładzie świata urody kobiety. Pierwsza część artykułu koncentruje się na perspektywie historycznej, w drugiej zaś przedstawiono ewolucję ideału piękna w czasach współczesnych w Indiach. Jednocześnie badaczka porusza także kwestię przemysłu kosmetycznego, wskazując na znaczącą w ostatnich latach zmianę: od fascynacji produktami zachodnimi do stopniowego powrotu do własnych tradycji, szczególnie Ajurwedy.

Autorzy tekstów w swoich publikacjach odwoływali się zarówno do źródeł pierwotnych, jak i wtórnych. W przedstawianych badaniach w większości odwoływano się do metod jakościowych, analizy dyskursu i studium przypadku. Część badań oparta jest na badaniach empirycznych, wywiadach.

Przygotowana publikacja ma na celu poszerzyć literaturę przedmiotu w zakresie problematyki azjatyckiej. Jest to istotne z kilku powodów. Po pierwsze, od lat 90. XX w. rozwijają się w Polsce studia nad współczesną Azją oraz badania dotyczące relacji państw europejskich z azjatyckimi. Jednym z jego przejawów był dynamiczny rozwój badań i dydaktyki, zwłaszcza w ostatnich 10 latach, dotyczącej studiów nad współczesną Azją. Podejmuje się analizy z zakresu zarówno nauki o stosunkach międzynarodowych, jak i nauk ekonomicznych poświęconych regionowi Azji i Pa- 
cyfiku. Jednym z kluczowych przedmiotów badań oraz dydaktyki oferowanych w ramach studiów azjatyckich stały się zagadnienia dotyczące aspektów kulturowych i społecznych polityki wewnętrznej czy zagranicznej państw Azji. Ponadto w Polsce, ale także w Europie wciąż mamy do czynienia z deficytem wiedzy na temat współczesnej Azji, zwłaszcza w kontekście zmian społecznych, znaczenie kultury dla współczesnego biznesu i polityki. Wydaje się, że zwrócenie uwagi na te zagadnienia umożliwi lepsze zrozumienie specyfiki państw azjatyckich.

Joanna Marszałek-Kawa Jakub Zajączkowski 



\section{Robert Jakimowicz}

Uniwersytet Ekonomiczny w Krakowie

ORCID ID: https://orcid.org/0000-0002-7330-8028

\section{Współczesne stosunki rosyjsko-indyjskie: aspekty polityczne, militarne i gospodarcze}

\section{Wprowadzenie}

W dniu 3 lipca 1947 r. został uchwalony projekt ustawy O przekazaniu władzy w Indiach przez Wielką Brytanię. Jednak przekazanie władzy zostało uzależnione od wstąpienia Indii do Brytyjskiej Wspólnoty Narodów w charakterze dominium, przy jednoczesnym podziale jego terytorium na dwa państwa: hinduistyczne Indie i muzułmański Pakistan ${ }^{1}$ (zachodni i wschodni; w 1971 r. po wojnie domowej wschodnia część stała się niezależnym państwem pod nazwą Bangladesz). Dnia 15 sierpnia 1947 r. została proklamowana niepodległość państwowa Indii. Natomiast w kwietniu 1949 r. na konferencji premierów państw Brytyjskiej Wspólnoty Narodów w Londynie osiągnięto porozumienie w sprawie proklamowania Indii jako suwerennej i niezależnej republiki zachowującej członkostwo we Wspólnocie. W związku z tym 26 listopada 1949 r. została uchwalona nowa Konstytucja, w której Indie proklamowano republiką. Konstytucja weszła w życie 26 stycznia następnego roku. Dzień ten ogłoszono jak święto Dnia Republiki²

1 M.A. Charłamowa, W.S. Siemionowa (red.), Historia dyplomacji od 1945 r., t. 5, cz. 1, Warszawa 1980, s. 193-194.

2 Ibidem. 
Już 13 kwietnia 1947 r. Indie nawiązały stosunki dyplomatyczne ze Związkiem Radzieckim ${ }^{3}$. Pierwszym premierem Indii został Jawaharlal Nehru (15 sierpień 1947-27 maja 1964 r.). Prowadził on politykę niezaangażowania, która spotkała się z pełnym poparciem ZSRR, ponieważ była dopasowana do radzieckiej strategii ograniczania wpływu Stanów Zjednoczonych zarówno w Azji, jak i w Afryce. Strategia ta warunkowała radziecką pomoc rozwojową i wojskową dla Indii w latach 50. i 60. XX w. Podobnie było w kolejnej dekadzie lat 70., kiedy New Delhi uzyskało publiczne poparcie Moskwy dla przeprowadzonych przez nie pierwszych testów jądrowych, którym Stany Zjednoczone były przeciwne, co oczywiście zrodziło napięcie na linii Waszyngton - New Delhi. Należy zauważyć, że Związek Radziecki z jednej strony publicznie podkreślał ich pokojowy charakter, natomiast $\mathrm{z}$ drugiej próbował nieoficjalnie przekonać partnera o ich niekontynuowaniu ${ }^{4}$. W tym miejscu należy dodać, że od $1975 \mathrm{r}$. z powodu wspomnianych testów jądrowych Grupa Nuklearnych Dostawców (NSG - The Nuclear Suppliers Group), obejmująca wszystkie ważne nuklearne kraje dostawcze, skutecznie zakazała eksportu obiektów nuklearnych do Indii. ${ }^{5}$

Inną ważną przesłanką, z której wynikało poparcie Moskwy dla Indii była wizja premiera Nehru, w której postrze-

3 Kundu Nivedita Das, India's Strategic Cooperation with Russia and its 'Near Abroad' States, „India Quarterly”, październik 2008, vol. 64, nr 4, s. 74; Аипломатические отношения СССР, [w:] Аипломатический словарь А-И, t. 1, Москва 1984, s. 313.

4 E. Tamkin, Why India and Russia Are Going to Stay Friends. Conventional wisdom holds that New Delhi will turn to Washington as it increases competition with Beijing. But Moscow's importance cannot be ignored, 8.07.2020, https://foreignpolicy.com/2020/07/08/russia-india-relations/ [dostęp: 31.07.2020].

5 S. Thomas, Russia's Nuclear Export Programme, „Energy Policy” 2018, nr 121, s. 239. 
gał swój kraj jako niekapitalistyczny i przynajmniej częściowo socjalistyczny.

Między innymi z przytoczonych przesłanek wynikało niezmiennie poparcie strony radzieckiej (rosyjskiej) od lat 50. XX w. po dzień dzisiejszy w sprawie sporu o Kaszmir. Związek Radziecki był jedynym państwem, które zawetował rezolucje w sprawie interwencji ONZ w Kaszmirze w latach 1957, 1962 i 1971.

Innym wyrazem zacieśniania więzów pomiędzy obu państwami była sprzedaż radzieckiej broni i technologii wojskowej partnerowi indyjskiemu. W $1964 \mathrm{r}$. zostało podpisane między nimi porozumienie na temat transferu technologii obronnej, uzależniając głębiej Indie od Moskwy i powiększenie przez Związek Radziecki „skali dostarczanej zaawansowanej broni Indiom". W latach 1965-1969 80\% całości importowanego sprzętu wojskowego przez New Delhi pochodziło od partnera radzieckiego ${ }^{6}$.

Dekady lat 70. i 80. charakteryzowały się również intensywnym importem radzieckiego uzbrojenia obronnego przez Indie. Niewątpliwie ich formalną podstawą było podpisanie przez oba państwa 9 sierpnia 1971 r. w New Delhi, ze strony indyjskiej przez ministra spraw zagranicznych Swarana Singha, radzieckiej przez ministra spraw zagranicznych Andrieja Gromykę, traktatu o pokoju, przyjaźni i współpracy ${ }^{7}$. W traktacie tym każda ze stron oświadczyła m.in., że „nie będzie wstępować lub uczestniczyć w sojuszach wojskowych, skierowanych przeciwko drugiej stronie i wstrzymuje się od

6 B. Gogoi, Military-Technical Collaboration Between India and Russia: An Overview of the Post-Soviet Period, „India Quarterly”, lipiec 2002, vol. 38, nr 3-4, s. 304 .

7 Совместное заявление 1971 об офиц. визите в Индию министра иностр. дел СССР А.А. Громько (8-12 VIII), [w:] Аипломатический словарь С-Я, t. 3, Москва 1986, s. 160. 
agresji przeciwko niej i nie dopuszcza wykorzystania swojego terytorium dla dokonania jakiegokolwiek aktu, który mógłby przynieść jej wojskowy (wojenny) uszczerbek. ZSRR i Indie zobowiązały się także powstrzymywać od udzielania pomocy każdej trzeciej stronie, uczestniczącej w zbrojnym konflikcie z drugą stroną"

Pogłębieniem ówczesnego radziecko-indyjskiego partnerstwa strategicznego była dalsza współpraca obronna, której przykładem było m.in. porozumienie o zakupie broni przez Indie w maju 1980 r., którego wartość wyniosła około 1,6 mld USD. Zakup ten był na preferencyjnych warunkach $-2,5 \%$ odsetek. W jego ramach Indie otrzymały m.in. MiG-23s czy wersję rozpoznawczą Mi-25. W sumie, w latach 1960-1990 wartość dostarczonego przez ZSRR sprzętu wojskowego Indiom wyniosła 35 mld USD'.

Ważną dziedziną współpracy były: sektor energetyki i eksploracja kosmosu. W listopadzie 1988 r. oba państwa podpisały porozumienia dotyczące budowy elektrowni atomowej w Indiach o mocy 2 x 1000 MW. Jednak zamówienie nie zostało zrealizowane $\mathrm{z}$ powodu upadku ZSRR ${ }^{10}$. Zostało ono wprowadzone w życie w 1998 r., budowa rozpoczęła się w 2002 r. W 2013 r. pierwsza jednostka rozpoczęła produkcję, a druga natomiast została podłączona do sieci w sierpniu 2016 r. ${ }^{11} \mathrm{~W}$ przypadku eksploracji kosmosu uwagę zwracają dwa wydarzenia. Wspieranie przez Związek Radziecki Indii

8 Аоговор 1971 о мире, дружбе и сотрудничестве подписан 9 VIII в Аели, [w:], Аипломатический словарь С-Я, t. 3, Москва 1986, s. $165-166$.

9 Kundu Nivedita Das, India's Strategic Cooperation with Russia..., op.cit., s. 75.

10 T. Steve, Russia's Nuclear Export Programme, „Energy Policy” 2018, nr 121, s. 240.

11 Ibidem. 
w tworzeniu Równikowej Stacji Wyrzutni Rakiet Thumba (the Thumba Equatorial Rocket Luaunching Station) i w wystrzeliwaniu eksperymentalnych satelit Aryabhatta i Bhaskara 1 i 2 oraz lot indyjskiego pioniera kosmonautyki lidera eskadry Rakesha Sharmy na Stację Kosmiczną Salut ${ }^{12}$. Na marginesie należy podkreślić, że w 1975 r. na orbicie został umieszczony pierwszy indyjski satelita - Aryabhat, który został wyniesiony za pomocą radzieckiej rakiety nośnej. Natomiast w 1980 r. Indiom udało się skonstruować własną rakietę nośną, dzięki której uzyskały one samodzielność umieszczania obiektów w kosmosie, co nie oznaczało zarzucenia dalszej współpracy kosmicznej z Moskwą ${ }^{13}$.

Celem tego artykułu jest próba dokonania analizy rozwoju rosyjsko-indyjskich stosunków w trzech aspektach: politycznym, gospodarczym i wojskowym po upadku Związku Radzieckiego, z którego wyłoniło się piętnaście niepodległych państw, w tym Federacja Rosyjska. Analiza ta powinna umożliwić odpowiedzi na następujące pytania. Po pierwsze, jakie znaczenie miały byłe relacje radziecko-indyjskie na utrzymanie wzajemnych przyjacielskich relacji? Po drugie, jak w polityce zagranicznej oba państwa postrzegają się wzajemnie i czy następowała ewolucja tego postrzegania? Po trzecie, czy współpraca wojskowa między obu państwami, w stosunku do poprzedniego okresu radziecko-indyjskiego zmieniła swój charakter i jakie ma znaczenie obecnie? Po czwarte, jak rozwijają się relacje gospodarcze obu państw, jakie mają dla nich znaczenie i jakie są ewentualnie ich perspektywy? W ni-

12 Kundu Nivedita Das, India's Strategic Cooperation with Russia..., op.cit., s. 75-76.

13 N. Olszanecka, Rosyjsko-indyjska wspótpraca $w$ dziedzinie nauki i eksploracji kosmosu, „Historia i Polityka” 2016, nr 15, s. 113, http:// dx.doi.org/10.12775/HiP.2016.006 [dostęp: 29.12.2020]. 
niejszym artykule wykorzystano analizę porównawczą i systemową oraz metodę krytycznej analizy.

Struktura artykułu sprowadza się do podziału na trzy zasadnicze części: aspektów politycznych, aspektów gospodarczych oraz aspektów militarnych. W pierwszej części autor koncentruje się na ewolucji stosunków politycznych, które w zasadzie sprowadzają się do dwóch etapów - okresu prezydentury Borysa Jelcyna i prezydentury Władimira Putina oraz krótkiego okresu prezydentury Dimitrija Miedwiediewa. W drugiej części analizowane są rosyjsko-indyjskie obroty handlowe i ich struktura, wielkości inwestycji. W trzeciej części badano ewolucję jakościową współpracy militarnej.

\section{Aspekty polityczne}

Po upadku Związku Radzieckiego Federacja Rosyjska, jako jego sukcesorka, odnowiła radziecko-indyjski traktat o pokoju i przyjaźni z 1971 r., podpisując nowy traktat o przyjaźni i współpracy z partnerem indyjskim ważny dwadzieścia lat. Wydarzenie to miało miejsce podczas wizyty prezydenta Federacji Rosyjskiej Borysa Jelcyna w Indiach, w dniach 2729 stycznia 1993 r. ${ }^{14}$ Poza podpisaniem nowego traktatu ważnym wydarzeniem w trakcie wizyty rosyjskiego prezydenta było uregulowanie sprawy indyjskiego zadłużenia, zagwarantowanie dostaw rosyjskiej broni konwencjonalnej oraz zwiększonych dostaw ropy naftowej ${ }^{15}$. Natomiast w czerwcu $1994 \mathrm{r}$.

14 D.A. Mahapatra, Indo-Russian Economic Cooperation: Surmounting the Rupee-Reactor Syndrom, "India Quarterly”, październik 2007, vol. 63, nr 4, s. 106.

15 J. Zajączkowski, Indie w stosunkach międzynarodowych, Warszawa 2008, s. 224. 
doszło do wizyty premiera Pamulaparti Venkata Narasimha Rao, która usytuowała stosunki indyjsko-rosyjskie na solidnej podstawie. W trakcie wizyty została podpisana Deklaracja moskiewska na temat ochrony interesów państw pluralistycznych, która koncentrowała się na wzroście niemilitarnych zagrożeń dla integralności terytorialnej obu państw. Wskazano na zagrożenia ze strony sił religijnego ekstremizmu, separatyzmu, konfliktów etnicznych i terroryzmu ${ }^{16}$. Obie strony zobowiązały się w niej do wzajemnego wspierania integralności terytorialnej. Duży niepokój w obu państwach budziło zdobycie przez talibów władzy w znaczącej większości Afganistanu i tym samym rozprzestrzeniania idei mediewistycznego wariantu islamu, który trafiał do islamistycznych fundamentalistów w państwach Azji Centralnej, Pakistanie, jak i na terenie niektórych stanów Indii i Federacji Rosyjskiej. Niemniejsze znaczenie miała podpisana w trakcie tej wizyty Deklaracja na temat dalszego rozwoju i uwydatniania współpracy. Także został podpisany Traktat o ekstradycji ${ }^{17}$.

W grudniu 1994 r. przybył do Indii rosyjski premier Wiktor Czernomyrdin. Ważnym aspektem tej wizyty było odrzucenie spekulacji i zapewnienie indyjskiego kierownictwa o niedostarczaniu broni do Pakistanu ${ }^{18}$.

W powyższym kontekście wizyty indyjskiego premiera Deve Gowdy w Rosji naturalne było podkreślenie przez niego strategicznego partnerstwa obu państw ${ }^{19}$.

16 N. Joshi, India and Russia: enduring partnership, „India Quarterly", lipiec-grudzień 2002, vol. 58, nr 3-4, s, 115.

17 Ibidem, s. 115-116.

18 D.A. Mahapatra, Indo-Russian Economic Cooperation: Surmounting..., op.cit., s. 106-107.

19 J. Zajączkowski, Indie w stosunkach międzynarodowych..., op.cit., s. 225 . 
Niemniej jednak przez większą część lat 90. XX w. Rosja bardziej była zainteresowana realizacją polityki prozachodniej, niż rozwijaniem specjalnych stosunków z Indiami, co wynikało z kryzysu gospodarczego państwa rosyjskiego i oczekiwań Moskwy na uzyskanie wymiernej pomocy gospodarczej ze strony Zachodu. Odzwierciedleniem tego kryzysu był m.in. spadek PKB per capita. O ile w $1990 \mathrm{r}$. PKB per capita ZSRR wynosił 6700 USD, o tyle w Federacji Rosyjskiej, na skutek m.in. nieudolnych reform per capita w 1999 r. wynosiło jedynie 1260 USD. Budżet państwa radzieckiego w 1990 r. wynosił 600 mld USD, a budżet państwa rosyjskiego w 1999 r. wyniósł 20 mld USD. Ponadto rozpad Związku Radzieckiego i oddzielenie się niepodległych państw oznaczały dla Rosji utratę około $50 \%$ ludności, $25 \%$ terytorium i $70 \%$ potencjału produkcyjnego ${ }^{20}$. Jednak po pierwszej połowie ostatniej dekady XX w. zrodziło się ogromne rozczarowanie Rosji wobec Zachodu, które zaowocowało pojawieniem się w polityce rosyjskiej wektora wschodniego. Jego zwolennikiem i realizatorem był rosyjski minister spraw zagranicznych (10 styczeń 1996-11 wrzesień 1998 r.) i późniejszy premier (11 wrzesień 1998-12 maj 1999 r.) Jewgienij Primakow. Tym samym Indie ponownie znalazły się w polu zainteresowania Moskwy, co wyraziło się w bardziej intensywnym rozwojem wzajemnych stosunków. W 1998 r. została podpisana wspólna deklaracja rosyjsko-indyjska, w której Moskwa uznała Indie za „wpływowego uczestnika stosunków międzynarodowych, za silnego i odpowiedzialnego kandydata do stałego miejsca w rozszerzo-

20 R. Jakimowicz, Geostrategiczny wybór Rosji u zarania trzeciego tysiaclecia, t. III, Polityka Federacji Rosyjskiej wobec regionu Azji i Pacyfiku, Azji Centralnej i Arktyki, Kraków 2015, s. 291. 
nej Radzie Bezpieczeństwa ONZ"21. Tym samym Rosja jako pierwsze wielkie mocarstwo, poparła stałe członkostwo Indii w Radzie Bezpieczeństwa. Poparcie to wynikało z kalkulacji Moskwy, że razem z Chinami i Indiami będzie mogła na forum Rady Bezpieczeństwa stanowić przeciwwagę dla jednostronnych działań Stanów Zjednoczonych. Koncepcja równowagi sił była również popierana przez Indie, co zbliżało do siebie New Delhi i Moskwę 22 .

Indie na przełomie wieków były postrzegane jako ważny partner strategiczny. Wyrazem tego była wizyta nowego prezydenta Federacji Rosyjskiej, Władimira Putina, w Indiach w październiku 2000 r., w trakcie której obie strony podpisały Deklarację o strategicznym partnerstwie i zawarły wiele transakcji związanych ze współpracą wojskową ${ }^{23}$. Według Deklaracji o strategicznym partnerstwie zostało stworzonych kilka zinstytucjonalizowanych mechanizmów dialogu, które działają na poziomach politycznym i oficjalnym i zapewniają regularne wzajemne relacje w kolejnych latach. W tym miejscu należy podkreślić, że prezydent Władimir Putin i premier Atal Bihari Vajpayee rozpoczęli tym spotkaniem proces corocznych szczytów między liderami obu państw, który jest jednym z najważniejszych zinstytucjonalizowanych mechanizmów dialogu. Tym samym premier Vajpayee odbył swój pierwszy szczyt w Moskwie w 2001 r. We wspomnianej deklaracji o strategicznym partnerstwa podkreślono m.in., że „istnieje konieczność do budowania wielobiegunowej struktury światowej opartej na suwerennej równości wszystkich

21 J. Zajączkowski, Indie w stosunkach..., op.cit., s. 226, za: Indo-Russian Presss Treatement, 22.12.1998, New Delhi, http://www.indian-embassy.org/pic/PR_1998/December98/prdec2298.html [dostęp: 29.12.2020].

22 Ibidem.

23 J. Zajączkowski, Indie w stosunkach..., op.cit., s. 225. 
państw i narodów, demokratycznych wartości i sprawiedliwości” oraz, że „deklaracja zapewnia wspólne inicjatywy w kluczowych sprawach międzynarodowych i wzajemnym informowaniu się o planowanych inicjatywach polityki zagranicznej na międzynarodowej arenie". Także zapewniono w niej, że strony „nie będą uczestniczyć w żadnych wojskowych, politycznych lub innych sojuszach lub innych związkach (stowarzyszeniach) lub konfliktach zbrojnych bezpośrednio wymierzonych w drugą stronę lub w jakichkolwiek traktatach, porozumieniach lub umowach naruszających niepodległość, suwerenność, integralność terytorialną lub narodowe interesy bezpieczeństwa drugiej strony" ${ }^{24}$.

Podczas wizyty prezydenta Putina w Indiach, 4 grudnia 2002 r., została podpisana deklaracja delhijska na temat dalszej konsolidacji strategicznego partnerstwa pomiędzy obu $\mathrm{krajami}^{25}$. W następnym roku, 12 listopada, podczas wizyty premiera Vajpayee w Moskwie podpisano Deklarację na temat globalnych wyzwań i zagrożeń dla międzynarodowego bezpieczeństwa i stabilizacji. W deklaracji położono nacisk na wielostronność przeciwko jednostronności w sprawach światowych ${ }^{26}$.

Kolejnym wyrazem zacieśniających się obustronnych więzi stała się także deklaracja z grudnia 2003 r., w której oba państwa zobowiązały się do nieuczestniczenia w skierowanych przeciwko sobie sojuszach. We wspólnej deklaracji, z grudnia 2004 r., prezydent Władimir Putin i premier Manmohan Singh podkreślili, że strategiczne partnerstwo służy ich długoterminowym interesom narodowym, wzmac-

24 B. Thomas, Putin's India Policy: Mutual Gains for Future, „India Quarterly", kwiecień-czerwiec 2007, vol. 63, nr 2, s. 136-137.

25 Ibidem.

26 Ibidem. 
nia wzajemne stosunki dwustronne oraz pogłębia wzajemnie korzystną współpracę i przyczynia się do międzynarodowego pokoju i bezpieczeństwa. Przyczyniać się do tego miała intensyfikacja wymian w stosunkach dwustronnych na poziomach politycznym i parlamentarnym oraz pomiędzy Radami Bezpieczeństwa na oficjalnym poziomie. Ponadto obaj przywódcy zwrócili m.in. uwagę na znaczenie działania Wspólnej Grupy Roboczej do spraw Zwalczania Międzynarodowego Terroryzmu ${ }^{27}$. W deklaracji Indie poparły akcesję Rosji do Światowej Organizacji Handlu (WTO). Natomiast po raz kolejny Federacja Rosyjska potwierdziła swoje poparcie dla kandydatury Indii na stałego członka w rozszerzonej Radzie Bezpieczeństwa NZ28. Dalej obie strony odnotowały z satysfakcją regularne odbywanie się trójstronnych spotkań na poziomie ministrów spraw zagranicznych Rosji, Indii i Chin ${ }^{29}$.

Także intensywny dialog między obu państwami wpłynął na polepszenie stosunków indyjsko-chińskich, którego wyrazem były wspomniane spotkania ministrów zagranicznych Rosji, Indii i ChRL, z których kolejne odbyło się w czerwcu 2005 r. ${ }^{30}$ Część analityków uznała to spotkanie za powrót do idei Jewgienija Primakowa z 1998 r., która dotyczyła „budowy strategicznego trójkąta New Delhi-Moskwa-Pekin" ${ }^{31}$. Nie-

27 Joint declaration by the Russian Federation and the Republic of India 3 December 2004, http://rusembindia.com/russia-india-dialogue-and-official-documents/.../120-official-documents/1760-joint-declaration-by-the-russian-federation-and-the-republic-of-india [dostęp: 1.07.2018].

28 Ibidem.

29 Ibidem.

30 S. Prakash, Contemporary India-China-Russia Relations: Dimensions of a New World Order, „India Quarterly”, lipiec-wrzesień 2005, nr 3, s. 28. Szerzej na temat relacji w trójkącie Indie-Chiny-Rosja; ibidem, s. $28-47$.

31 J. Zajączkowski, Indie w stosunkach..., op.cit., s. 22, 227. 
mniej jednak trzeba podkreślić, że celem wzajemnych relacji trzech państw nie było stworzenie strategicznego trójkąta, jaki był formalnie zaproponowany przez premiera Jewgienija Primakowa w 1998 r. w trakcie jego wizyty w Indiach, ponieważ te trzy państwa były zainteresowane w utrzymywaniu bliskich relacji ze Stanami Zjednoczonymi. Jeśli Rosja, Indie i Chiny były autentycznie zjednoczone w tworzeniu świata wielobiegunowego, siła ich partnerstwa mogła być wystarczająca do powstrzymywania Stanów Zjednoczonych, do podejmowania jednostronnych działań w obszarze międzynarodowym ${ }^{32}$. Pomimo tego, że Rosja znormalizowała swoje stosunki z Chinami, wciąż dostrzegała zagrożenie z ich strony na Dalekim Wschodzie w formie migracji ludności i roszczeń terytorialnych. Ponadto Wschodnia Syberia jest bogata w surowce energetyczne, których tak potrzebuje ChRL ${ }^{33}$.

Ważnym spoiwem łączącym Rosję, Chiny i Indie, w trakcie toczącej się wówczas wojny z terroryzmem, było zapobieganie wzrostowi fundamentalizmu islamskiego w regionie ${ }^{34}$. Do trójstronnego spotkania na szczycie doszło w lipcu 2006 r. w Sankt Petersburgu. Podkreślono na nim, że trójstronne relacje promują rozwój wzajemnie korzystnej współpracy gospodarczej między Rosją, Indiami i Chinami, akcentując międzynarodową zgodę na polu przeciwdziałania nowym wyzwaniom i zagrożeniom, szczególnie w walce przeciwko terroryzmowi ${ }^{35}$.

32 B. Thomas, Putin's India Policy: Mutual Gains for, op.cit., s. 127-128 .

33 Ibidem, s. 124.

34 J. Zajączkowski, Indie w stosunkach..., op.cit., s. 22, 227.

35 Joint Statement on the outcome of the Official Visit of H.E. Mr. Vladimir V. Putin, President of the Russian Federation to the Republic of India January 25, 2007. Category: Official Documents, 25.01.2007, http://Official-Documents-1759-joint-statement-on-the-official-visit- 
W dniach 25-26 stycznia 2007 r. prezydent Putin złożył oficjalną wizytę w Indiach na zaproszenie premiera Manmohana Singha. Symbolem tej wizyty był fakt, że prezydent Rosji został zaproszony na diamentowy jubileusz roku niepodległości Indii jako główny gość. Tym samym był pierwszym rosyjskim liderem uczestniczącym w głównych obchodach jako gość honorowy ${ }^{36}$. W trakcie wizyty zostało podpisanych jedenaście głównych porozumień bilateralnych. Dotyczyły one wspólnej współpracy gospodarczej i technicznej na takich polach, jak: przestrzeń kosmiczna, przemysł obronny, sektor energetyczny, elektrownie jądrowe, inwestycje i nauka, dalsza współpraca w budowie maszyn, metale żelazne i nieżelazne, budowa mieszkań, portów, dróg i innych sieci infrastrukturalnych itd. ${ }^{37}$ Ponadto podpisany został przez liderów m.in. Program o wymianie kulturalnej na lata 2007-2009, protokół dotyczący organizacji obchodów „Roku Rosji” w Indiach w 2008 r. i „Roku Indii” w Rosji w 2009 r. ${ }^{38}$ W oświadczeniu wyraźnie podkreślono kontynuowanie współpracy na polu pokojowego wykorzystania energii atomowej. Wśród osiągniętych porozumień znalazło się porozumienie o dostępie strony indyjskiej do części Rosyjskiego Globalnego Systemu Nawigacji Satelitarnej GLONNAS (the

of-the-mr-Vladimir-v-putin-president-of-the-Republic-of-India-January-25-2007 [dostęp: 1.07.2018].

36 K. Budhwar Prem, India-Russia Relations Past, Present and the Future, „India Quarterly”, lipiec 2007, vol. 63, nr 3, s. 70.

37 Ibidem, s. 70-71.

38 Kundu Nivedita Das, India's Strategic Cooperation with Russia..., op.cit., s. 83; Joint Statement on the outcome of the Official Visit of H.E. Mr. Vladimir V. Putin, President of the Russian Federation to the Republic of India January 25, Category: Official Documents, 25.01.2007, http://Official-Documents-1759-joint-statement-on-the-official-visit-of-the-mrvladimir-v-putin-president-of-the-Republic-of-India-January-25-2007 [dostęp: 1.07.2020]. 
Russian Global Navigation Satellite System) oraz porozumienie na temat współpracy we wspólnym projekcie satelity „YouthSat”, którego autorami była Rosyjska Federalna Agencja Kosmiczna i Indyjska Organizacja Badań Kosmicznych $(\text { ISRO })^{39}$.

W dniach 4-6 grudnia 2008 r. prezydent Federacji Rosyjskiej Dimitri Miedwiediew udał się z wizytą do Indii, w trakcie której podkreślił, że Indie oraz Chiny są kluczowymi partnerami Rosji w kształtowaniu się nowego światowego systemu finansowego i architektury bezpieczeństwa. Ważnym efektem wizyty rosyjskiego prezydenta było podpisanie porozumienia dotyczącego budowy czterech dodatkowych reaktorów w elektrowni atomowej Kudankulam w Tamil Nadu. Także postanowiono zrealizować porozumienie z lutego tego roku, na dostarczenie rosyjskiego paliwa nuklearnego do elektrowni atomowej partnera. W tym miejscu należy podkreślić, że w pierwszej dekadzie obecnego wieku rosyjsko-indyjska współpraca gospodarcza ograniczała się głównie do trzech sektorów: broni i zbrojeń obejmujących transfer broni, wspólnego rozwoju i projektowania, przestrzeni kosmicznej i energii nuklearnej ${ }^{40}$.

W dniach 2-4 września 2009 r., w trakcie obchodów „Roku Indii” w Rosji z państwową wizytą do Moskwy przybył prezydent Republiki Indii Pratibha Patil. Obaj przywódcy omówili m.in. poglądy na temat priorytetów rosyjsko-indyjskich stosunków dotyczących sektorów energetycznego, metalurgicznego, budowy maszyn, przemysłów o dużym wkła-

39 Joint Statement on the outcome of the Official Visit of H.E. Mr. Vladimir V. Putin, President of the Russian Federation to the Republic of India January 25, Category: Official Documents, 25.01.2007..., op.cit. [dostęp: 10.07.2020].

40 D.A. Mahapatra, Indo-Russian Economic Cooperation: Surmounting..., op.cit., s. 108-109. 
dzie wiedzy oraz transporcie i bankowości. Ze swej strony prezydent Miedwiediew podkreślił, że rozwój stosunków rosyjsko-indyjskich pozostanie jako jeden z priorytetów polityki zagranicznej Rosji ${ }^{41}$.

W kolejnym 2010 r., w dniach 20-22 grudnia, udał się z oficjalną wizytą do Indii prezydent Dimitri Miedwiediew. Efektem wizyty było podpisanie przez obie strony trzydziestu dokumentów. Wśród nich był Protokół ustaleń na temat współpracy badawczej i technologicznej w pokojowym wykorzystaniu energii nuklearnej (odniesiono się także do tzw. „Mapy drogowej dla serii budowy zaprojektowanych rosyjskich elektrowni atomowych w Republice Indii" - w skrócie - „Mapa Drogowa” z 12 marca 2010 r.), kontrakt na model myśliwca piątej generacji oraz porozumienie na temat złagodzenia wymagań wizowych dla pewnej kategorii obywateli. Prezydent Miedwiediew w trakcie trzech dni spotkał się z prezydentem i wiceprezydentem Indii, Pratibha Patilem i Shri Mohammadem Hamid Ansarim, ministrem spraw zagranicznych Somanahalli Mallaiah Krishną i wielu innymi politykami. W trakcie spotkania ze studentami prezydent Miedwiediew zapewnił, że Rosja jest gotowa pomóc Indiom walczyć z terroryzmem, dostarczając im broń i technologie oraz przeprowadzać regularne odbywanie ćwiczeń wojskowych. Podkreślił stałą gotowość Rosji do rozszerzenia współpracy z partnerem indyjskim w dziedzinie obrony i bezpieczeństwa ${ }^{42}$.

41 State visit of the President of the Republic of India Pratibha Patil to Russia. September 2-6, 2009. Category: Visits and summits, 6.09.2009, http://resembind.com/visits-and-summits/1774-state...2-6-2009?tmpl=componente-format=pdf [dostęp: 1.07.2018].

42 Russian President Dmitry Medvedev is on and official visit to India on December 20-22, during which cooperation on trade, economic, energy and cultural issues will be discussed, Category: Visits and Summits, 
Z końcem 2011 r., 15-17 grudnia, oficjalną wizytę w Moskwie złożył premier Manmohan Singh, przyjęty przez prezydenta Miedwiediewa, podczas której podpisano wspólną deklarację na temat kontynuowania umacniania rosyjsko-indyjskiego partnerstwa strategicznego. Ponadto byli świadkami przy podpisywaniu licznych porozumień o współpracy. Na uwagę zasługuje m.in. protokół nr 2 do Międzyrządowego Porozumienia z 3 października 2000 r. na temat dostarczenia technicznej pomocy w organizowaniu produkcji samolotu SU-30MKI. Obali liderzy spotkali się później z rosyjskimi i indyjskimi przedstawicielami środowiska biznesu ${ }^{43}$.

W latach 2011-2012 dojrzewała decyzja dalszego podnoszenia rangi strategicznego partnerstwa na poziomie „specjalnego i uprzywilejowanego partnerstwa”. Oznaczało to konsekwentną instytucjonalizację mechanizmu dialogu. Jednym z jego ważnych elementów były coroczne spotkania na szczycie pomiędzy premierem Indii i prezydentem Federacji Rosyjskiej. W 2012 r., od deklaracji strategicznego partnerstwa, miało miejsce już trzynaście spotkanie na szczycie. Doszło do niego 24 grudnia tego roku, w New Delhi, pomiędzy prezydentem Władimirem Putinem i premierem Manmohanem Singhiem. Partnerzy w wydanym oświadcze-

23.12.2010, https://rusemdbinda.com/2118-...21-22-2010-?tmpl=pdf [dostęp: 1.07.2018]; Major deals between India and Russia, New Delhi, December 22, 2010, 23.12.2010, http://rusembindia.com/russia-india-dialogue-en/official-documents/.../120-officialdocuments/2122major-deals-between-india-and-russia-new-delhi-december [dostęp: 1.07.2018].

43 Visit of the Prime Minisster of the Republic of India Manmohan Singh to Moscow, December, 2011, 3.02.2012, http://resembindia.com/ russia-india-dialogue-en/visits-and-summits/.../121-visitsandsummits/3840-visit-of-the-relpublic-of-india-mannohan-singh [dostęp: 1.07.2018]. 
niu dla mediów skoncentrowali się m.in. na promowaniu handlu i inwestycji, pogłębianiu partnerstwa energetycznego, postępu naukowo-technicznego, współpracy technicznej i wojskowej, współpracy w przestrzeni kosmicznej czy rozszerzaniu kontaktów humanitarnych ${ }^{44}$.

W grudniu 2014 r. doszło do spotkania na szczycie między prezydentem Władimirem Putinem i nowym premierem Indii Narendrą Modi. Obaj liderzy na konferencji prasowej obszernie przedstawili przebieg rozmów pomiędzy nimi. Premier Modi podkreślił, że w rozmowach zostały poruszone kwestie współpracy obronnej, bezpieczeństwa energetycznego, współpracy w pokojowej eksploracji kosmosu, a także bliskiej współpracy w obrębie Narodów Zjednoczonych, BRICS, Szanghajskiej Organizacji Współpracy i innych organizacjach ${ }^{45}$. Premier Modi podziękował prezydentowi Putinowi za jego poparcie dla bliższych stosunków Indii z Euroazjatycką Unią Gospodarczą. W przypadku kwestii współpracy wojskowej Rosja przychyliła się do prośby partnera indyjskiego do zlokalizowania mocy produkcyjnych w Indiach związanych z częściami zamiennymi i komponentami dla rosyjskiego sprzętu defensywnego. Bezpieczeństwo energetyczne miało być kontynuowane przez rozwój pokojowej energetyki jądrowej oraz importu z Federacji Rosyjskiej węglowodorów do Indii, która jest

44 Official visit to India of the President Vladimir Putin, December 24, 2012, 24.12.2012, http://rusembindia.com/russia-india-dialogue-en/ visits-and-summits/...december-24-2017?tmpl=component\&format=pdf [dostęp: 1.07.2018].

45 Press statements following Russian-Indian talks, December 11, 2014, 12.12.2014, http://rusembindia.com/Russia-india-dailogue-en/ visits-and-summits/7092-press-statements-following-russian-inadian-talks-december-112014?tmpl=component\&format=pdf [dostęp: 1.07.2018]. 
jednym z największych importerów światowych. Obie strony w tej kwestii podpisały wiele ważnych porozumień. $\mathrm{Na}$ uwagę zasługuje także priorytet we współpracy obu stron, którym jest walka z przestępczością zorganizowaną, terroryzmem i ekstremizmem oraz handlem narkotykami ${ }^{46}$. Ponadto obie strony podkreśliły, że odbędą rozmowy z rosyjskimi i indyjskimi przedstawicielami biznesu i wezmą udział w otwarciu Światowej Konferencji o Diamentach (the World Diamond Conference). Premier Modi ze swej strony zaznaczył, że jest to ważny obszar współpracy, biorąc pod uwagę fakt, że rosyjska firma Alrosa jest obecnie największym producentem diamentów na świecie, podczas gdy Indie są czołowym krajem w obróbce diamentów ${ }^{47}$. W sumie zostało podpisanych czternaście dokumentów międzyrządowych i duża ilość kontraktów handlowych ${ }^{48}$.

Innym ważnym obszarem wzmacniania współpracy podkreślonym przez obu liderów była współpraca międzyregionalna na różnych polach. Już wówczas wiele miast i regionów w obu krajach miało swoje powiązania. W przypadku miast: Moskwa i Sankt Petersburg-New Delhi; Nowosybirsk-Bangalore; Ufa-Chandigarh; Wołgograd-Chennai;

46 Ibidem.

47 Ibidem. Obszernie na temat umacniania indyjskiego partnerstwa w kolejnej dekadzie zob. Joint Statement Druzhba-Dosti: A Vision for strengthening the Indian-Russian Partnership over the next decade. Category: Official Documents, 12.12.2014, http://rusembinda.com/official-documents/7090-joint-statement-druzhba-dosti-a-vision-for-strengthening-the-indian-russian-partnership-over-the-next-decade?tmpl=component\&format=pdf [dostęp: 1.07.2018].

48 List of documents signed during the Official Visit of President of Russian Federation to India, Dec 10-11, 2014, , 13.12.2014, http://resenbinda. com/official-documents/7809-list-of-documents-signed-during-the-offcial-visit-of-president-of-russian-federation-to-India-dec10-11-2014?tm$\mathrm{pl}=$ component\&format=pdf [dostęp: 1.07.2018]. 
Kazań-Hyderabad; Władywostok i Jarosław-Kalkuta; Piatigorsk-Kochi; Sankt Petersburg-Mumbai; Jekaterinburg-Pune; Krasnodar-Panjim; Stawropol-Thiruvanathapuram; Jessentuki-Thrissur. Natomiast w przypadku regionów: Tatarstan-Andhra Pradesh; Astrachań i Tatarstan-Gujarat; Baszkortostan-Haryana; Irkuck-Karnataka; Ugra i Samara-Khanty-Masiysk Okręg Autonomiczny; Irkuck-Kerala; Syberia-Maharashtra ${ }^{49}$.

W 2016 r. Federacja Rosyjska i Indie zgodziły się na Partnerstwo dla Światowego Pokoju i Stabilizacji ${ }^{50}$.

Dzięki zachętom i poparciu Federacji Rosyjskiej Indie zostały pełnoprawnym członkiem Szanghajskiej Organizacji Współpracy w 2017 r. Głównym powodem, którym kierowała się Moskwa było pragnienie zapobieżenia sytuacji, aby organizacja była zdominowana przez Chiny oraz niepokój, że zostanie podzielona przez państwa Azji Centralnej. Chiny, podczas gdy początkowo sprzeciwiały się tej idei, zgodziły się pod warunkiem, że Pakistan także dołączy do tej wielostronnej organizacji ${ }^{51}$. Ponadto Moskwa wyszła z założenia, że członkostwo Indii i Pakistanu w tej organizacji może przyczynić się do normalizacji stosunków indyjsko- pakistańskich ${ }^{52}$.

W dniu 21 maja 2018 r. odbył się pierwszy nieformalny szczyt pomiędzy prezydentem Władimirem Putinem i pre-

49 Joint Statement Druzhba-Dosti: A Vision for strengthening..., op.cit. [dostęp: 1.07.2018].

50 N. Kapoor, India-Russia Ties in a Changing World Order: In Pursuit of a 'Special Strategic Partnership', „ORF Occasional Paper”, październik 2019, nr 218, s. 4.

51 Ibidem, s. 3.

52 T. Shaumyan, The Eurasian factor in Russian foreign policy. Implications for India, [w:] Eurasia and India. Regional Perspectives, red. K. Warikoo, London-New York 2018, s. 97. 
mierem Narendrą Modi w Soczi w Federacji Rosyjskiej. Obaj przywódcy wymienili się poglądami na temat kwestii regionalnych i międzynarodowych. Tego samego roku, w dniach 4-5 października, prezydent Putin udał się z wizytą do New Delhi na już 19. doroczny szczyt dwustronny między obu państwami. Efektem wizyty było podpisanie ośmiu protokołów ustaleń, m.in. w dziedzinie biznesu i inwestycji, cywilnej współpracy nuklearnej, kosmosu i transportu. W tym miejscu na uwagę zasługuje wspólne oświadczenie obu liderów, w którym prezydent Putin wyraził poparcie dla członkostwa Indii w Nuclear Suppliers Group oraz potwierdził poparcie Rosji dla Indii i jej stałego członkostwa w rozszerzonej Radzie Bezpieczeństwa ONZ. Poza tym obaj liderzy wspólnie wystąpili na szczycie biznesowym Indie-Rosja. Do kolejnego, już 20. spotkania na dorocznym szczycie doszło we Władywostoku w dniach 4-5 września 2019 r. W tym czasie odbywał się w tym mieście V Wschodni Szczyt Gospodarczy, którego indyjski premier był gościem honorowym. Efektem wizyty premiera Modiego było podpisanie czternastu porozumień w dziedzinie handlu i inwestycji, współpracy obronnej, transportu drogowego i współpracy w sektorze naftowo-gazowym ${ }^{53}$.

Sporna kwestia Kaszmiru dała o sobie ponownie znać latem 2019 r., kiedy Indie unieważniły specjalny status Kaszmiru. I tym razem Moskwa wsparła New Delhi, uznając decyzję rządu indyjskiego za jego sprawę wewnętrzną ${ }^{54}$. Natomiast w czerwcu 2020 r. rząd rosyjski zorganizował w Moskwie

53 Bilateral Relations: India-Russia Relations, https://iniandembassy-moscow.gov.in/bilateral-relations-india-russia.php [dostęp: 31.07.2020].

54 E. Tamkin, Why India and Russia Are Goint to..., op.cit. [dostęp: 31.07.2020]. 
trójstronne spotkanie ministrów spraw zagranicznych Rosji, Indii i Chin mające rozładować napięcie między New Delhi i Pekinem po starciach zbrojnych obu państw w dolinie rzeki Galwan w himalajskim Ladakhu, które było najpoważniejszym incydentem na spornej granicy indyjsko-chińskiej od ponad pięćdziesięciu lat, a w którym doszło do ofiar śmiertelnych po obu stronach ${ }^{55}$. Ponadto Rosja zapewniła na prośbę Indii, że dostarczy im nowy sprzęt obronny w najbliższych dwóch, trzech miesiącach. Tego samego roku, 13 listopada, doszło do ich spotkania na marginesie szczytu BRICS w Brasilii.

\section{Aspekty gospodarcze}

W latach 90. XX w., jak wspomniano wcześniej, większe zainteresowanie Rosji Zachodem niż Indiami wynikające z fatalnej sytuacji rosyjskiej gospodarki, znalazło swój wyraz w pogorszeniu ich wzajemnych relacji gospodarczych. Co więcej, na to pogorszenie nałożył się inny negatywny czynnik, jakim był dług indyjski wobec Moskwy szacowany od 12 mld USD do 16 mld USD. Jednak problem ten, o czym zasygnalizowano wcześniej, w trakcie wizyty prezydenta Jelcyna w New Delhi w 1993 r. został uregulowany. Ponadto Rosja, która była uznana za główny cel eksportu indyjskiego w latach 1990-2015, nie znalazła się nawet wśród trzydziestu państw, do których Indie eksportują najwięcej. W 1996 r. handel Rosji z Indiami miał udział zaledwie $1 \%$ całkowitego handlu Rosji ${ }^{56}$. W tym

55 N. Makarewicz, Starcia $w$ dolinie rzeki Galwan. „Chiny stracity co najmniej 40 żotnierzy”, 21.06.2020, http://Starcia_w_dolinie_rzeki_Galwan._"Chiny_straciły_co_najmniej_40_żołnierzy"_-_RMF24 [dostęp: 12.12.2020]; E. Tamkin, Why India and Russia Are Going to..., op.cit. [dostęp: 31.07.2020].

56 N. Kapoor, India-Russia Ties in a Changing World Order: In Pur- 
miejscu można dodać, że import rosyjskiego złożonego sprzętu, który był przedmiotem współpracy gospodarczej w 1994 r., był 10 razy mniejszy niż w $1990 \mathrm{r}^{57}$

Według danych zawartych w tabeli 1, za rok fiskalny 1993-1994 wartość wzajemnych obrotów nie przekroczyła 1 mld USD, wynosząc jedynie 905 mln USD, przy czym deficyt handlowy Federacji Rosyjskiej wyniósł ponad $391 \mathrm{mln}$ USD. Cechą charakterystyczną obustronnego handlu był deficyt handlowy Rosji utrzymujący się do roku fiskalnego 2002-2003.

Tabela 1. Handel rosyjsko-indyjski w latach 1993-1994 do 2007-2008 (w mln USD)

\begin{tabular}{|l|c|c|c|c|}
\hline \multicolumn{1}{|c|}{ Rok fiskalny } & Rosyjski eksport & Rosyjski import & Obroty wzajemne & Bilans \\
\hline $1993-1994$ & 256,89 & 648,60 & 905,49 & $-391,71$ \\
\hline $1994-1995$ & 504,54 & 807,38 & 1311,92 & $-302,84$ \\
\hline $1995-1996$ & 857,53 & 1046,55 & 1904,09 & $-189,02$ \\
\hline $1996-1997$ & 628,96 & 811,84 & 1440,80 & $-182,88$ \\
\hline $1997-1998$ & 679,02 & 954,12 & 1633,14 & $-275,10$ \\
\hline $1998-1999$ & 545,42 & 706,26 & 1254,68 & $-160,84$ \\
\hline $1999-2000$ & 623,94 & 948,99 & 1572,93 & $-325,05$ \\
\hline $2000-2001$ & 517,19 & 869,93 & 1387,12 & $-352,74$ \\
\hline $2001-2002$ & 538,36 & 796,83 & 1332,19 & $-258,47$ \\
\hline $2002-2003$ & 592,61 & 704,00 & 1296,61 & $-111,39$ \\
\hline $2003-2004$ & 959,63 & 713,76 & 1673,39 & $+245,87$ \\
\hline
\end{tabular}

Źródło: Gulshan Sachdeva, Indo-Russian Economic Linkages. A Critical Assessment, [w:] India-Russia strategic paartnership. Challneges and Prospects, red. Nivedita Das Kundu, Indian Council of World Affairs, New Delhi 2010, s. 111, za: Department of Commerce, Ministry of Commerce \& Industry, Government of India.

suit of a 'Special Strategic Partnership', „ORF Occasional Paper”, październik 2019, nr 218, s. 1.

57 Nivedita Das Kundu, Indo-Russian Trade Relations: An Overview, „India Quarterly”, lipiec-wrzesień, vol. 67, nr 3, s. 124. 
Natomiast w kolejnych latach, jak wskazują dane z tabeli 1 i 2, ma miejsce do 2019 r. nieprzerwana nadwyżka handlu po stronie rosyjskiej.

Tabela 2. Handel rosyjsko-indyjski w latach 2004-2009 (w mld USD)

\begin{tabular}{|l|c|c|c|c|}
\hline \multicolumn{1}{|c|}{ Rok } & Rosyjski eksport & Rosyjski import & Obroty wzajemne & Bilans \\
\hline 2004 & 1,55 & 0,63 & 2,18 & $+0,92$ \\
\hline 2005 & 2,31 & 0,78 & 3,09 & $+1,53$ \\
\hline 2006 & 2,98 & 0,96 & 3,95 & $+2,02$ \\
\hline 2007 & 4,01 & 1,30 & 5,32 & $+2,71$ \\
\hline 2008 & 5,23 & 1,71 & 6,94 & $+3,52$ \\
\hline 2009 & 5,93 & 1,52 & 7,46 & $+4,41$ \\
\hline
\end{tabular}

Źródło: Overview of India-Russia Economic Cooperation, s. 3, https://indianembassy-moscow.gov.in/overview.php [dostęp: 31.07.2020].

Wartość w rosyjsko-indyjskich obrotach handlowych w 2009 r. wzrosła istotnie w stosunku do poprzednich lat, osiągając 7,4 mld USD. Obie strony ustaliły w tym roku cel osiągnięcia 20 mld USD w obustronnym handlu w 2015 r. W 2011 r. wartość obustronnego handlu wyniosła 8,9 mld USD (rosyjski eksport - 6,1 mld USD, import - 2,8 mld USD). Od 2013 do 2016 r. miał miejsce proces spadkowy w wymianie handlowej, natomiast w 2017 r. odnotowano dodatni wzrost o 21,6\%. W kolejnym 2018 r. miała miejsce kontynuacja pozytywnego trendu wzrostu w stosunku do roku poprzedniego, osiągając wartość 9,480 mld USD. Jednak w 2019 r. obustronna wartość handlu wyniosła 9,100 mld USD, co oznaczała spadek o 380 mln USD.

Jak z danych w tabeli 2 i 3 wynika, że pomimo globalnego kryzysu finansowego, stosunki handlowe i gospodarcze pomiędzy obu partnerami do 2013 r. rosły. 
Tabela 3. Handel rosyjsko-indyjski w latach 2010-2017 (w mld USD)

\begin{tabular}{|l|c|c|c|c|}
\hline \multicolumn{1}{|c|}{ Rok } & Rosyjski eksport & Rosyjski import & Obroty wzajemne & Bilans \\
\hline 2010 & 6392 & 2143 & 8535 & +4249 \\
\hline 2011 & 6080 & 2786 & 8866 & +3294 \\
\hline 2012 & 7563 & 3041 & 10604 & +4522 \\
\hline 2013 & 6983 & 3091 & 10074 & +3892 \\
\hline 2014 & 6341 & 3172 & 9513 & +3169 \\
\hline 2015 & 5571 & 2258 & 7829 & +3313 \\
\hline 2016 & 5313 & 2397 & 7710 & +2916 \\
\hline 2017 & 6456 & 2902 & 9358 & +3554 \\
\hline 2018 & 6920 & 2560 & 9480 & +4360 \\
\hline 2019 & 6230 & 2870 & 9100 & +3360 \\
\hline
\end{tabular}

Źródło: India-Russia Trade in 2010-2017 (Except Military-Technical Cooperation), 2.10.2018; India IND) exports, imports, Russia (RUS) exports, imports, http://www.oec.world/en/profile/country/rus,ind [dostęp: 16.01.2021]. India-Russia Trade in 2010 - 2017 (Except Military-Technical Cooperation) - Valdai Club, 25.12.2020, za 2019 r.: India imports from Russia; India exports to Russia, http://India_exports_to_Rusiia_-_1992-2019_ Data_/_2021_Forecast_(tradingeconomics.com) [dostęp: 2.01.2021].

Ważnym indyjskim towarem eksportowym na rynek partnera rosyjskiego w 2000 r. były farmaceutyki, które dały na nim drugie miejsce Indiom po Republice Federalnej Niemiec $^{58}$. Innym, najbardziej charakterystycznym towarem we wzajemnym handlu są diamenty. Wydobywane są one na Rosyjskim Dalekim Wschodzie, a następnie eksportowane do Indii, gdzie Hindusi poddają je szlifowaniu. W tym miejscu należy dodać, że 90\% wydobywanych w świecie diamentów przechodzi przez Indie, a konkretnie przez stan Gudżarat, który jest rodzinnym stanem obecnego premiera Narendrę Modiego.

58 E. Tamkin, Why India and Russia Are Going to..., op.cit. 
W 2014 r. doszło do spadku wartości wzajemnych obrotów handlowych do $9 \mathrm{mld} 513 \mathrm{mln}$, przy utrzymaniu nadwyżki ze strony rosyjskiej 3 mld 169 mln USD. Rosja głównie eksportowała perły i drogocenne kamienie, maszyny, wyposażenie elektroniczne, nawozy i aparaty fotograficzne do Indii. Ze swej strony Indie eksportowały składniki farmaceutyków, wyposażenie elektryczne, kawę, herbatę, odzież, perły i cenne kamienie ${ }^{59}$. W 2016 r., jako partner handlowy, Indie zajęły 17 miejsce na rosyjskiej liście, podczas gdy Rosja na indyjskiej zajęła 26. miejsce. Różnice w wartości obrotów handlowych Federacji Rosyjskiej z Indiami, w stosunku do wartości obrotów handlowych Indii z USA i ChRL są ogromne. W latach 2014, 2015, 2016 i 2017 obroty Indii z USA były następujące w kolejności rosnącej wymienionych lat: 66,9 mld USD, 66,2 mld USD, 67,7 mld USD i 74,3 mld. W przypadku ChRL: 95 mld USD, 68,1 mld USD, 69,5 mld USD i 84,07 mld $^{60}$. W przypadku Federacji Rosyjskiej, zgodnie z tabelą 2: 9,5 mld USD, 7,8 mld USD, 7,7 mld USD i 9,3 mld USD.

W 2018 r. wśród pięciu największych partnerów handlowych Rosji znalazły się w kolejności: Chiny (108,3 mld USD), Niemcy (59,6 mld USD), Holandia (47,2 mld USD), Białoruś (34 mld USD) i Włochy (27 mld USD). Natomiast wśród największych partnerów handlowych Indii w roku fiskalnym 2017-2018 znalazły się: Chiny (89,7 mld USD), USA (74,5 mld USD), UAE - Zjednoczone Emiraty Arabskie (49,9 mld USD), Arabia Saudyjska (27,5 mld USD) i Hong Kong $(25,4 \text { mld USD })^{61}$. Natomiast za 2018 r., jak wynika

\footnotetext{
59 N. Kapoor, India-Russia Ties in a Changing..., op.cit., s. 4.

60 Ibidem, s. 12.

61 Ibidem, s. 5-6.
} 
z danych w tabeli 3, wartość obrotów rosyjsko-indyjskich wyniosła jedynie 9 mld 100 mln USD, co wyglądało bardzo blado w porównaniu do wartości obrotów handlowych Rosji z jej największymi partnerami handlowymi.

Wymienia się kilka czynników, które składają się na słabość więzi gospodarczych Rosji i Indii. Przede wszystkim brak zaangażowania sektora prywatnego. Następnie: brak logistyki, kiepska komunikacja i najnowszy - stagnacja w Międzynarodowym Korytarzu Gospodarczym Północ-Południe z powodu wysokich kosztów ${ }^{62}$. Zbudowanie tego korytarza, według szacunków, mogłoby przynieść oszczędności w kosztach transportowych rzędu $20 \%{ }^{63}$.

Trzeba mieć na uwadze, że głównymi rosyjskimi towarami eksportowymi są surowce energetyczne - ropa naftowa, gaz, energia nuklearna (elektrownie) oraz sprzedaż produktów przemysłu zbrojeniowego i związane z nimi technologie. Podczas gdy w ostatnich latach w rosyjsko-indyjskim sektorze energetycznym wzrosła współpraca przez obustronne inwestycje, mają miejsce, jak zwykle, trudności w zaangażowaniu bezpośredniego dostarczania surowców energetycznych rurociągami ${ }^{64}$.

W 2018 r. najważniejszymi pozycjami eksportu rosyjskiego do Indii były: po pierwsze: paliwa mineralne, oleje mineralne i produkty ich destylacji - substancje bitumiczne i woski mineralne; po drugie: perły naturalne lub hodowlane, kamienie szlachetne lub półszlachetne i metale szlachetne; po trzecie: reaktory jądrowe, kotły, maszyny i urządzenia

62 Ibidem.

63 L.S. Ivanowich, Economic Subsysstem of Russia-India - Relations, [w:] India-Russia strategic paartnership. Challneges and Prospects, red. Nivedita Das Kundu, New Delhi 2010, s. 98.

64 N. Kapoor, India-Russia Ties in a Changing..., op.cit., s. 4. 
mechaniczne; czwarte w kolejności: maszyny i urządzenia elektryczne oraz ich części i piąte z kolei nawozy. Natomiast ze strony indyjskiej wśród pięciu największych pozycji eksportowych do Rosji w latach 2017-2018 znalazły się: 1) produkty farmaceutyczne; 2) maszyny i urządzenia elektryczne oraz ich części; 3) reaktory jądrowe, kotły, maszyny i urządzenia mechaniczne oraz ich części; 4) chemikalia organiczne; 5) pojazdy inne niż tabor kolejowy lub tramwajowy oraz ich części i akcesoria ${ }^{65}$. Jeśli chodzi o dwustronny handel usługami jest stabilny od 2014 r. z bilansem korzystnym dla Rosji. W 2017 r. wartość obrotów usługami wyniosła 1 mld 95 mln USD. W 2018 r. była nieznacznie mniejsza, osiągając $999 \mathrm{mln}$ USD. Natomiast w pierwszej połowie 2019 r. wyniosła już prawie $644 \mathrm{mln} \mathrm{USD}^{66}$.

Rozwojowi stosunków gospodarczych towarzyszyła instytucjonalizacja. Od połowy lat 90. XX w. odbywają się coroczne spotkania Komisji do spraw Współpracy Handlowej, Gospodarczej, Naukowej, Technicznej i Kulturalnej, która jest głównym instytucjonalnym mechanizmem sprawowania nadzoru nad współpracą gospodarczą. W jej skład weszły grupy robocze, takie jak: do spraw współpracy gospodarczej i handlowej; modernizacji i współpracy przemysłowej; energii; turystyki i kultury oraz nauki i technologii. W 2007 r. powstało Indyjsko-Rosyjskie Forum do spraw Handlu i Inwestycji. W tym samym roku doszło do powstania Rosyjsko-Indyjskiej Rady do spraw Promocji Handlu, Inwestycji i Technologii. W lutym 2008 r. została powołana do życia Rosyjska Rada CEO, która jest jednym

65 Bilateral Relations: India-Russia Relations, https://indianembassy-moscow.gov.in./bilateral-relations-india-russia.php [dostęp: 31.07.2020]

66 Ibidem. 
z głównych podstawowych mechanizmów promocji bezpośrednich kontaktów między firmami ${ }^{67}$. W czerwcu 2010 r. na prestiżowym Międzynarodowym Forum Gospodarczym w Sankt Petersburgu został przeprowadzony pierwszy Dia$\log$ Biznesu Indie-Rosja ${ }^{68}$. Natomiast na początku drugiej dekady obecnego wieku, w latach 2011-2012 otwarto Indyjsko-Rosyjskie Centrum Nauki i Technologii.

Obustronna instytucjonalizacja gospodarcza została pogłębiona w 2018 r. 26 listopada w Sankt Petersburgu odbył się I Strategiczny Dialog Gospodarczy Indie-Rosja, a 11 grudnia doszło do pierwszego szczytu Indie-Rosja Startup Summit ${ }^{69}$.

W tym miejscu można wspomnieć, że społeczność indyjska znajdująca się w Federacji Rosyjskiej oceniona została na 15 tys. osób w 2012 r. W tym doliczono się 500 indyjskich biznesmenów, z których 200 rezyduje w samej Moskwie. Firm indyjskich było zarejestrowanych około 300, z czego większość zajmowała się handlem. Firmy te sprowadzały produkty z Indii, takie jak: herbata, kawa, tytoń, farmaceutyki, ryż, przyprawy korzenne, obuwie skórzane, IT - technikę informacyjną ${ }^{70}$. Jednak trzeba dodać, że w następstwie ogólnego spowolnienia gospodarczego i trwającego sporu Rosji z Zachodem o Ukrainę, strona rosyjska położyła nacisk na substytucję importu, co doprowadziło do znacznego ograniczenia handlu zagranicznego Rosji, w tym

67 India-Russia Relations, http://mea.gov.in/Portal/ForeingRelations/Russia_undassified_bilateral_January_2013.pdf [dostęp: 1.07.2018].

$681^{\text {th }}$ Session of the India-Russia Economic Joint Commission meeting. Category:Visits and Summits Thursday, 18.11.2010, http://rusembinda.com/visist-and-summits/1887-16th...meting2tmpl=format=pdf [dostęp: 1.07.2018].

69 Bilateral Relations: India-Russia Relations..., op.cit.

70 India-Russia Relations..., op.cit. 
z Indiami ${ }^{71}$, które zobrazowane są danymi za lata 2014-2016 w tabeli drugiej.

Niemniej jednak czynione są kroki, które mogą zapewnić znaczący impuls dla obustronnego handlu. Wśród nich należy wymienić operacjonalizację projektu „Zielonego Korytarza”, Międzynarodowy Korytarz Transportowy Północ-Południe oraz umowę o wolnym handlu z Euroazjatycką Unią Gospodarczą (EUG). W dniach 30-31 stycznia 2019 r. w New Delhi doszło do pierwszej rundy konsultacji technicznych w sprawie umowy o wolnym handlu Indie-EUG, kolejna odbyła się w czerwcu w Moskwie ${ }^{72}$. Obie strony współpracują również nad realizacją „mostu energetycznego" między dwoma państwami, który ma się opierać na cywilnej współpracy jądrowej, pozyskiwaniu LNG, partnerstwie w sektorze ropy naftowej i gazu oraz zaangażowania w odnawialne źródła energii ${ }^{73}$.

Ze swej strony Rosja wykazywała szczególne zainteresowanie we współpracy w sektorach, takich jak: telekomunikacyjny, budowy statków i wysokich technologii, obejmujących przestrzeń kosmiczną ${ }^{74}$. Spektakularnym przykładem dobrej współpracy jest wspólne rozwijanie rosyjskiego systemu globalnej nawigacji satelitarnej "Glonass” do "Glonass-M” i „Glonass-K”. W tym czasie Rosja podjęła zamiar zwiększenia, z udziałem Indii, systemu Glonass do 18 satelitów i pełnej orbitalnej grupy 24 satelitów z końcem 2009 r. Także pojawił się wspólny projekt dotyczący budowy rosyjsko-indyjskiego naukowo-edukacyjnego sztucznego satelity „YouthSat”, któ-

71 Bilateral Relations: India-Russia Relations..., op.cit.

72 Ibidem.

73 Ibidem.

74 Kundu Nivedita Das, India's Strategic Cooperation with Russia..., op.cit., s. 77. 
ry został opracowany na podstawie umowy między Rosyjską Federalną Agencją Kosmiczną i Indyjską Organizacją Badań Kosmicznych (ISRO). Rosja przyłączyła się także do indyjskiego projektu księżycowego „Chandrayan II”. Ponadto oba państwa realizują badania dotyczące możliwości rozwoju wyposażenia dla ziemskich sond i w obszarze silników elektrycznych dla statków kosmicznych oraz wspólne projekty dotyczące sondowania powierzchni księżyca i zbudowania obserwatorium słonecznego w przestrzeni kosmicznej do badania promieniowania rentgenowskiego ${ }^{75}$. W 2014 r. Indie uruchomiły własny system nawigacji satelitarnej. Co więcej, z sukcesem zaimplementowały silnik kriogeniczny rodzimej produkcji do rakiet nośnych oraz również w 2014 r. wprowadziły na orbitę Marsa pierwszy orbiter ${ }^{76}$. Wśród dokumentów leżących u podstaw współpracy indyjskiej w dziedzinie eksploracji kosmosu znalazły się m.in.: memorandum o wzajemnej współpracy zawarte pomiędzy Rosyjską Federalną Agencją Kosmiczną (Roskosmos) i Indyjską Organizacją Badań Kosmicznych (ISRO) z 12 listopada 2003 r.; umowa z 3 grudnia 2004 r. O współpracy nad badaniem i wykorzystaniem przestrzeni kosmicznej w celach pokojowych i umowa z 6 grudnia 2012 r. - O długoterminowej współpracy nad rozwojem i wykorzystaniem rosyjskiego globalnego systemu nawigacji satelitarnej (GLONASS) ${ }^{77}$.

Rosyjskie inwestycje w Indiach w 2017 r. osiągnęły wartość 18 mld USD, a łączne inwestycje Indii w Rosji wyniosły

75 Ibidem, s. 77-78.

76 N. Olszanecka, Rosyjsko-indyjska wspótpraca w dziedzinie..., op.cit., s. 120 .

77 Ibidem, s. 113-114. Bliżej na temat Projektu Chandrayaan-2, Globalnego Nawigacyjnego Systemu Satelitarnego - GLONNAS i Koronas-Foton, zob. ibidem, s. 114-118. 
13 mld USD. Zatem ogólny cel inwestycyjny w wysokości 30 mld USD, który został wyznaczony na 2025 r., został przekroczony. Większość inwestycji indyjskich w Rosji dotyczyła węglowodorów, natomiast strona rosyjska inwestowała głównie w motoryzację i telekomunikację ${ }^{78}$. Poza tym strona indyjska miała swój udział w Parkach Przemysłowych, platformach technologicznych, w sektorach takich jak farmaceutyczny, nawozy sztuczne, węgiel i energia. Natomiast strona rosyjska, oprócz wspomnianej motoryzacji i telekomunikacji, nastawiła się na inwestycje w główne projekty infrastrukturalne, takie jak DMIC, Inteligentne Miasta (Smart Cities) i Korytarze Kolejowe (Freight Corridors), jak również w takie sektory, jak energia i drogi ${ }^{79}$.

Niewątpliwie ważnym obszarem współpracy jest pokojowe wykorzystanie energii nuklearnej. Jak wspomniano wcześniej, w 1998 r. Federacja Rosyjska i Indie wznowiły porozumienie z 1988 r, dotyczące budowy elektrowni atomowej w Indiach o mocy 2 x 1000 MW ${ }^{80}$, której budowa rozpoczęła się w $2002 \mathrm{r}$.

Jak nadmieniono wcześniej, w latach 70. XX w. Grupa Nuklearnych Dostawców (NSG) skutecznie zakazała eksportu obiektów nuklearnych do Indii. Ważną zatem cezurą czasową był 2005 r., kiedy ówczesna amerykańska administracja George’a Busha wynegocjowała porozumienie („123 Agreement"), zgodnie z którym Indie zobowiązały się oddzielić swoje cywilne i wojskowe obiekty nuklearne oraz poddać wszystkie swoje cywilne obiekty jądrowe pod kontrolę Międzynarodowej Agencji Energii Atomowej (IAEA

78 Bilateral Relations: India-Russia Relations..., op.cit.

79 Joint Statement Druzhba-Dosti: A Vision for strengthening..., op.cit.

80 Ibidem, s. 76. 
- International Atomic Energy Agency). W związku z tym w sierpniu 2008 r. IAEA zatwierdziła umowę zabezpieczeń z Indiami, a NSG pozwoliła im na dostęp do cywilnej technologii jądrowej i paliwa ${ }^{81}$.

Od 2008 r. pojawiały się często raporty, że rozpoczęcie działalności reaktorów jest bliskie. W międzyczasie, 12 marca 2010 r. strony, rosyjska i indyjska, podpisały wspomnianą „Mapę drogową dla serii budowy zaprojektowanych rosyjskich elektrowni atomowych w Republice Indii" (w skrócie „Mapa Drogowa”). Zostały podpisane dwa protokoły ustaleń pomiędzy Państwową Atomową Korporacją „Rosatom” i Departamentem Energii Atomowej Rządu Indii. Pierwszy, z 21 grudnia 2010 r., dotyczył szerszej współpracy naukowej i technicznej na polu pokojowego wykorzystania anergii atomowej. Natomiast drugi, podpisany 20 czerwca 2011 r., był na temat współpracy z Globalnym Centrum dla Partnerstwa Energii Nuklearnej Indii ${ }^{82}$. Jednak do 2013 r. nawet pierwszy reaktor nie został uruchomiony. Kiedy doszło do jego uruchomienia okazało się, że to przedsięwzięcie uznane w grudniu 2014 r. za komercyjne nie uzyskało licencji na działanie od Rady Regulacji Energii Atomowej (Indii), która została uzyskana pół roku później ${ }^{83}$.

W 2014 r. Państwowa Korporacja Energii Atomowej „Rosatom” (State Atomic Energy Corporation „Rosatom”) i Ministerstwo Energii Atomowej Indii przygotowały dokument zatytułowany: „Strategiczna wizja umacniania współpracy

81 S. Thomas, Russia's Nuclear Export..., op.cit., s. 239.

82 Strategic Vision for Strenghtening Cooperation in Peaceful Uses of Atomic Energy Between the Republic of India and the Russian Federation, Dec 11, 2014, Friday, Embassy of the Russian Federation in the Republic of India, 12.12.2014, http://resembinda.com/official-documents/788-strategic-dec-11-2014?tmpl=component\&format=pdf [dostęp: 31.07.2020].

83 Ibidem, s. 241. 
w pokojowym wykorzystaniu energii atomowej pomiędzy Rosyjską Federacją i Republiką Indii”. Dotyczyła ona strategicznych wskazówek w tym obszarze.

Tymczasem pierwsze trzy lata eksploatacji jednostki wykazały jej zawodność. W sierpniu 2016 r. druga jednostka została podłączona do sieci, ale nie weszła do komercyjnej eksploatacji do marca 2017 r. z powodu poważnych wad technicznych ${ }^{84}$. Wcześniej w kwietniu 2014 r. Rosatom podpisał umowę z indyjskim klientem, NPCH, dotyczącą zbudowania dwóch reaktorów w Kudankulamie, ale ponownie pojawiły problemy. Początek budowy trzeciej i czwartej jednostki nie rozpoczął się aż do czerwca i października 2017 r. Jednym z problemów, który nie został rozwiązany była kwestia odpowiedzialności sprzedawcy pomimo podpisania przez Indię „Konwencji o dodatkowej kompensacji szkód jądrowych" (the Convention on Supplementary Compensation for Nuclear Damage) w lutym 2016 r. Pomimo tych problemów, w tym samym roku osiągnięto ogólne ramy porozumienia i protokół kredytu dla budowy jednostek 5 i 6 . W tym miejscu trzeba dodać, że Indie mają ambine nuklearne plany rozwoju. Przed 2032 r. chcą osiągnąć 62 GW w eksploatacji energii atomowej. Koszt ma wynieść 155 mld $\mathrm{USD}^{85}$.

\section{Aspekty militarne}

Po upadku Związku Radzieckiego rosyjskie zakłady zbrojeniowe straciły prawie $80 \%$ ich finansowania od rządu rosyjskiego. Równolegle miała miejsce utrata dochodów ekspor-

\footnotetext{
84 Ibidem.

85 Ibidem, s. 242.
} 
towych z powodu zaniku tradycyjnego radzieckiego rynku państw realnego socjalizmu i ogólnego spadku na światowym rynku zbrojeniowym. W latach 90 . XX w. rosyjski budżet obronny spadł na poziomy, które były częścią z okresu radzieckiego i wyraźnie były niewystarczające na wsparcie wielu istniejących firm zbrojeniowych należących do ogromnego Kompleksu Przemysłowo-Militarnego (Military Industrial Complex - MIC). Kompleks ten obejmował 2 tys. przedsiębiorstw, 900 organizacji badawczych i ośrodki projektowania. Łącznie zatrudnionych w kompleksie było około 5 mln osób ${ }^{86}$.

Pomimo tej sytuacji, Indie importowały broń od Federacji Rosyjskiej, w którą wyposażały swoją armię, marynarkę wojenną i siły powietrzne. Na początku 1992 r. strona rosyjska wystąpiła z propozycjami dotyczącym wspólnej produkcji, tj. udziału w finansowaniu, wspólnych badań, rozwoju i eksportu, głównie dotyczących równoległej produkcji samolotów MIG-29 i czołgów T-72MI zarówno w Rosji, jak i Indiach. Moskwa wyraziła wówczas także gotowość do negocjowania dotychczasowych porozumień odnośnie czołgów T-72S i linii produkcyjnej MIG-21 ${ }^{87}$.

We wrześniu 1992 r. ówczesny indyjski minister obrony, Sharad Pawar, złożył wizytę w Moskwie, w trakcie której, ze swoim odpowiednikiem Pawłem Graczowem, sporządził wersję roboczą obustronnego traktatu na temat wszechstronnej współpracy wojskowej. Jednak w trakcie rozmowy między obu ministrami potwierdzono niewystarczające dostawy części zamiennych do Indii. Ponadto Indie narzekały na nieregu-

86 A. Sahgal, India-Russia Defence Cooperation. Pespectives and Prospects, [w:] India-Russia Strategic Partnership. Challenges and Prospects, red. Nivedita Das Kundu, New Delhi 2010, s. 27.

87 B. Gogoi, Military-Technical Collaboration Between India and Russia..., op.cit., s. 307. 
larne dostawy towarów, szczególnie broni, części zamiennych i ropy naftowej ${ }^{88}$. W związku z tym indyjski minister Pawar złożył kolejną wizytę na Ukrainie w październiku 1992 r., najwyraźniej czyniąc wysiłek w przekazaniu przesłania stronie rosyjskiej, że mają miejsce inne źródła, aby zaspokoić potrzeby obronne Indii. W tym miejscu trzeba dodać, że Ukraina była głównym centrum produkcji broni w byłym ZSRR i dostawcą do Indii w ramach indyjsko-radzieckich kontraktów obronnych. Ukraina zgodziła się na dostarczenie uzbrojenia i części zamiennych do Indii w zamian za leki i odzież oraz częściową płatność w twardej walucie ${ }^{89}$.

W styczniu 1993 r. doszło do wspomnianej wcześniej wizyty prezydenta Jelcyna w Indiach, w trakcie której został podpisany Indyjsko-Rosyjski Traktat o Przyjaźni i Współpracy. Jednak w traktacie nie znalazły się klauzule obejmujące wzajemne zapewnienia na temat kwestii bezpieczeństwa, które kształtowały opokę Indyjsko-Radzieckiego Traktatu o Pokoju przez dwadzieścia lat. W przeciwieństwie do indyjsko-radzieckiego traktatu w nowo podpisanym traktacie nie znalazło się słowo „pokój”. Tym samym nie znalazł się w nim strategiczny wymiar. Oznaczało to fakt, że strategicznie oba państwa stały się marginalne we wzajemnym postrzeganiu się. Prezydent Jelcyn oświadczył: „My nie chcemy żadnych »toporów«, »trójkątów«, »wielokątów« czy jakichkolwiek innych bloków. My nie chcemy uczestniczyć w żadnym bloku. My chcemy budować nasze stosunki dwustronne obejmujące te $\mathrm{z}$ Indiami, na bilateralnej podstawie, niewymierzone w żadną trzecią stronę" ${ }^{90}$.

\footnotetext{
88 Ibidem, s. 308.

89 Ibidem.

90 Ibidem, s. 309.
} 
Najniższy punkt we wzajemnych relacjach, w okresie prezydentury Jelcyna, został osiągnięty w połowie 1993 r., kiedy w skutek nacisku Stanów Zjednoczonych prezydent Jelcyn odwołał się do „siły wyższej” i anulował kontrakt pomiędzy organizacjami kosmicznymi, rosyjską i indyjską, ISRO i Glavkosmos, na dostarczenie siedmiu silników kriogenicznych i związanych z nimi technologiami ${ }^{91}$. W tym czasie Rosja była otwarcie zaangażowana z Zachodem w wywieraniu presji na Indie w podpisaniu NPT, który Indie otwarcie odrzucały jako dyskryminacyjny wobec państw nienuklearnych $^{92}$.

Niemniej jednak pokaz dojrzałości i realizmu mógł być łatwo zaobserwowany w prowadzeniu stosunków dwustronnych pomiędzy obu państwami, także w tych kwestiach, które nie wypaczyły wzajemnie korzystne stosunki. Wyrazem tego były osiągnięcia wizyta premiera P.V. Narasimhy Rao w Rosji w lipcu 1994 r., w trakcie której zostało osiągnięte szerokie porozumienie. Został zaakceptowany pięcioletni plan umocnienia współpracy obronnej. Dwa porozumienia obronne, które zostały podpisane określiły wymiary nowych stosunków wzajemnie korzystnych. Miały miejsce dwie różnice, które były godne uwagi. Po pierwsze, stary ideologiczny bagaż został wyrzucony po drugie, prywatny sektor zaczął odgrywać główną rolę. Nowych perspektyw wzajemnym stosunkom dostarczyła także wizyta premiera Wiktora Czernomyrdina w Indiach w grudniu $1994 \mathrm{r}^{93}$

Kolejnym krokiem w wojskowych stosunkach rosyjsko-indyjskich była wizyta premiera Deve Goda w Moskwie

\footnotetext{
91 Ibidem, s. 310.

92 Ibidem.

93 Ibidem, s. 311.
} 
w marcu 1997 r., w trakcie której został podpisany kontrakt wojskowy dotyczący zakupu najnowocześniejszych myśliwców rosyjskich SU 30K za około 1,5 mld USD. Tego samego roku na początku października złożył wizytę w Moskwie minister obrony, Mulayam Sintgh Yadav. Obie strony zgodziły się wówczas przedłużyć wojskową współpracę techniczną do 2012 r. Na uwagę zasługuje także wizyta ministra obrony Igora D. Dietiejewa w New Delhi, gdzie ze swoim odpowiednikiem podpisał porozumienie o współpracy wojskowej dotyczącej szkolenia indyjskiego personelu obronnego w kluczowych rosyjskich akademiach wojskowych. Natomiast 27 grudnia 2000 r. oba państwa podpisały największe pojedyncze porozumienie zbrojeniowe. Zgodnie z nim w Indiach miało być wyprodukowane z rosyjską pomocą 150 SU30 MKI. Oznaczało to całkowity transfer technologii do Indii ${ }^{94}$.

Zatem po okresie ostrego spadku zakupu broni w latach 1990-1993 Indie pojawiły się jako wiodący importer rosyjskiego uzbrojenia. W połowie lat 90. XX w. eksport Rosji do Indii i Chin miał udział w 41\% całkowitego dochodu jej przemysłu obronnego. Trzeba podkreślić, że jeszcze w 1992 r. Indie i Rosja wynegocjowały porozumienia dotyczące sprzedaży broni wartości 650 mln USD ${ }^{95}$. Ponadto Indie, importując masowo broń z byłego Związku Radzieckiego, w latach 90. XX w. potrzebowały do niej dużych dostaw części zamiennych, aby móc ją wyremontować ${ }^{96}$.

W sumie, na przełomie XX i XXI w., na 3400 czołgów posiadanych przez armię indyjską, aż 2200 były produkcji

94 Ibidem, s. 311-315.

95 N. Kapoor, India-Russia Ties in a Changing World..., op.cit., s. 1.

96 A. Sahgal, India-Russia Defence Cooperation..., op.cit., s. 25. 
rosyjskiej, wyposażenie indyjskich sił powietrznych w $80 \%$ było rosyjskie, a $85 \%$ wyposażenia indyjskiej marynarki wojennej również było rosyjskie. Indie były wówczas jedynym państwem, który z Rosją miał długoterminowy program technicznej współpracy wojskowej wart więcej niż $8 \mathrm{mld}$ USD $^{97}$.

W połowie pierwszej dekady XXI w., więcej niż 50\% indyjskiej struktury obronnej i jej nowych odpowiedników pochodziło z Rosji. Zasadniczo proporcje uzależnienia Indii od rosyjskich części zamiennych wynosiło 40\% dla sił lądowych, 64\% dla powietrznych sił zbrojnych, 80\% dla marynarki wojennej ${ }^{98}$.

Tym samym, poza Chinami, Indie miały swój istotny udział w utrzymaniu na powierzchni rosyjskiego przemysłu zbrojeniowego. Niewątpliwie był to jeden z elementów konsekwentnego popierania przez Moskwę ambicji nuklearnych Indii, które w 1998 r. przeprowadziły drugą rundę testów jądrowych, co z kolei doprowadziło do kolejnego ochłodzenia w stosunkach Waszyngtonu z New Delhi. Poparcie przez stronę rosyjską indyjskich ambicji nuklearnych, jak i pójście naprzód w budowie dwóch elektrowni atomowych o mocy 1000 MW każdej w Kudankulam, których budowę przewidywało jeszcze porozumienie radziecko-indyjskie, zaowocowało podpisaniem w 1998 r. długoterminowego porozumienia o współpracy militarno-technicznej aż do 2010 r. ${ }^{99}$

W 2001 r. Rosja i Indie podpisały wspólny protokół powiększenia i sprecyzowania w szczegółach, długotermino-

97 B. Gogoi, Military-Technical Collaboration Between India and Russia..., op.cit., s. 307.

98 D.A. Mahapatra, Indo-Russian Economic Cooperation: Surmounting..., op.cit., s. 109.

99 A. Sahgal, India-Russia Defence Cooperation..., op.cit., s. 25. 
wego programu współpracy obronnej aż do 2010 r. Rosja miała dostarczyć broń wartości 10 mld USD oraz innych sprzęt wojskowy i technologie w trakcie tego okresu ${ }^{100}$.

W 2000 r. został stworzony przez oba państwa formalny mechanizm międzyrządowej Komisji do spraw Współpracy Militarno-Technicznej, której spotkania corocznie odbywają się pod przewodnictwem dwóch ministrów obrony. Kadencja tej komisji została przedłużona na następne dziesięć lat po upływie terminu w 2010 r. Zgoda na przedłużenie kadencji komisji miała miejsce podczas wizyty rosyjskiego ministra obrony Anatolija Serdiukowa w Indiach w październiku 2008 r. Jej znaczenie dla Indii jest wyjątkowe, ponieważ Rosja jest jedynym państwem, który stworzył z nią taki mechanizm ${ }^{101}$. Trzeba dodać, że podczas tej wizyty podkreślono wyraźnie znaczenie badań naukowych i wspólnego rozwoju, wspólnej produkcji systemów i platform oraz wzmacniania wzajemnych relacji pomiędzy siłami zbrojnymi obu państw. Ówczesny indyjski minister obrony, Arackaparambii Kurien Antoniusza, podkreślił, że strona indyjska przeszła drogę od modelu kupujący - sprzedawca do współproducenta na polu projektowania, rozwoju i badań naukowych ${ }^{102}$.

Jak wspomniano wcześniej, podczas pierwszej wizyty prezydenta Putina w Indiach została podpisana Deklaracja o strategicznym partnerstwie i zawarto wiele transakcji związanych ze współpracą wojskową. Transakcje te były największe w historii wzajemnych relacji. Dotyczyły one m.in. lotniskowca "Admirał Gorszkow” (w 2004 r. został sprzedany Indiom, którym został przekazany w 2013 r. po

100 B. Thomas, Putin's India Policy: Mutual Gains for..., op.cit., s. 138.

101 Bilateral Relations: India-Russia Relations..., op.cit., s. 78.

102 A. Sahgal, India-Russia Defence Cooperation..., op.cit., s. 28. 
przebudowie na konwencjonalny lotniskowiec - od 13 listopada 2013 r. jest na służbie Marynarki Wojennej Indii pod nazwa INS Vikramadityja), rakietowych systemów artyleryj-

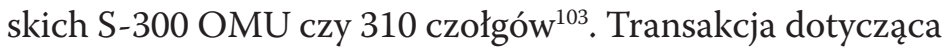
zakupu lotniskowca „Admirał Gorszkow”, została nazwana przez ministrów obrony obu państw, George'a Fernadesa i Siergieja Iwanowa, „historycznym punktem zwrotnym” w stosunkach bilateralnych ${ }^{104}$. Na kolejnym szczycie, tym razem w Moskwie, który odbył się w grudniu 2005 r., zostały podpisane umowy będące kontynuacją zakupów rosyjskiego sprzętu wojskowego przez New Delhi. Wśród nich znalazły się systemy obrony przeciwlotniczej Tunguska M1. Do 2005 r. wartość kontraktów rosyjsko-indyjskich wyniosła 9 mld USD. W latach 2000-2004 Indie były drugim po Chinach odbiorcą rosyjskiego uzbrojenia konwencjonalnego ${ }^{105}$.

Federacja Rosyjska utrzymuje intensywną współpracę militarną z Indiami także przez wspólne ćwiczenia. W maju i czerwcu 2003 r. zostały zrealizowane pierwsze wspólne ćwiczenia marynarki wojennej ${ }^{106}$. Odbyły się one na Oceanie Indyjskim po nazwą Indra-2003 ${ }^{107}$. Natomiast we wrześniu 2005 r. przeprowadzono z kolei pierwsze w historii rosyjsko-indyjskie wojskowe ćwiczenia powietrzno-desantowe na poligonie Mashajan obok Bikaneru ${ }^{108}$. Wspólne ćwiczenia

103 J. Zajączkowski, Indie w stosunkach..., op.cit., s. 225.

104 D.A. Mahapatra, Indo-Russian Economic Cooperation: Surmounting..., op.cit., s. 111.

105 Ibidem.

106 M. de Haas, Russia's Foreign Security Policy In the $21^{\text {st }}$ Century. Putin, Medvedev and Beyond, London-New York 2010, s. 81.

107 B. Thomas, Putin's India Policy: Mutual Gains for..., op.cit., s. 139.

108 Kundu Nivedita Das, India's Strategic Cooperation with Russia..., op.cit., s. 77. 
sił zbrojnych armii, marynarki i lotnictwa obejmujące rosyjskie bombowce strategiczne i jednostki powietrze stały się corocznym wydarzeniem ${ }^{109}$. Nie przeszkodziły one jednak, w kolejnym 2006 r., w podpisaniu cywilnej umowy nuklearnej między Indiami a Stanami Zjednoczonymi, przez premiera Nanmohana Shingha i prezydenta George'a W. Busha, która była kamieniem milowym we wzajemnych relacjach obu państw. Choć trzeba podkreślić, że strona rosyjska stała się jej prawdziwym beneficjentem, ponieważ to ona, a nie strona amerykańska współpracowała ze stroną indyjską przy budowie reaktorów jądrowych, planując równocześnie budowę kolejnych w przyszłości.

24 stycznia 2007 r. odbyło się szóste spotkanie Rosyjsko-Indyjskiej Międzyrządowej Komisji do Spraw Wojskowej Współpracy Technicznej pod przewodnictwem ministrów obrony, Siergieja Borisowicza Iwanowa i Shri A.K. Anony'ego, na której zostały podpisane cztery porozumienia zwiększające współpracę obronną pomiędzy obu państwa$\mathrm{mi}^{110}$.

12 listopada 2007 r., podczas wizyty premiera Manmohana Singha w Rosji, oba państwa podpisały porozumienie dotyczące wspólnego rozwoju wielozadaniowego samolotu transportowego. Powodem było zastąpienie floty starzejących się An-32 indyjskich sił zbrojnych ${ }^{111}$.

Moskwa i New Delhi konsekwentnie kontynuowały współpracę militarną. Jednym z jej ważnych przykładów stała się wspólna produkcja samosterujących pocisków przeciwokrętowych BrahMosk, tj. Brahmaputra-Moskwa, które

109 M. de Haas, Russia's Foreign Sucirity Policy..., op.cit., s. 81.

110 Bliżej na temat porozumień: B. Thomas, Putin's India Policy: Mutual Gains for..., op.cit., s. 142-143.

111 M. de Haas, Russia's Foreign Sucirity Policy..., op.cit., s. 79. 
mogą być wystrzeliwane z okrętów podwodnych, okrętów nawodnych, samolotów i mobilnych autonomicznych wyrzutni. Udziału w ich produkcji podjęło się dziesięć rosyjskich i dwadzieścia indyjskich kompanii. Należy dodać, że Rosja stała się jedynym państwem, które wyraziło gotowość dostarczenia partnerowi indyjskiemu kluczowych technologii potrzebnych do budowy własnych okrętów podwodnych uzbrojonych w pociski nuklearne. Wcześniej Rosja wynajęła Indiom jeden okręt podwodny przystosowany do ataku nuklearnego ${ }^{112}$.

W latach 2000-2009, według formalnych danych liczbowych, rosyjski budżet obronny został zwielokrotniony dziesięć razy, z 5 mld USD do prawie 50 mld USD. Niemniej jednak nie wszystkie pozycje budżetowe na wydatki militarne były brane pod uwagę, m.in. wliczając w to emerytury, obroty w eksporcie broni, R\&D. W związku z tym zachodni eksperci ocenili prawdziwe wydatki na obronę i bezpieczeństwo od trzech do czterech razy więcej, co oznaczało, że Rosja utrzymywała w rankingu światowym trzecie miejsce po Stanach Zjednoczonych i ChRL. Ponadto w pierwszej dekadzie obecnego wieku przesunęła się z czwartego miejsce na pierwsze w sprzedaży broni, stając się największym dostawcą broni na świecie o wartości 6 mld USD rocznie ${ }^{113}$. Wśród największych odbiorców rosyjskiej broni znaleźli się w kolejności ChRL, Indie i Iran ${ }^{114}$.

Na marginesie trzeba podkreślić, że w pierwszej dekadzie obecnego wieku miały miejsce częste narzekania ze strony indyjskich sił zbrojnych, dotyczące nieustających

\footnotetext{
112 Ibidem.

113 Ibidem, s. 166.

114 Ibidem.
} 
problemów z częściami zamiennymi i utrzymywania poparcia dla rosyjskiego sprzętu przez indyjskich negocjatorów. Innymi drażniącymi faktami, na które wskazują jest brak transparentności dotyczącej wyceny (ceny) i niskiej jakości części zamiennych oraz innych monopolistycznych praktyk, które także są powodem tarcia. Narzekania dotyczą również czasu dostarczenia zakupionego sprzętu, który dociera po kilku latach i jest już wówczas przestarzały. Co więcej, zamykane były fabryki produkujące dostarczany sprzęt, co oznaczało brak dostępu do części zamiennych. Indie w tym czasie przed którymi był remont prawie trzech szwadronów Mig-29s, były zaniepokojone strukturalnym defektami w samolotach, które mogły doprowadzić do ich uziemienia ${ }^{115}$.

W drugiej dekadzie obecnego wieku udział rynku Rosji gwarantuje, że pozostaje ona newralgicznym dostawcą dla Indii zarówno nowych broni, jak i części zamiennych. Militarno-techniczna współpraca, która obejmuje transfer technologii i wspólną produkcję stanowi wyjątkową więź bardzo cenną dla Indii. W 2016 r. zostały podpisane porozumienia na corocznym szczycie obejmującymi dostawę Systemu Powietrznych Pocisków Obronnych Zwycięstwo S-400 (S-400 Triumph Air Defence Missile System) i cztery fregaty klasy Admirał Grigorowicz (Admiral Grigorovich-class frigates), które zostały sfinalizowane w 2018 r. oraz umowę dotyczącą produkcji helikopterów Ka-226T w Indiach ${ }^{116}$.

W dniu 21 maja 2018 r. doszło do nieformalnego szczytu rosyjsko-indyjskiego w Soczi pomiędzy prezydentem Władimirem Putinem i premierem Narendrą Modi, którego rezultatem było zaaprobowanie przez premiera Modiego za-

\footnotetext{
115 A. Sahgal, India-Russia Defence Cooperation..., op.cit., s. 28-29.

116 N. Kapoor, India-Russia Ties in a Changing World..., op.cit., s. $6-7$.
} 
kupu systemu obrony przeciwrakietowej S-400 o wartości 5,2 mld USD jeszcze w tym roku, co zablokowało możliwość zakupu innego sprzętu ze Stanów Zjednoczonych. W tym roku została podpisana jeszcze jedna umowa dotycząca projektu dwóch fregat klasy 11356 (wartość 950 mln USD) ${ }^{117}$. W 2019 r. zostały podpisane cztery inne umowy o łącznej wartości 7,47 mld USD ${ }^{118}$.

Jednak trzeba podkreślić, że strona indyjska konsekwentnie realizuje, w drugiej dekadzie obecnego wieku, dywersyfikację źródeł swoich zakupów na broń i obronę, czego przykładem jest m.in. kontrakt wartości 3 mld USD zawarty po wizycie lutowej w 2020 r. prezydenta Donalda Trumpa w New Delhi. W tym miejscu należy podkreślić, że w latach 2016-2018 Stany Zjednoczone wyłoniły się jako największy dostawca broni dla Indii, spychając Rosję na drugą pozycję. W tym samym czasie Indie stały się w 2014 r. największym zagranicznym kupcem amerykańskiej broni ${ }^{119}$.

Obecnie Rosja ze swej strony deklaruje 60\% swoich dostaw. W sumie w latach $2015-201956 \%$ procent całkowitego indyjskiego importu broni pochodziło z Federacji Rosyjskiej ${ }^{120}$.

Ważnym elementem instytucjonalizacji we współpracy militarnej jest wspomniana Komisja Międzyrządowa ds. Wojskowej Współpracy Technicznej, której współprzewodniczą ministrowie obu państw, spotykający się corocznie. Na przykład minister obrony Indii Raksha Mantri Shri

\section{Ibidem. \\ 118 Zob. ibidem. \\ 119 Ibidem, s. 6.}

120 R. Tavanier, Russian-Indian Arms Trade: Between Autarky and Interdependence, htpp://Russian-Indian_Arms_Trade:_Between_Autarky_and_Interdependence_Global_Risk_Insights [dostęp: 30.12.2020]. 
Rajnath Singh złożył wizytę w Moskwie w dniach 5-7 listopada 2018 r. i współprzewodniczył wówczas tej komisji razem z rosyjskim odpowiednikiem Siergiejem Szojgu ${ }^{121}$. We wrześniu 2019 r., w trakcie XX Dorocznego Dwustronnego Szczytu we Władywostoku, obie strony podpisały porozumienie o współpracy w zakresie produkcji części zamiennych do rosyjskiego sprzętu wojskowego ${ }^{122}$. Lata 2018 i 2019 zaznaczyły się także innymi porozumieniami związanymi z obustronną współpracą wojskową, jak i wzajemnymi wizytami wyższych rangą przedstawicieli obu armii różnych rodzajów sił zbrojnych czy kolejną rundą Wojskowej Konferencji Przemysłowej Indie-Rosja ${ }^{123}$.

Jednak pewnym cieniem na wzajemnej współpracy obronnej kładą się trzy czynniki: pierwszym jest dywersyfikacja broni; drugim, rozwijająca się kampania indygenizacji dla przemysłu obronnego w Indiach, której hasłem jest „Atmanirbhar Bharat” - „Samowystarczalne Indie”, opierającym się na inicjatywie Make in India. 9 sierpnia 2020 r. minister obrony Rajnath Singh ogłosił, że Indie nałożą ograniczenia na 101 towarów przeznaczonych dla sił zbrojnych, których łączny koszt wynosi 47 mld USD. Co więcej, minister Singh podkreślił możliwość rozszerzania listy z ograniczeniami. Niewątpliwie wprowadzenie tych ograniczeń w pełni zaszkodziłoby rosyjskiemu przemysłowi obronnemu. Jednak ich wprowadzenie jest możliwe jedynie w długim terminie, a nie w krótkim czy średnim. Przyczynami takiej sytuacji jest to, że niektóre pozycje wymienione na liście nie mogą być produkowane lokalnie głównie z powodu ograniczonej

\footnotetext{
121 Bilateral Relations: India-Russia Relations..., op.cit.

122 Ibidem.

123 Ibidem.
} 
wiedzy naukowej i technologicznej, braku kapitału i powolnych procesów biurokratycznych, a podstawowa technologia zagranicznych komponentów jest niedostępna w Indiach ${ }^{124}$. Przedstawiony plan ograniczeń został ostro skrytykowany za to, że jest w nim dużo retoryki, natomiast jest mało konkretów odnośnie produkcji obronnej i szkicu polityki promocyjnej eksportu. Co się tyczy polityki promocyjnej eksportu nie wspomniano w nim, jak zwiększą się obecne obroty przemysłu obronnego o wartości 11 mld USD do 25 mld USD w 2025 r. ${ }^{125}$

Trzecim czynnikiem są bezpośrednie sankcje UE i NATO wymierzone w rosyjski wojskowy kompleks przemysłowy. Federacja Rosyjska ma dość ograniczoną bazę technologiczno-przemysłową, w związku z tym zmaga się z programami substytucyjnymi importu i rozwojem technologii wykorzystywanych w imporcie z Zachodu, co doprowadziło do ogromnych opóźnień w produkcji. Wreszcie poza sankcjami gospodarczymi nastąpił gwałtowny spadek cen ropy naftowej w 2014 r. i późniejszy spadek kursu rubla, tym samym przyczyniając się do ogólnego spadku produkcji rosyjskiego przemysłu obronnego i zmniejszenia budżetu dostępnego dla państwowych programów uzbrojenia ${ }^{126}$.

Konsekwencją zaistniałej sytuacji jest dążenie zarówno Federacji Rosyjskiej, jak i Indii do zwiększenia strategicznej autonomii sektora obronnego i zwiększenia eksportu, co może być przesłanką do bardziej intensywnego połączenia wspólnych wysiłków, zarówno materialnych, jak i badawczych na polu rozwoju technologii wojskowych dających

\footnotetext{
124 R. Tavanier, Russian-Indian Arms Trade: Between..., op.cit.

125 Ibidem.

126 Ibidem.
} 
wymierne korzyści, m.in. w znaczącym obniżeniu ich kosztów.

\section{Zakończenie}

Z krótkiej analizy stosunków rosyjsko-indyjskich można sformułować kilka wniosków.

Po pierwsze, niewątpliwie u podstaw relacji między Rosją i Indiami stanęły ich wcześniejsze relacje radziecko-indyjskie, czego symbolicznym wyrazem było podpisanie w 1993 r. nowego traktatu o przyjaźni i współpracy, który był wznowieniem radziecko-indyjskiego traktatu o pokoju i przyjaźni z 1971 r., a w dekadzie ostatnich trzydziestu lat Federacja Rosyjska sprawdziła się jako wieloletni partner Indii.

Po drugie, rozwój stosunków rosyjsko-indyjskich jest jednym z kluczowych filarów polityki zagranicznej zarówno dla Rosji, jak i Indii. Od przejęcia urzędu prezydenta Federacji Rosyjskiej przez Władimira Putina stosunki rosyjsko-indyjskie nabrały nowej jakości, co wyraziło się w zwiększonej współpracy w wielu dziedzinach, m.in. politycznej, wojskowej, handlowej, gospodarczej oraz naukowej i technologicznej. Polityka prezydenta Putina utrzymania Indii jako głównego strategicznego partnera wynika nie tylko z utrzymania równowagi z Chinami, ale także z powodu unikalnego położenia geograficznego Indii nad Oceanem Indyjskim.

Po trzecie, wojskowa współpraca techniczna pomiędzy obu państwami przeszła długą ewolucję od formuły nabywca-sprzedawca do wspólnych badań, rozwoju i produkcji zaawansowanych technologii i systemów obronnych. Niemniej jednak dywersyfikacja w zakupie broni i technologii 
wojskowych prawdopodobnie doprowadzi do zmniejszania się znaczenia Federacji Rosyjskiej na tym polu dla partnera indyjskiego. Jednak obecnie stanowi jeden z najważniejszych filarów w stosunkach bilateralnych między obu państwami.

Po czwarte, Federacja Rosyjska nie jest nawet w pierwszej dziesiątce partnerów handlowych Indii, co oznacza, że Indie w polityce zagranicznej Rosji mają przede wszystkim znaczenie strategiczne. Ponadto z powodu sankcji gospodarczych nałożonych przez państwa zachodnie na Rosję oraz ze względu na strukturę rosyjskiego eksportu, perspektywy stania się Rosji jednym z głównych partnerów handlowych i gospodarczych Indii, w dającej przewidzieć się perspektywie, stają się nierealne.

Na koniec trzeba dodać, że dywersyfikacja zakupów broni i technologii wojskowych przez Indie będzie w kolejnych dekadach wyraźnie zmniejszać rolę ogrywaną przez Rosję w indyjskiej polityce zagranicznej, a coraz większą rolę będą odgrywać Stany Zjednoczone. Pojawia się także asymetria gospodarcza na korzyść Indii. PKB Rosji w 2019 r. wyniosło 1 bln 699,9 mld USA, natomiast Indii 2 bln 875,14 mld $\mathrm{USD}^{127}$, czyli PKB Indii było większe ponad 1,5 razy.

\section{Bibliografia}

$16^{\text {th }}$ Session of the India-Russia Economic Joint Commission meeting. Category: 18.11.2010, http://rusembindia.com/ visists-and-summits/18816th-session-of-the-india-russia-economic-joint-commission-.

127 Rosja - PKN; Indie PKB, http://tradingeconomics.com: World Bank [dostęp: 21.01.2021]. 
Biju T., Putin's India Policy: Mutual Gains for Future, „India Quarterly", kwiecień 2007, vol. 63, nr 2.

Bilateral Relations: India-Russia Relations, https://indianembassy-moscow.gov.in/bilateral-relations-india-russia.php.

Belton K.R., An ANZAC-1 - Indo-Russian Alliance? Geopolitical Alternataive for New Zealand and Austrialia, „India Quarterly”, lipiec 2010, vol. 66, nr 2.

Budhwar K. Prem, India-Russia Relations Past, Present and the Future, „India Quarterly”, lipiec 2007, vol. 63, nr 3.

Charłamowa M.A., Siemionowa W.S. (red.), Historia $d y$ plomacji od 1945 r., Warszawa 1980, t. 5, cz. 1, India imports from Russia; India exports to Russia, http://India_exports_to_Rusiia_-_1992-2019_Data_/_2021_Forecast_(tradingeconomics.com).

Gogoi Biblop, Military-Technical Collaboration Between India and Russia: An Overview of the Post-Soviet Period, „India Quarterly”, lipiec 2002, vol. 38, nr 3-4.

Gulshan Sachdeva, Indo-Russian Economic Linkages. A Critical Assessment, [w:] India-Russia strategic paartnership. Challneges and Prospects, red. Das Nivedita Kundu, New Delhi 2010.

Hass Marcel De, Russia's Foreign Security Policy in the $21^{\text {st }}$ Century. Putin, Medvedev and beyond, London-New York 2010.

India-Russia-Relations http://mea.gov.in/Portal/ForeignRelation/Russia_undassified_bilateral_January_2013.pdf.

India-Russia Trade in 2010-2017 (Except Military-Technical Cooperation), India-Russia Trade in 2010-2017 (Except Military-Technical Cooperation) - Valdai Club.

Ivanowich L.S., Economic Subsysstem of Russia-India - Relations, [w:] India-Russia Strategic Partnership. Challne- 
ges and Prospects, red. Nivedita Das Kundu, New Delhi 2010.

Jakimowicz R., Geostrategiczny wybór Rosji u zarania trzeciego tysiaclecia, t. III: Polityka Federacji Rosyjskiej wobec regionu Azji i Pacyfiku, Azji Centralnej i Arktyki, Kraków 2015.

Joint declaration by the Russian Federation and the Republic of India, 3.12.2004, http://rusembindia.com/russia-india-dialogue-en-official-documents/,,/120-official-documents/1760-joint-declaration-by-the-russian-federation-and-the-republic-of-india.

Joint Statement Druzhba-Dosti: A Vision for strengthening the Indian-Russian Partnership over the next decade. Category: Official Documents, 12.12.2014, http://rusembinda.com/official-documents/7090-jointstatement-druzhba-dosti-a-vision-for-strengthening -the-indian-russian-partnership-over-the-next-decade? tmpl=component\&format=pdf.

Joint Statement on the outcome of the Official Visit of H.E. Mr Vladimir V. Putin, President of the Russian Federation to the Republic of India January 25, 2007. Category: Official Documents, 25.01.2007, http://Official-Documents-1759-joint-statement-on-the-official-visit-of-the-mr-Vladimir-v-putin-president-of-the-Republic-of-India-January-25-2007.

Joshi Nirma, Raj Kumar Sharm, India-Russia Relations in a Changing Eurasian Perspectives, „India Quarterly”, marzec 2017, vol. 73, nr 1.

Joshi Nirmala, India and Russia: Enduring Partnership, „India Quarterly", lipiec 2002, vol. 58, nr 3-4.

Kapoor N., India-Russia Ties in a Changing World Order: In Pursuit of a 'Special Strategic Partnership', „ORF Occa- 
sional Paper”, październik 2019, nr 218.

Kundu Nivedita Das, India's Strategic Cooperation with Russia and its 'Near Abroad' States, "India Quarterly”, październik 2008, vol. 64, nr 4.

Kundu Nivedita Das, Indo-Russian Trade Relations: An Overview, „India Quarterly”, lipiec-wrzesień, vol. 67, nr 3.

Kundu Nivedita Das (red.), India-Russia Strategic Partnership. Challenges and Prospects, New Delhi 2010.

List of documents signed during the Official Visit of President of Russian Federation to India, Dec 10-11, 2014, Saturday, 13.12.2014, https://rusenbinda.com/official-documents/7809-list-of-documents-signed-during-the-official-visit-of-president-of-russian-federation-to-India-dec10-11-2014?tmpl+component\&format=pdf.

Mahapatra Debidatta Aurobinda, Indo-Russian Economic Coopearation: Surmounting the Rupee-Reactor Syndrome, „India Quarterly”, październik 2007, vol. 63, nr 4.

Major deals between India and Russia, New Delhi, December 22,2010, Thursday, 23.12.2010, http://rusembindia,com/ russia-india-dialogue-en/official-documents/.../120-officialdocuments/2122major-deals-between-india-and-russia-new-delhi-december.

Makarewicz N., Starcia w dolinie rzeki Galwan. „Chiny stracity co najmniej 40 żolnierzy”, 21.06.2020, http://Starcia_w_dolinie_rzeki_Galwan._"Chiny_straciły_co_najmniej_40_żołnierzy"_-_RMF24.

Official visit to India of the President Vladimir Putin. Decem - ber 24, 2012, 24.12.2012, http://rusembindia.com/ Russia-india-dialogue-en/visits-and-summits/...december-24-2017?tmpl=component\&format=pdf.

Olszanecka N., Rosyjsko-indyjska wspótpraca $w$ dziedzinie 
nauki i eksploracji kosmosu, „Historia i Polityka” 2016, nr 15, 113.PDF, http://dx.doi.org/10.12775/HiP.2016.006. Overview of India-Russia Economic Cooperation, https:// indianembassy-moscow-gov.in/statistics.php.

Prakash Shri, Contemporary India-China-Russia Relations, Dimension of a New Order, „India Quarterly”, lipiec-wrzesień 2005, vol. 61, nr 3.

Press statements following Russian-Indian talks, December 11, 2014, grudzień 2014, http://rusembindia.com/Russia-india-dailogue-en/visits-and-summits/7092-press-state ments-following-russian-indian-takls-december-1120 14 ?tmpl=component\&format $=$ pdf.

Rosja - PKN; Indie PKB, http://tradingeconomics.com.

Russian President Dmitry Medvedev is on and official visit to India on December 20-22, during which cooperation on trade, economic, energy and cultural issues will be discussed, Category: Visits and Summits, 23.12.2010, https:// rusemdbinda.com/2118-...21-22-2010-?tmpl=pdf.

Sahgal A., India-Russia Defence Cooperation. Pespectives and Prospects, [w:] India-Russia Strategic Partnership. Challenges and Prospects, red. Nivedita Das Kundu, New Delhi 2010.

Shaumyan Tatiana, The Eurasian factor in Russian foreign policy. Implications for India, [w:] Eurasia and India. Regional Perspectives, red. K. Warikoo, London-New York 2018.

State visit of the President of the Republic of India Prati - bha Patil to Russia. September 2-6, 2009. Cotegory: Visits and summits, 6.09.2009, http://resembind.com/visit-s-and-summits/1774-state...2-6-2009? tmpl=componente-format $=$ pdf.

Steve T., Russia's Nuclear Export Programme, „Energy Poli- 
cy" 2018, nr 121.

Strategic Vision for Strengthening Cooperation in Peaceful Uses of Atomic Energy Between the Republic of India and the Russian Federation, Dec 11, 2014, Embassy of the Russian Federation in the Republic of India, 12.12.2014, https://rusembinda.comm/official-documents/788-strategic-dec-11-2014?tmpl=component\&format=pdf.

Tamkin E., Why India and Russia Are Going to Stay Friends. Conventional wisdom holds that New Delhi will turn to Washington as it increases competition with Beijing. But Moscow's importance cannot be ignored, 8.07.2020, https://foreignpolicy.com/2020/07/08/russia-india-relations/.

Tavanier R., Russian-Indian Arms Trade: Between Autarky and Interdependence, htpp://Russian-Indian_Arms_Trade:_Between_Autarky_and_Interdependence_Global_ Risk_.

Visit of the Prime Minister of the Republic of India Manmohan Singh to Moscow. December, 2011, 3.02.2012, http:// rusembindia.com/russia-india-dialogue-en/visits-and-summits/.../121-visitsandsummits/3840-visit-of-the-republic-of-india-manmohan-singh.

Zajączkowski J., Indie w stosunkach międzynarodowych, Warszawa 2008.

\section{Dokumenty w języku rosyjskim}

Совместное заявление 1971 об офиц. Визите в Индию министра иностр. дел СССР А.А. Громыко (8-12. VIII), [w:] Аипломатический словарь C-Я, t. 3, Москва 1986. 
Аоговор 1971 о мире, дружбе и сотрудничестве подиисан 9.VIII в Аели, [w:], Аипломатический словарь C-Я, t. 3, Москва 1986.

Аипломатические отношения СССР, [w:], Аипломатический словарь $А-И$, t. 1 Москва 1984.

\begin{abstract}
Abstrakt
W tym artykule, autor przedstawia i analizuje aspekty polityczne, gospodarcze i militarne współczesnych stosunków rosyjsko-indyjskich w XXI w. We wstępie artykułu zostały zarysowane najważniejsze wydarzenia w stosunkach radziecko-indyjskich, od nawiązania stosunków dyplomatycznych między Związkiem Radzieckim i Indiami w 1947 r. do upadku Związku Radzieckiego w 1991 r. Federacja Rosyjska, sukcesor Związku Radzieckiego, kontynuuje przyjazne relacje z Indiami. W pierwszej części autor koncentruje się na ewolucji stosunków politycznych, które sprowadzają się do dwóch etapów okresu prezydentury Borysa Jelcyna i prezydentury Władimira Putina, wliczając krótki okres prezydentury Dimitrija Miedwiediewa. W drugiej części analizowane są stosunki gospodarcze między obu krajami. Wśród nich handel, struktura handlowa i inwestycje. W trzeciej części skupiono się na ewolucji współpracy militarnej pomiędzy Moskwą i Delhi. W zakończeniu zostało sformułowanych kilka wniosków.
\end{abstract}

Kluczowe słowa: Federacja Rosyjska, Indie, stosunki polityczne, stosunki gospodarcze, obroty handlowe, struktura handlu, inwestycje, stosunki militarne

\begin{abstract}
In this article, the author presents and analyses political, economic and military aspects of contemporary Russian-Indian relationships in the $21^{\text {st }}$ century. In the introduction of the article the outlined most important events which took place in Soviet-Indian relationships, from establishing diplomatic relations between the Soviet Union and India in 1947 for the fall of the Soviet Union in 1991. The Russian
\end{abstract}


Federation, heir of the Soviet Union, is continuing friendly relationships with India. In the first part the author is concentrating on the evolution of political relationships, which are getting to two stages of the period presidencies of Borys Jelcyn and Vladimir Putin, including a short stretch Dimitrij Miedwiediew presidency. In the second part economic relations are being analyzed between these countries. Among them the trade, the commercial structure and investments. In the third part analysis was focused on the evolution of military relationships between Moscow and Delhi. In the end was formulated a few conclusions.

Keywords: the Russian Federation, India, political relations, economic relations, trade turnover, the commercial structure, investments, military relations 


\section{Aleksandra Czubak \\ Uniwersytet Jagielloński \\ ORCID ID: https://orcid.org/0000-0001-9052-4219}

\section{Funkcjonowania japońskich przedsiębiorstw w Polsce - uwarunkowania kulturowo-prawne}

\section{Wprowadzenie}

W dobie umiędzynarodowienia przedsiębiorstw mogłoby się wydawać, że kultura prawna nie ma dużego wpływu na funkcjonowanie międzynarodowych firm. Obserwując funkcjonowanie przedsiębiorstw można jednak zaobserwować, że kultura prawna w sposób istotny oddziałuje np. na sposób podejmowania decyzji, negocjowania i sporządzania oraz przestrzegania umów, rozumienia przepisów dotyczących prawa cywilnego czy prawa pracy. Przykładów gałęzi prawa, na których dochodzi do zetknięcia się kultur prawnych jest wiele. Różnice w kulturze prawnej i ich wpływ na funkcjonowanie $\mathrm{w}$ przedsiębiorstwie międzynarodowym są większe w przypadku narodów, które pozostają od siebie odległe także w aspekcie kultury narodowej. Przykładem takich relacji może być właśnie zetknięcie się kultury polskiej i japońskiej w środowisku biznesowym.

Aby zastanowić się nad tym w jakich obszarach japońska kultura prawna może być istotna dla prowadzenia przedsiębiorstwa z japońskim kapitałem w Polsce należy przyjrzeć 
się wartościom leżącym u podstaw tworzenia się i przestrzegania prawa w Japonii.

Prawo japońskie i prawo polskie zostało oparte na zupełnie różnych systemach wartości, jednak od XIX w. prawo europejskie zaczęło wywierać wpływ na kodyfikację japońską ${ }^{1}$. W konsekwencji sama litera prawa (zbiór norm) w Polsce i w Japonii jest podobna, natomiast stosowanie i interpretacja prawa (które jest już oparte na szerszym kontekście kulturowym, religijnym) jest zupełnie różne.

Celem niniejszego artykułu jest zarysowanie specyfiki japońskiej i polskiej kultury prawnej i prezentacja wybranych zagadnień, w których kultura prawna ma znaczenie, istotnych dla prowadzenia firmy z japońskim kapitałem w Polsce.

Świadomość znaczenia kultury prawnej pozwala bardziej wszechstronnie zrozumieć specyfikę pracy w środowisku wielokulturowym, tworzenie zasad funkcjonowania firmy, podejmowanie decyzji dotyczących jej prowadzenia oraz zawierania umów pomiędzy uczestnikami międzynarodowego obrotu handlowego.

W pierwszej części artykułu wskazane jest przybliżenie pojęcia „kultury prawnej” i omówienie, jakie ma ona znaczenie współcześnie, także w aspekcie biznesowym.

\section{Kultura prawna - pojęcie}

Aby normy prawne były rozumiane przez ogół obywateli danego kraju, powinny odpowiadać istniejącym warunkom kulturowym, społecznym i ekonomicznym. Ma to szczególne znaczenie w przypadku prawa cywilnego, prawa pracy oraz

1 L. Wolf, Japanese Law Goes Pop, „Acta Asiatica Varsoviensia” 2014, nr 27. 
prawa karnego, które to gałęzie prawa w celu efektywnego uregulowania działań obywateli muszą być spójne z etyką podzielaną przez dane społeczeństwo.

W tym kontekście bardzo trafnie termin „kultura prawna” bywa nazywany „tradycją prawną”, ponieważ wartości kształtujące tworzenie, rozumienie i przestrzeganie prawa są zakorzenione głęboko w każdym społeczeństwie. Kultura prawna jest przez socjologów prawa rozumiana przede wszystkim jako system wartości, idei oraz postaw odnoszących się do kwestii podlegających regulacji prawnej.

Mimo sięgania przy wyjaśnianiu pojęcia „kultury prawnej" do tradycji i historii należy pamiętać, że prawo oraz wartości kształtujące stosunek do prawa danego społeczeństwa podlegają ciągłej zmianie ("living law”, „law in action”) i również te aspekty należy uwzględniać przy podejmowaniu próby zrozumienia obcej kultury prawnej.

W XX w. jeden z najważniejszych myślicieli klasycznych nauk społecznych Max Weber stworzył porównawczo-kulturową socjologię prawa. W swoich rozważaniach zaznaczył, że istnieją różnice w kulturze prawa europejskiego, w szczególności pomiędzy systemem prawa cywilnego opartego na prawie stanowionym przez ustawodawcę a systemem prawa precedensowego, czyli norm ukształtowanych przez orzecznictwo sądowe. Sam termin kultura prawna nie doczekał się jeszcze jednolitej definicji.

W polskiej nauce teorii prawa oraz socjologii prawa podejmowane są próby zdefiniowania tego terminu. A. Podgórecki określa kulturę prawną jako „ogół nawyków i wartości związanych z akceptacją, oceną, krytyką i realizacją obowiązującego prawa" ${ }^{2}$ L.M. Friedman zauważa natomiast, że

2 A. Podgórecki, Prestiż prawa, Warszawa 1966, s. 179-180. 
„kultura prawna to idee, wartości, postawy i opinie odnoszących się do kwestii ludzi danego społeczeństwa w odniesieniu do prawa i systemu prawnego"3. M. Szerer z kolei kulturę prawną jako „stosunek wszystkich członków wybranej grupy społecznej do prawa"4.

W świetle powyższych definicji kulturę prawną można określić jako zauważalne $\mathrm{w}$ danym społeczeństwie (indywidualne oraz zbiorowe) postawy wobec prawa, zarówno $\mathrm{w}$ rozumieniu interpretowania i przestrzegania prawa przez poszczególne jednostki (odbiorców prawa), jak i w rozumieniu stosowania prawa i jego egzekwowania przez aparat państwowy (twórców prawa). Jednostka powinna zatem działać w granicach norm prawnych, mieć do nich szacunek i je rozumieć, a państwo powinno zapewnić jasność prawa i działać w jego granicach, nie naruszając wolności jednostki.

Inne, a zasługujące na uwagę, spojrzenie na temat kultury prawnej jest prezentowane w nauce niemieckiej ${ }^{5}$. Znaczenie i rozróżnienie przypisuje się nie tylko samej kulturze prawnej, ale również „rodzinie prawa”, która występuje w ramach danej kultury. Jak zostało wskazane, należy wyszczególnić system prawa, kulturę prawną oraz rodzinę prawną. Jeśli chodzi o kulturę prawną znaczenie dla jej wykształcenia i zdefiniowania mają takie czynniki, jak kultura narodowa, mentalność społeczeństwa, sytuacja ekonomiczna, położenie geograficzne, rozumienie świata, postrzeganie prawa i jego roli. Wszystkie te czynniki pozwalają na rozróżnienie kultur prawnych, takich jak zachodnia kultura prawna, kultura prawna islamu,

3 E. Markowska-Gos, Kultura prawna mtodzieży studenckiej. Studium socjologiczno-prawne, Rzeszów 2002, s. 32.

4 M. Szerer, Kultura i prawo, Warszawa 1981.

5 T. Kinoshita, Legal system und legal culture in Japan, „Zeitschrift für japanisches Recht” 2001, nr 11. 
indyjska kultura prawna, azjatycka kultura prawna, afrykańska kultura prawna i inne. W ramach większej kultury prawnej rozróżniana jest „rodzina prawa” i tak przykładowo azjatycka kultura prawna składa się z rodziny prawa chińskiego, rodziny prawa koreańskiego, rodziny prawa japońskiego itd. Koncept „rodziny prawnej” jest oparty o unikatowe rozróżnienie wartości prawnych występujących w ramach danych narodów.

W przypadku zachodniej kultury prawnej wyróżniane są dwa systemy prawne: system prawa cywilnego oraz prawo precedensowe. Przykładowo system prawa cywilnego dzieli się na rodzinę prawa francuskiego, rodzinę prawa niemieckiego i rodzinę prawa skandynawskiego.

Poznanie kultury i rodziny prawnej danego kraju pozwala również na przewidzenie, jakie reformy będą w danym społeczeństwie akceptowalne, a także czy dane rozwiązania prawne będą spełniać swoje cele. Znajomość kultury prawnej innego kraju w relacjach biznesowych pozawala na lepsze zrozumienie w środowisku zawodowym i bardziej świadome kierowanie firmą zagraniczną inwestującą z daleka od rynku macierzystego.

\section{Kultura prawna w Polsce i w Japonii}

Aby zrozumieć kulturę prawną Japonii należy zwrócić uwagę na to, że wyrasta ona z zupełnie innych korzeni niż kultura zachodnia. Kultura prawna Zachodu znajduje swoje źródło przede wszystkim w tradycji prawa rzymskiego, starożytnej demokracji ateńskiej oraz wartościach religii chrześcijańskiej. Kultura prawna Japonii natomiast odwołuje się do systemów religijno-filozoficznych, takich jak szintoizm, konfucjanizm oraz buddyzm. Różnice te niosą za sobą zupełnie inne rozu- 
mienie podstawowych dla danego społeczeństwa wartości, które zawarte są w takich pojęciach, jak: wina, sumienie, moralność, dobro i zło, czy wreszcie człowiek.

Kulturę prawną chrześcijaństwa charakteryzuje: religijność, dogmatyzm, humanitaryzm, integralność i powszechność. W chrześcijańskim kręgu kulturowym możemy wyróżnić podział prawa na prawo boskie (ius divinum) i prawo ludzkie (ius humanum). Prawo ludzkie jest podzielone na prawo kościelne oraz prawo państwowe. Prawo boskie natomiast dzieli się na prawo wieczne, prawo naturalne i prawo objawione zapisane w księgach Pisma Świętego ${ }^{6}$.

Religia chrześcijańska oraz niesiony przez nią system moralny ma zasadniczy wpływ na kształtowanie się polskiej kultury prawnej. Jak zauważa A. Breczko, „Na polską współczesną kulturę prawną, a co za tym idzie także na polski system prawny, ogromny wpływ wywiera w dalszym ciągu etyka chrześcijańska wraz z jej dogmatycznym charakterem, przejawiającym się w absolutyzmie i względnej niezmienności zasad. Szczególną rolę odgrywa tu oczywiście katolicyzm - jako doktryna szczególnie legalistyczna, przyjmująca obowiązywanie określonych norm i konieczność ich przestrzegania ze względu na nie same, bez każdorazowej oceny ich obiektywnej słuszności"7.

Podczas gdy wartości kształtujące europejską kulturę prawną są oparte na tradycjach chrześcijańskich, w Japonii wpływ na kształtowanie się prawa miał szintoizm, konfucjanizm i buddyzm. Wartości niesione przez wskazane systemy

6 K. Karsznicki, Główne kultury prawne na świecie, „Studia Iuridica Toruniensia” 2014.

7 A. Breczko, Wptyw wartości chrześcijańskich na polska kulture prawna i system prawa, [w:] Polska kultura prawna a proces integracji europejskiej, red. S. Wronkowska, Kraków 2005, s. 269. 
religijne i filozoficzne w znacznym stopniu determinowały rozumienie i stosowanie prawa.

Szintoizm jest religią charakteryzującą się politeizmem i wyjaśniającą porządek świata w oparciu o mitologię japońską. W religii tej nie ma klasycznej definicji pojęć dobra i zła, a bogowie - tak jak i ludzie - mają wiele oblicz. Istnieje nieskończona liczba kami (boskich duchów), począwszy od duchów w poszczególnych elementach przyrody, poprzez przodków rodziny, aż do bóstw z panteonu. Są one szczególnie cenione za honor i godność. Szintoizm również kładzie też duży nacisk na system społeczny opierający się na kooperacji i harmonii. Na tych wartościach jest zbudowane społeczeństwo w Japonii. Wartości niesione przez szintoizm są spójne z nauką konfucjańską i systemy te funkcjonują obok siebie w japońskim systemie religijno-filozoficznym.

Zgodnie z nauką konfucjanizmu, budowanie harmonijnego społeczeństwa i osiągnięcie pokoju między ludźmi jest możliwe jedynie pod warunkiem wypełniania obowiązków wynikających z hierarchii społecznej oraz poszanowania tradycji, ładu oraz porządku. Konfucjanizm przedstawia człowieka w kontekście społeczeństwa, które definiuje jako naturalne miejsce dojrzewania i kształtowania się charakteru ludzi. Konfucjusz upatrywał sensu życia człowieka, właśnie w jego umiejętności funkcjonowania w społeczeństwie. Najważniejszym środowiskiem człowieka jest jego rodzina, wobec której należy okazywać należny szacunek. Zgodnie z myślą Konfucjusza relacje i układy panujące w rodzinie powinny być przenoszone na strukturę państwa, a aktualnie te wartości są dostrzegane właśnie w strukturze działania firm. Przestrzeganie opisanych wartości i osiągnięcie harmonii w ramach przedsiębiorstwa, kolektywne podejmowanie decyzji w oparciu o ogólny konsensus i aprobatę przeło- 
żonych usytuowanych w odpowiedniej hierarchii w firmie stanowi wartości widoczne w japońskiej firmie. Te wartości, wynikające właśnie z konfucjanizmu, częściowo determinują funkcjonowanie firmy i współpracę z partnerami zagranicznymi, a w konsekwencji są nadal aktualne w systemie funkcjonowania współczesnego społeczeństwa.

Charakterystycznymi ideałami ludzkiego charakteru zawartymi natomiast w buddyzmie jest cnota, panowanie nad sobą, myślenie wolne od żądzy, nieżyczliwości i gwałtowności, spokój, skupienie oraz radość. Etyka buddyjska mówi, że charakter czynu ludzkiego jest nierozłącznie związany z intencją. Czyny, które są następstwem dobrych intencji powodują pozytywne skutki zarówno dla jednostki, jak i dla społeczeństwa.

Opisane ideologie, kładące nacisk na ochronę oraz rozwój interesu społecznego, a nie indywidualnego, ukształtowały kardynalne zasady prawa i kształtują także normy wpływające na jego interpretowanie. W Japonii, w przeciwieństwie do wartości zakorzenionych w świecie zachodnim, najważniejsza jest grupa. Jedynie bierne podporządkowanie się niezmiennemu stanowi rzeczy, w którym określone osoby zajmują konkretne pozycje społeczne, może doprowadzić do wytworzenia poczucia harmonii, a tym samym pożądanego stanu, chronionego przez prawo. Harmonia, do której dąży japońskie społeczeństwo, nie polega więc na uzgadnianiu sprzecznych interesów różnych indywidualnych jednostek, lecz na ochronie interesu ogółu ${ }^{8}$.

Jeśli chodzi o sam system japońskiego prawa, początkowo japońska kultura prawna była tworzona przede wszyst-

8 I.C Kamiński, Stuszność i prawo - szkic prawnopowównawczy, Kraków 2003, s. 192. 
kim przez wewnętrzne zasady prawa zwyczajowego. Prawo to jest obecne na przestrzeni całej historii japońskiej kodyfikacji. W VII w. prawo japońskie zaczęło kształtować się w oparciu o wpływy chińskie i zbiór regulacji dotyczących prawa karnego i administracyjnego został oparty o kodyfikacje chińską: ristu-ryo.

Kodeks ritsu-ryo, jako implementowany do wewnętrznych przepisów prawnych z chińskiego systemu prawnego, nie był jednak spójny z japońskim prawem zwyczajowym, kulturą oraz mentalnością. W związku z tym kodeks był modyfikowany, a jego oficjalne uzupełnienie miało miejsce w 745 r. i zostało nazwane kodeksem Yörō-ritsury $\bar{o}^{9}$.

Na przestrzeni kolejnych wieków ritsu-ryo było w praktyce zastępowane prawem zwyczajowym. Litera prawa stanowionego była oficjalną podstawą prawa, jednak w praktyce nie była ona stosowana, a relacje prawne były oparte o ustaloną tradycję i zwyczaj. Przykładem prawa zwyczajowego jest kodeks samurajski bushidō. Dodatkowo, mimo że prawo oparte było głównie o tradycję i zwyczaj, postanowiono spisać część funkcjonujących zwyczajowo zasad w formie Kodeksu Jōei w 1232 r. Kodeks ten stanowił pierwszy etap kodyfikacji prawa zwyczajowego w Japonii i liczył 51 artykułów. Celem tego kodeksu była regulacja stosunków pomiędzy samurajami, a także ochrona obiektów religijnych.

Prawo rozwijało się spokojnie i harmonijnie, lecz w czasach Tokugawa powstało kilka kodeksów, regulujących restrykcyjnie kwestie napływających do Japonii obcokrajowców, uznawanych przez szogunów za potencjalnych kolonizatorów, których należy się obawiać. Przepisy, które weszły w życie w okresie Tokugawa, zabraniające kontaktu

9 A. Kość, Filozoficzne podstawy prawa japońskiego w perspektywie historycznej, Lublin 2001, s. 60. 
z cudzoziemcami (w tym w dużej mierze handlu z Europejczykami) zamknęły Japonię na świat zewnętrzny na ponad 250 lat.

Przełomowa karta historii japońskiego prawa rozpoczęła się wraz z rewolucją Meiji (1868-1912), gdy rząd zadecydował, że dla zachowania niepodległości państwa konieczne jest przeprowadzenie dogłębnych reform. Przystąpiono do unowocześnienia dotychczasowych struktur społeczno-politycznych w kraju. Jak zostało już wspomniane, to właśnie 1868 r. wiązał się z narodzeniem słowa kenri, służącego do opisywania prawa w rozumieniu zachodnim. Europejski sposób myślenia, zawarty w normach prawnych, nie odpowiadał jednak do końca mentalności japońskiej. Dlatego Japończycy, niezależnie od recypowania prawa europejskiego, rozwijali swoje reguły postępowania, mające na celu utrzymanie bezkonfliktowego funkcjonowania społeczeństwa.

Po II wojnie światowej, w okresie okupacji amerykańskiej, Japonia dokonała natomiast recepcji prawa amerykańskiego. Wobec tego aktualny model prawny w Japonii ma charakter hybrydowy, zawierający elementy prawa europejskiego (civil law) oraz amerykańskiego (common law). Dodatkowo, na kształt japońskiego prawa, sposób jego interpretowania i rozumienia nadal ma wpływ filozofia konfucjańska, właściwa dla systemu etycznego wielu państw azjatyckich i wpływająca na kulturę prawną.

Długo przed przyjęciem zasad prawa europejskiego, Japończycy wypracowali normy społeczne, które do dnia dzisiejszego kierują ich życiem. Reguły te nie miały charakteru prawnego, ale moralny i zostały do porządku prawnego wdrożone. Zwyczajowe reguły odgrywają w życiu Japończyków niezwykle ważną rolę. Tradycyjne zasady postępowania, które przestrzegane są w Japonii bardziej restrykcyjnie niż 
prawo, nazywane są regułami giri. Prawidłowe zachowanie zakorzenione jest więc znacznie głębiej, niż jedynie w chęci uniknięcia doczesnej kary. Jest ono związane bowiem z głębokimi wartościami pielęgnowanymi przez wieki. Na termin giri składają się dwa chińskie znaki, gi oznaczający słuszność, sprawiedliwość oraz ri oznaczający rozum, rozsądne zachowanie $^{10}$. Giri najczęściej tłumaczone jest jako „moralna powinność”. Wspomniana „powinność” określonego zachowania wobec innych osób nie wynika zatem jedynie z norm prawnych, które mówią, że za nieprawidłowe zachowanie przewidziana jest kara, ale związana jest także z kultywowaną od wieków tradycją. Giri jest więc rozumiane jako swoisty obowiązek wdzięczności wobec innych. Można tu podać przykład giri uczniaw stosunku do nauczyciela czy giri dziecka w stosunku do rodziców. Ten obowiązek wdzięczności przejawiany wobec innych powinien być wyrażany w konkretnych czynach.

Japoński system prawa podlegał zmianom na przestrzeni wieków. Od rodzimej japońskiej tradycji, kształtującej normy prawne oparte na japońskim prawie zwyczajowym poprzez wpływy chińskie, a następne europejskie i amerykańskie doprowadził do systemu łączącego elementy zagranicznych kultur prawnych z kulturą prawa japońskiego, stanowiącego bazę i podstawę interpretacji prawa implementowanego. W konsekwencji współczesna kultura prawna jest słusznie przez Tsuyoshi Kinoshita opisana jako kultura położona gdzieś pomiędzy zachodnią kulturą prawną a japońską kulturą prawną. Wskazuje on także, że bezpieczniej powiedzieć można, że japońskie prawo jest systemem hybrydowym łączącym cechy zachodniej kultury prawnej

10 Ibidem, s. 175. 
$\mathrm{z}$ tradycyjnym systemem prawa japońskiego ${ }^{11}$. Kinoshita podkreśla, że błędem jest określanie japońskiego sytemu prawnego mianem orientalnej kultury prawnej i wskazywanie, że jego współczesny kształt jest oparty jedynie na europejskich i amerykańskich źródłach prawa, podkreślając, że „to prawda, że japońskie prawo zostało ukształtowane przez systemy prawa zachodniego, ale to nigdy nie było i nie jest "prawo zachodnie «"12.

Na uwagę zasługuje pogląd Jiro Kamashima, że kultura narodowa i wrodzona mentalność danego społeczeństwa determinuje koncepcje prawa i co za tym idzie wpływa na dostosowanie implementowanego prawa do mentalności i kultury danej narodowości ${ }^{13}$.

\section{Znaczenie kultury prawnej dla przedsiębiorstwa zagranicznego}

Coraz większy przepływ zasobów ludzkich wynikający z otwarcia się gospodarek świata spowodował mieszanie się kultur w środowisku biznesowym. Od ponad dwudziestu lat w Polsce działają również przedsiębiorstwa japońskie, które tworzą w Polsce wiele miejsc pracy i są miejscem zetknięcia się kultur prawnych pozwalających przenieść opisaną wcześniej teorię dotyczącą japońskich wartości prawnych także na grunt polski.

Aspekty kulturowe odgrywają istotną rolę w zarządzaniu przedsiębiorstwem z japońskim kapitałem w Polsce i mogą

11 T. Kinoshita, Legal system und legal culture in Japan, „Zeitschrift für japanisches Recht” 2001, nr 11.

12 Ibidem, s. 35.

13 Ibidem, s. 32. 
doprowadzić do nieporozumień i dystansu pomiędzy osobami delegowanymi do pracy a pracownikami lokalnymi, w tym także miejscową kadrą menadżerską czy wreszcie pomiędzy Japończykami a lokalnymi kontrahentami. Dystans ten jest zjawiskiem często spotykanym podczas wchodzenia firm na rynek zagraniczny i może on wynikać na przykład $\mathrm{z}$ barier kulturowo prawnych, komunikacyjnych czy organizacyjnych. Różnice kulturowo prawne w firmie składającej się z przedstawicieli japońskich i polskich mogą być dostrzegalne w stylu negocjacji, rozumieniu prawa pracy, zapisach prawa cywilnego, jak również w samej strukturze organizacyjnej firmy czy sposobie zarządzania.

Zagadnienia kulturowo prawne mają istotne znaczenie dla japońskiej firmy wchodzącej na polski rynek. Przede wszystkim wynika to $\mathrm{z}$ opisanych różnic $\mathrm{w}$ wartościach leżących w podstaw tworzenia się prawa, sposobie jego interpretowania i wadze jego przestrzegania. Kultura prawa determinuje np. sposób prowadzenia negocjacji czy zawierania umów i metod rozwiązywania sporów. W wielu przypadkach wyjaśnienia rozbieżności w kulturze prawnej można szukać w tradycji, np. systemie filozoficzno-religijnym Japonii oraz poznając proces kształtowania się japońskiego prawa. Różnice w kulturze prawnej, istotne z perspektywy firmy z japońskim kapitałem w Polsce, dotyczą przede wszystkim zagadnień związanych z prawem cywilnym, gdzie za przykład można podać odmienności w sporządzaniu kontraktów, które w Japonii są dużo mniej wyczerpujące i sformalizowane. Odejście od bardzo podstawowej formy umów zawierającej i przygotowywanie umów zawierających postanowienia dotyczące wszelkich aspektów danej czynności prawnej stało się powszechne dopiero wobec wzrostu współpracy międzynarodowej. Innym przykładem 
są różnice w sposobie podejmowania decyzji dotyczących np. zawarcia umowy, gdyż decyzje takie są podejmowane w sposób kolektywny, co ma swoje źródło m.in. w zasadach konfucjańskich. Kolejnym przykładem z zakresu umów może stać się brak powszechności zapisu dotyczącego sposobu rozwiązywania sporów (np. zapisu na sąd arbitrażowy) wobec niechęci Japończyków do wkraczania na drogę sądową, co również można tłumaczyć kulturowymi czynnikami, takim jak niechęć przed utartą twarzy czy skompromitowania się przed grupą. Jak było wskazane w artykule, jedną z najwyższych cnót w Japonii jest harmonia społeczna zabezpieczająca interes grupy. Chęć zachowania nieustającej harmonii i związane z tym unikanie konfliktów sprawia, że Japończycy nie preferują występowania ze swoimi roszczeniami przed sądem. Sprawa sądowa oznacza wejście w konflikt, w dodatku o charakterze publicznym. W związku z tym, że Japończycy unikają sporów sądowych, bardzo popularna jest w Japonii koncyliacja. Dzięki niej Japończycy mogą uzyskać rozwiązanie problemu, które w sposób wyważony uwzględniać będzie interesy obu stron ${ }^{14}$. Sposób osiągnięcia porozumienia za pomocą koncyliacji może być przeprowadzany przez różne osoby, odmiennymi sposobami, w zależności od indywidualnych predyspozycji stron (za pomocą negocjacji, przekonywania oraz dyskusji). Odmienności spotykane są w dużej mierze w zakresie prawa pracy, gdzie również kultura narodowa determinuje sposób przestrzegania prawa i regulacji w tym zakresie, zwłaszcza w kontekście kulturowego podejścia do samego etosu pracy. Przykłady można mnożyć, ale świadczą one o tym, że nawet pomimo, że prawo stanowione w obu państwach jest bardzo

14 A. Kość, Filozoficzne podstawy prawa japońskiego w perspektywie historycznej, Lublin 2001, s. 179. 
podobne, to jego stosowanie i interpretacja jest oparta na innych normach i wartościach kulturowych.

Powyższa charakterystyka ukazuje ogromną różnicę pomiędzy podejściem do prawa Japończyków i ludzi z Zachodu. Aby zrozumieć japoński punkt widzenia należy badać nie tylko miejscowe akty prawne i literaturę prawniczą, ale przede wszystkim analizować japońskie wzorce zachowania i kulturę prawną.

Różnice w kulturze prawnej stwarzają wyzwania, których warto być świadomym i które należy wziąć pod uwagę rozważając o funkcjonowaniu japońskiego przedsiębiorstwa w Polsce. W konsekwencji poza koniecznością spełnienia formalnych przesłanek wynikających ustaw czy zawarcia w umowach konkretnych zapisów należy upewnić się, że czynności te zostaną właściwie zrozumiane przez współpracujących w ramach przedsiębiorstwa Japończyków.

\section{Bibliografia}

Breczko A., Wptyw wartości chrześcijańskich na polska kulture prawna i system prawa, [w:] Polska kultura prawna a proces integracji europejskiej, red. S. Wronkowska, Kraków 2005.

Kamiński I.C., Stuszność i prawo - szkic prawnopowównawczy, Kraków 2003.

Karsznicki K., Główne kultury prawne na świecie, „Studia Iuridica Toruniensia" 2014.

Kinoshita T., Legal system und legal culture in Japan, „Zeitschrift für japanisches Recht" 2001, nr 11.

Kość A., Filozoficzne podstawy prawa japońskiego w perspektywie historycznej, Lublin 2001. 
Markowska-Gos E., Kultura prawna młodzieży studenckiej. Studium socjologiczno-prawne, Rzeszów 2002.

Podgórecki A., Prestiż prawa, Warszawa 1966.

Szerer M., Kultura i prawo, Warszawa 1981.

Wolf L., Japanese Law Goes Pop, „Acta Asiatica Varsoviensia" 2014, nr 27.

\begin{abstract}
Abstrakt
Celem niniejszego artykułu jest przedstawienie tematu zetknięcia kultur prawnych w polsko-japońskim środowisku pracy.

Prawo japońskie i prawo polskie zostało oparte na zupełnie różnych systemach wartości, jednak od XIX w. prawo europejskie zaczęło wywierać wpływ na kodyfikację japońską. W konsekwencji normy obowiązujące w Polsce i w Japonii są podobne, natomiast stosowanie i interpretacja prawa, które jest już oparte na szerszym kontekście kulturowym, religijnym, jest zupełnie różna. Artykuł zarysowuje problematykę wskazanych różnic w kulturze prawnej, zaznaczając obszary prawa, w których różnice w jego interpretowaniu mogą odgrywać istotną rolę i przedstawia kontekst historyczny oraz te wartości kulturowe i religijne, które mają znaczenie dla aktualnego kształtu japońskiej kultury prawnej.
\end{abstract}

Słowa kluczowe: japońska kultura prawna, japońskie przedsiębiorstwa w Polsce

\begin{abstract}
The main goal of this article is to present the clash of legal cultures in the Polish-Japanese work environment.

Japanese law and Polish law were based on two completely different value systems, but from the $19^{\text {th }}$ century European law has begun to influence Japanese codification. Consequently, the letter of the law (set of norms) in Poland and Japan is similar, but the application and interpretation of it (which is already based on a broader cultural and religious context) is different.
\end{abstract}


The article outlines the issues of the indicated differences in legal culture, marking the areas of law in which the differences may play an important role and presents the historical context as well as those cultural and religious values that are important for the current shape of Japanese legal culture.

Keywords: Legal culture, Japanese legal culture, Japanese companies in Poland 


\section{Eukasz B. Pilarz}

Uniwersytet Śląski w Katowicach

ORCID ID: https://orcid.org/0000-0003-4138-9211

\section{Recycling statków a ochrona środowiska wód morskich na przykładzie stoczni złomowych w Indiach i Bangladeszu}

\section{Wprowadzenie}

Jednym z największych problemów w dziedzinie gospodarki odpadami, z jakim boryka się ochrona środowiska morskiego jest recykling statków i odzysk materiałów, z których zbudowane są statki. W ostatnich latach problem złomowania starych, wyłączonych już z eksploatacji i niespełniających norm dużych statków morskich urósł do rozmiarów rozważanych na skalę światową. Świadczy o tym duża ilość wyspecjalizowanych stoczni złomowych, w których zalegają wraki statków, oczekując na pełną rozbiórkę. Zalegające statki stanowią z jednej strony źródło zanieczyszczenia dla okolicznych wód morskich poprzez wydobywanie się z doków stoczniowych resztek paliwa, olejów, smarów, chemikaliów substancji radioaktywnych z instalacji statków. Z drugiej z kolei strony stają się źródłem niebezpiecznych odpadów złomowych. Stocznie złomowe, jak z samej nazwy wynika, zajmują się rozbiórką i cięciem na złom jednostek pływających. Większość z nich jest obecnie usytuowana w krajach, takich jak Indie, Bangladesz i Birma, gdzie zwraca się mało uwagi na 
ochronę środowiska morskiego. Dodatkowym czynnikiem sprzyjającym w tych państwach jest tania siła robocza. Ma to duże znaczenie, gdyż złomowanie statku wymaga dużej ilości pracy ręcznej, trudnej do zmechanizowania i automatyzacji. Państwa Azji Południowo-Wschodniej (odnosi się to przede wszystkim do Indii i Bangladeszu) przodują w tym zakresie. Azja w złomowaniu statków zajmuje pierwsze miejsce na świecie. W Europie jest to Turcja. W samej Unii Europejskiej nie spotyka się tego rodzaju działalności z powodu dużych kosztów rozbiórki i złomowania, potrzebnych dużych nakładów pracy przekładających się w ostatecznie w porównaniu na małe zyski ze sprzedaży złomu, gdzie w obrębie Unii jest to słabo opłacalny biznes. Z kolei w krajach Azji jest dokładnie na odwrót. Działalność w tej branży rozwija się w zawrotnym tempie. Ocenia się, że ponad 80\% wszystkich statków ze świata jest złomowanych właśnie w państwach azjatyckich. Przemawiają za tym czynniki: słabo rozwinięte przepisy ochrony środowiska; duża ilość taniej siły roboczej (ludzie pracujący przy złomowaniu pracują w warunkach szczególnie niebezpiecznych, są narażeni na działanie szkodliwych substancji i chemikaliów). Ocenia się, że w stoczniach, co miesiąc ginie około 30 osób, co w skali roku daje bardzo dużą ilość. Przy pracy nieprzestrzegane są podstawowe przepisy bezpieczeństwa i higieny pracy. Trzeci czynnik wpływający na opłacalność tego typu działalności gospodarczej to wysokie ceny za sprzedaż głównie złomowanej stali ${ }^{1}$.

Działania zmierzające do zapobiegania zwiększającego się procederu złomowania i recyklingu statków (prowadzonego na plażach wybrzeży Indii doprowadzają do zanieczyszczenia i degradacji środowiska) podjęła Międzynarodowa Organi-

1 Por. W. Radecki, Prawo ochrony środowiska. Wybrane problemy, Warszawa 2010, s. 67. 
zacja Morska (IMO) i Międzynarodowa Organizacja Pracy (ILO). IMO MEPC porusza kwestię recyklingu statków, ustala zasady procesu przygotowywania statku do złomowania, skoordynowanie zasad współpracy z Międzynarodową Organizacją Pracy i konwencja bazylejską ${ }^{2}$. Ponadto MEPC uzgodniło powstanie nowej konwencji dotyczącej recyklingu statków z zamiarem stworzenia prawnie obowiązujących globalnych przepisów dla przemysłu okrętowego i stoczni złomowych. Z kolei w 2005 r. IMO uchwaliła rezolucję A.981(24) o nowej Konwencji dotyczącej złomowania i jej przyjęciu na przełomie lat 2008 i 2009. IMO współpracuje z Międzynarodową Organizacją Pracy (ILO) oraz państwami-stronami konwencji bazylejskiej w sprawach odnoszących się recyklingu. Wyrazem tej kooperacji na poziomie międzynarodowym jest ustanowienie przez te trzy organizacje Wspólnej Grupy Roboczej IMO/IOL/BC do spraw Bezpiecznego i Ekologicznego Złomowania Statków. Konwencja bazylejska z 1989 r. o kontroli transgranicznego przemieszczania i usuwania odpadów niebezpiecznych nie spełniła swojego zadania, przynajmniej w stosunku do statków kierowanych do złomowania, zwłaszcza biorąc pod uwagę fakt, iż przyjęta w 1995 r. poprawka (tzw. Basel Ban Amendment) zakazująca eksportu odpadów z państw OECD do państw rozwijających się do dziś nie została ratyfikowana przez wystarczającą liczbę państw i w konsekwencji nie weszła w życie. Konwencja ma uregulować sprawy związane z projektowaniem, konstrukcją, eksploatacją i przygotowywaniem statków w celu ułatwienia ich późniejszego bezpiecznego i przyjaznego dla środowiska recyklingu, bez kompromisu w dziedzinie ich bezpieczeń-

2 Konwencja bazylejska z 1989 r. o kontroli transgranicznego przemieszczania i usuwania odpadów niebezpiecznych, tekst dostępny na stronie: www.imo.org. 
stwa i wydajności operacyjnej (tzw. formuła - statku łatwego do rozbiórki i złomowania, proces przygotowania statku do recyklingu, listy - inwentarze materiałów niebezpiecznych użytych na statku i kontrolowanych przez konwencję); ułatwieniem prowadzenia recyklingu w bezpieczny i przyjazny dla środowiska sposób - przepisy dla stoczni złomowych; ustanowieniem odpowiednich mechanizmów recyklingu statków (przeglądy i ich poświadczanie, standardowe formaty świadectw dla statków, wymagania raportowania itd.). Prowadzony ma być inwentarz materiałów niebezpiecznych. Ma to być dokładna informacja o lokalizacji i ilościach potencjalnie niebezpiecznych materiałów na pokładzie statku, tak aby ochronić zdrowie i bezpieczeństwo pracowników, jak też w celu zapobiegnięciu zanieczyszczenia środowiska podczas złomowania. Konwencja dotyczy statków od 500 ton pojemności brutto ${ }^{3}$. Z kolei przyjęta w Hongkongu Konwencja o bezpiecznym i ekologicznym recyklingu statków postawiła przed przedsiębiorcami prowadzącymi rozbiórkę statków wiele wymogów, po spełnieniu których będą się oni mogli ubiegać o wpisanie na listę autoryzowanych stoczni złomowych, a nadto uregulowała kwestię substancji niebezpiecznych znajdujących się na statku. Podobne zabiegi wcześniej wprowadziła Unia Europejska4. Jak wielka jest skala zjawiska

3 Statki żeglugi krajowej nie powinny być wykluczone od stosowania konwencji, gdyż mogłoby to stworzyć wybieg dla niektórych statków w celu uniknięcia konieczności spełnienia wymagań konwencji. Konwencja nie będzie dotyczyć tych statków żeglugi krajowej, które będą złomowane w kraju. IMO, ILO i konwencja bazylejska podjęły działania w celu rozwinięcia realistycznego i efektywnego rozwiązania problemu recyklingu statków poprzez stworzenie wspólnej grupy roboczej w celu stworzenia konwencji.

430 grudnia 2013 r. weszło w życie rozporządzenie Parlamentu Europejskiego i Rady 1257/2013 o złomowaniu statków i zmianie rozporządzenia (WE) 1013/2006 oraz dyrektywy 2009/16/WE, które wprowadza szereg istotnych zmian w dotychczasowym sposobie gospodarowania 
złomowania statków perspektywie obecnej i przyszłej pokazuje treść zielonej księgi UE w sprawie lepszych warunków demontażu statków. W tej grupie statków zawarta jest również wcale nie mała grupa statków i okrętów wojskowych, które w najbliższym czasie zostaną wycofane ze służby.

\section{Pojęcie zanieczyszczenia}

Rzeczownik „zanieczyszczenie” występuje w języku powszechnym w kilku znaczeniach. Pierwsze z nich to określenie czynności, utworzone od czasownika „zanieczyścić”. W innym znaczeniu zanieczyszczenie oznacza „to, co zanieczyszcza: odpadki, brud, śmiecie, domieszkę obcej substancji”. Wspomnianego rzeczownika używa się również dla oznaczenia określonego stanu rzeczy - przede wszystkim stanu, w jakim znajduje się środowisko naturalne lub któryś z jego elementów. Zanieczyszczenie środowiska przyrodniczego w ostatnim z wymienionych znaczeń definiuje się jako „stan środowiska wynikający z wprowadzenia do powietrza, wody lub gruntu albo nagromadzenia na powierzchni ziemi substancji stałych ciekłych lub gazowych". Owo wprowadzenie albo nagromadzenie stanowi natomiast nic innego jak wspomnianą czynność (pierwsze z podanych znaczeń rzeczownika „zanieczyszczenie") $)^{5}$.

jednostkami wycofywanymi z eksploatacji (dokument został w czerwcu 2013 r. pozytywnie zaopiniowany przez Komisję Ochrony Środowiska Naturalnego, Zdrowia Publicznego i Bezpieczeństwa Żywności (ENVI), by w październiku 2013 r. rozporządzenie oficjalnie przyjęto na posiedzeniu plenarnym PE, http://www.promare.pl/index.php/component/ content/article/245-pl/archiwum-wiadomosci/raport/raport-2014/namiary-na-morze-i-handel-nr-02-2014/740-unijne-zlomowanie?lang=pl. D. Szymankiewicz, P. Jędrusiak, Unijne złomowanie [dostęp: 12.05.2020].

5 Por. D. Pyć, Prawo Oceanu Światowego. Res usus publicum, Gdańsk 2011, s. 138. 
W nauce mówi się o występowaniu zanieczyszczeń w glebie, wodzie czy też powietrzu, gdy ich skład odbiega od naturalnego. I tak „za zanieczyszczenie należy uznać wszystkie składniki, które zniekształcają naturalny skład powietrza

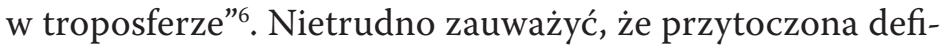
nicja jest bardzo szeroka. Nieco węższa - w odniesieniu do zanieczyszczeń powietrza - jest definicja, która zalicza do nich „gazy, ciecze i ciała stałe obecne w powietrzu, niebędące jego naturalnymi składnikami, lub też substancje występujące w ilościach wyraźnie zwiększonych w porównaniu z naturalnym składem powietrza". Zakres zastosowania omawianego pojęcia ograniczono zatem do sytuacji, gdy wspomniane substancje występują w powietrzu w ilościach „wyraźnie” zwiększonych. Oczywiście, podane kryterium jest nieostre ${ }^{7}$. Warto zauważyć, że nie użyto go w definicji zanieczyszczeń wód, które określono jako „substancje chemiczne, bakterie i inne mikroorganizmy, obecne w wodach naturalnych w zwiększonej ilości”8.

Legalna definicja z jednej strony zawęża zakres stosowania pojęcia zanieczyszczenia do przypadków możliwości

6 Por. E. Sobol (red.), Nowy słownik języka polskiego, Warszawa 2002, s. 123.

7 Por. R. Zarzycki, Aerosfera - źródta i rodzaje zanieczyszczeń, sposoby jej ochrony, [w:] Ekologia. Jej związki z różnymi dziedzinami wiedzy, red. A. Kurnatowska, Warszawa-Łódź 1997, s. 12.

8 Inaczej zdefiniowano zanieczyszczenie (w znaczeniu przedmiotowym) w ustawie z dnia 27 kwietnia 2001 r. Prawo ochrony środowiska - akt ten określa je w art. 3 pkt 49 jako „emisję, która może być szkodliwa dla zdrowia ludzi lub stanu środowiska, może powodować szkodę w dobrach materialnych, może pogarszać walory estetyczne środowiska lub może kolidować z innymi, uzasadnionymi sposobami korzystania ze środowiska”. Emisja to zaś - w myśl art. 3 pkt 4 ustawy - „wprowadzane bezpośrednio lub pośrednio, w wyniku działalności człowieka, do powietrza, wody, gleby lub ziemi: a) substancje, b) energie, takie jak ciepło, hałas, wibracje lub pola elektromagnetyczne". 
wystąpienia określonych szkód czy też kolizji z „uzasadnionymi sposobami korzystania ze środowiska”. Z drugiej strony w sposób wyraźny rozciąga je na różnego rodzaju energie, które nierzadko w stopniu większym niż substancje zagrażać mogą środowisku.

Innym terminem jest pojęcie „wytwórcy odpadów”, czyli każdego, którego działalność lub bytowanie powoduje powstawanie odpadów (pierwotny wytwórca odpadów), oraz każdego, kto przeprowadza wstępną obróbkę, mieszanie lub inne działania powodujące zmianę charakteru lub składu tych odpadów. Wytwórcą odpadów powstających w wyniku świadczenia usług w zakresie budowy, rozbiórki, remontu obiektów, czyszczenia zbiorników lub urządzeń oraz sprzątania, konserwacji i napraw jest podmiot, który świadczy usługę, chyba że umowa o świadczenie usługi stanowi inaczej $^{9}$. Z kolei przez „gospodarowanie odpadami” rozumie się zbieranie, transport, przetwarzanie odpadów, łącznie z nadzorem nad tego rodzaju działaniami, jak również późniejsze postępowanie z miejscami unieszkodliwiania odpadów oraz działania wykonywane w charakterze sprzedawcy odpadów lub pośrednika w obrocie odpadami. Odrębnie zdefiniować też należy „zbieranie odpadów” i „przetwarzanie odpadów”. Przez „zbieranie odpadów” rozumie się gromadzenie odpadów przed ich transportem do miejsc przetwarzania, w tym wstępne sortowanie nieprowadzące do zasadniczej zmiany charakteru i składu odpadów i niepowodujące zmiany klasyfikacji odpadów oraz tymczasowe magazynowanie odpadów ${ }^{10}$. Natomiast przez „przetwarzanie odpadów” rozumie

9 Por. art. 3 ust. 1 pkt 32 ustawy z dnia 14 grudnia 2012 r. o odpadach (dalej powoływana jako UO).

10 Por. art. 3 ust. 1 pkt 34 UO. 
się procesy odzysku lub unieszkodliwiania, $w$ tym przygotowanie poprzedzające odzysk lub unieszkodliwianie ${ }^{11}$.

\section{Rodzaje zanieczyszczeń}

Zanieczyszczenia wody morskiej mogą być różnego pochodzenia. Te najbardziej niebezpieczne i stanowiące największe szkody i zagrożenie dla życia biologicznego to zanieczyszczenia ciekłe. Zaliczamy do nich przede wszystkim paliwa płynne, na czele z ropą naftową ${ }^{12}$. Od kilkudziesięciu lat paliwo płynne otrzymywane z ropy naftowej w coraz większym stopniu stosowane jest zamiast węgla do celów energetycznych oraz jako podstawowy surowiec w przemyśle chemicznym $^{13}$. W związku z tym olbrzymie ilości ropy, olejów i benzyny transportuje się drogą morską. Zanieczyszczenie wód morskich pochodzące $\mathrm{z}$ transportu spowodowane jest usuwaniem do wody wszelkich odpadków olejowych podczas pracy statków oraz myciem tankowców, które zwykle odbywa się na morzu. Oblicza się, że zanieczyszczenie z tych źródeł znacznie przekracza ilości pochodzące z różnych wypadków morskich, łącznie z katastrofami tankowców ${ }^{14}$. W stosunku do ogólnej masy wód oceanów obecne zanieczyszczenie ropą i olejami nie jest groźne. Oleje są usuwane z wody w wyniku różnych procesów naturalnych, których skuteczność zależy od następujących czynników: temperatury, światła słonecz-

11 Zgodnie z art. 3 ust. 1 pkt 21 UO.

12 Por. M. Górski, A. Barczak, D. Jakubowska, A. Jaworowicz-Rudolf, A. Kaźmierska-Patryczna, J. Kierzkowska, P. Korzeniowski, J. Miłkowska (red.), Prawo ochrony środowiska, Warszawa 2009.

13 Por. W. Radecki, Prawo ochrony środowiska..., op.cit., s . 67.

14 Por. S. Depowski, R. Kotliński, E. Rühle, K. Szamałek (red.), Surowce mineralne mórz i oceanów, Warszawa1998. 
nego, szybkości wiatru, wysokości fali, rodzaju i ilości bakterii w wodzie oraz składu chemicznego oleju, jego ciężaru właściwego, stopnia oczyszczenia itp. Olej wylany do wody szybko rozpościera się na jej powierzchni w postaci bardzo cienkiej warstwy $^{15}$. Obecne w ropie naftowej kwasy i sole nieorganiczne ulegają rozpuszczeniu, a pozostała część oleju zemulgowaniu. Możliwe jest wytworzenie dwóch rodzajów emulsji: oleju w wodzie i wody w oleju. Emulsje pierwszego rodzaju mieszają się z wodą i dzięki temu ulegają dużej dyspersji. Drugi rodzaj pozostaje na powierzchni dopóki nie zwiększy się jego gęstość i nie opadnie na dno. Dyspersja oleju w wodzie jest etapem poprzedzającym jego utlenianie. Rozróżnia się dwa typy utleniania: autooksydację, która zachodzi pod wpływem tlenu i światła słonecznego oraz utlenianie mikrobiologiczne. Utlenianie mikrobiologiczne jest najważniejszym procesem w oczyszczaniu wód od zanieczyszczeń olejami. Obliczono uwzględniając tylko 1/3 ogólnej powierzchni oceanów i głębokość od $10 \mathrm{~m}$ jako strefę biologicznie czynną, że co najmniej 1011 ton oleju rocznie może ulec degradacji mikrobiologicznej. Sytuacja przedstawia się inaczej, gdy zostaną zanieczyszczone wody przybrzeżne lub gdy kierunek przeważających w danym rejonie wiatrów znosi warstwy oleju na ląd. Wówczas mogą ulec uszkodzeniu instalacje przybrzeżne, zanieczyszczone zostają porty, plaże i miejscowości wypoczynkowe. W takich wypadkach ginie zwykle wiele ptaków i organizmów wodnych ${ }^{16}$.

W zależności od regionu świata możemy mieć do czynienia z różnego rodzaju zanieczyszczeniami. Wśród nich mogą

15 Por. M. Drogosiewicz, J. Nowakowski, Eksploatacja statku handlowego, Gdynia 2000.

16 Por. J. Kubicki, Ekonomika i organizacja transportu morskiego, cz. I: Organizacja transportu morskiego, Gdynia 1992, s. 102. 
być regiony, gdzie zatapianie odpadów ma charakter celowy, gdyż wynika to $\mathrm{z}$ faktu, iż na terenach lądowych składowanie tych odpadów z różnych względów staje się niebezpieczne, niemożliwe, zabronione lub po prostu zbyt kosztowne. Z kolei inni autorzy zwracają ponadto uwagę na coraz częstszy proceder oczyszczania tankowców w wodach oceanicznych ${ }^{17}$. W końcu należy także uwzględnić niezależne od nas przypadki losowe kolizji jednostek pływających przewożących materiały czy płynny zanieczyszczające, ze szczególnym uwzględnieniem tankowców i chemikaliowców ${ }^{18}$.

Zadaniem statutowym EMSA jest również monitorowanie i śledzenie statków, które świadomie i celowo dopuszczają się deliktów zanieczyszczenia wód morskich. Na wypadek znacznego rozlania ropy na morzu utworzona została specjalna flota statków, które mają za zadanie udzielenie pomocy państwom członkowskim, do których jurysdykcji przynależą wody, na których doszło do rozlania i zanieczyszczenia ${ }^{19}$. Jednocześnie istnieje możliwość zidentyfikowania statku doko-

17 Por. J. Kujawa, Organizacja i technika transportu morskiego, Gdańsk 2005, s. 67.

18 Por. L. Plewiński, Wypadki na morzu, Szczecin 2000. Źródła zanieczyszczeń wg danych EMSA najczęściej mają charakter typowo bezprawny. Można tutaj zaliczyć przede wszystkim zrzuty odpadów olejowych z maszynowni lub ścieków powstających podczas mycia zbiorników. Wiele takich procederów, jak wynika $\mathrm{z}$ danych przedstawionych przez EMSA jest wynikiem świadomego łamania przepisów. Na drugim miejscu należy wymienić zawinione lub niezawinione zanieczyszczenie wód wynikające ze wypadków. EMSA podaje dane z ostatnich lat w tym zakresie.

19 Por. M. Koziński, Morskie prawo publiczne, Gdynia 2010, s. 111, poza tym zob.: Nestorowicz M.A., Odpowiedzialność cywilna za zanieczyszczenie morza ze statków, Toruń 2002; J. Łopuski, Odpowiedzialność za szkodę w żegludze morskiej, Gdańsk 1969; Z. Brodecki, Obowiazek naprawienia szkód o rozmiarach katastrofalnych, Gdańsk 1978; J. Łopuski, Walka o czyste morze, Gdynia 1972; Z. Brodecki, Ecological Damages in International Law, Warszawa 1990; J. Łopuski, Problemy odpowiedzialności cywilnej za zanieczyszczenia olejami, „Technika i Gospodarka Morska” 1969, nr 6. 
nującego zanieczyszczenia za pomocą systemu monitorowania satelitarnego. Inne źródło zanieczyszczeń to nielegalne zrzucanie odpadów do morza lub wyrzut wód balastowych ze statku. Takie procedery mają duże znaczenia dla poziomu zanieczyszczenia wód w przypadkach mórz zamkniętych, takich jak Morze Bałtyckie, Morze Śródziemne, Morze Czarne, gdzie wymiana wód z pozostałymi obszarami wód jest znacznie ograniczona przez cieśniny. Trzecie źródło zanieczyszczeń to emisja spalin silnikowych pochodzących ze statków $^{20}$. Dotyczy to głównie zasad ograniczenia emisji tlenków siarki azotu z silników oraz emisji samego $\mathrm{CO}_{2}$ i tlenków azotu $^{21}$. Inne problemy wymieniane przez ekspertów z EMSA to używanie farb pokrywających kadłuby statków (systemy poszyć przeciwporostowych), recykling starych statków, zarządzanie wodami balastowymi. Znacznie podkreślany jest problem recyklingu starych jednostek i powstawanie tzw. plaż złomowych na wybrzeżach Azji Południowej, na które trafia znaczna część kadłubów przestarzałych statków z całego świata wycofanych $\mathrm{z}$ eksploatacji ${ }^{22}$.

\section{Zanieczyszczenie środowiska morskiego w prawie międzynarodowym}

Kluczowe znaczenie dla rozważanych tutaj problemów ma rozumienie w ujęciu języka prawnego i prawniczego słowa

20 J. Cydejko, J. Puchalski, G. Rutkowski, Statki i technologie off-shore $w$ zarysie, Gdynia 2011, s. 56.

21 Szerzej na ten temat w dalszej części pracy,. Zob. także: D. Pyć, Uwagi de lege ferenda o statusie Morza Battyckiego jako obszaru kontroli emisji tlenków azotu ze statków morskich, „Prawo Morskie” 2012, t. XXVIII, s. 235 i n.

22 Por. J. Łopuski, Odpowiedzialność za szkodę w żegludze morskiej, Gdańsk 1969, s. 78. 
zanieczyszczenie środowiska morskiego ${ }^{23}$. Mając na względzie dyrektywy wykładni językowej należałoby poszukać po pierwsze definicji legalnej tego terminu. W Konwencji Narodów Zjednoczonych o prawie morza (art. 1 pkt 4) określono zanieczyszczenie środowiska morskiego jako „takie bezpośrednie lub pośrednie wprowadzanie przez człowieka substancji lub energii do środowiska morskiego, łącznie z estuariami, które powoduje lub może powodować takie szkodliwe następstwa, jak: szkody wyrządzone żywym zasobom i życiu w morzu, niebezpieczeństwa dla zdrowia człowieka, przeszkody w działalności na morzu. Inne z kolei jest znaczenie przypisywane pojęciu samego zanieczyszczenia $\mathrm{w}$ ujęciu per se"24.

Pojęcie zanieczyszczenia jako substancji szkodliwej zostało podaje w postaci definicji legalnej na potrzeby konwencji MARPOL. W tejże konwencji „substancja szkodliwa” oznacza jakąkolwiek substancję, która, jeżeli zostanie wprowadzona do morza, może spowodować powstanie niebezpieczeństwa dla zdrowia ludzkiego albo zagrożenie dla żywych zasobów i życia w morzu, pogarszać walory rekreacyjne lub też utrudniać inne zgodne z prawem użytkowanie morza, oraz jakąkolwiek substancję podlegającą kontroli

23 Por. M. Koziński, Morskie prawo publiczne, Gdynia 2010; M.A. Nestorowicz, Odpowiedzialność cywilna za zanieczyszczenie morza ze statków, Toruń 2002; W tym zakresie por. także: Z. Brodecki, Obowiazek naprawienia szkód o rozmiarach katastrofalnych, Gdańsk 1978; J. Łopuski, Walka o czyste morze, Gdynia 1972; Z. Brodecki, Ecological Damages in International Law, Warszawa 1990; J. Łopuski, Problemy odpowiedzialności cywilnej za zanieczyszczenia olejami, „Technika i Gospodarka Morska" 1969; Z. Brodecki, Odpowiedzialność za zanieczyszczenie morza przez statki, Gdańsk 1992.

24 Por. R. Paczulski, Gospodarowanie zasobami wód śródladowych $i$ środowiska morskiego, [w:] idem, Prawo ochrony środowiska, Zarys wykładu, Bydgoszcz 2008, s. 32, jak również przywołana tam literatura. 
na podstawie niniejszej konwencji. Z kolei za „zrzut” w odniesieniu do substancji szkodliwych lub wycieków zawierających takie substancje oznacza się każde usunięcie takich substancji ze statku i obejmuje każde ich przedostanie się do morza, pozbycie, rozlewanie, cieknięcie, pompowanie, wydzielanie lub opróżnianie. Jednocześnie konwencja wprowadza pewne wyłączenia, nakazując niestosowania pojęcia „zrzut” do: zatapiania w rozumieniu Konwencji o zapobieganiu zanieczyszczaniu mórz przez zatapianie odpadów i innych substancji, sporządzonej w Londynie dnia 13 listopada 1972 r. lub usuwania szkodliwych substancji powstałych bezpośrednio w wyniku badań, eksploatacji i przetwarzania na morzu zasobów mineralnych dna morskiego, lub usuwania szkodliwych substancji w celach prawnie uznanych badań naukowych, odnośnie do likwidacji zanieczyszczenia lub jego kontroli ${ }^{25}$.

Norm prawa międzynarodowego w zakresie ochrony środowiska wód morskich można podzielić ze względu na zakres obowiązywania jak słusznie precyzuje Kenig-Witkowska na normy o charakterze powszechnym, regionalnym, partykularnym, w umowach dwustronnych i wielostronnych. Mogą one posiadać charakter norm ważących i niewiążących.

Do grupy norm o charakterze powszechnym niewątpliwie należy zaliczyć na pierwszym miejscu Konwencję Narodów Zjednoczonych z 1982 r. o prawie morza (weszła w życie w 1994 r., zwaną jako Konwencja UNCLOS), Konwencję z 1972 r. o zapobieganiu zanieczyszczaniu mórz przez zatapianie odpadów i innych substancji (zwana także konwencją londyńską) oraz Konwencję z 1973 r. o zapobieganiu zanie-

25 Por. M. Górski, A. Barczak, D. Jakubowska, A. Jaworowicz-Rudolf, A. Kaźmierska-Patryczna, J. Kierzkowska, P. Korzeniowski, J. Miłkowska (red.), op.cit. 
czyszczenia morza przez statki (zwana powszechnie i popularnie jako konwencja MARPOL). Są to normy o charakterze powszechnym, które niewątpliwie stają na czele w hierarchii źródeł prawa w dziedzinie ochrony środowiska mórz.

Normy prawa międzynarodowego w zakresie ochrony środowiska wód morskich można podzielić ze względu na zakres obowiązywania, jak słusznie precyzuje Kenig-Witkowska, na normy o charakterze powszechnym, regionalnym, partykularnym, w umowach dwustronnych i wielostronnych. Mogą one posiadać charakter norm ważących i niewiążących ${ }^{26}$.

\section{Konwencje prawa międzynarodowego}

W obecnym porządku prawnym na poziomie źródeł prawa międzynarodowego mamy wiele konwencji. Na potrzeby tego opracowania można je przedstawić w ujęciu chronologicznym. Konwencja londyńska o zapobieganiu zanieczyszczaniu morza olejami z 1954 r. ze zmianami na konferencji w Londynie w 1962 r. - wprowadziła ustanowienie stref zakazu (od 20-30 mln, poprzez 50 do 100-milowych, całkowity na morzach śródlądowych) usuwania olejów i mieszanki oleistej ze statków. W 1969 r. IMCO przyjęła wiele radykalnych zmian w tej konwencji - generalne ograniczenia dot. usuwania olejów. Inne konwencje to: Konwencja o zapobieganiu zanieczyszczaniu mórz przez zatapianie odpadów i innych substancji z 1972 r. Konwencja o zapobieganiu zanieczyszczaniu mórz przez statki z 1973 r., która wprowadziła konieczność zmian w budowie statków (głów-

26 Por. M.M. Kenig-Witkowska, Ochrona środowiska morskiego, [w:] M.M. Kenig-Witkowska. Międzynarodowe prawo środowiska, Wybrane zagadnienia systemowe, Warszawa 2011, s. 187-203. 
nie zbiornikowców) i w urządzeniach portów (instalacje do odbioru zanieczyszczeń). W momencie wejścia w życie konwencji, w szczególności w odniesieniu do tej drugiej, szybko okazało się, że rozwiązania prawne w niej zawarte są niewystarczające. Okazało się, że brak jest rozwiązania wszystkich problemów, w szczególności brak gwarancji pełnego odszkodowania ofiar zanieczyszczenia, szczególnie w przypadku katastrofalnych skutków ${ }^{27}$. Z tego też powodu wprowadzono w życie kolejną Międzynarodową konwencję o utworzeniu Międzynarodowego Funduszu Odszkodowań za szkody spowodowane zanieczyszczeniem olejami z 1971 r. Jednocześnie opracowano regulacje dotyczące zapobiegania zderzeniom ${ }^{28}$. W tym miejscu należy wspomnieć zunifikowane reguły dotyczące żeglugi zawarte w Konwencji w sprawie międzynarodowych przepisów o zapobieganiu zderzeniom na morzu sporządzonej w Londynie w 1972 r. W związku z koncentracją żeglugi na pewnych obszarach IMO opracowała ponadto systemy rozgraniczenia ruchu dla około stu obszarów ${ }^{29}$. W dalszej części zajęto się sprawami odpowiedzialności za zanieczyszczenia wód morskich. Kwestii odpowiedzialności cywilnej dotyczą konwencje brukselskie z lat 1910 i 1952, w których ujednolicono zasady tej odpowiedzialności ${ }^{30}$. Z kolei od strony odpowiedzialności karnej należy odwołać się do konwencji brukselskiej z 1952 r. o ujednoliceniu niektórych zasad, odnoszących się

27 Por. D. Pyć, 100 lat od katastrofy Titanica - rozwój prawa bezpieczeństwa morskiego, „Prawo Morskie” 2012, t. XXVIII, s. 34-49.

28 Por. Z. Brodecki, Obowiązek naprawienia szkód..., op.cit., s. 44.

29 Por. R. Rakowiec, Odpowiedzialność karna za zanieczyszczanie środowiska $w$ świetle art. 182 k.k., Poznań 2004, s. 34.

30 Por. Z. Brodecki, Odpowiedzialność za zanieczyszczenie morza przez statki, Gdańsk 1992, s. 66. 
do kompetencji karnej w sprawach wynikłych ze zderzenia statków i innych wypadków w żegludze. Konwencja o morzu pełnym wprowadza odpowiedzialność egzekwowaną przed organami sądowymi/administracyjnymi państwa bandery lub państw, którego obywatelem jest dana osoba ${ }^{31}$.

Podsumowując można stwierdzić, że zapobieganie zanieczyszczaniu morza przez statki w dużym stopniu regulowane jest przez akty prawa międzynarodowego. Należą do nich:

1. Międzynarodowa konwencja o zapobieganiu zanieczyszczaniu morza przez statki sporządzona w Londynie dnia 2 listopada 1973 r., zmieniona Protokołem uzupełniającym sporządzonym w Londynie dnia 17 lutego $1978 \mathrm{r}^{32}$ oraz Protokołem uzupełniającym sporządzonym w Londynie dnia 26 września 1997 r. ${ }^{33}$ - tzw. Konwencja MARPOL;

2. Konwencja o ochronie środowiska morskiego obszaru Morza Bałtyckiego sporządzona w Helsinkach dnia 9 kwietnia 1992 r. ${ }^{34}$ - tzw. konwencja helsińska 1992;

3. Konwencja o zapobieganiu zanieczyszczaniu mórz przez zatapianie odpadów i innych substancji, sporządzonej w Moskwie, Waszyngtonie, Londynie i Meksyku dnia 29 grudnia 1972 r. ${ }^{35}$ - tzw. Konwencja o zatapianiu;

4. Międzynarodowa konwencji o bezpieczeństwie życia na morzu, sporządzona w Londynie dnia 1 listopada

31 Por. J. Simonides, Konwencja Narodów Zjednoczonych o prawie morza - w 30 lat od jej przyjęcia, „Prawo Morskie” 2012, t. XXVIII, s. 66.

Dz.U. 1987, nr 17, poz. 101.

Dz.U. 2005, nr 202, poz. 1679.

Dz.U. 2000, nr 28, poz. 346.

Dz.U. 1984, nr 11, poz. 46. 
1974 r. ${ }^{36}$ wraz z Protokołem dotyczącym Międzynarodowej konwencji o bezpieczeństwie życia na morzu, 1974, sporządzonym w Londynie dnia 17 lutego 1978 r. ${ }^{37}$, zwana Konwencją SOLAS;

5. Międzynarodowa konwencji o liniach ładunkowych, sporządzona w Londynie dnia 5 kwietnia $1966 \mathrm{r}^{38}$, zwana Konwencją o liniach ładunkowych;

6. Konwencja w sprawie międzynarodowych przepisów o zapobieganiu zderzeniom na morzu, sporządzona w Londynie dnia 20 października 1972 r. $^{39}$, zwana Konwencją o zapobieganiu zderzeniom.

\section{Konwencje międzynarodowe w zakresie recyklingu statków i odzysku odpadów złomowych}

W dniu 15.05.2009 r. w Hongkongu, po pięciu latach prac przygotowawczych, przyjęta została w Hongkongu Międzynarodowa konwencja o bezpiecznym i przyjaznym dla środowiska recyklingu statków (Hong Kong International Convention for Save and Environmentally Sound Recycling of Ships - SRC 2009). Tekst konwencji obejmuje 21 artykułów, a nadto aneks - „Przepisy o bezpiecznym i przyjaznym dla środowiska recyklingu statków", zawierający 25 prawideł i 7 załączników: 1 - Kontrola niebezpiecznych materiałów; 2 - Lista minimalna inwentaryzacji materiałów niebezpiecznych; 3 - Wzór Międzynarodowego Certyfikatu Inwentaryzacji Niebezpiecznych Materiałów; 4 - Wzór Międzyna-

36

Dz.U. 1984, nr 61, poz. 318 i 319.

Dz.U. 1984, nr 61, poz. 320 i 321 oraz 1986, nr 35, poz. 177.

Dz.U. 1969, nr 33, poz. 282.

Dz.U. 1977, nr 15, poz. 61 i 62 oraz 1984, nr 23, poz. 106. 
rodowego Certyfikatu Gotowości do Recyklingu; 5 - Wzór Autoryzacji Przedsiębiorstwa Recyklingu Statków; 6 - Wzór Zawiadomienia o Rozpoczęciu Recyklingu Statku; 7 - Wzór Oświadczenia o Zakończeniu Recyklingu Statku.

Konwencja ma mieć zastosowanie do wszystkich statków nowych i - o ile to jest możliwe - do statków istniejących o tonażu brutto powyżej 500. Pojęcie statku rozumiane jest szeroko i oznacza każde urządzenie operujące lub przeznaczone do operowania w środowisku morskim, w tym podwodne jednostki pływające, pływające platformy, samopodnoszące się platformy, pływające jednostki składowe (FSUs), pływające jednostki składowo-produkcyjne, w tym statki pozbawione wyposażenia lub holowane.

Konwencja ma zastosowanie do statków podnoszących banderę państwa, będącego stroną konwencji, a także do przedsiębiorstw recyklingowych działających pod jurysdykcją takiego państwa.

Konwencja nie ma zastosowania do okrętów wojennych, pomocniczych jednostek marynarki wojennej oraz statków będących własnością państwa lub przez państwo eksploatowanych w państwowej, niekomercyjnej żegludze. Ponadto nie ma ona zastosowania do statków o tonażu brutto poniżej 500, które pływają wyłącznie po wodach podlegających jurysdykcji państwa, którego banderę mają prawo podnosić.

Każdy statek podlegający przepisom Konwencji SRC, w każdym porcie lub terminalu, należącym do innego państwa-strony konwencji niż jego państwo bandery, może być poddany inspekcji w zakresie wymagań konwencji przez należycie upoważnionych funkcjonariuszy tego państwa. W szczególności kontroli podlegają dokumenty wymagane przez konwencję, to znaczy Międzynarodowy Certyfikat Inwentaryzacji Materiałów Niebezpiecznych (International 
Certificate on Inventory of Hazardous Materials) i Międzynarodowy Certyfikat Gotowości do Recyklingu (International Ready for Recycling Certificate).

W przypadku, gdy statek nie posiada wspomnianych ważnych certyfikatów lub istnieją inne podstawy do przypuszczenia, że stan statku lub jego wyposażenia nie odpowiada danym zawartym w certyfikacie lub (zawartym w konwencji) wykazie materiałów niebezpiecznych bądź nie ma procedury wdrażania na pokładzie systemu inwentaryzacji materiałów niebezpiecznych, możliwe jest dokonanie szczegółowej inspekcji statku zgodnie z wytycznymi IMO.

\section{Podsumowanie i wnioski}

W niniejszej pracy przedstawiono podstawowe metody zapobiegania zanieczyszczeniom wynikające z następujących konwencji morskich: Konwencji Narodów Zjednoczonych o prawie morza, Międzynarodowej konwencji o zapobieganiu zanieczyszczania morza przez statki (MARPOL), Konwencji o zapobieganiu zanieczyszczaniu mórz przez zatapianie odpadów i innych substancji, Międzynarodowej konwencji o odpowiedzialności cywilnej za szkody spowodowane zanieczyszczeniem olejami bunkrowymi, Międzynarodowej konwencji dotyczącej interwencji na morzu pełnym $w$ razie zanieczyszczania olejami.

Pomimo pokaźnej liczby międzynarodowych konwencji w państwach Azji Południowej nadal nie są przestrzegane przepisy w zakresie gospodarki odpadowej w środowisku morskim. Powoduje to znaczny stopień zanieczyszczenia zarówno samych przybrzeżnych wód morskich, jak i zanieczyszczenie odpadami terenów przybrzeżnych. 


\section{Bibliografia}

Brodecki Z., Ecological Damages in International Law, Warszawa 1990.

Brodecki Z., Obowiązek naprawienia szkód o rozmiarach katastrofalnych, Gdańsk 1978.

Depowski S., Kotliński R., Rühle E., Szamałek K. (red.), Surowce mineralne mórz i oceanów, Warszawa1998.

Drogosiewicz M., Nowakowski J., Eksploatacja statku handlowego, Gdynia 2000.

Górski M., Barczak A., Jakubowska D., Jaworowicz-Rudolf A., Kaźmierska-Patryczna A., Kierzkowska J., Korzeniowski P., Miłkowska J. (red.), Prawo ochrony środowiska, Warszawa 2009.

Kenig-Witkowska M.M., Ochrona środowiska morskiego, [w:] M.M. Kenig-Witkowska, Międzynarodowe prawo środowiska. Wybrane zagadnienia systemowe, Warszawa 2011.

Koziński M., Morskie prawo publiczne, Gdynia 2010.

Kubicki J., Ekonomika i organizacja transportu morskiego, cz. I: Organizacja transportu morskiego, Gdynia 1992.

Kujawa J., Organizacja i technika transportu morskiego, Gdańsk 2005.

Kuźma L. (red.), Ekonomika portów morskich i polityka portowa, Gdańsk 2003.

Łopuski J., Odpowiedzialność za szkodę w żegludze morskiej, Gdańsk 1969.

Łopuski J., Problemy odpowiedzialności cywilnej za zanieczyszczenia olejami, „Technika i Gospodarka Morska” 1969.

Łopuski J., Walka o czyste morze, Gdynia 1972.

Nestorowicz M.A., Odpowiedzialność cywilna za zanieczyszczenie morza ze statków, Toruń 2002. 
Paczulski R., Gospodarowanie zasobami wód śródlądowych i środowiska morskiego, [w:] R. Paczulski, Prawo ochrony środowiska. Zarys wyktadu, Bydgoszcz 2008.

Plewiński L., Wypadki na morzu, Szczecin 2000.

Pyć D., 100 lat od katastrofy Titanica - rozwój prawa bezpieczeństwa morskiego, „Prawo Morskie” 2012, t. XXVIII. Pyć D., Prawo Oceanu Światowego. Res usus publicum, Gdańsk 2011.

Pyć D., Uwagi de lege ferenda o statusie Morza Battyckiego jako obszaru kontroli emisji tlenków azotu ze statków morskich, „Prawo Morskie” 2012, t. XXVIII.

Radecki W. Prawo ochrony środowiska. Wybrane problemy, Warszawa 2010.

Rakowiec R., Odpowiedzialność karna za zanieczyszczanie środowiska w świetle art. 182 k.k., Poznań 2004.

Simonides J., Konwencja Narodów Zjednoczonych o prawie morza - w 30 lat od jej przyjęcia, „Prawo Morskie” 2012, t. XXVIII.

Sobol E. (red.), Nowy stownik języka polskiego, Warszawa 2002.

Zarzycki R., Aerosfera - źródta i rodzaje zanieczyszczeń, sposoby jej ochrony, [w:] Ekologia. Jej związki z różnymi dziedzinami wiedzy, red. A. Kurnatowska, Warszawa-Łódź 1997.

\begin{abstract}
Abstrakt
Problematyka odpadów wydaje się być jedną z kluczowych kwestii we współczesnym prawie ochrony środowiska. Praca dotyczy jednej $\mathrm{z}$ wielu sfer ochrony środowiska przed odpadami, jakim jest recycling statków. Przepisy w tym zakresie znajdziemy na gruncie prawa międzynarodowego, unijnego (jeśli chodzi o państwa Unii Europejskiej), jak i w porządkach krajowych. Dotyczą również krajów azjatyckich,
\end{abstract}


jednak w porównaniu z Europą regulacje prawa międzynarodowego są słabiej egzekwowane. To powoduje, że znaczna część starych jednostek jest kierowana do rozbiórki do państw Azji Południowej ze względu na obejście wymogów środowiska. Praca przedstawia wybrane regulacje ochrony środowiska wód morskich przed zanieczyszczeniami odpadami pochodzącymi ze statków i w procesie ich recyclingu oraz rozbiórki. Konkluzją pracy jest brak wystarczającej skuteczności prawnych instrumentów reglamentacyjnych w dziedzinie prewencji zanieczyszczeniu odpadami ze statków w państwach Azji Południowej, co jest już długo trwającym procederem zauważanym przez społeczność międzynarodową.

Słowa kluczowe: recycling statków, stocznie złomowe w Azji, ochrona wód morskich, gospodarka odpadami, ochrona środowiska morskiego

\begin{abstract}
The issue of waste seems to be one of the key issues in contemporary environmental law. The work concerns one of the many spheres of environmental protection against waste, which is ship recycling. The provisions in this area can be found on the basis of international law, EU law (when it comes to European Union countries) as well as national systems. They also apply to Asian countries, but in comparison with Europe, international law regulations are less enforced. As a result, a significant part of old units is sent for demolition to the countries of South Asia due to the circumvention of environmental requirements. The paper presents selected regulations for the protection of marine waters environment against pollution by ship waste and in the process of their recycling and demolition. The conclusion of the work is the lack of sufficient effectiveness of legal regulatory instruments in the field of prevention of pollution by ship waste in the countries of South Asia, which is a long practice noticed by the international community.
\end{abstract}

Keywords: ship recycling, Asian scrap yards, protection of sea waters, waste management, protection of the marine environment 


\section{Grażyna Strnad}

Uniwersytet im. Adama Mickiewicza w Poznaniu

ORCID ID: https://orcid.org/0000-0001-5774-4543

\section{Fenomen studiów koreanistycznych w Polsce - geneza, ewolucja, znaczenie}

Od wielu lat zainteresowanie koreańską kulturą, językiem i historią nieustannie rośnie, szczególnie wśród młodego pokolenia Polek i Polaków. Fascynacja i podziw „Krajem Cichego Poranka” ma swój początek między innymi w przekazach, które dotarły do Polski dzięki weneckiemu kupcowi Marcowi Polo. Informacje o dawnej Korei mogliśmy uzyskać także dzięki pierwszym Polakom, którzy przybyli na Półwysep Koreański pod koniec XIX w. Byli to naukowcy-podróżnicy: Jan Kalinowski ${ }^{1}$ i Władysław Kotwicz ${ }^{2}$. Kalinowski przebywał w Korei w latach 1885-1886. Po powrocie z tej egzotycznej podróży badacz opublikował w polskim czasopiśmie „Wszechświat” artykuł pt. List z Korei. Scharakteryzował w nim życie i obyczaje ówczesnych Koreańczyków. Z kolei dzieło Kotwicza Opisanije Korei, opublikowane w 1900 r. przez Ministerstwo Finansów Rosji, uznawane było w tamtym okresie za najlepsze kompendium wiedzy o Ko-

1 Jan Kalinowski był zoologiem. Podczas swojego pobytu w Korei poszukiwał gatunków fauny koreańskiej. Obecnie znajdują się one m.in. w Instytucie Zoologii Polskiej Akademii Nauk w Warszawie.

2 Wacław Kotwicz był jednym z najwybitniejszych orientalistów polskich, profesorem Uniwersytetu Wileńskiego, pierwszym przewodniczącym Polskiego Towarzystwa Orientalistycznego. 
rei $^{3}$. Do grona polskich podróżników, naukowców, którzy odwiedzili Półwysep Koreański na początku XX w. należeli także: profesor Ferdynand Antoni Ossendowski, geograf Kazimierz Grochowski, geograf Aleksander Ludwik Janowski, pisarz Remigiusz Kwiatkowski, profesor Uniwersytetu Wileńskiego Stefan Bryła.

Najbardziej znanym Polakiem, który przebywał w Korei był Wacław Sieroszewski ${ }^{4}$. Na początku XX w., w 1905 r. opublikował książkę Korea. Klucz do Dalekiego Wschodu. Sieroszewski tak opisywał Koreę:

Korea cudny kraj! Żyzność ziemi niesłychana, urodzaje egipskie! Potoki taniego, korejskiego ryżu zalewają nawet ryżową Japonię. Tam rosną nieprzejrzane lasy drogocennych drzew; cedry, cyprysy, jesiony, korkowe dęby... Nieprzebrane bogactwa mineralne czekają niecierpliwie dzielnej ręki Europejczyka... Złota, żelaza i miedzi w bród!... A jest i węgiel i marmur!... Ptactwa roje: bażanty, kaczki, gęsi i łabędzie latają nad jasnemi polami; stada jeleni, antylop, kóz i dzików brodzą w górach. Jest to raj myśliwców! Ale trzeba być ostrożnym, gdyż są tam i tygrysy. Gaje mirtowe rzucają swe cienie na ukwiecone łąki, a wszystko kąpie się w słonecznem, łagodnem powietrzu i ciepłych błękitnych morzach... Potulna ludność chętnie płaci podatki, czci władzę i pracuje napół darmo - z przyzwyczajenia i dla przyjemności ${ }^{5}$.

3 M. Burdelski, Stosunki Polski z obydwoma państwami koreańskimi - wczoraj - dziś - jutro, [w:] Korea w oczach Polaków. Państwo - społeczeństwo - kultura, red. J. Włodarski, K. Zeidler, M. Burdelski, Gdańsk 2012, s. 274.

4 Wacław Sieroszewski 1858-194 (pseudonim: Wacław Sirko) - pisarz, działacz niepodległościowy, podróżnik, etnograf, sybirak, żołnierz legionów Józefa Piłsudskiego, poseł i senator II RP, minister informacji i propagandy w Tymczasowym Rządzie Ludowym Republiki Polskiej w Lublinie, w latach 1933-1938 był prezesem Polskiej Akademii Literatury.

5 W. Sieroszewski, Korea. Klucz do Dalekiego Wschodu, Warszawa 1905 , s. 5. 
Półwysep Koreański ponad tysiąc lat należał do jednego państwa. W 1945 r., po okresie japońskiej okupacji, Korea, jedno z najstarszych państw świata, została podzielona na dwie strefy okupacyjne: amerykańską na południu i sowiecką na północy. Trzy lata później, w 1948 r., wbrew woli samych Koreańczyków utworzono dwa państwa koreańskie: Republikę Korei (15 sierpnia) i Koreańską Republikę Ludowo-Demokratyczną (9 września).

W okresie zimnej wojny porządek światowy opierał się na systemie dwubiegunowym, w którym dominującą pozycję zajmowały dwa mocarstwa: Stany Zjednoczone i Związek Sowiecki. Po drugiej wojnie światowej Polska nawiązała kontakty jedynie z państwem Kim Ir Sena. Korea Północna i Polska należały bowiem do obozu państw bloku socjalistycznego. Na początku października 1948 r. Korea Północna zaproponowała nawiązanie stosunków dyplomatycznych z Polską. W odpowiedzi polski rząd uznał KRLD i nawiązał stosunki dyplomatyczne 16 października 1948 r. Polska jest trzecim państwem, które uznało istnienie Korei Północnej. Stosunki między państwami były szczególnie przyjazne w latach 50. i 60. XX w. W panującej wówczas zimnowojennej rywalizacji pomiędzy blokiem wschodnim a państwami zachodnimi, której apogeum stanowiła wojna koreańska ${ }^{6}$,

6 Wojna koreańska rozpoczęła się 25 czerwca 1950 r. o godzinie 4:00 rano, kiedy wojska północnokoreańskie przekroczyły 38. równoleżnik. Negocjacje w sprawie zakończenia konfliktu rozpoczęły się 10 lipca 1951 r. w Kaesong (terytorium Korei Północnej). Od 25 października 1951 r. negocjacje prowadzone były w miejscowości Panmundżom. Pertraktacje trwały do połowy $1953 \mathrm{r}$. W ich wyniku podpisano 27 lipca 1953 r. układ rozejmowy. Na jego mocy powołał do życia Komisję Nadzorczą Państw Neutralnych, powołano w skład której weszli na zaproszenie Koreańskiej Armii Ludowej i Chińskich Ochotników Ludowych (Polska i Czechosłowacja) oraz z inicjatywy ONZ (Szwajcaria i Szwecja). Do zadań komisji należało nadzorowanie postanowień przyjętych przez rozejm. W wyniku rozejmu ustanowiono 4-kilometrową linię demarka- 
rząd PRL poparł Koreę Północną przedstawiającą siebie jako ofiarę amerykańskiego imperializmu. Wyrazem solidarności Polaków z doświadczającymi wojny Koreańczykami z Północy były publikowane w prasie informacje o „wiecznej braterskie pomocy", organizowane zbiórki pieniędzy i darów oraz masowe wiece poparcia pod hasłem "ręce precz od Korei”. Polska wraz z innymi państwami socjalistycznymi angażowała się także w udzielanie Korei Północnej pomocy gospodarczej i finansowej. Szczególnym wyrazem współpracy było udzielenie pomocy humanitarnej przez polski rząd w okresie wojny koreańskiej oraz po jej zakończeniu poprzez przyjęcie dzieci, sierot północnokoreańskich, które w wyniku wojny straciły swoje rodziny.

W 1956 r. Kim Ir Sen złożył oficjalną wizytę w Polsce, podczas której odwiedził Dom Dziecka w Świdrze ${ }^{7}$. Była to pierwsza wizyta przywódcy Korei Północnej w Polsce. Do drugiej doszło trzydzieści lat później w 1986 r. ${ }^{8}$

Na przełomie lat 80. i 90. XX w. załamał się porządek jałtański, system dwubiegunowy, rozpadł się blok socjalistyczny i zbliżał się nieuchronny upadek Związku Sowieckiego, a wraz z nim kończył się okres zimnowojennej

cyjną, strefa ta stała się granicą pomiędzy dwoma państwami koreańskimi. W wyniku wojny koreańskiej zostało rozdzielonych miliony rodzin, a wiele dzieci nigdy nie odnalazło swoich rodziców.

7 Na terenie Polski dzieci znajdowały się w pięciu ośrodkach wychowawczych. Największymi z nich były ośrodki w Płakowicach i Otwocku. Po raz pierwszy dzieci przyjechały do Polski w 1951 r. Ponad tysiąc dzieci północnokoreańskich, które przyjechały do Polski w 1953 r. zostało umieszczonych w Płakowicach koło Lwówka Śląskiego i w Szklarskiej Porębie. Wszystkie ośrodki edukacyjno-wychowawcze dla północnokoreańskich sierot w Polsce były pod kontrolą i wsparciem finansowym Ministerstwa Spraw Zagranicznych. Obecność dzieci z Korei Północnej była utrzymywana w wielkiej tajemnicy. Dzieci były w wieku od 5 do 14 lat.

8 G. Strnad, Dzieci wojny koreańskiej, [w:] Dzieci i doświadczenia wojny. Wiek XX i XXI, red. M. Grzywacz, M. Okupnik, Poznań 2020, s. 68. 
konfrontacji. Korea Południowa należąca do obozu państw kapitalistycznych stała się w 1988 r. gospodarzem Letnich Igrzysk Olimpijskich w Seulu. Korea Południowa odniosła sukces, prowadząc skuteczną dyplomację, przekonała zarówno przedstawicieli państw Wschodu, jak i Zachodu do uczestnictwa w organizowanych międzynarodowych zawodach sportowych, dążąc jednocześnie do nawiązania z nimi stosunków gospodarczych i politycznych?

Stosunki dyplomatyczne między Polską a Republiką Korei zostały nawiązane 1 listopada $1989 \mathrm{r}$. Zapoczątkowały one budowanie kontaktów wzajemnych na wielu polach w ramach partnerstwa strategicznego. Umożliwiły rozwijanie owocnej współpracy gospodarczej, naukowej i kulturalnej. Ustanowiły współpracę akademicką, przyznawanie stypendiów naukowo-badawczych, promowanie kultury koreańskiej w Polsce i kultury polskiej w Korei Południowej.

Korea Południowa należy do państw, które przez wiele lat uznawane były za jeden z najbiedniejszych rolniczych rejonów świata. Od 1962 r. „Kraj Porannej Ciszy” stał się miejscem szybkiej industrializacji, osiągając w końcu lat 80 . status państwa nowo uprzemysłowionego. Spektakularny sukces gospodarczy nazywany „cudem gospodarczym nad rzeką" Han stał się kluczem do międzynarodowego awansu Korei Południowej. W ciągu zaledwie jednego pokolenia jeden z najbiedniejszych państw awansował do grona najbardziej rozwiniętych i najbardziej zaawansowanych technologicznie gospodarek świata. Korea Południowa stała się dla wielu państw wzorem przedsiębiorczości, wzorem państwa nowoczesnego, „azjatyckim tygrysem” - modelem sukcesu ekonomicznego, przykładem demokratycznej tranzycji,

9 Eadem, Korea. Polityka Potudnia wobec Pótnocy w latach 1948-2008. Zmiana i kontynuacja, Poznań 2014, s. 226-241. 
światowym liderem innowacyjności. Korea Południowa to dzisiaj czwarta największa gospodarka Azji i piąte na świecie państwo pod względem łatwości prowadzenia biznesu w rankingu Banku Światowego „Doing Business 2020”.

Globalnym fenomenem jest południowokoreański zespół BTS $^{10}$, który nieustannie zdobywa szczyty list przebojów w wielu krajach. Południowokoreański zespół zapisał się bowiem w historii jako pierwsza niezachodnia grupa muzyczna, która trafiła na pierwsze miejsce zestawienia Międzynarodowej Federacji Przemysłu Fonograficznego (IFPI). Sukces tego boysbandu jest tym większy, że artyści nie śpiewają tylko po angielsku. Muzycy BTS to ambasadorzy kultury i języka koreańskiego na świecie. BTS to światowy fenomen, jego członkowie znajdują się na czele listy najlepiej sprzedających się artystów w 2020 r.

Kultura i media zostały uznane w Korei Południowej za „strategiczną gałąź przemysłu narodowego XXI w." Współdziałanie Ministerstwa Kultury i Turystyki z medialnymi korporacjami stworzyło mechanizm sukcesu „koreańskiej fali”"1. Ekspansja koreańskiej kultury jest ściśle powiązana z globalizacją i rozwojem Internetu. Współcześnie nowe idee rozprze-

10 Zespół BTS, znany również jako Beyond The Scene, powstał w 2013 r. i tworzy go siedmiu artystów. Grupa stała się światowym fenomenem wynosząc K-pop na arenę międzynarodową, a o ich popularności niech świadczą pobite rekordy: są pierwszymi koreańskimi artystami, którzy dotarli ze swoją płytą na pierwsze miejsce na liście albumów Billboard 200, teledysk do utworu „Dynamite” zyskał największą liczbą wyświetleń w ciągu 24 godzin; zaledwie w 3 godziny i 31 minut zyskali milion obserwujących na TikToku, bijąc tym samym rekord Guinnessa.

11 Korean wave to określenie stosowane do opisu rozprzestrzeniania się koreańskiej kultury masowej (popularnej) na świecie. Hallyu w języku koreańskim oznacza dosłownie „koreańską falę”. Najważniejszymi elementami składowymi hallyu są koreańskie produkty medialne: muzyka popularna, nazywana K-popem, seriale, czyli K-dramy oraz koreańskie filmy. 
strzeniają się szybciej niż kiedykolwiek wcześniej. Kultura pop pomogła zbudować atrakcyjny wizerunek południowokoreańskiego państwa łączącego tradycję z nowoczesnością, hallyu otworzyło Koreę Południową na świat ${ }^{12}$.

W lutym 2020 r. Koreańczycy z Południa mogli świętować kolejny spektakularny sukces w ramach tzw. koreańskiej fali. Południowokoreański reżyser Bong Joon-Ho odebrał cztery Oskary za film Parasite, za: najlepszy film nieanglojęzyczny, najlepszy scenariusz oryginalny, najlepszy film i dla najlepszego reżysera, stając się prawdziwą sensacją w Hollywood.

Z kolei Korea Północna ciągle postrzegana jest za jedno z najbardziej tajemniczych miejsc na świecie. Niedostępne totalitarne państwo, w którym władzę nieprzerwanie od $1948 \mathrm{r}$. sprawuje jedyna na świecie komunistyczna dynastia Kimów. Nie bez znaczenia jest także fakt, że Korea Północna jest wielkim wyzwaniem dla bezpieczeństwa międzynarodowego. Rząd Stanów Zjednoczonych ostrzega, że Korea Północna nadal pozyskuje materiały i sprzęt do swojego programu rakiet balistycznych, pomimo oficjalnych zapewnień władz północnokoreańskich o porzuceniu ambicji nuklearnych.

9 października 2006 r. Korea Północna przeprowadziła pierwszą próbę nuklearną ${ }^{13}$. Północnokoreańskie władze podejmowały testy także w kolejnych latach: 25 maja 2009 r., 12 lutego 2013 r., 6 stycznia i 9 września 2016 r., 3 września 2017 r. W tym samym czasie rozwijano także badania nad technologią rakietową. Północnokoreański program ato-

12 Pisząc o kulturze popularnej warto wspomnieć o najbardziej znanej wśród Koreańczyków pieśni Arirang, która w 2012 r. zapisana została na listę światowego dziedzictwa UNESCO.

13 V. Jackson, Does Nuclearization Impact Threat Credibility. Insights from the Korean Peninsula, [w:] S.Ch.Kim, M.D. Cohen, North Korea and nuclear weapons. Entering the new era of deterrence, Washington, DC, 2017, s. 96. 
mowy i rakietowy jest często przyczyną napiętej sytuacji na Półwyspie Koreańskim. Przeprowadzenie testów atomowych i prób międzykontynentalnych pocisków balistycznych coraz częściej wzbudza wśród społeczności międzynarodowej obawy o bezpieczeństwo w regionie, jak i na świecie.

Półwysep Koreański to specyficzne miejsce na mapie politycznej świata. Znajdują się tutaj dwa państwa, w których żyje podzielony naród. Do dnia dzisiejszego nie został rozwiązany tak zwany problem koreański będący pozostałością zimnowojennej rywalizacji mocarstw. Koreańczycy to dumny naród, a Korea to jedno z najstarszych państw świata. Cywilizacja koreańska licząca blisko pięć tysięcy lat historii jest przedmiotem zainteresowania coraz większej i coraz młodszej grupy odbiorców. Wyrazem tego zainteresowania jest rosnąca popularność studiów koreanistycznych w Polsce. Uwagę kandydatów na studia przyciągają przede wszystkim: koreańska muzyka popularna, nazywana K-popem, seriale, czyli K-dramy, koreańskie filmy, koreańska kultura, taekwondo - narodowy sport Korei, odmienna tradycja i obyczaje, piękne hanboki, egzotyczne świątynie i wartości konfucjańskie. To wszystko sprawia, że młodzi ludzie chcą uczyć się języka koreańskiego, którym włada ponad 77 mln ludzi na całym świecie.

Absolwenci studiów koreanistycznych z łatwością znajdują pracę w kraju i za granicą. Po ich ukończeniu mogą liczyć zarówno na pewne zatrudnienie, jak i na atrakcyjne zarobki. Znajomość języka koreańskiego umożliwia pracę w dyplomacji, administracji państwowej, przedsiębiorstwach koreańskich ${ }^{14}$, instytucjach kulturalnych i naukowo-

14 Warto podkreślić, że Wrocław jest jednym z pięciu miejsc na świecie, gdzie południowokoreańska firma LG otworzyła swoje fabryki. W samym tylko Wrocławiu jest około 200 oddziałów koreańskich firm, 
-badawczych, biurach podróży. Przy istniejącej współcześnie skali kontaktów biznesowych, naukowych i kulturalnych zapotrzebowanie na tłumaczy i ekspertów od spraw koreańskich w różnych dziedzinach nauki jest ogromne. Warto pamiętać, że studia koreanistyczne nie są tylko zarezerwowane dla badaczy z dziedziny językoznawstwa czy literaturoznawstwa. Problematyką koreańską zajmują się także historycy, archeolodzy, politolodzy, ekonomiści czy muzykolodzy.

Obecnie studia koreanistyczne prowadzone są w głównych ośrodkach akademickich w Polsce - na Uniwersytecie im. Adama Mickiewicza w Poznaniu (filologia koreańska, studia dzienne i wieczorowe), Uniwersytecie Warszawskim (studia dzienne i wieczorowe), Uniwersytecie Jagiellońskim w Krakowie (studia nad Koreą), Uniwersytecie Wrocławskim. Na każdej uczelni wymagania są podobne, próg punktowy wynosi mniej więcej 85-89 punktów, a na jedno miejsce przypada zazwyczaj 11-25 osób.

O głębszym zainteresowaniu nauką języka koreańskiego w Polsce można mówić dopiero od początku lat 50. „Na Uniwersytecie Warszawskim do 1953 r. nie było lektoratu języka koreańskiego. Wojna koreańska lat 1950-1953 wzbudziła wśród części studentów sinologii zainteresowanie Koreą, jednak jedyną osobą, która wtedy mogła poprowadzić naukę języka koreańskiego dla początkujących był mieszkający w Warszawie stomatolog Ru Tong-chu. Od jesieni 1952 r. zastąpił go oddelegowany z KRL-D lektor Kim Czhun-thek. Wykładał on na Uniwersytecie Warszawskim przez 8 lat, prowadząc zajęcia z języka i literatury koreańskiej dla studentów sinologii"15. Do grona absolwentów sinologii Instytutu

https://www.polsatnews.pl/wiadomosc/2020-09-27/kolejki-na-koreanistyke-inspiracja-dla-kandydatow-k-pop/.

15 Fragmenty artykułu dr H. Ogarek-Czoj z „Przeglądu Orientali- 
Orientalistycznego UW, którzy w czasie studiów uczęszczali na lektorat języka koreańskiego, należała pionierka polskiej koreanistyki dr Halina Ogarek-Choj. Jest ona także absolwentką Uniwersytetu imienia Kim Ir Sena w Pjongjangu, gdzie obroniła w 1962 r. pracę naukową uzyskując stopień kandydata nauk. Od października 1962 r. dr Ogarek-Choj pracowała na Uniwersytecie Warszawskim, ucząc przez wiele lat języka i gramatyki koreańskiej oraz prowadząc wykłady z historii i literatury Korei dla studentów japonistyki. Na Uniwersytecie Warszawskim do roku akademickiego 1960/1961 język koreański był wykładany jako trzeci język orientalny dla studentów sinologii. Z kolei od roku akademickiego 1960/1961 studenci japonistyki mogli dokonywać wyboru drugiego języka orientalnego (chińskiego lub koreańskiego). Zajęcia z języka koreańskiego prowadzili wówczas także lektorzy z Korei Północnej. Dzięki współpracy z północnokoreańskimi lektorami wydano w Polsce dwa skrypty do nauki języka koreańskiego w latach 1977 i 1990. Do końca lat 70. nie było w Polsce żadnego dostępu do materiałów edukacyjnych czy publikacji naukowych pochodzących z Korei Południowej. Dopiero po nawiązaniu współpracy z Towarzystwem Studiów Koreanistycznych w Europie w 1978 r., wykładowcy i studenci Uniwersytetu Warszawskiego otrzymali w formie darów z Korei Południowej różne publikacje związane ze studiami koreanistycznymi. Do końca lat 70. podstawą studiów koreanistycznych były publikacje pochodzące z Korei Północnej. Uzyskane w późniejszym okresie profesjonalne materiały naukowo-dydaktyczne z zakresu koreanistyki pozwoliły na opracowanie programu pięcioletnich studiów koreanistycznych w ramach Zakładu Dalekiego Wschodu Instytutu

stycznego" 1998, nr 3-4, http://www.koreanistyka.orient.uw.edu.pl/dhoc. html [dostęp: 3.05.2021]. 
Orientalistycznego UW. Od roku akademickiego 1983/1984 studenci mogli wybrać język koreański jako pierwszy język orientalny, zaś jako drugi mogli wybrać chiński lub japoński. Takie były początki warszawskiej koreanistyki ${ }^{16}$.

W 2003 r. profesor Jerzy Bańczerowski opublikował artykuł pt. Korea w kręgu zainteresowań Instytutu Językoznawstwa Uniwersytetu im. Adama Mickiewicza w Poznaniu. Przedstawił w nim historię narodzin poznańskiej koreanistyki. Napisał, że „w ostatnich 10 latach nastąpił wprost gwałtowny zwrot ku Korei w skali światowej. Uruchomiono programy badawcze i dydaktyczne w wielu krajach, gdzie dotychczas takowych w ogóle nie było. Najbardziej widoczny wzrost zainteresowania tym krajem obserwuje się w Australii, w Stanach Zjednoczonych, i w wielu krajach afrykańskich i azjatyckich, szczególnie w Chinach, Wietnamie, Mongolii i Tajlandii. Znamienny wzrost w nastawieniu do Korei daje się zauważyć w Japonii - kraju, który przez długie lata Koreę okupował, a gdzie obecnie coraz więcej studentów decyduje się na naukę języka koreańskiego oraz studiuje koreańską kulturę i historię. Szereg uniwersytetów japońskich zatrudnia koreanistów i sinologów w miejsce odchodzących na emeryturę profesorów francuskiego i niemieckiego"17.

W 1988 r. w Instytucie Językoznawstwa UAM rozpoczął się lektorat języka koreańskiego, jego pierwszym wykładowcą był dr Romuald Huszcza z Uniwersytetu Warszawskiego. W zajęciach uczestniczyli głównie studenci poznańskiej japonistyki i sinologii. Drugi okres w nauczaniu języka ko-

16 Dr Joanna Rurarz, Księga jubileuszowa na 75-lecie IO UW, Zakład Japonistyki i Koreanistyki, sekcja koreanistyki, http://www.koreanistyka. orient.uw.edu.pl/historia.html [dostęp: 4.05.2021].

17 J. Bańczerowski, Korea w kręgu zainteresowań Instytutu Językoznawstwa Uniwersytetu im. Adama Mickiewicza w Poznaniu, „Scripta Neophilologica" 2003, t. V, s. 7-8. 
reańskiego związany był bezpośrednio z wizytą profesora Bańczerowskiego w Ambasadzie Republiki Korei, który skutecznie potrafił przekonać południowokoreańskich dyplomatów do podjęcia z UAM naukowej współpracy. Wkrótce język koreański uzyskał w dydaktyce Instytutu Językoznawstwa status języka specjalistycznego w ramach specjalności Etnolingwistyka.

W kwietniu 2002 r. władze Instytutu Językoznawstwa wystąpiły z wnioskiem do Rady Wydziału Neofilologii o powołanie do życia nowej specjalności o nazwie filologia koreańska. Umożliwiło to uruchomienie w 2003 r. pięcioletnich studiów magisterskich o nazwie filologia koreańska. W tym samym czasie powstała Pracownia Języka i Kultury Koreańskiej pod kierownictwem profesora Jerzego Bańczerowskiego. Należy podkreślić, że Uniwersytet im. Adama Mickiewicza w Poznaniu jako jedyny ośrodek akademicki oferuje kierunek filologia koreańska. Od 2007 r. pięcioletnie studia magisterskie na kierunku filologia koreańska rozdzielono na trzyletnie studia licencjackie i dwuletnie studia magisterskie.

W 2018 r. Zakład Filologii Koreańskiej obchodził uroczyście piętnastolecie swojego istnienia. Organizowane przez zakład konferencje koreanistyczne, ogólnopolskie i międzynarodowe oraz przygotowane z wielką pasją dni kultury koreańskiej wpisały się na stałe w działalność naukową i popularyzatorską poznańskich koreanistów. Warto także wspomnieć, że w Instytucie Językoznawstwa od 2015 r. było wydawane czasopismo naukowe „International Journal of Korean Humanities and Social Science" poświęcone problemom szeroko pojętych studiów koreanistycznych.

W 2016 r. Zakład Filologii Koreańskiej przystąpił do programu CEEPUS (Central European Exchange Program for University Studies). Dzięki tej inicjatywie w ramach sieci - 
South and North Korea, Korean and Koreans: Research, Research Based Teaching \& Networking for Synergies in Central and Eastern Europe - koreaniści z różnych ośrodków akademickich na świecie mogą odbywać wykłady gościnne w UAM dla studentów koreanistyki. Wykładowcy i studenci mogą odbywać staże naukowo-badawcze w ośrodkach koreanistycznych w Austrii, Bułgarii, Czechach, Chorwacji, Rumunii, Serbii, Słowacji, Słowenii i na Węgrzech. W ten sposób prężnie działa międzynarodowa współpraca i wymiana akademicka.

Szczególną inicjatywą promującą i rozwijającą studia koreanistyczne są kluby studenckie (koła naukowe) zaangażowane w promocję języka i kultury koreańskiej w Polsce. W Poznaniu na koreanistyce działają: klub studencki Hae-ohwa (Taniec z wachlarzami), Keun-soriro (Tradycyjne bębny koreańskie), Sogo Team (Taniec z bębenkiem sogo) i grupa taneczna K-Pop. Od 2018 r. działa także najmłodsze studenckie koło naukowe koreanistów Hwansae ${ }^{18}$.

Zainteresowanie studiami koreanistycznymi w Poznaniu wzrasta z roku na rok. Filologia koreańska znajduje się już od kilku lat w rankingu dziesięciu najbardziej popularnych kierunków na UAM, podobnie jest także na Uniwersytecie Warszawskim czy Uniwersytecie Jagiellońskim. Jest obecnie swoista moda na Koreę. Z tego powodu na uniwersytetach zarówno w Poznaniu, jak i Warszawie zdecydowano się na uruchomienie wieczorowych studiów koreanistycznych. Utworzono atrakcyjny program nauczania praktycznego języka koreańskiego z podziałem na bloki: konwersacje, słuchanie, czytanie tekstu, pisanie, gramatyka, nauka słownictwa. Waż-

18 P. Kida, Historia filologii koreańskiej Uniwersytetu im. Adama Mickiewicza w Poznaniu w zarysie, [w:] Meandry koreanistyki. Księga jubileuszowa $z$ okazji 15-lecia powstania filologii koreańskiej UAM, red. P. Kidy, G. Strnad, Poznań 2018, s. 11. 
ną częścią koreanistycznej edukacji są także zajęcia z historii języka koreańskiego, historii literatury koreańskiej, historii Korei, kultury koreańskiej, wprowadzenia do sinogramów, teorii i praktyki przekładu. Studenci mogą uczestniczyć także w zajęcia fakultatywnych z dyplomacji i polityki koreańskiej.

Studia nad Koreą prowadzone są także na Uniwersytecie Jagiellońskim w Instytucie Bliskiego i Dalekiego Wschodu na Wydziale Studiów Międzynarodowych i Politycznych. Charakteryzują się interdyscyplinarnym podejściem badawczym, ze szczególnym uwzględnieniem problemów społeczno-kulturowych, badanych w szerokim kontekście historycznym, a także w oparciu o specyficzną sytuację polityczną i gospodarczą regionu Azji Wschodniej. Takie podejście odróżnia interdyscyplinarne studia nad Koreą od tradycyjnych dyscyplin orientalistycznych głównie zorientowanych filologicznie.

Studia nad Koreą oferowane przez UJ to obecnie jedyny program w Polsce prowadzony poza kierunkiem filologicznym. Kursy języka koreańskiego prowadzone były w Krakowie już od roku akademickiego 2000/2001. W 2014 r. został utworzony w ramach studiów azjatyckich - moduł koreański, a w lutym 2017 r. utworzono Zakład Korei. W ramach oferty dydaktycznej studenci IDiBW mogą studiować koreanistykę na studiach pierwszego i drugiego stopnia. Studia nad Koreą to zarówno kulturoznawstwo koreańskie, jak i zdobycie wiedzy o stosunkach politycznych i ekonomicznych oraz praktyczna nauka języka. W imponujących planach studiów studenci mają takie przedmioty, jak: lektorat z języka koreańskiego, język koreański w praktyce, historia Korei, historia polityczno-społeczna Korei, popkultura koreańska, relacje Korea Południowa-Północna, cywilizacja konfucjańska, motywy indyjskie w kulturze koreańskiej, 
Korea Południowa - aspekty współczesnej historii, polityka zagraniczna Korei Południowej i Północnej, filozoficzne aspekty kina dalekowschodniego, feminizm w Korei Południowej, japońska okupacja w Korei, realioznawstwo koreańskie, relacje polsko-koreańskie w XX w. ${ }^{19}$

Zajęcia na kierunku studia nad Koreą dają studentom możliwość uczestnictwa w warsztatach, konferencjach i seminariach naukowych oraz oferują stypendia zagraniczne w Republice Korei czy też m.in. w ramach programu Erasmus. Ponadto studenci studiów nad Koreą w Instytucie Bliskiego i Dalekiego Wschodu mogą aplikować o różne stypendia naukowe oferowane przez koreańskie instytucje rządowe i prywatne.

W Instytucie Bliskiego i Dalekiego Wschodu UJ można przystąpić do egzaminu TOPIK (testu biegłości w języku koreańskim). Jest on najpopularniejszym testem, który ma na celu sprawdzenie znajomości języka koreańskiego dla obcokrajowców. Do egzaminu można przystąpić w około 50 krajach, w tym w Polsce od 2016 r.

Studia koreanistyczne to nowość w ofercie programu studiów Uniwersytetu Wrocławskiego. Jej utworzenie w 2019 r. jest powiązane z potrzebami regionalnego i międzynarodowego rynku pracy. Studia nad kulturą i językiem Korei były obecne na Uniwersytecie Wrocławskim od 2010 r. Uruchomiono je w Instytucie Studiów Klasycznych, Śródziemnomorskich i Orientalnych. Kształcenie specjalistów z zakresu koreanistyki ma swoje szczególne uzasadnienie w regionie wrocławskim, w którym coraz liczniej działają firmy południowokoreańskie.

19 Plany studiów 2020/2021 IBiDW UJ, https://orient.uj.edu.pl/studia/plany-studiow/2020 [dostęp: 7.05.2021]. 
Znaczącym wydarzeniem w historii studiów koreanistycznych w Polsce jest niewątpliwie powołanie do życia Polskiego Towarzystwa Koreanistycznego z siedzibą w Poznaniu, działającego przy UAM. W kolejnym 2018 r., w czerwcu obchodzono uroczyście 15-lecie istnienia Filologii Koreańskiej UAM. W kwietniu 2019 r. odbył się w Poznaniu na UAM pod patronatem Ambasady Republiki Korei - I Kongres Koreanistyczny: Toward Academic Cooperation: Korean Studies in Poland 2019 organizowany przez prof. UAM dr hab. Grażynę Strnad i dr. Pawła Kidę (pomysłodawców kongresu). Podczas spotkania polskich koreanistów miała miejsce uroczysta inauguracja Polskiego Towarzystwa Koreanistyczne (PTKor). W wydarzeniu tym uczestniczyli przedstawiciele największych koreanistycznych ośrodków akademickich w Polsce (Uniwersytetu Warszawskiego, Uniwersytetu Jagiellońskiego, Uniwersytetu Wrocławskiego, Uniwersytetu Śląskiego, Uniwersytetu Łódzkiego oraz gospodarze, koreaniści z UAM). Celem działalności PTKor jest utworzenie interdyscyplinarnej platformy współpracy i integracji akademickiej (wśród wykładowców, studentów i doktorantów) oraz popularyzacja studiów koreanistycznych w Polsce. W skład Zarządu Polskiego Towarzystwa Koreanistycznego wchodzą: przewodniczący: dr Paweł Kida (UAM)/kierownik Zakładu Języka Koreańskiego; wiceprzewodnicząca: prof. UAM dr hab. Grażyna Strnad (UAM); sekretarz: prof. UJ dr hab. Renata Czekalska (UJ)/kierownik Zakładu Korei; skarbnik: dr Anna Paradowska (UW)/kierownik koreanistyki.

Koreanistyka jest w Polsce młodą dziedziną nauki, jednak można zauważyć, iż coraz częściej w księgarniach pojawiają się nie tylko pozycje z literatury koreańskiej, ale wzrasta także liczba publikacji popularno-naukowych i naukowych poświęconych różnym problemom. Poznawanie egzotycznej Korei, 
Koreańczyków i koreańskości oraz popularyzacja studiów koreanistycznych w Polsce ma przed sobą przyszłość.

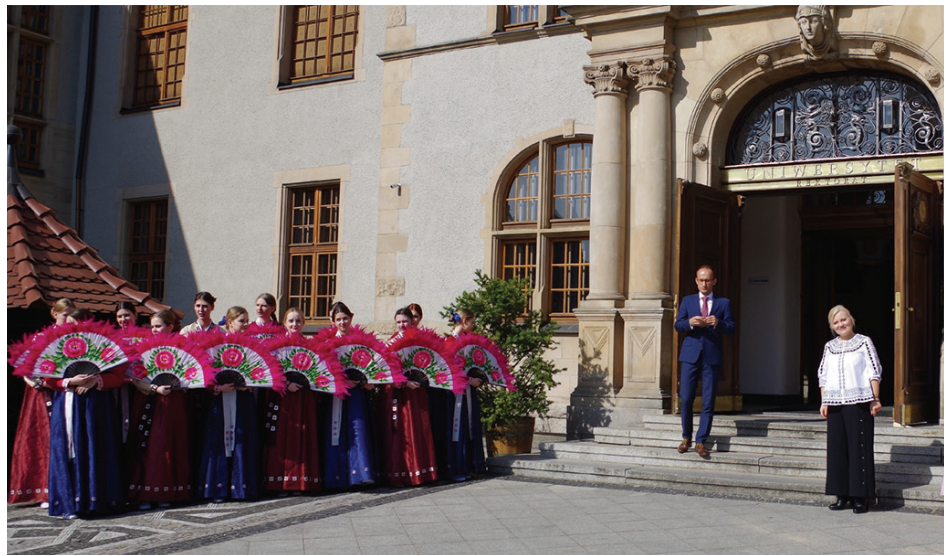

Inauguracja I Kongresu Koreanistycznego (kwiecień 2019) - Collegium Minus UAM

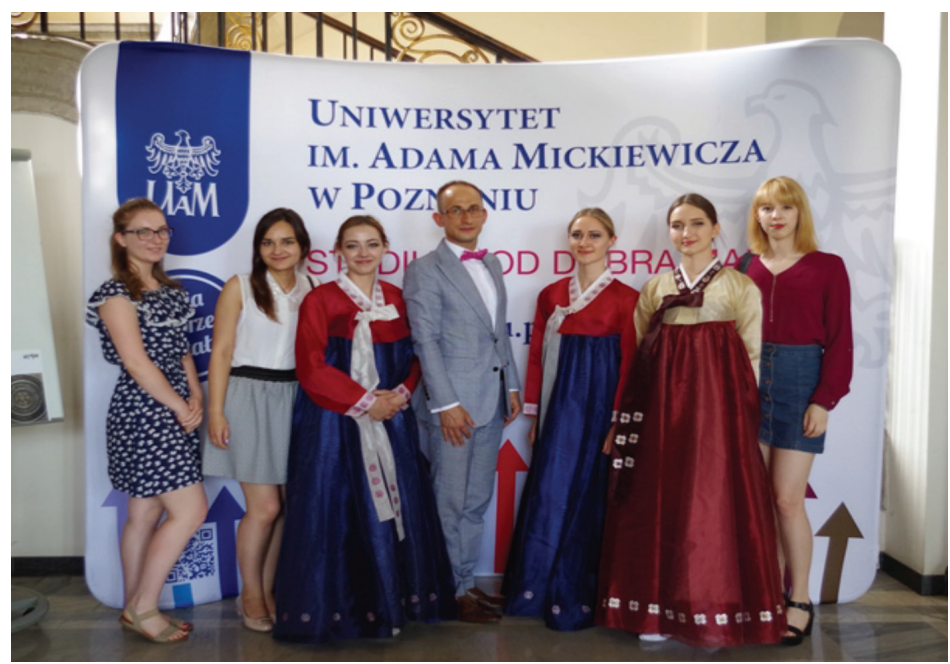

Dr Paweł Kida - kierownik Zakładu Języka Koreańskiego UAM w towarzystwie studentek Filologii Koreańskiej UAM 


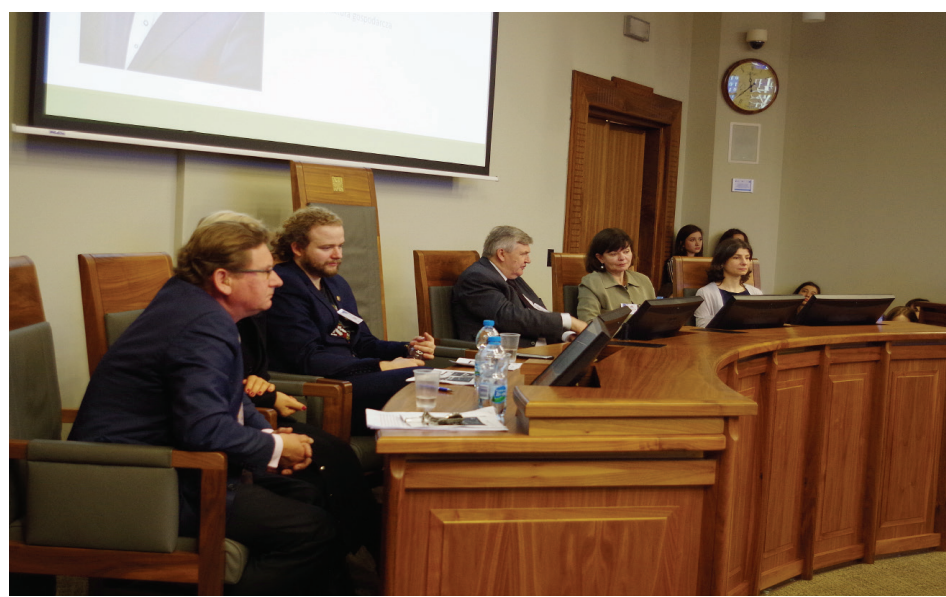

Prof. Mieczysław Sprengel (UAM), mgr Karol Starowicz (IPN) dr Marceli Burdelski (Uniwersytet Gdański), prof. Renata Czekalska (Uniwersytet Jagielloński), dr Anna Borowiak (UAM)

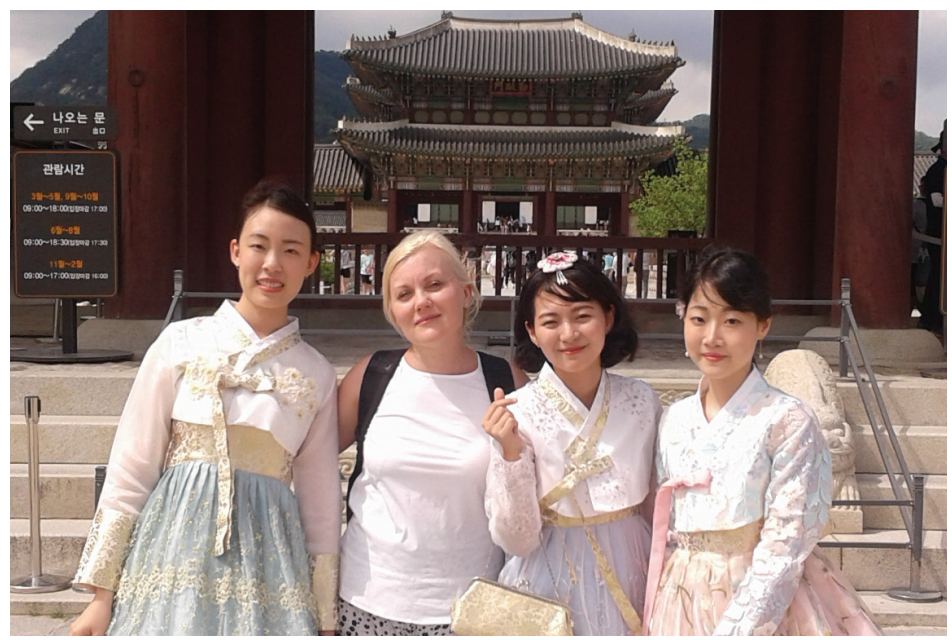

Prof. UAM dr hab. Grażyna Strnad w towarzystwie studentek z Uniwersytetu Yonsei (Korea Południowa) 


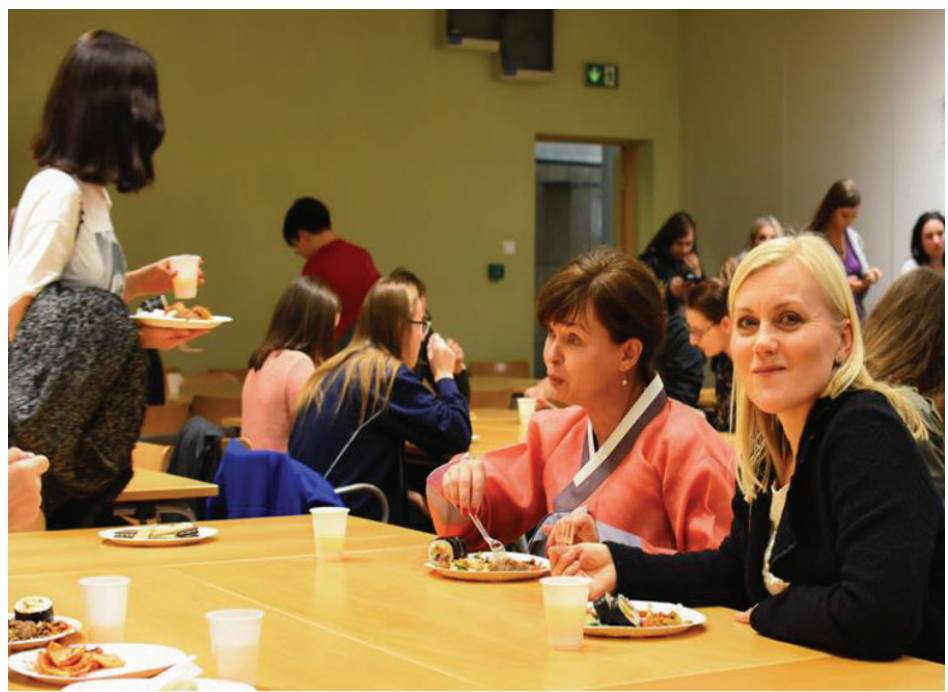

Prof. dr hab. Renata Czekalska (kierownik Zakładu Korei) oraz prof. dr hab. Grażyna Strnad dyrektor Instytutu Sejonga (Uniwersytet Jagielloński)

\section{Bibliografia}

Bańczerowski J., Korea w kręu zainteresowań Instytutu Jezykoznawstwa Uniwersytetu im. Adama Mickiewicza w Poznaniu, „Scripta Neophilologica”, t. V, Poznań 2003. Burdelski M., Stosunki Polski z obydwoma państwami koreańskimi - wczoraj - dziś - jutro, [w:] Korea w oczach Polaków. Państwo - społeczeństwo - kultura, red. J. Włodarski, K. Zeidler, M. Burdelski, Gdańsk 2012.

https://www.polsatnews.pl/wiadomosc/2020-09-27/kolejki-na-koreanistyke-inspiracja-dla-kandydatow-k-pop/. Jackson V., Does Nuclearization Impact Threat Credibility. Insights from the Korean Peninsula, [w:] Sung Chull Kim, 
Michael D. Cohen, North Korea and Nuclear Weapons. Entering The New Era of Deterrence, Washington, DC 2017. Kida P., Historia filologii koreańskiej Uniwersytetu im. Adama Mickiewicza w Poznaniu w zarysie, [w:] Meandry koreanistyki. Księga jubileuszowa z okazji 15-lecia powstania filologii koreańskiej UAM, red. P. Kida, G. Strnad, Poznań 2018.

Ogarek-Czoj H., Studia koreanistyczne w Polsce, „Przegląd Orientalistyczny" 1998, nr 3-4, http://www.koreanistyka.orient.uw.edu.pl/dhoc.html.

Rurarz J., Ksiega jubileuszowa na 75-lecie IO UW, Zaktad Japonistyki i Koreanistyki, Sekcja koreanistyki, http:// www.koreanistyka.orient.uw.edu.pl/historia.html.

Sieroszewski W., Korea. Klucz do Dalekiego Wschodu, Warszawa 1905.

Strnad G., Dzieci wojny koreańskiej, [w:] Dzieci i doświadczenia wojny. Wiek XX i XXI, red. M. Grzywacz, M. Okupnik, Poznań 2020.

Strnad G., Korea. Polityka Potudnia wobec Pótnocy w latach 1948-2008. Zmiana i kontynuacja, Poznań 2014.

\begin{abstract}
Abstrakt
Półwysep Koreański to wyjątkowe miejsce na mapie politycznej świata, znajdują się tutaj dwa państwa w których żyje podzielony naród. Problem koreański będący pozostałością zimnowojennej rywalizacji mocarstw do dnia dzisiejszego nie został rozwiązany. Koreańczycy to dumny naród, a Korea to jedno z najstarszych państw świata. Cywilizacja koreańska licząca blisko pięć tysięcy lat historii jest przedmiotem zainteresowania i fascynacji kolejnych pokoleń. Rosnąca popularność studiów koreanistycznych w Polsce sprawia, że o Korei i Koreańczykach mówi się coraz częściej. Uwagę kandydatów na studia przyciągają przede wszystkim: koreańska muzyka popu-
\end{abstract}


larna, nazywana K-popem, seriale, czyli K-dramy, koreańskie filmy, taekwondo (narodowy sport Korei), koreańska tradycja i obyczaje, egzotyczne świątynie i wartości konfucjańskie. To wszystko sprawia, że od wielu już lat młodzi Polacy chcą uczyć się języka koreańskiego, którym włada ponad 77 milionów ludzi na całym świecie. Absolwenci studiów koreanistycznych mogą liczyć zarówno na pewne zatrudnienie w kraju jak i za granicą. Znajomość języka koreańskiego, historii, kultury, sztuki czy polityki, umożliwia pracę w dyplomacji, administracji państwowej, przedsiębiorstwach koreańskich, instytucjach kulturalnych i naukowo-badawczych, biurach podróży. Przy istniejącej współcześnie skali kontaktów biznesowych, naukowych i kulturalnych zapotrzebowanie na tłumaczy i ekspertów od spraw koreańskich w różnych dziedzinach nauki jest ogromne.

Słowa kluczowe: studia koreanistyczne w Polsce, Korea Południowa, Korea Północna, edukacja uniwersytecka.

\begin{abstract}
The Korean Peninsula occupies a unique place on the political map of the world, a place where two countries of a divided nation exist. The Korean problem, a legacy of the Cold War rivalry between the great powers, has not been resolved to this day. Koreans are a proud nation, being one of the oldest countries in the world. Korean civilization, despite the fact that its history spans nearly five thousand years, is of interest to modern generations. The growing popularity of Korean studies in Poland means that Korea and Koreans are being talked about more and more often. The attention of students is primarily attracted to: Korean popular music, known as K-pop, Korean television series, i.e. K-drama, Korean movies, taekwondo (Korea's national sport), indigenous traditions and customs, exotic Buddhist temples and Confucian values. All this underscores that for many years young Poles have wanted to learn the Korean language, which is spoken by over 77 million people around the world. Korean studies graduates can count on both secure employment in Poland and abroad. Knowledge of the Korean language, history, culture, art or politics gives you the opportunity to work in diplomacy, state administration, Korean enterprises, cultural and research institutions, and travel agencies. With the current scale of business, scientific and
\end{abstract}


cultural contacts, the demand for translators and Korean experts in various fields of science is enormous.

Keywords: Korean Studies in Poland, South Korea, North Korea, university education 


\author{
Dariusz Jędrasiak \\ Uniwersytet Łódzki \\ ORCID ID: https://orcid.org/0000-0003-4070-9818
}

\title{
Dyplomacja edukacyjna w procesie kształtowania wizerunku Japonii. Studium przypadku relacji z Polską
}

\section{Wprowadzenie}

Teoretyczną podstawą podjętych badań jest szeroko pojęta problematyka dyplomacji publicznej, siły miękkiej państwa oraz jednego z jej elementów dyplomacji edukacyjnej. Podejmę próbę odpowiedzi na pytanie w jaki sposób dyplomacja edukacyjna przekłada się na polepszenie wizerunku państwa.

Po raz pierwszy pojęcie „dyplomacja publiczna” pojawiło się w pracy E. Giullon, który w 1966 r. określił ją: ,jako działania, poprzez które rządy, prywatne grupy i jednostki mogą wpływać na postawy i opinie innych narodów i ich rządów, co w konsekwencji może kształtować ich decyzje w zakresie polityki zagranicznej"1. Cull określił dyplomację publiczną jako: „zarządzanie międzynarodowym środowiskiem poprzez zaangażowanie publiczności”2. Z kolei Beata Ociepka zdefiniowała dyplomację publiczną jako: „dwustronną nastawioną na dialog, formę komunikowania międzynaro-

1 A. Henrikson, What can public diplomacy achieve?, Haga 2006.

2 N. Cull, Public diplomacy: Lessons from the Past, Los Angeles 2009. 
dowego kierowaną do publiczności zagranicznych, realizowaną przez wykorzystywanie środków przekazu i kanałów o charakterze bezpośrednim"3.

Przy definiowaniu pojęcia dyplomacji publicznej można wykorzystać elementy marketingu politycznego, w tym wizerunku państwa. Współczesne kraje, politycy w chwili obecnej wykorzystują coraz częściej w działaniach dyplomatycznych wizerunek państwa, starając się zbudować przy tym silną markę. Przywołując badania Marty Hereźniak jest to możliwe dzięki specyfice działań dyplomacji publicznej szeroko traktującej politykę i państwo. W swojej wypowiedzi dodaje: „W nowoczesnej dyplomacji coraz częściej traktuje się państwo jako przedsiębiorstwo, z własną strategią działania, wizją, promocją i wyrazistym wizerunkiem" ${ }^{\prime 4}$. Podobnie Anholt stwierdza, że w latach 90. XX w. pojawiło się pojęcie brandingu narodowego definiowanego jako „zabieganie krajów o swoje miejsce na rynku światowym w oparciu o markę narodową"5. Wreszcie w artykule Raftowicz i Filipkiewicz zwracają uwagę, że "wizerunek ten staje się bardzo ważny w kontaktach międzynarodowych i odbiorze danego kraju przez partnerów politycznych kontaktów wzajemnych. Rozpoznawalność marki kraju, jego wizerunku ma wpływ na miejsce państwa na mapie ekonomicznej świata, a co za tym idzie na jego funkcjonowanie i rozwój”'.

Podsumowując można wysnuć wniosek, że obecnie głów-

3 B. Ociepka, Dyplomacja publiczna, Wrocław 2008.

4 M. Hereźniak, Marka narodowa. Jak skutecznie budować wizerunek i reputację kraju, Warszawa 2011.

5 S. Anholt, Sprawiedliwość marek. Jak branding miejsc i produktów może uczynić kraj bogatym, dumnym i pewnym siebie, Warszawa 2006.

6 M. Raftowicz-Filipkiewicz, Branding Narodowy w Unii Europejskiej, https://www.bibliotekacyfrowa.pl/Content/37430/PDF/007.pdf [dostęp: 15.02.2021]. 
ną rolę w dyplomacji odgrywają argumenty związane z budowaniem wizerunku społecznego, opartego na wskaźnikach potencjału intelektualnego i naukowego społeczeństwa. Ważny element tych działań stanowi dyplomacja edukacyjna. W mojej opinii dyplomacja edukacyjna wciąż jest niedoceniana. Pewnie również dlatego samo pojęcie nie zostało w sposób jednoznaczny zdefiniowane, chociaż oczywiście podkreśla się, że jest to fragment dyplomacji publicznej. W swoim artykule Natalia Broś stawia tezę, że „edukacja stanowi jeden z komponentów składających się na kształt stosunków międzynarodowych"7. Budowanie sprawnego systemu edukacyjnego państwa, jego właściwe funkcjonowanie jest jednym z elementów gwarantujących rozwój społeczny, ekonomiczny i kulturowy. W ekonomii światowej edukacja jest traktowana jako czynnik kształtowania kapitału ludzkiego, społecznego i intelektualnego państwa ${ }^{8}$.

Dotychczas nie prowadzono kompleksowych badań dotyczących zależności między współpracą międzynarodową w dziedzinie oświaty, w tym kontaktów polsko-japońskich a wizerunkiem państwa. W swoich badaniach postanowiłem tę lukę uzupełnić. Główną metodą badawczą, którą wykorzystam są własne doświadczenia związane ze współpracą edukacyjną z Japończykami, prowadzoną przez jedną z łódzkich szkół średnich od 1994 r. Na podstawie zrealizowanych zadań zostaną zatem sformułowane wnioski, które pozwolą usystematyzować ten fragment działań edukacyjnych i zbadać jego wpływ na budowanie wizerunku Polski w oczach

7 N. Broś, Edukacja w dyplomacji publicznej. Cyberdyplomatyczne rozwiazania w międzynarodowym nauczaniu, "Ogrody Nauk i Sztuk” 2016, nr 6.

8 G. Wronowska, Polityka edukacyjna a potrzeby rynku pracy, „Studia Ekonomiczne" 2017, vol. 310. 
Japończyków oraz Japonii w oczach Polaków. Stawiam tezę, że współpraca edukacyjna jest nadal słabo wykorzystywanym narzędziem soft power. Wnioski z tej analizy pozwolą na dalszy rozwój kontaktów szkół i placówek oświatowych i być może będą zaczynem do zbudowania sprawnie działającego systemu tych kontaktów na szerszą skalę.

W warunkach globalizacji i szybkich przemian technologicznych nowoczesny system edukacyjny umożliwia szybki rozwój gospodarki opartej na wiedzy. Stale podnoszenie poziomu innowacyjności, wprowadzanie nowoczesnych technologii i metod zarządzania, elastyczne dostosowanie się do wymagań rynku - są ściśle powiązane z poziomem szkolnictwa9 . Takie założenia przyświecają wszystkim elitom władzy i stanowią motywację do wprowadzenia zmian i udoskonaleń w procesie kształcenia. Te elementy polityki edukacyjnej zostały przefiltrowane przez doświadczenia szkolnictwa średniego w Polsce.

\section{Polityka edukacyjna i system edukacji w Polsce i Japonii}

Polityka edukacyjna jest ważnym elementem działalności każdego państwa. Jak pisze Marzena Kletke-Milejska, „polityka edukacyjna jest to dyscyplina naukowa zajmująca się podstawami działalności w systemie edukacji oraz co najważniejsze, jest to celowa i zorganizowana działalność władz państwowych i samorządowych zapewniająca dzieciom, młodzieży i dorosłym zdobywanie wiedzy, umiejętności zawodowych, rozwijanie osobowości oraz zaspokajanie aspiracji i dą-

9 https"//ideologia.pl/system-edukacyjny-w-japonii, 2019, s. 1 [dostęp: 20.11.2020]. 
żeń"10. Ja nie użyłbym sformułowania dyscyplina naukowa, ale z całą pewnością każda władza stara się kreować wizerunek państwa poprzez umiejętnie prowadzoną politykę edukacyjną. Polityka edukacyjna jest również przedmiotem uzgodnień w działaniach wielu polityków i widoczna jest również w dokumentach programowych Unii Europejskiej ${ }^{11}$. Narzędziem do realizacji polityki edukacyjnej jest system edukacji.

System edukacji to zespół norm i zasad, na podstawie których budowane jest szkolnictwo oraz zespół przepisów prawnych stanowiących podstawę do jego funkcjonowania. Jest to również kompleks instytucji, „zbiorowości społecznych, urządzeń, organizacji, wyposażenia materialnego, a także idei i systemów wartości służących przekazywaniu »oświecenia«, czyli wiedzy o świecie, ludziach i wartościach, członkom społeczeństwa, przede wszystkim dzieciom i młodzieży ${ }^{12}$. Najlepszym wskaźnikiem jakości systemu edukacyjnego są wyniki uczniów. Przyjrzyjmy się zatem najlepszym systemom edukacyjnym na świecie według rankingu sporządzonego przez OECD.

Niektóre państwa azjatyckie, a z europejskich Finlandia, od lat przodują w międzynarodowych rankingach systemów edukacji. Uczniowie z tych państw osiągają ponadprzeciętne wyniki w testach kompetencji, a praca w zawodzie nauczyciela to prawdziwy prestiż. Na podstawie rankingu Pearsona „The Learning Curve 2014” można stwierdzić, że w pierw-

10 M. Kletke-Milejska, Zreformowany system edukacji i jego wptyw na ksztatcenie i wychowanie dzieci w publicznych szkołach podstawowych: studium politologiczne, praca doktorska, Katowice 2007.

11 Strategia na rzecz inteligentnego i równoważonego rozwoju sprzyjajacego włączeniu społecznemu, https://ec.europa.eu/eu2020/pdf/ [dostęp: 15.02.2021].

12 A. Jelonek, System edukacyjny w Polsce i Japonii, http://www.edukacja.edux.pl [dostęp: 20.11.2020]. 
szej piątce najlepszych systemów edukacyjnych na świecie znalazły się kolejno: Korea Południowa, Japonia, Singapur, Hongkong i Finlandia. W tym rankingu Polska znalazła się na dziesiątym miejscu ${ }^{13}$.

OECD (Organizacja Współpracy Gospodarczej i Rozwoju) w ostatnim opublikowanym rankingu dotyczącym poziomu szkolnictwa w poszczególnych państwach wskazała, w których z nich poziom edukacji jest najwyższy. Pierwsze cztery miejsca przypadły państwom azjatyckim. Na czele rankingu uplasowały się Chiny (Pekin, Szanghaj, Jiangsu, Zhejang), drugie miejsce zajął Singapur, trzecie Makau, a czwarte Hong Kong ${ }^{14}$.

We współczesnym, zglobalizowanym świecie, istotnym elementem są kontakty między szkołami. Działania takie, związane z zaprezentowaniem na zewnątrz, osiągnięć uzyskiwanych $w$ danej szkole stanowią ważny element promocji oraz weryfikacji i ewaluacji własnych działań edukacyjnych. Wraz z rozwojem środków telekomunikacyjnych zwiększyła się ilość kontaktów międzynarodowych. Łatwość przekazywania informacji w sieci, jej dystrybucja, spowodowały nasilenie nawiązywania kontaktów międzynarodowych. Dzięki temu powstały możliwości wspólnego realizowania projektów przez szkoły znajdujące się w różnych, często odległych krajach. Jest to o tyle istotne, że powoli kontakty te stają się elementem promocji danego miasta czy państwa. Jednocześnie budują trwałe więzi emocjonalne pomiędzy uczestnikami oraz partnerstwa między szkołami, ośrodkami, które w następstwie mogą zaowocować współpracą na

13 https://www.educationworld.in/global-review-pearson-presents-learning-curve [dostęp: 1.03.2021].

14 https://www.oecd.org/pisa/publications/pisa-2018-results.htm [dostęp: 1.03.2021]. 
skalę międzynarodową. W miarę rozwoju współpracy międzynarodowej powstaje szereg instytucji ją wspomagających zarówno w zakresie merytorycznym, jak i finansowym.

\section{Znaczenie prowadzonych badań}

Badania stanowiące podstawę niniejszego artykułu dotyczą zagadnień stosunkowo nowych. Dużo badań jest prowadzonych odnośnie do umiędzynarodowienia szkół wyższych, natomiast mało analiz dotyczy szkół średnich. W mojej opinii aktualnie ważnym elementem edukacji stają się kontakty zagraniczne między uczniami szkół z różnych krajów i one wymagają monitorowania. Kontakty te dostarczają ważnych elementów wzbogacających i uzupełniających zagadnienia realizowane przez uczniów w szkołach podczas zajęć dydaktycznych. Nowoczesne technologie komunikacyjno-informacyjne pozwalają na rozszerzenie kontaktów pomiędzy uczniami ze szkół w różnych krajach. Międzynarodowa współpraca uczniów pozwala na wymianę doświadczeń pomiędzy współpracującymi szkołami, wzajemne poznanie się oraz budowanie płaszczyzny współpracy międzynarodowej na poziomie szkolnym. Jest to bardzo istotny element kształtujący postawy młodych ludzi, co ma bezpośrednie przełożenie na ich działania w przyszłości, w dorosłym życiu.

W chwili obecnej niewiele szkół w Polsce podejmuje i realizuje kontakty ze szkołami w Japonii. Bardzo często kontakty te opierają się na bazie znajomości towarzyskich nauczycieli. Taką formę nie wyklucza dyplomacja publiczna, a nawet zakłada jej sensowność. Tym niemniej za tą konstatacją kryje się pewna trudność. Nie ma jasno określonych zasad nawiązywania kontaktów, baz danych adresowych szkół zainteresowanych kontaktami, jak jest w przypadku 
kontaktów z wieloma innymi państwami. Nie ma zasad finansowania tych spotkań i projektów.

Biorąc pod uwagę fakt coraz większego zaangażowania państw azjatyckich w politykę europejską, rosnące zaangażowanie ekonomiczne w Europie, jak najbardziej uzasadnione wydaje się zbadanie dotychczasowych działań w zakresie kontaktów między szkołami Polski i Japonii oraz wskazanie na tej podstawie kierunków rozwoju i dopracowania zasad ich funkcjonowania, co na pewno przełoży się na wzrost ich efektywności oraz zwiększenie ich natężenia. Jak było powiedziane, te relacje stanowią również ważny element dyplomacji publicznej, choć jak do tej pory mało wykorzystywany. Ułatwia wzajemne poznanie kultur oraz zachęca do nauki języków, co ułatwia komunikację.

\section{Koncepcja i plan badań}

Swoimi badaniami objąłem szkoły średnie i placówki oświatowe w Polsce, realizujące kontakty ze szkołami z Japonii. Na podstawie ankiet, które przygotowałem dla szkół chciałem uzyskać odpowiedzi na pytania:

1. Jak wygląda struktura kontaktów polsko-japońskich na poziomie szkół średnich. Jaki jest ich zasięg, charakter i częstotliwość. Czy działania te obejmują kontakty tylko na drodze wymiany informacji (jeśli tak, to czego one dotyczą, jak są intensywne i co jest ich efektem?). Czy te działania obejmują kontakty bezpośrednie uczniów, czyli wizyty w szkołach grup uczniów, pojedynczych uczniów, nauczycieli?

2. Jak wygląda sposób nawiązywania kontaktów i „szukania” partnera. Co stanowi źródło informacji dla szkół o partnerach. Czy są to źródła państwowe, biznesowe, czy też 
prywatne. Na jakiej zasadzie są one nawiązywane, czy powstają jakieś wieloletnie umowy i plany działania?

3. Jakie są źródła i sposoby finansowania działań w zakresie międzyszkolnych kontaktów polsko-japońskich. Czy środki na realizację wspólnych projektów pochodzą z budżetu państwa, samorządu, czy są to środki z biznesu lub środki własne realizujących wymianę szkół i uczestników?

4. Jaki jest zakres merytoryczny prowadzonych wspólnie działań. Czy tematyka projektów, zagadnienia opracowywane i wspólnie realizowane dotyczą tematów kulturowych, historycznych, społecznych czy innych. Jak są budowane podstawy merytoryczne projektów i czego dotyczą oraz jaki jest cel realizacji właśnie takich zagadnień tematycznych?

5. Jaki jest wpływ kontaktów i wspólnych działań edukacyjnych na kształtowanie wizerunku państwa. W jaki sposób realizacja wzajemnych kontaktów młodzieży na różnych poziomach edukacyjnych ma wpływ na wiedzę o danym kraju, znajomość jego realiów politycznych, ekonomicznych i społecznych i w jaki sposób wpływa to na wizerunek państwa jako całości?

\section{Material i metody}

Zgodnie z metodologią badań politologicznych „metoda powinna być dobrana zależnie od postawionego problemu badawczego" ${ }^{\prime 15}$.

Badania w ramach projektu obejmowały następujące działania:

15 R. Bäcker, Metodologia badań politologicznych, Warszawa 2016, s. 115 . 
- uzyskanie informacji od organów sprawujących nadzór pedagogiczny o szkołach realizujących zajęcia z języka japońskiego i kultur Dalekiego Wschodu.

Wysłane zostały pisma z prośbą o informację o placówkach realizujących w poszczególnych województwach zajęcia z języka japońskiego i kultur Wschodu do Ministerstwa Edukacji oraz Kuratoriów Oświaty jako organów sprawujących w województwach nadzór pedagogiczny nad szkołami.

- uzyskanie informacji od instytucji nadzorujących i wspomagających współpracę międzynarodową między Polską a Japonią o realizowanych przez szkoły w Polsce i Japonii wspólnych projektach.

Wysłane zostały pisma z zapytaniem o powyższe tematy do Ambasady Japonii w Polsce, Instytutu Kultury Polskiej w Tokio.

- analiza informacji internetowych oraz kontaktów własnych, które nawiązałem podczas rozmów prowadzonych przy organizacji wymian szkolnych oraz rozmów studyjnych prowadzonych w Japonii, w trakcie badań studyjnych w latach 2018-2019.

Niestety, w wyniku tych zapytań nie uzyskano satysfakcjonujących odpowiedzi. Ministerstwo Edukacji oraz Kuratoria Oświaty, opierając swoje odpowiedzi na danych zawartych w Systemie Informacji Oświatowej SIO, odpowiedziały że nie posiadają wiadomości o szkołach i placówkach edukacyjnych prowadzących nauczanie języka japońskiego i kultur Wschodu na swoim terenie.

Ambasada Japonii oraz Instytut Kultury Polskiej w Tokio zadeklarowały daleko idącą, szeroką współpracę. Jednak również nie posiadały żadnych danych na temat współpracy między szkołami z Japonii i Polski. 
Dlatego też informacji o szkołach prowadzących tego typu działania uzyskałem ze źródeł własnych oraz z Internetu. Wysłano ankiety do dwunastu placówek, o których pozyskałem informacje, że prowadzone są w nich zajęcia z języka japońskiego. Uzyskałem odpowiedź od pięciu. W ten sposób wyłoniona została grupa pięciu placówek oświatowych, w których realizowane są działania będące w kręgu zainteresowań projektu.

Wykaz placówek objętych badaniem:

\begin{tabular}{|l|l|l|}
\hline L.p. & Nazwa placówki & Adres \\
\hline 1. & II Liceum Ogólnokształcące im G. Narutowicza & $\begin{array}{l}\text { 90-031 Łódź } \\
\text { ul. Nowa 11/13 }\end{array}$ \\
\hline 2. & Liceum Ogólnokształcące przy PJATK & $\begin{array}{l}\text { Warszawa } \\
\text { ul. Szczęśliwicka } 33\end{array}$ \\
\hline 3. & Liceum Ogólnokształcące nr 8 w Zabrzu & $\begin{array}{l}41-806 \text { Zabrze } \\
\text { ul. Korczoka 98 }\end{array}$ \\
\hline 4. & $\begin{array}{l}\text { Prywatne Liceum Sióstr Nazaretanek z Oddziałami i } \\
\text { Międzynarodowymi }\end{array}$ & $\begin{array}{l}\text { 00-720 Warszawa } \\
\text { ul. Czerniakowska } 137\end{array}$ \\
\hline 5. & Miejski Dom Kultury w Lublińcu & $\begin{array}{l}\text { 42-700 Lubliniec } \\
\text { ul. Plebiscytowa 9 }\end{array}$ \\
\hline
\end{tabular}

W celu uzyskania odpowiedzi na pytania postawione w poprzedniej części artykułu została przygotowana ankieta, którą rozesłano do powyższych szkół.

Ankieta zawierała następujące pytania:

1. Od ilu lat realizowane są zajęcia z języka i kultury Japonii w Państwa szkole?

2. Jaka jest formuła realizowanych zajęć?/zajęcia pozalekcyjne, koła zainteresowań, akcje promocyjne, inne/?

3. Ilu uczniów korzysta z zajęć języka japońskiego/kultury Japonii?

3. Czy posiadają Państwo kontakty z podmiotami w Japonii?

4. W jaki sposób nawiązali Państwo te kontakty? 
5. Jakie są źródła finansowania Państwa działań?

6. Proszę podać przykładowe działania realizowane w ramach kontaktów partnerskich.

7. Co, Państwa zdaniem, może przyczynić się do zintensyfikowania wzajemnych kontaktów między szkołami z Japonii i Polski?

8. Jaki wpływ, Państwa zdaniem, mają realizowane przez Waszą Szkołę działania na budowanie jej wizerunku i wizerunku Polski w oczach japońskiego Partnera?

9. Inne uwagi, którymi chcą się Państwo z nami podzielić (trudności, sukcesy, wspólne plany itp.).

\section{Dyskusja i wnioski}

Analizując odpowiedzi respondentów należy stwierdzić, że:

Jeżeli chodzi o strukturę kontaktów polsko-japońskich na poziomie szkół średnich, ich zasięg, charakter, częstotliwość to w chwili obecnej są one realizowane w wąskim zakresie. Kontakty dotyczą przede wszystkim wymiany informacji oraz organizacji zajęć z zakresu języka japońskiego lub kultury Wschodu dla zainteresowanych uczniów. W dwóch badanych placówkach (II LO Łódź, MDK Lubliniec) zajęcia prowadzone są przez wolontariuszy z Japonii.

Zajęciami tymi objęte są różne grupy uczniów w zależności od ankietowanej placówki. Niemniej jednak można stwierdzić, że dotyczą przede wszystkim młodzieży uczącej się w tych szkołach i zainteresowanej tymi zagadnieniami. Jeżeli są zajęcia, to mają one charakter nieobowiązkowy i uczęszcza na nie od kilkunastu do kilkudziesięciu uczniów.

W trzech kolejnych przypadkach (II LO Łódź, LO przy PJATK Warszawa, Prywatne LO Sióstr Nazaretanek War- 
szawa) organizowane i realizowane były wymiany młodzieży ze szkołami z Japonii.

Jeśli chodzi o pytanie drugie to należy stwierdzić, że w zakresie nawiązywania kontaktów pomiędzy placówkami polskimi i japońskimi nie ma uporządkowanych schematów. Kontakty te nawiązywane są zarówno przy pomocy instytucji państwowych (Ambasada Japonii - LO nr 8 Zabrze), przy pomocy międzynarodowych organizacji pozarządowych (ICEA - IILO Łódź) czy też samych szkół japońskich (LO przy PJATK, LO Sióstr Nazaretanek Warszawa) lub osób prywatnych przy wykorzystaniu ich osobistych kontaktów (MDK Lubliniec). Wszystkie ankietowane podmioty zakładają kontynuację nawiązanych kontaktów lub taka kontynuacja trwa od wielu lat (II LO Łódź - od 1994 r.).

Ankiety wykazały, że nie istnieje w Polsce spójny, uregulowany program finansowania tego typu działań. Ankietowane podmioty finansują lub dofinansowują swoje działania przede wszystkim ze środków własnych (II LO Łódź, LO przy PJATK, Prywatne LO Sióstr Nazaretanek Warszawa, MDK Lubliniec), ze środków państwowych (LO nr 8 Zabrze).

Niektóre podmioty uzyskują na swoje działania dotacje ze źródeł samorządowych (II LO Łódź, MDK Lubliniec).

Działania prowadzone $\mathrm{w}$ ankietowanych placówkach swoim zakresem merytorycznym obejmują przede wszystkim naukę języka japońskiego. Zajęcia te mają charakter fakultatywny i uczestniczą w nich zainteresowani uczniowie. Oprócz tego realizowane są zajęcia z przedmiotu dodatkowego obejmującego tematy związane z Japonią i państwami Azji Wschodniej (II LO Łódź). Szeroko rozumiane zajęcia kulturowe mające na celu pokazanie młodzieży polskiej i japońskiej obyczajów, kultury, dnia codziennego i specyfiki 
państw partnerskich między innymi poprzez kontakty z rodzinami realizowane są podczas wymian (II LO Łódź, LO przy PJATK, Prywatne LO Sióstr Nazaretanek Warszawa).

Ankietowane placówki są również animatorami działań promocyjnych na swoim terenie, takich jak Dzień Kultury Japonii (II LO Łódź) czy różnorodnych imprez związanych z kulturą i sztuką Japonii (LO nr 8 Zabrze).

Dla moich badań ważna była odpowiedź na pytanie piąte. We wszystkich ankietowanych placówkach zwraca się uwagę na fakt, że uczestnicząc w kontaktach pośrednich lub bezpośrednich z japońskimi placówkami edukacyjnymi, uczniowie budują wizerunek Polski u swoich partnerów. Przy prowadzeniu tych spotkań i kontaktów organizatorami kieruje chęć, przede wszystkim pokazania wartości naszego kraju oraz co ważne, zbudowania pozytywnego wizerunku Polski jako partnera tych kontaktów. Stąd też duży bagaż elementów krajowych w działaniach (historia, kultura, sztuka, obyczajowość historyczna oraz co ważne, współczesność i przyszłość). Dzięki temu młodzież polska biorąca udział w wymianach stara się budować swój wizerunek w oczach partnerów z Japonii. W podobny sposób działa również strona japońska i japońscy uczestnicy kontaktów wzajemnych. Kreują oni również swój wizerunek, wizerunek własnego kraju w oczach polskich partnerów. Wszyscy uczestnicy tych działań deklarują ich kontynuację i zwiększenie ich zakresu.

Pomimo niewielkiej, można powiedzieć losowej próby badawczej, można stwierdzić, że wśród polskiej młodzieży istnieje zainteresowanie Japonią oraz państwami Azji Wschodniej. Stąd też organizowanie przez szkoły i placówki oświatowe w kraju szerokiego spektrum działań i zajęć zmierzających do przybliżenia tych tematów uczniom. Patrząc na to zagadnienie w kontekście zwiększania obecności krajów 
azjatyckich na terenie Europy i Polski ${ }^{16}$ jest to jak najbardziej korzystne. Na uwagę zasługuje fakt prowadzonych w tym kierunku działań przez rząd Japonii, zmierzających do rozwoju i rozszerzenia współpracy z państwami europejskimi ${ }^{17}$.

W lutym 2019 r. weszła w życie umowa o współpracy między Japonią i Unią Europejską, która otworzyła nowe możliwości dla kontaktów gospodarczych pomiędzy przedsiębiorstwami japońskimi i europejskimi ${ }^{18}$. Podpisanie umowy o współpracy zwiększa możliwości współpracy pomiędzy przedsiębiorstwami obu stron zarówno w zakresie handlu, jak i inwestycji. Otwiera to drogę do uzyskania nowych miejsc pracy dla ludzi znających specyfikę Japonii. Młodzi ludzie realizujący swoje zainteresowania w szkole, podczas zajęć międzynarodowych, mają szansę znalezienia zatrudnienia w firmach japońskich szukających kontaktów i inwestujących w Europie. Dlatego też udział w kontaktach z Japonią, uzyskiwanie wielu nowych praktycznych informacji, może zaowocować dla nich np. wybraniem dalszej edukacji na uczelniach w Japonii i uzyskania pracy w tym zakresie. Biorąc pod uwagę fakt zainteresowania rządów państw azjatyckich kontaktami naukowymi z uczelniami polskimi, pozyskiwaniem studentów z Europy jest to dla polskiego licealisty kusząca oferta, dopingująca go do uzyskiwania lepszych wyników w szkole średniej, umożliwiających mu dostanie się na uczelnię japońską. Z kolei ukończenie tej uczelni na pewno zwiększy możliwości uzyskania

16 https://www.rp.pl/artykul/730449-Azjatyckie-firmy-wybieraja-Polskę.html [dostęp: 20.11.2020].

17 A. Ziętek, K. Żakowski, O. Pietrzyk, Polityka zagraniczna Japonii, Lublin 2018.

18 Komunikat prasowy: Umowa handlowa między UE a Japonia wchodzi w życie, https://ec.europa.eu/commission/presscorner/detail/pl/IP_19 _.785 [dostęp: 1.03.2021]. 
pracy w firmach z udziałem japońskim czy innych państw azjatyckich. Dzięki temu Japonia uzyskuje też swoich „społecznych ambasadorów” w Polsce, którzy osobiście moga podzielić się, zdobytymi podczas studiów i pobytu w Japonii doświadczeniami i obserwacjami. Jest to ważny element dyplomacji publicznej, gdyż im więcej takich „ambasadorów”, tym obraz kraju staje się pełniejszy i łatwiejszy do weryfikacji z informacjami uzyskanymi poprzez przekazy medialne. Wpływa to zdecydowanie na budowanie pozytywnego wizerunku kraju. Ta nowa praktyka dotyczy wszystkich liczących się państw na arenie międzynarodowej. Przykładem takie mocarstwa, jak USA i Chiny kładą duży nacisk na kontakty młodzieży zarówno dotyczące studiów na uczelniach, jak i realizacji międzynarodowych programów edukacyjnych $^{19}$.

Ważnym staje się więc zarówno dla władz Japonii, jak i Polski wspieranie tego typu działań. Konieczne jest, o czym mówili wszyscy ankietowani, stworzenie płaszczyzny nawiązywania kontaktów dla zainteresowanych podmiotów edukacyjnych z Japonii i Polski w celu znalezienia odpowiedniego partnera do projektów. W chwili obecnej stanowi to dużą barierę dla wielu podmiotów.

Dla zwiększenia profesjonalizmu prowadzonych działań, osiągania bardziej znaczących, korzystnych dla wizerunku obu stron efektów, niezbędne jest dofinansowanie tych kontaktów w sposób systemowy. W Polsce państwowe i unijne środki finansowe skierowane są przede wszystkim na organizowanie i realizację tego typu projektów w ramach państw

19 A. Derelkowska-Misiuna, Wymiana studencka między Stanami Zjednoczonymi a Chinami jako element dyplomacji publicznej, http:// dx.doi.org/10.18778/8088-970-5.11 [dostęp: 20.11.2020]. 
Unii Europejskiej ${ }^{20}$. Nie ma funduszu dedykowanego na współpracę w zakresie edukacji na poziomie szkół średnich z państwami azjatyckimi, a z wstępnych obserwacji widać, że występuje taka potrzeba.

Powyższe badania wykazały, że istnieją trudności ze znalezieniem oficjalnych informacji na temat współpracy między placówkami z Polski i Japonii, dlatego uważam za konieczne stworzenie bazy danych takich podmiotów. Wiele inicjatyw profesjonalnie przygotowanych, wartościowych, wartych kontynuacji w szerszym spektrum oddziaływań ginie z powodu braku informacji. Inicjatywy te często realizowane przez grupy pasjonatów zainteresowanych zagadnieniami współpracy między Polską a Japonią, promowane są za pomocą mediów społecznościowych i jednak mimo ich silnego oddziaływania nie docierają do wszystkich zainteresowanych. Stąd też konieczność promowania ich w sposób profesjonalny.

Dzięki takim działaniom buduje się więzi społeczne pomiędzy państwami partnerskimi. Stają się one elementem wzajemnego poznania, budowania zaufania oraz płaszczyzną współpracy wspomagającą i wzmacniającą działania w tym zakresie prowadzone przez polityków. Powyższe wnioski stanowią próbę wstępnej analizy problemu, co zaznaczyłem w tytule pracy.

\section{Bibliografia}

Anholt S., Sprawiedliwość marek. Jak branding miejsc i produktów może uczynić kraj bogatym, dumnym i pewnym siebie, Warszawa 2006.

20 K. Sołkowicz, Program Erasmus w realizacji polityki edukacyjnej UE, http://www.irbis-nbuv.gov.ua/ [dostęp: 20.11.2020]. 
Bäcker R., Metodologia badań politologicznych, Warszawa 2016.

Broś N., Edukacja w dyplomacji publicznej. Cyberdyplomatyczne rozwiazania $w$ międzynarodowym nauczaniu, „Ogrody Nauk i Sztuk” 2016, nr 6.

Derelkowska-Misiuna A., Wymiana Studencka między Stanami Zjednoczonymi a Chinami jako element dyplomacji publicznej, http://dx.doi.org/10.18778/8088-970-5.11.

Dzierżek A., Najciekawsze fakty o najlepszych systemach edukacji na świecie, https://forsal.pl/artykuły/824241.

Henrikson A., What can public diplomacy achieve?, Haga 2006.

Hereźniak M., Marka narodowa. Jak skutecznie budować wizerunek i reputację kraju, Warszawa 2011.

https://ideologia.pl/system-edukacyjny-w-japonii.

http://pomijane.pl/najlepszy-system-edukacji-na-swiecie/. https://www.educationworld.in/global-review-pearson-presents-learning-curve.

https://www.oecd.org/pisa/publications/pisa-2018-results.htm. https://www.rp.pl/artykul/730449-Azjatyckie-firmy-wybieraja-Polske.html.

https://www.wprost.pl/swiat/506324/ogolnoswiatowy-ranking-poziomu-szkolnictwa.html.

Jelonek A., System edukacji w Polsce i Japonii - porównanie, hhtp://www.edukacja.edux.pl.

Kletke-Milejska M., Zreformowany system edukacji i jego wptyw na ksztatcenie i wychowanie dzieci w publicznych szkołach podstawowych: studium politologiczne, praca doktorska, Katowice 2007.

Komunikat prasowy: Umowa handlowa między UE a Japoniq wchodzi w życie, https://ec.europa.eu/commission/ presscorner/detail/pl/IP_19_785. 
Miłoszewska D., Trójpłaszczyznowa szachownica, Częstochowa 2010.

Ociepka B., Dyplomacja publiczna, Wrocław 2008.

Wronowska G., Polityka edukacyjna a potrzeby rynku pracy, „Studia Ekonomiczne” 2017, vol. 310.

Ziętek A., Żakowski K., Pietrzyk O., Polityka zagraniczna Japonii, Lublin 2018.

Sołkowicz K., Program Erasmus w realizacji polityki edukacyjnej UE, http://www.irbis-nbuv.gov.ua/.

Raftowicz-Filipkiewicz M., Branding narodowy w Unii Europejskiej, https://www.bibliotekacyfrowa.pl/Content/37430/PDF/007.pdf.

Strategia na rzecz inteligentnego i równoważonego rozwoju sprzyjajacego wtaczeniu społecznemu, https://ec.europa. eu/eu2020/pdf/.

\section{Abstrakt}

Artykuł jest związany z dyplomacją publiczną, siłą miękką państwa. Podstawowym pytaniem, które stawia sobie autor jest: jak współpraca w zakresie edukacji przekłada się na polepszenie wizerunku państwa?

W obecnych czasach główną rolę w dyplomacji odgrywają argumenty związane z budowaniem wizerunku społecznego, opartego na wskaźnikach potencjału intelektualnego i naukowego społeczeństwa. Ważny element tych działań stanowi dyplomacja edukacyjna. Budowanie sprawnego systemu edukacyjnego państwa, jego właściwe funkcjonowanie jest jednym z elementów gwarantujących rozwój społeczny, ekonomiczny i kulturowy państwa.

Dotychczas nie prowadzono kompleksowych badań dotyczących takich zagadnień, jak: współpraca międzynarodowa w zakresie oświaty oraz w jaki sposób przekłada się ona na polepszenie wizerunku państwa. W przypadku podjętych badań szczegółowych podobne pytanie można postawić w odniesieniu do stosunków polsko-japońskich. Pracując przez wiele lat w szkole średniej zaangażowanej od 
1994 r. w aktywne kontakty edukacyjne ze szkołami z Japonii, postanowiłem systemowo przeanalizować zrealizowane w tym czasie działania i sformułować wnioski, które pozwolą usystematyzować ten fragment działań edukacyjnych i zbadać jego wpływ na budowanie wizerunku Polski w oczach Japończyków oraz Japonii w oczach Polaków. Prace te pozwolą na dalszy rozwój kontaktów szkół i być może będą zaczynem do zbudowania sprawnie działającego systemu tych kontaktów na szerszą skalę.

Słowa kluczowe: edukacja, dyplomacja publiczna, współpraca międzynarodowa, polityka edukacyjna

\begin{abstract}
This article is linked to public diplomacy and soft power of the state. It explains how cooperation in the field of education contributes to improving the image of the state. Nowadays, the arguments relating to building a social image, based on indicators of the intellectual and scientific potential of society, play a central role in diplomacy. Educational diplomacy is a crucial element of these activities. Building an efficient state education system, its proper functioning is one of the elements that guarantee the social, economic and cultural development of the state. So far, no comprehensive research has been carried out on issues such as international cooperation in the field of education, which contributes to improving the image of the state in terms of contacts between Poland and Japan. Working for many years in a high school, since 1994 engaged in active educational contacts with schools in Japan, I decided to systematically analyze the activities implemented during this period and formulate conclusions that will systematize this area of educational activities and examine its influence on building the image of Poland in the eyes of the Japanese and Japan in the eyes of the Poles. These activities will allow schools to develop further contacts and may perhaps be an activity to build a functioning system of these contacts on a broader scale.
\end{abstract}

Keywords: education, public diplomacy, international cooperation, education policy 


\section{Beata Pietkiewicz-Pareek}

Uniwersytet Wroclawski

ORCID ID: https://orcid.org/0000-0001-8450-1707

\section{Zdalna edukacja w Indiach w czasach pandemii Covid-19}

\section{Wprowadzenie}

Pandemia Covid-19 wymusiła na całym świecie zamknięcie szkół i reorganizację tradycyjnego szkolnictwa. Nigdy w historii edukacji nie mieliśmy do czynienia z masowym zamknięciem szkół i przejściem na zdalną edukację. Nigdy $\mathrm{w}$ historii nie byliśmy zmuszeni do niewychodzenia $\mathrm{z}$ domu, zaprzestania spotykania się z rodziną, przyjaciółmi, a nawet najbliższymi sąsiadami. Nowa sytuacja zmusiła nas do podjęcia nowych działań, do zastanowienia się nad tym, jak edukacja w okresie pandemii ma wyglądać. Jak dotąd nikt nie przygotował nas na to wyzwanie, dlatego społeczność akademicka na całym świecie musi zmierzyć się z tym problemem i wypracować nowe standardy dla zdalnej edukacji. Nie jest to łatwe bez bezpośredniego kontaktu dziecka z nauczycielem, bez dostępu do Internetu, komputera czy nawet bez dostępu do prądu. Do końca 2020 r. na Covid-19 na świecie zachorowało ponad $90 \mathrm{mln}$ ludzi, z czego prawie $2 \mathrm{mln}$ zmarło. Jednym z krajów najbardziej dotkniętych koronawirusem są Indie, do końca grudnia 2020 r. zachorowało tam ponad 10 mln ludzi, z czego ponad 152 tys. zmarło. Plasuje to Indie na drugim miejscu pod względem zachorowalności na Covid-19 na świecie, zaraz po Stanach Zjednoczonych. 
Artykuł ten przybliża polskiemu czytelnikowi sytuację w szkolnictwie indyjskim w okresie pandemii. Ukazuje walkę Hindusów z ograniczeniami, takimi jak niemożność nawiązania bezpośredniego kontaktu nauczyciela z uczniem, brak dostępu do Internetu, brak dostępu do bibliotek i pomocy naukowych, brak dostępu do szkolnej infrastruktury, a także niemożności korzystania z bezpośredniej pomocy rówieśników. Rząd Indii stara się ulepszyć istniejące programy, np. IGNOU, a także stworzyć programy bazujące na zasobach dostępnych najbiedniejszym mieszkańcom Indii, by uniknąć sytuacji, gdy dzieci rezygnują z nauki i różnice między biednymi a bogatymi jeszcze bardziej się uwidaczniają. Do takich programów należą: Platforma Smile Social Media Interface for Learning Engagement, Platforma SWAYAM, SWAYAM PRABHA.

\section{Nauczanie zdalne - jego specyfika w kontekście indyjskim}

W Indiach ponad 320 mln uczniów zostało zmuszonych do pozostania w domu po tym, jak rząd ogłosił zamknięcie szkół związane z pandemią koronawirusa w marcu 2020 r. Natychmiast zaczęto organizować zajęcia zdalne, zapominając, że większość obywateli nie ma dostępu do internetu, a nawet i prądu, nie wspominając, że posiadanie komputera jest dla nich nieosiągalnym marzeniem. Zgodnie $\mathrm{z}$ danymi z lipca 2020 r., zaledwie 50\% mieszkańców Indii miało dostęp do Internetu, co oznacza, że na ponad miliard ludzi, tylko $560 \mathrm{mln}$ ma dostęp do Internetu. Jest to znaczący progres, jeżeli weźmiemy pod uwagę fakt, iż w 2007 r. zaledwie 4\% mieszkańców miało dostęp do Internetu. Dostęp do Internetu w Indiach jest uzależniony od takich czynników jak płeć czy status społeczny. W 2019 r. 290 mln użytkowników pochodziło z re- 
gionów wiejskich, a 337 mln z terenów miejskich. Większość z użytkowników to ludzie pomiędzy 20. a 29. rokiem życia. Logowali się głównie z telefonów komórkowych. Możliwość korzystania $\mathrm{z}$ taniego Internetu jest zasługą między innymi kampanii Digital India, której celem jest dostarczenie Internetu 4G do wszystkich wiejskich regionów Indii. Facebook jest najpopularniejszym medium społecznościowym w Indiach, liczącym ponad 280 mln użytkowników ${ }^{1}$.

Stworzenie programów do zdalnego nauczania wymaga czasu, specjalistów i zazwyczaj pewnych nakładów finansowych. Instytucje edukacyjne, które do tej pory prowadziły zajęcia zdalne, są przygotowane na czas pandemii, by kontynuować swoją pracę. W gorszym położeniu znalazły się te placówki, które do tej pory nigdy nie miały do czynienia z edukacją zdalną na masową skalę, a nauczyciele nie są wyposażeni w nawet najprostszy sprzęt do prowadzenia zajęć online. W obecnej chwili Indie muszą zmierzyć się z trzema wyzwaniami, by zapewnić ciągłość edukacji. Po pierwsze, edukacja to proces ciągły. By zdobyć wiedzę musi uczeń zaliczyć najpierw jeden rozdział, potem drugi itd. Nie można niczego przeskoczyć, pominąć. Po drugie, muszą zapewnić wszystkim uczniom dostęp do materiałów, z których mają korzystać. Żaden uczeń nie może zostać pominięty w dostępie do edukacji. Nie każdy musi mieć zajęcia online, ale każdy musi mieć książki, zeszyty czy inne materiały, które często zostały w szkole, kiedy te zostały z dnia na dzień zamknięte. Po trzecie i chyba najważniejsze należy mieć na uwadze dobrostan dziecka. Izolacja, brak kontaktu z rówieśnikami czy rodziną negatywnie wpływają na dzieci. W tych trudnych czasach powinniśmy wszyscy o tym pamiętać.

1 statista.com/topics/2157/internet-usage-in-india/ [dostęp: 30.12.2020]. 


\section{Komunikacja synchroniczna i asynchroniczna - wady i zalety}

\begin{tabular}{|c|c|c|c|c|}
\hline & \multicolumn{2}{|c|}{ SYNCHRONICZNA } & \multicolumn{2}{|c|}{ ASYNCHRONICZNA } \\
\hline & ZALETY & WADY & ZALETY & WADY \\
\hline 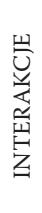 & $\begin{array}{l}\text { Spotkanie w czasie } \\
\text { rzeczywistym } \\
\text { z nauczycielem } \\
\text { i uczniami z klasy, } \\
\text { brak izolacji i uczu- } \\
\text { cia osamotnienia }\end{array}$ & $\begin{array}{l}\text { Koordynacja } \\
\text { spotkań ze strony } \\
\text { nauczyciela i obec- } \\
\text { ność } \\
\text { wszystkich w tym } \\
\text { samym czasie. }\end{array}$ & $\begin{array}{l}\text { Nauczyciel i studen- } \\
\text { ci mogą inicjować } \\
\text { rozmowę 24/7 za } \\
\text { pomocą różnych } \\
\text { narzędzi, jak: e-mail, } \\
\text { forum, czat. }\end{array}$ & \begin{tabular}{|l|} 
Odpowiedź nie \\
przychodzi na- \\
tychmiast. Trzeba \\
czekać, co prowadzi \\
do przerw w komu- \\
nikacji z nauczycie- \\
lem czy uczniami, co \\
zaburza dialog.
\end{tabular} \\
\hline 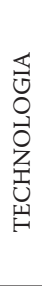 & \begin{tabular}{|l|} 
Sesje audio video \\
na żywo wymagają \\
określonego sprzętu
\end{tabular} & \begin{tabular}{|l|} 
Wymaga zaawanso- \\
wanej technologii, \\
dostępu do szybkie- \\
go internetu, kame- \\
ry internetowej, na \\
co nie każdy uczeń \\
czy nauczyciel może \\
sobie pozwolić. \\
Czasami na jedną \\
rodzinę przypada \\
jeden komputer.
\end{tabular} & $\begin{array}{l}\text { Wymaga mniejszych } \\
\text { wymagań sprzę- } \\
\text { towych. Zdjęcia } \\
\text { odrobionych zajęć } \\
\text { można wysłać sms- } \\
\text {-em o każdej porze } \\
\text { dnia i nocy. } \\
\text { W nocy Internet jest } \\
\text { szybszy, można więc } \\
\text { przesyłać większe } \\
\text { pliki. }\end{array}$ & $\begin{array}{l}\text { Problemy tech- } \\
\text { niczne prowadzą } \\
\text { do frustracji nie } \\
\text { tylko nauczycieli } \\
\text { i uczniów, ale także } \\
\text { rodziców. Często } \\
\text { uniemożliwiają } \\
\text { uczestnictwo w za- } \\
\text { jęciach. }\end{array}$ \\
\hline 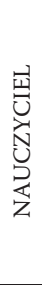 & $\begin{array}{l}\text { Nauczyciel funk- } \\
\text { cjonuje zgodnie } \\
\text { z planem zajęć, } \\
\text { organizuje spotkania } \\
\text { w aplikacji, podnosi } \\
\text { swoje kompetencje, } \\
\text { przygotowuje mate- } \\
\text { riały i treści kształ- } \\
\text { cenia adekwatne do } \\
\text { sytuacji pandemii. }\end{array}$ & $\begin{array}{l}\text { Nauczyciel musi być } \\
\text { przygotowany na } \\
\text { przypadki niemoż- } \\
\text { ności nawiązania } \\
\text { kontaktu z uczniami } \\
\text { z powodów nieza- } \\
\text { leżnych od nich, } \\
\text { w związku z czym } \\
\text { musi mieć plan } \\
\text { awaryjny. Wymaga to } \\
\text { dodatkowego czasu. }\end{array}$ & $\begin{array}{l}\text { Materiał jest przy- } \\
\text { gotowany wcześniej } \\
\text { i wysyłany uczniom } \\
\text { w dowolnym ter- } \\
\text { minie. }\end{array}$ & \begin{tabular}{|l} 
Koordynowanie \\
pracy uczniów jest \\
utrudnione, gdyż \\
każdy odsyła wyko- \\
nane zadania w do- \\
wolnym czasie. Nie \\
jest do końca pewny \\
kto je wykonał.
\end{tabular} \\
\hline $\begin{array}{l}Z \\
\text { Z } \\
\text { บ }\end{array}$ & $\begin{array}{l}\text { Uczeń ma kontakt } \\
\text { z nauczycielem i ró- } \\
\text { wieśnikami, dzięki } \\
\text { czemu nie czuje się } \\
\text { odizolowany. }\end{array}$ & $\begin{array}{l}\text { Uczeń zmuszony } \\
\text { jest do przestrze- } \\
\text { gania planu lekcji. } \\
\text { Jeśli nie uda mu się } \\
\text { połączyć z grupą, } \\
\text { opuści zajęcia i bę- } \\
\text { dzie musiał je jakoś } \\
\text { odrobić. }\end{array}$ & $\begin{array}{l}\text { Uczeń może } \\
\text { pracować we } \\
\text { własnym zakresie, } \\
\text { w dogodnym dla } \\
\text { siebie czasie. Wysyła } \\
\text { odrobione zadania } \\
\text { i dostaje informacje } \\
\text { zwrotne. }\end{array}$ & $\begin{array}{l}\text { Uczeń może oszukać } \\
\text { nauczyciela i wysłać } \\
\text { lekcje zrobione } \\
\text { przez rodziców lub } \\
\text { rówieśników. }\end{array}$ \\
\hline 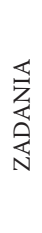 & $\begin{array}{l}\text { Zadania przekazy- } \\
\text { wane są na bieżąco } \\
\text { i nauczyciel ma } \\
\text { możliwość ocenić } \\
\text { ich wykonanie } \\
\text { w krótkim czasie, } \\
\text { mając pewność kto } \\
\text { je wykonał. }\end{array}$ & $\begin{array}{l}\text { Ciężko jest w krót- } \\
\text { kim czasie sprawdzić } \\
\text { przez kamerkę } \\
\text { kilkanaście prac. } \\
\text { Muszą być przesłane } \\
\text { mailem, sms-em lub } \\
\text { przy wykorzystaniu } \\
\text { innego komunika- } \\
\text { tora. }\end{array}$ & $\begin{array}{l}\text { Zadania mogą być } \\
\text { sporządzone w for- } \\
\text { mie quizów, gier czy } \\
\text { innych zabaw, które } \\
\text { uczniowie rozwiążą } \\
\text { w dowolnym mo- } \\
\text { mencie. }\end{array}$ & $\begin{array}{l}\text { Zadania wykonane } \\
\text { mogą być przez oso- } \\
\text { by obce, nauczyciel } \\
\text { nie ma możliwości } \\
\text { kontroli nad tym, } \\
\text { kto je wykonał. }\end{array}$ \\
\hline
\end{tabular}

Źródło: Z.D. Mulla, V. Osland-Paton, M.A. Rodriguez, E. Vzaquez, S.K. Plavsic, Novel coronavirus, novel faculty development 
programs: rapid transition to eLearning during the pandemic, „J. Perinat Med." 2020, nr 48 (5), s. 446-449.

Do najpopularniejszych platform wykorzystywanych przez indyjskich nauczycieli w edukacji synchronicznej zaliczyć można zoom i Microsoft Teams. Jednakże, jak nauczyciele sami przyznają, nie każdy uczeń ma konto mailowe na Outlook, w związku z czym korzystają z darmowej wersji Zoom. Nauczyciel tworzy wydarzenie i zaprasza do niego uczniów, wysyłając im hasło do spotkania. Ma możliwość bezpośredniej rozmowy z uczniem, widzi go i na bieżąco może kontrolować jego pracę. Małe jest prawdopodobieństwo, że przy włączonej kamerze uczniowi uda się ściągnąć. Jednocześnie nauczyciel ma możliwość nagrania lekcji lub egzaminu, co pozwala na jej odtworzenie w razie potrzeby.

Nauczanie asynchroniczne daje nauczycielowi możliwość przygotowania materiału i przesłanie go w dogodnym dla siebie czasie, natomiast uczniom rozwiązywanie zadań wtedy, kiedy mają czas. Daje to zarówno nauczycielowi, jak i uczniom swobodę w pracy nad nowym materiałem. Jedną z wad jest niemożność kontrolowania ucznia, nauczyciel nie może być do końca pewny czy wychowanek wykonał pracę samodzielnie, czy ktoś mu pomagał.

\section{Aplikacje online na indyjskim rynku edukacyjnym}

Aplikacje online pomagają uczniom nie tylko uzyskać dostęp do materiałów, ale także pozwalają im uczestniczyć w zajęciach i wchodzić w interakcje z nauczycielami podobnie jak w sali lekcyjnej. Poniżej przedstawiona została lista inicjatyw rządowych uruchomionych w celu usprawnienia edukacji zdalnej w czasie pandemii. 
W celu zaangażowania nauczycieli w walkę z pandemią koronawirusa rząd Indii uruchomił platformę Igot z modułem szkoleniowym o nazwie "Zintegrowane Rządowe Szkolenie Online dla pracowników rządowych”. Celem programu jest zwiększenie zdolności pracowników rządowych do skutecznego radzenia sobie z pandemią Covid-19. Kursy uruchomiono nie tylko dla nauczycieli, ale również dla lekarzy, pielęgniarek, funkcjonariuszy rządu stanowego, urzędników, policji, wolontariuszy i innych ludzi z pierwszej linii walki z koronawirusem. Platforma ma za zadanie szkolenie nauczycieli online, przygotowanie ich do prowadzenia zdalnej edukacji, przygotowywania quizów, wykonywania zajęć edukacyjnych w celu promowania kreatywności i krytycznego myślenia, a przede wszystkim w celu zapewnienia ciągłości nauczania związanego z realizacją programu nauczania w obecnych czasach. Materiały edukacyjne na portalu można uzyskać po zalogowaniu się na platformę wykorzystując jedynie telefon komórkowy ${ }^{2}$.

Platforma Smile Social Media Interface for Learning Engagement to innowacyjny program Departamentu Edukacji Szkolnej w Radżastanie, którego celem jest zapewnienie edukacji zdalnej uczniom pozostającym w domu na skutek wybuchu pandemii koronawirusa. Rada gminy lub sołtys (Gram Panchayat) otrzymuje wybrane materiały edukacyjne, które następnie przekazywane są rodzicom uczniów. Program Smile efektywnie wykorzystuje także media społecznościowe i aplikację WhatsApp na niespotykaną dotąd skalę. Umożliwiają one kontakt z rodzicami i wieloaspektowy rozwój uczniów zamkniętych w domu na skutek pandemii. Ważną rolę w dystrybucji materiałów edukacyjnych

2 https://igot.nic.in/ [dostęp: 30.12.2020]. 
pełni administrator, czyli urzędnik w Radzie Gminy, gdyż to właśnie on jest odpowiedzialny za przekazanie materiałów edukacyjnych za pośrednictwem aplikacji WhatsApp. W tym celu utworzono dwie grupy odbiorców pomocy edukacyjnych: nauczycieli i rodziców. Rodzice odgrywają bardzo ważną rolę w programie Smile, gdyż to właśnie oni muszą przekazać materiały otrzymane na telefon komórkowy swoim dzieciom. Dzięki temu mają świadomość, jakie treści codziennie dostają ich dzieci, mogą ingerować w ich naukę w domu, kontrolować ich postępy, a także poszerzyć swoją wiedzę o nowe wiadomości. Obecnie materiały edukacyjne tworzone i wybierane są w kontekście stanowym, a w przyszłości będą opracowywane w oparciu o państwowe programy nauczania. Nauczyciele są aktywnym partnerem $\mathrm{w}$ procesie tworzenie materiałów edukacyjnych. Ich rolą jest aktywna pomoc uczniom, obserwacja, analiza ich postępów w samodzielnym zdobywaniu wiedzy. Przygotowują i wysyłają również własne materiały rodzicom, jak również nagrywają własne filmiki video. Dzięki skutecznej realizacji Programu Smile Radżastan ma szansę odnieść ogromne korzyści w zapewnieniu uczniom kształcenia w czasach pandemii ${ }^{3}$.

Platforma SWAYAM zapewnia dostęp do kursów organizowanych między innymi przez IGNOU Indira Gandhi National Open University. Wysokiej jakości materiały dydaktyczne zamieszczone na platformie umożliwiają studentom zdobycie wiedzy w interesującej ich tematyce w przeciągu kilku miesięcy. Uczestnicy kursów uzyskują dostęp do tekstów, filmów i forum dyskusyjnego, a po zakończeniu kursu dostają certyfikat. Program SWAYAM został zainicjowany

3 https://vikaspedia.in/education/education-best-practices/remote-learning-initiatives-in-india/remote-learning-initiatives-in-rajasthan. 
przez rząd Indii w celu zapewnienia trzech głównych zasad polityki edukacyjnej: dostępności, równości i jakości. Celem tych działań jest udostępnienie najlepszej jakości materiałów dydaktycznych dla wszystkich, zwłaszcza dla tych pozostających poza głównym nurtem gospodarki opartej na wiedzy. Co najważniejsze, wszystkie kursy są darmowe, a ich uczestnicy mogą sami wybrać czas na ich realizację ${ }^{4}$.

Platforma telewizyjna SWAYAM PRABHA to 34 kanały telewizyjne $\mathrm{z}$ dostępem 24 godziny na dobę, prezentujące co 4 godziny nowe materiały dydaktyczne. Na każdym kanale dzieci i młodzież mogą uczetsniczyć w zajęciach lekcyjnych. Każdy kanał przypisany jest innej klasie, każda klasa ma swój tygodniowy plan lekcji. Dzięki temu dzieci pozbawione dostępu do internetu mogą uzyskać pomoc w przyswojeniu nowego materiału. Zajęcia realizowane są zgodnie z podstawami programowymi wyznaczonymi dla poszczególnych klas. Tego typu forma zdalnej edukacji cieszy się w Indiach ogromną popularnością i dla wielu jest jedyną możliwością zachowania ciągłości nauczania ${ }^{5}$.

Indira Gandhi National Open University został powołany w 1985 r. Jego celem jest dostarczenie edukacji na najwyższym poziomie. W $1987 \mathrm{r}$. liczył ponad 4,5 tys. studentów, obecnie zaś ponad $4 \mathrm{mln}$. W 2004 r. otwarty został kanał EduSat, szerzący ideę edukacji dla wszystkich. Model zdalnej edukacji opiera się na pięciu filarach: Internecie, samokształceniu, konsultacji z nauczycielami, mediach elektronicznych i satelicie EduSat z programami edukacyjnymi. Aby zapewnić dostęp do kursów osobom do tej pory marginalizowanym IGNOU opracowało specyficzną strategię

4 https://swayam.gov.in/about [dostęp: 30.12.2020].

5 https://www.swayamprabha.gov.in/ [dostęp: 30.12.2020]. 
pozyskiwania studentów. Po pierwsze, mogą oni wybrać dowolne kursy, bez posiadania odpowiednich kwalifikacji, rezygnując z egzaminów wstępnych. Po drugie, kursy tłumaczone są na języki regionalne. Po trzecie, oferuje krótkoterminowe kursy specjalistyczne, podnoszące kwalifikacje dla nauczycieli, inżynierów, pracowników administracji i innych zawodów. Po czwarte, IGNOU oferuje zróżnicowane czesne, tak aby każdego było stać na oferowane kursy. Jednocześnie ukończenie kursu i zdany egzamin końcowy pozwala na uzyskanie certyfikatu lub stopnia naukowego uznawanego w całych Indiach. Pozwala to osobom z obszarów wiejskich, kobietom, plemionom rejestrowanym i najniższym kastom na zdobycie wykształcenia ${ }^{6}$.

\section{Nauczanie zdalne w okresie pandemii w percepcji uczniów i nauczycieli}

W początkowej fazie, zaraz po zamknięciu szkół, uczniowie czuli się szczęśliwi, ponieważ zyskali czas na zabawę. Dopiero gdy zdali sobie sprawę z płynących ograniczeń ich zadowolenie zmieniło się w lęk o dalszą przyszłość. Wśród opinii samych uczniów dominowało poczucie osamotnienia. Większość dzieci miała trudności z przystosowaniem się do nowych warunków. Nie mogli nawiązać połączenia z nauczycielem z powodu słabego Internetu lub jego braku. Dzieci przestały systematycznie się uczyć, a rodzice nie mieli czasu lub umiejętności, by pomóc im w nadrabianiu zaległości. Po pewnym czasie część dzieci zerwała kontakty z nauczycielem. Nie miały one możliwości technicznych, by nawiązać kontakt z nauczycielem online, a część z rodziców

6 https://www.ignou.ac.in [dostęp: 30.12.2020]. 
nie miała dostępu do nowoczesnych telefonów, by odsyłać smsem odrobione zadania. Ponieważ pandemia wybuchła nagle ani nauczyciele, ani dzieci nie mogli się przygotować do realizacji zajęć w domu. Nauczyciele, podobnie jak dzieci, nie dysponowali dostępem do wysokiej jakości technologii i Internetu. W rezultacie część z nauczycieli ograniczyła się do przesyłania zadań do odrobienia smsami. Rodziło to ogromne niezadowolenie nie tylko wśród samych uczniów, ale także ich rodziców. Po przejściu na zdalną edukację synchroniczną, nauczyciele zaobserwowali bardzo niską frekwencję wśród uczniów podczas zajęć. Słaba jakość obrazu i dźwięki utrudnia interakcję?.

\section{Wykluczenie cyfrowe w Indiach}

Wykluczenie cyfrowe nastąpiło na skutek nierównomiernego rozprzestrzeniania się nowoczesnej myśli technologicznej na świecie. Rozbudowa sieci informatycznych nabrała tempa jedynie w państwach wysoko rozwiniętych, natomiast państwa rozwijające się pozostały daleko w tyle. Zdaniem A. Jastrzębskiej i W. Jastrzębskiej istotą wykluczenia cyfrowego jest podział społeczeństwa na osoby posiadające dostęp do Internetu i nowoczesnych technologii telekomunikacyjnych oraz na pozbawionych tej możliwości ${ }^{8}$. Najczęściej niemożność uczestnictwa w zajęciach wynika z braku dostępu do urządzenia lub brak sprzętu na wyłączność. Ro-

7 Jena P.K., Online learning during lockdown period for COVID-19 in India, „International Journal of Multidisciplinary Educational Research” 2020, vol. 9.

8 A. Jastrzębska, W. Jastrzębska, Wykluczenie cyfrowe - przyczyny, zagrożenia i bariery jego pokonania. Studium przypadku, „Nierówności Społeczne a Wzrost Gospodarczy" 2012, nr 25, s. 92. 
dzeństwo musi dzielić się komputerem z rodzicami. Brak dostępu do kamery internetowej i drukarki nie pozwala na pełne uczestnictwo w zajęciach i przygotowanie materiałów do zajęć. Ogromnym problemem jest ograniczony dostęp do Internetu i jego limit. W wielu domach rodzice nie są w stanie pomóc dzieciom w pracy zdalnej, nie umieją obsłużyć komputera lub programów służących do nauki zarówno synchronicznej, jak i asynchronicznej. W mieszkaniach brakuje pomieszczeń, by każdy mógł pracować w ciszy.

Według danych Internet World Stats w 2020 r. dostęp do internetu miało ponad 90\% mieszkańców Ameryki Północnej, 87\% Europy, 70\% mieszkańców Bliskiego Wschodu czy Południowej Ameryki, 59\% Azjatów i 47\% mieszkańców Afryki ${ }^{9}$. W Indiach ${ }^{10}$ W maju 2020 r. na 1380004385 mieszkańców, z Internetu korzystało $560 \mathrm{mln}^{11}$. Autorzy raportu UNESCO twierdzą, że pomimo wysiłków zmierzających do zapewnienia wszystkim dzieciom dostępu do zdalnej edukacji, aż $465 \mathrm{mln}$ dzieci na świecie nie ma dostępu do Internetu, a co za tym idzie, nie ma możliwości korzystania

9 https://www.internetworldstats.com/stats.htm [dostęp: 30.12.2020].

10 Systemy pomocowe w Indiach obecnie są w stanie rozpoznać osoby wykluczone cyfrowo, poprzez cyfrowe rejestry identyfikacji oparte na biometrii. W kraju od kilku lat wdraża się system cyfrowej tożsamości Aadhaar, który umożliwia dotarcie poprzez smartfony do ponad miliarda osób, co ma szczególne znaczenie na obszarach wiejskich. Dzięki temu ponad 50\% Hindusów ma możliwość skorzystania ze świadczeń pomocowych. Przyśpieszająca na skutek pandemii digitalizacja czyni dostęp do Internetu jednym z dóbr podstawowych i niedługo może zostać zaliczona do istotnych praw człowieka. UNESCO i ITU (Międzynarodowa Unia Telekomunikacyjna będąca agendą ONZ) powołały do życia Komisję Zrównoważonego Rozwoju Szerokopasmowego Internetu, której celem jest podłączenie do sieci 75\% globalnej populacji do 2025 r. Jednakże bez umiejętności wykorzystania Internetu umiejętności cyfrowe staną się jednym z kluczowych czynników polaryzacji na świecie.

11 https://www.internetworldstats.com/stats3.htm [dostęp: 30.12.2020]. 
z edukacji. W wielu społecznościach marginalizowanych nauczyciele nie mają kontaktu nawet z 90\% uczniów. Te same badania pokazują, że $90 \%$ dzieci podczas pandemii nie ma żadnej pomocy w domu przy lekcjach, ani ze strony rodziców, ani rodzeństwa. W rezultacie przestają się uczyć i kontaktować z nauczycielami ${ }^{12}$.

\section{Zakonczenie}

Jednym z największych wyzwań przed jakim stoją Indie i inne państwa rozwijające się jest zapewnienie równego dostępu do zdalnej edukacji wszystkim dziewczynkom. Obecnie według danych UNESCO aż 10\% dziewczynek jest zagrożona porzuceniem szkoły. Pandemia Covid-19 dotyka je szczególnie mocno, co sprawia, że zdobycze edukacji poczynione w ostatnich dekadach są zagrożone. Pandemia powoduje również wzrost przemocy na tle płciowym, wczesne zawieranie małżeństw i ciąże, co skutecznie uniemożliwi w przyszłości dziewczynkom kontynuację nauki i zdobycie zawodu $^{13}$. Na długo przed wybuchem pandemii wiadomo było, że stres w domu zwiększa prawdopodobieństwo przemocy i znęcania sie nad dziećmi. Obecna pandemia Covid-19 wymuszając na dorosłych i dzieciach spędzanie większej ilości czasu w domu podczas kwarantanny, doprowadziła do gwałtownego wzrostu przemocy domowej stając się w pewnym sensie "niewidzialną epidemią" nie tylko w Indiach, ale i na całym świecie. Ograniczenia związane z przemieszczaniem się dają dorosłym jeszcze więcej

12 https://unesdoc.unesco.org/ark:/48223/pf0000373992 [dostęp: 30.12.2020].

13 https://apa.sdg4education2030.org/index.php/building-back-better-girls-education-times-covid-19-asia-pacific [dostęp: 30.12.2020]. 
okazji do krzywdzenia dzieci. Odizolowane od nauczycieli, szkolnych przyjaciół, pracowników socjalnych i bezpiecznej przestrzeni szkolnej, dzieci tracą możliwość do zgłaszania tych incydentów. Jednocześnie niemożność zarabiania, ograniczenie dostępu do pracy oraz podstawowych towarów i usług, ewokuje dodatkowy stres i podsyca frustrację oraz agresję. Wiele rodzin doświadcza braku bezpieczeństwa ekonomicznego i żywnościowego, co skłania je do przedwczesnego wydawania córek za mąż, by zmniejszyć liczbę osób do wyżywienia ${ }^{14}$.

Rekomendacje na przyszłość:

1. Należy zapewnić platformy internetowe o zwiększonym bezpieczeństwie i środkach ochronnych, zwłaszcza w przypadku narzędzi do wirtualnego uczenia się.

2. Należy zapewnić szybkie łącze internetowe, aby poprawić płynny dostęp dla wszystkich, w tym osób uczących się z grup defaworyzowanych i rodzin o niskich dochodach. Rząd Indii powinien zapewnić darmowe urządzenia elektroniczne wszystkim uczniom z biednych terenów wiejskich i społecznościom marginalizowanym. Zapewnienie dostępu do Internetu dzieciom z ubogich gospodarstw domowych niewątpliwie zmniejszy przepaść cyfrową w Indiach.

3. Wszyscy powinni przestrzegać nowych wytycznych wydanych przez UNICEF i partnerów, aby zapewnić dzieciom bezpieczeństwo podczas zajęć online.

4. Szkoły powinny monitorować edukację w Internecie podczas prowadzenia zajęć online.

14 O. Blomqvist, S. Chughtai, T. Rahman, Covid-19 pandemic lessons from Asia-Pacific. How the region's societes - and their children - can emerge stronger from crisis, London 2020, s. 15-17. 
5. Rodzice powinni współpracować z dziećmi, aby ustalić zasady dotyczące tego, jak, kiedy i gdzie można korzystać z Internetu.

6. Rząd powinien podjąć niezbędne kroki w celu przeszkolenia wszystkich interesariuszy edukacji na internetowej platformie edukacyjnej w celu usprawnienia zdalnej edukacji.

7. Nauka online nie jest dostępna dla wszystkich, w tym dla ubogich i defaworyzowanych grup społecznych. Rząd/instytucje edukacyjne powinny więc podjąć niezbędne kroki, aby zminimalizować tę przepaść między uczniami uprzywilejowanymi i nieuprzywilejowanymi.

8. Uczniowie i nauczyciele muszą znać komunikatory internetowe, takie jak poczta e-mail, tablice dyskusyjne i pokoje rozmów przed dołączeniem do zajęć online.

\section{Bibliografia}

Blomqvist O., Chughtai S., Rahman T., Covid-19 pandemic lessons from Asia-Pacific. How the region's societes - and their children - can emerge stronger from crisis, London 2020.

Jastrzębska A., Jastrzębska W., Wykluczenie cyfrowe - przyczyny, zagrożenia i bariery jego pokonania. Studium przypadku, „Nierówności Społeczne a Wzrost Gospodarczy" 2012, nr 25.

Jena P.K., Online learning during lockdown period for COVID-19 in India, „International Journal of Multidisciplinary Educational Research" 2020, vol. 9.

Mulla Z.D., Osland-Paton V., Rodriguez M.A., Vzaquez E., Plavsic S.K., Novel coronavirus, novel faculty develop- 
ment programs: rapid transition to eLearning during the pandemic, „J. Perinat. Med.” 2020, nr 48 (5).

https://apa.sdg4education2030.org/index.php/building-bac-

k-better-girls-education-times-covid-19-asia-pacific. https://www.ignou.ac.in.

https://igot.nic.in/.

https://www.internetworldstats.com/stats.htm.

https://www.swayamprabha.gov.in/.

https://www.statista.com/topics/2157/internet-usage-in-in$\mathrm{dia} /$.

https://swayam.gov.in/about.

https://unesdoc.unesco.org/ark:/48223/pf0000373992.

https://vikaspedia.in/education/education-best-practices/ remote-learning-initiatives-in-india/remote-learning-initiatives-in-rajasthan.

\begin{abstract}
Abstrakt
Edukacja w Indiach od wieków opierała się jedynie na tradycyjnych metodach nauczania. Pandemia na całym świecie wymusiła zamknięcie szkół i przejście na zdalne nauczanie. Wymagało to reorganizacji metod nauczania i odejście od tradycyjnej dydaktyki na rzecz pracy zdalnej. Artykuł opiera się na analizie dokumentów, artykułów i raportów zamieszczonych w Internecie, a także na wywiadach przeprowadzonych przez telefon $\mathrm{z}$ nauczycielami hinduskimi $\mathrm{w}$ okresie od marca 2020 do grudnia 2020 r. Celem artykułu jest zapoznanie polskiego czytelnika z procedurami przyjętymi przez rząd Indii w celu usprawnienia procesu nauczania/uczenia się w czasie pandemii, zwłaszcza wykorzystania narzędzi i platform internetowych pomocnych w pracy zdalnej. Ważnym elementem badań było zebranie opinii nauczycieli na temat funkcjonowania nauczania zdalnego w najbiedniejszych regionach Indii.
\end{abstract}

Słowa kluczowe: zdalna edukacja, pandemia, Covid-19, Indie 


\begin{abstract}
Education in India has relied heavily on traditional teaching methods. The worldwide pandemic has forced schools to close down and prompt to distance (remote) learning methods. Because of this, the education system has reorganization the popular traditional teaching and didactics methods by favoring to distance learning work. The article describes the comprehensive analysis of distance learning educational methods during the pandemic period based on the documents, articles and reports posted on the Internet, as well as on telephone interviews with Indian teachers from March 2020 to December 2020. The aim of the article is to acknowledge the Polish teachers and readers to familiar with the procedures adopted by the Indian government to improve the teaching process and learning methods during a pandemic period, especially the use of online tools and platforms helpful to conduct the distance learning works. An important element of this research paper is the collections of the teachers' opinions on the functioning of distance learning in the schools located in the villages and poorest regions of India.
\end{abstract}

Keywords: e-learning, pandemy, Covid-19, India 


\section{Renata Ziobro}

Uniwersytet Jagielloński

ORCID ID: https://orcid.org/0000-0002-9508-0394

\section{Hell Joseon - neologizm czy zjawisko społeczne we współczesnej Republice Korei?}

\section{Wprowadzenie}

Współczesną Koreę Południową określa się wieloma różnymi sformułowaniami. „Tygrys azjatycki”, „kraj spokojnego poranka”, „krewetka pomiędzy wielorybami” to tylko niektóre z nich. Jednak od niedawna funkcjonuje nowe, enigmatyczne określenie - Hell Joseon. Jest ono popularne w zwłaszcza wśród młodego pokolenia Koreańczyków. Pojawiają się zatem pytania co ta nazwa oznacza, skąd się wzięła i co Korea ma tak naprawdę wspólnego z piekłem (ang. hell - piekło). Zastanawia również fakt czy jest to wyłącznie popularny neologizm czy nazwa ta odnosi się do autentycznego zjawiska. Żeby jednak móc na nie odpowiedzieć, należy najpierw pochylić się nad charakterystyką dawnego państwa koreańskiego, określanego mianem Joseon.

\section{Historyczne królestwo Joseon}

Królestwo Joseon, trwające od 1392 r. do 1910 r., było ostatnim, a jednocześnie najdłużej panującym państwem koreańskim. Joseon sprawowało władzę przez ponad 500 lat, co 
czyni go najdłuższą konfucjańską dynastią na świecie ${ }^{1}$. Żeby utrzymać i ugruntować władzę, założyciel dynastii Joseon, generał Yi Seonggye potrzebował oparcia innego niż tylko militarne. Do tej pory tę rolę pełnił buddyzm, lecz w królestwie Joseon jego miejsce zajął neokonfucjanizm, który został uznany za ideologię państwową. Ta stosunkowo nowa doktryna, autorstwa chińskiego filozofa Zhu Xi, została wprowadzona do Korei w ostatnich latach panowania dynastii Goryeo. Kładła nacisk na relacje społeczne, wyjaśniała również w sposób metafizyczny pochodzenie człowieka i świata ${ }^{2}$. Neokonfucjanizm jest nazywany filozofią osiągania harmonii społecznej. Jednym z jej głównych założeń jest to, że instytucje i praktyki idealnej wspólnoty ludzkiej odzwierciedlają niezmienne prawa rządzące ruchami kosmosu. Dlatego dzięki odpowiednim praktykom społecznym, jednostki mogą uzyskać duchową jedność z niebem. Stosunki społeczne w neokonfucjanizmie są zdefiniowane na wszystkich poziomach społecznych i mają służyć harmonijnej integracji jednostek w zbiorową całość, odzwierciedlającej harmonię naturalnego porządku. $Z$ tego względu praktyka neokonfucjanizmu zwraca szczególną uwagę na hierarchię $\mathrm{w}$ relacjach międzyludzkich oraz na indywidualną samokontrolę $e^{3}$ Z początku dogmaty i praktyki neokonfucjańskie były obecne głównie wśród wyższych klas, jednak z czasem rozprzestrzeniły się na całe społeczeństwo ${ }^{4}$.

1 D.R. Woolf (red.), A Global Encyclopedia of Historical Writing, New York-London 1998, s. 513.

2 J. Rurarz, Historia Korei, Warszawa 2009, s. 213-214.

3 A.M. Savada, W. Shaw (red.), South Korea: A Country Study, Washington 1990, s. 88-89.

4 C.W. Sorensen, D. Baker (red.), Political Uses of Confucianism in North Korea, „The Journal of Korean Studies” 2011, vol. 1, nr. 16, s. 66-67. 
Neokonfucjanizm z Joseon kładł duży nacisk na strukturę i pochodzenie rodziny, a także na patrylinearny i patriarchalny autorytet i porządek, co mogło zapewnić całemu społeczeństwu pożądaną harmonię i uporządkowanie. W związku z istotnym znaczeniem hierarchii oraz statusu, poważną rolę w okresie panowania Joseon pełnił podział na klasy społeczny, który był dosyć rygorystycznie przestrzegany. Społeczeństwo koreańskie było podzielone na cztery warstwy, tj. yangban, czyli uczeni-urzędnicy, chungin, klasa pośrednia, sangmin, czyli pospólstwo głównie pracujące na roli oraz cheonmin - niewolnicy i ludzie spoza kast ${ }^{5}$. Yangbani byli to w najściślejszym znaczeniu urzędnicy cywilni i wojskowi, jednak z czasem zaczęto nazywać tak całą elitę i arystokrację państwa Joseon. Była to szlachta wychowana na Pięcioksiągu konfucjańskim, a kształcenie obejmowało literaturę chińską, filozofię i metody zarządzania państwem. By można było nazywać się yangbanem, należało zdać egzaminy urzędnicze, ale nie tylko, gdyż potrzebny był także odpowiedni rodzinny rodowód, potwierdzający dobre pochodzenie. Swój status yangbani utrzymywali i potwierdzali poprzez piastowanie wysokich urzędów. Byli znacznie bogatsi od reszty społeczeństwa, posiadali duże posiadłości i niewolników 6 . Kolejną warstwą byli chungin, co dosłownie oznacza ludzi pośrednich. Ta klasa składała się z niższego szczebla urzędników technicznych, którzy byli wykwalifikowani w jednej dziedzinie, tj.: geomancja, prawo, rachunkowość, księgowość, astronomia, tłumaczenia, medycyna ${ }^{7}$. Do chungin zaliczali się również lokalni urzędnicy admini-

5 J. Rurarz, op.cit. s. 220.

6 A.M. Savada, W. Show (red.), op.cit,. s. 91-92.

7 J. Rurarz, op.cit. 
stracyjni, którzy mimo niskiego statusu byli niezbędni do funkcjonowania państwa ${ }^{8}$. Największą grupą społeczną za czasów dynastii Joseon było pospólstwo, zwane też sangmin. Stanowili oni około 75\% całego społeczeństwa i zajmowali się głównie rolnictwem, choć byli wśród nich także rzemieślnicy i handlarze. Mieli oni obowiązek płacić podatki, odrabiać pańszczyznę, a także zasilać wojsko w razie pospolitego ruszenia. Oprócz uprawy swoich pól, dzierżawili również ziemię od yangbanów, produkowali żywność i inne dobra konsumpcyjne, dorabiali sobie także w rzemiośle. Ze względu na swój niski status byli pozbawieni wielu przywilejów i uprawnień ${ }^{9}$. Jednak najniżej w hierarchii klasowej znajdowali się cheonmin. Byli to głównie niewolnicy, ale też osoby spoza kast, tacy jak rzeźnicy, obrabiający skóry czy uliczni artyści. W skład tej grupy wchodziły także osoby wykonujące mało prestiżowe, a nawet podłe zawody, a więc szamani, kaci, szewcy, artystki kurtyzany - gisaeng, żałobnicy, więźniowie i skazani. Co więcej, ze względu na swoją niską rangę żyli poza resztą społeczeństwa, a ich status może być porównywalny do kasty nietykalnych w Indiach ${ }^{10}$. System klas był w Joseon bardzo rygorystycznie przestrzegany do tego stopnia, że używano plakietek identyfikacyjnych zwanych hopae, na których było wyszczególnione imię oraz przynależność do grupy społecznej. Bardzo ciężko było również o podniesienie swojego statusu, a ruch między klasami był bardzo utrudniony. Było to związane z lojalnością, jedną z najważniejszych wartości neokonfucjanizmu. Dopiero w późnym okresie panowania Joseon, Koreańczycy

8 M.J. Seth, A History of Korea: From Antiquity to the Present, Lamham 2010, s. 170-171.

9 A.M. Savada, W. Show (red.), op.cit., s. 93.

10 M.J. Seth, op.cit. s. 167-169. 
rozpoczęli próby poprawy rangi na szeroką skalę poprzez wykupywanie urzędów czy fałszowanie rejestrów rodzinnych $^{11}$.

\section{Dziedzictwo kulturowo-historyczne we współczesnym społeczeństwie koreańskim}

Mimo że od upadku dynastii Joseon minęło już ponad sto lat, a Korea Południowa stała się jednym z najszybciej rozwijających i modernizujących się państw na świecie, nie ma wątpliwości, że wpływy z dawnego królestwa są współcześnie nadal bardzo widoczne. Jednym z najważniejszych dziedzictw pozostawionych przez dynastię Joseon, które w dalszym ciągu odgrywa ogromną rolę we współczesnym społeczeństwie koreańskim jest neokonfucjanizm. Okazało się, że nie jest on tylko konserwatywną i sztywną ideologią praktykowaną kiedyś przez yangbanów, tylko holistycznym systemem, który rządzi codziennym życiem Koreańczyków, bez względu na przemiany i modernizacje. Pomimo szybkiego rozwoju technologicznego nie dało się zrezygnować z tej tradycyjnej ideologii, gdyż stała się ona $\mathrm{w}$ istocie sposobem życia, a nie tylko czysto teoretyczną filozofią. Tak jak w okresie Joseon, tak i współcześnie kładzie się nacisk na normy zachowania, które mają prowadzić do harmonii w społeczeństwie ${ }^{12}$. To właśnie harmonia jest pojęciem przewodnim w stosunkach międzyludzkich, przez

11 Yong Ik Lee, Korean Society depicted in its Folklore - Goryeo and Joseon period, World History at KMLA, https://www.zum.de/whkmla/ sp/0607/yongik/Yongiklee.html\#Joseon [dostęp: 14.03.2019].

12 T. Śleziak, The Role of Confucianism in Contemporary South Korean Society, „Rocznik Orientalistyczny” 2013, t. 1, nr. 66, s. 31, 45-46. 
co w obecnych czasach już dzieci w przedszkolach uczą się o tym określonym porządku, a także o wadze uprzejmości i poszanowania grupy. Neokonfucjańska lojalność oraz praca na rzecz grupy, a co więcej budowanie własnej tożsamości w oparciu o wspólnotę, a nie jednostkę jest stale praktykowane w dzisiejszej Korei. To właśnie poczucie przynależności do określonej grupy, a tym samym do narodu, jest nie tylko jednym z powodów ekonomicznego sukcesu Korei, ale także żywej kultury popularnej. Wiele z wprowadzonych za czasów dynastii Joseon wartości neokonfucjańskich, takich jak etykieta, normy, stosunki i relacje międzyludzkie przetrzymały próbę czasu i nadal się utrzymują, choć $\mathrm{w}$ trochę zmienionej formie ${ }^{13}$.

Wyraźny wpływ neokonfucjanizmu we współczesnym społeczeństwie jest zauważalny przede wszystkim w relacjach społecznych, które bazują na relacjach rodzinnych, a ich neokonfucjański rdzeń pozostał nienaruszony. Więzy międzyludzkie są tak jak w dynastii Joseon opierane na bazie zależności, takich jak stopień pokrewieństwa, wiek, płeć, status społeczny czy wykształcenie. Tak samo również ustalona jest dosyć sztywna hierarchia społeczna, z czym wiąże się nacisk na grupę oraz pozycje i związki łączące jej członków. Jednostka nie stanowi indywiduum, bowiem jest tylko częścią uwikłaną wzajemnymi relacjami z grupą ${ }^{14}$. We współczesnym społeczeństwie nadal widoczna jest także dominacja mężczyzn, zarówno w strukturach rodzinnych, jak ich w miejscach pracy.

13 N. Levi, The Impact of Confucianism in South Korea and Japan, „Acta Asiatica Varsoviensia” 2013, nr 26, s. 11-14.

14 R. Iwicka, Czy kultura koreańska zatopiła Sewol?, Kultury Wschodu w świecie procesów globalizacyjnych, red. P. Mróz, M. Ruchel, A.I. Wójcik, Kraków 2015, s. 117-119. 


\section{Współczesna Korea - Hell Joseon}

Termin Hell Joseon jest nowym sformułowaniem, które z internetowego slangu szybko zakorzeniło się w języku koreańskim. Pojawiło się ono po raz pierwszy w 2015 r. na forum internetowym „DC inside”, a od tego czasu w błyskawicznym tempie zostało podchwycone przez pozostałe media i rozpowszechnione pośród Koreańczyków, stając się jednym z najczęściej używanych zwrotów głównie przez młode pokolenie ${ }^{15}$. Na wyrażenie składają się dwa słowa, "hell” (z ang. piekło) oraz „Joseon”. Hell użyte jest tu, by uwypuklić wszystkie negatywne i przytłaczające cechy współczesnego społeczeństwa południowokoreańskiego. Z kolei Joseon odnosi się do opisanego wcześniej ostatniego państwa koreańskiego. Jednak w jego pejoratywnym znaczeniu, przywołując ówczesny ścisły podział klasowy, brak mobilności społecznej, nieudolne rządy czy podporządkowanie dynastii Ming ${ }^{16}$. Po złożeniu w całość, neologizm ten określa współczesną Koreę jako piekielne miejsce, przyrównując problemy i warunki w niej panujące do dawnej dynastii Joseon. Jest to przede wszystkim nadal obecna, ściśle określona struktura oraz klasy społeczne, które tak jak w królestwie Joseon, definiują jednostkę i jej możliwości sukcesu. Status ekonomiczny jest właściwie przypisany z góry od narodzin, a jego zmiana jest równie niemożliwa jak w historycznym

15 Minyoung Lee, "Escape from Hell-Joseon": A Study of Korean Long-term Travelers in India, „Korean Anthropology Review” 2019, nr 3, s. 59.

16 Jiyoon Kim, South Korean Youth in Crisis Implications for Political Leadership, „Georgetown Journal of Asian Affairs” 2016, s. 39. 
$J_{o s e o n}{ }^{17}$. Między klasami istnieją duże dysproporcje, a tylko nieliczni dobrze urodzeni, tak jak dawniej yangbani, mają szansę na godne życie. Reszta społeczeństwa musi zmagać się z surową rzeczywistością, gdzie przetrwanie jest wyzwaniem, a wszechobecna konkurencja i bezrobocie są na porządku dziennym. Piekielnym wydaje się także fakt, że bez względu na wykonaną ciężką pracę i włożony wysiłek, praktycznie nie da się polepszyć swojego statusu i wspiąć się po drabinie społecznej, nie dają one żadnej gwarancji na sukces $^{18}$. Dlatego też termin Hell Joseon określa współczesną Koreę jako piekielne królestwo feudalne, które utknęło w XIX wieku, a społeczeństwo koreańskie jako regresywne, w którym nadal praktycznie nie liczy się nic poza odziedziczonym statusem.

Na pierwszy rzut oka Korea Południowa wydaje się jedną z potęg światowych, więc pojawia się pytanie skąd wzięło się tak negatywne określenie. Jest jedenastą największą gospodarką (według PKB nominalnego w 2017 r.), z siódmą co do wielkości armią, a także piątym państwem na świecie według wielkości eksportu. Jednak życie obywateli wygląda zgoła inaczej. Pomimo faktu, że Korea Południowa określana jest jako przypadek szybkiego wyjścia z kryzysu azjatyckiego z 1997 r., to odcisnął on głębokie i destrukcyjne piętno na koreańskim społeczeństwie. Zmienił on znacząco strukturę dystrybucji dochodów, zatrudnienia i produkcji, a także ukształtował możliwości alternatywnych źródeł dochodu

17 Sojeong Park, Misogyny in Hell-Joseon: An Intersectional Approach to the Misogyny of South Korean Society, The Asian Conference on Cultural Studies 2017 Official Conference Proceedings, Seoul National University, Korea Południowa, s. 6.

18 Eun Chae Park, Selling Successful Bodies: the construction of female beauty ideals on the Websites of Korean cosmetic surgery clinics, MA (60 EC) Asian Studies History, Arts \& Culture of Asia, 2018, s. 21-22. 
oraz mechanizmy nagradzania ekonomicznego. Pierwszym i bezpośrednim skutkiem kryzysu było masowe bezrobocie, jednak długoterminowo spowodował on znaczne nierówności ekonomiczne oraz polaryzację dochodów i aktywów. Co więcej, rząd koreański według zaleceń Międzynarodowego Funduszu Walutowego, przyjął politykę wysokich stóp procentowych, co jeszcze bardziej poszerzyło dysproporcję pomiędzy bogatymi i biednymi. Na przestrzeni ostatnich lat z powodu zmniejszenia się zarobków i wzrastającej liczby pracowników niepełnoetatowych, ilość osób żyjących poniżej granicy ubóstwa wzrosła znacząco z 3,16\% w 1996 r. do $9,42 \%$ w 2000 r. ${ }^{19}$ Ponadto przed kryzysem azjatyckim aż $80 \%$ procent Koreańczyków uważało, że należy do klasy średniej, jednak po kryzysie ich liczba zmalała do $28 \%{ }^{20}$. Obecnie coraz większa ilość Koreańczyków zmaga się z problemami gospodarczymi, gdyż bogactwo gromadzi się w nielicznych rękach. Według raportu Funduszu Walutowego z 2016 r., spośród wszystkich państw Azji i Pacyfiku, Korea Południowa cechuje się największą nierównością dochodów. Biedniejsza połowa obywateli posiada jedynie $2 \%$ aktywów kraju, natomiast najbogatsze 10\% koreańskiego społeczeństwa posiada aż $66,4 \%$ bogactwa ${ }^{21}$. Podobnie wygląda sytuacja z PKB, które w 76\% pochodzi z dziesięciu największych koreańskich konglomeratów. Dla porównania, w Japonii 80\% PKB wnoszą małe i średnie przedsiębiorstwa,

19 Kwang Yeon Shin, Class and Income Inequality in Korea, „Korea Journal" 2004, s. 6-7.

20 Youngmi Kim, Hell Joseon: Polarization and Social Contention in a Neo-liberal Age, [w:] Korea's Quest for Economic Democratization, red. idem, London 2018, s. 3.

21 Ang Hwee Min, S. Korea's young lament inequality in their society, „Thestraitstimes”, 7.01.2018, https://www.straitstimes.com/asia/s-koreasyoung-lament-inequality-in-their-society [dostęp: 16.04.2019]. 
a duże firmy, takie jak Sony, Toyota czy Panasonic wnoszą mniej niż $20 \%{ }^{22}$.

Mimo że Korea Południowa wlicza się do państw OECD (Organizacji Współpracy Gospodarczej i Rozwoju), czyli krajów stosunkowo dobrze rozwiniętych, to wskaźnik postępu społecznego znacznie różni się od pozostałych państw z tego zrzeszenia. Wydatki socjalne w 2018 r. stanowiły w Korei zaledwie 11,1\% PKB, co plasuje ją daleko za średnią OECD wynoszącą 20,1\%. Dla porównania, państwem przeznaczającym najwięcej PKB na wydatki społeczne była Francja (31,2\%), natomiast w Polsce procent ten wyniósł 21. Co więcej, pośród innych państw OECD Korea plasuje się prawie na samym końcu we wskaźnikach szczęścia, dobrobytu i zadowolenia z życia. Stoi za tym bez wątpienia zniekształcony system podatkowy, który przynosi korzyść wyłącznie najbogatszym klanom, brak odpowiedniej opieki socjalnej, konkurencja i rywalizacja od najmłodszych lat czy bezrobocie wśród młodych ${ }^{23}$. Według danych z 2016 r. stopa bezrobocia wśród osób między 20.-29. rokiem życia wynosi aż 12,5\%, z kolei inne źródła mówią nawet o jednej trzeciej koreańskiej młodzieży bez pracy, mimo że aż $69 \%$ z nich ma wykształcenie wyższe ${ }^{24}$. Jednak to podział klasowy jest głównym źródłem terminu Hell Joseon. Uważa się, że to właśnie klasa jest przeważającym czynnikiem

22 Youngmi Kim, op.cit.

23 No-ja Park, "Hell Joseon” - a country where sleepless toil brings no mobility, „Hankyoreh”, 6.10.2015, http://english.hani.co.kr/arti/english_edition/e_national/711631.html [dostęp: 3.03.2019].

24 Sungeun Chung, The Rise of Self-deprecating Terms Such as "Hell Chosun" and "Dirt Spoon" among the Young Generations in Korea, Korea Economic Institute of America, http://keia.org/rise-self-deprecatingterms-such-\%E2\%80\%9Chell-chosun\%E2\%80\%9D-and-\%E2\%80\%9Cdirtspoon\%E2\%80\%9D-among-young-generations-korea [dostęp: 4.03.2019]. 
generującym nierówności ekonomiczne, a społeczeństwo koreańskie jest świadome wzrastającego podziału i dysproporcji dochodowych. Brak mobilności społecznej i poprawienia swojej pozycji oraz powiększająca się przepaść pomiędzy bogatymi a biednymi powodują niezadowolenie i gniew Koreańczyków ${ }^{25}$. Zdają sobie oni sprawę, że w Korei istnieją niejako dwie rzeczywistości, jedna dostępna dla osób z odpowiedniej klasy, a druga dla reszty. W miejsce niezadowolenia pojawia się również poczucie beznadziei i rozpacz, jako że sytuacji nie da się poprawić przez wysiłek oraz pracę. Ściślej mówiąc „wysiłek” (w języku koreańskim noryeok) jest jednym z najbardziej znienawidzonych słów, gdyż jest postrzegany jako obłudne zagranie klas wyższych i rządzących, by społeczeństwo nadal wierzyło, że dzięki uczciwej pracy istnieje szansa na godne i sprawiedliwe ży$\mathrm{cie}^{26}$. W tej sytuacji nie dziwią wyniki internetowej ankiety przeprowadzonej przez Joongang Tongyang Broadcasting Company (JTBC), według której aż 88\% z 21 tys. ankietowanych młodych Koreańczyków stwierdza, że nienawidzi Korei Południowej i rozważa emigrację. Natomiast aż 93\% uważa, że wstydzi się swojego kraju ${ }^{27}$.

Zjawisko Hell Joseon jest niezwykle szerokie i obejmuje praktycznie całe społeczeństwo. Wszystkie pokolenia są w pewnym stopniu dotknięte jednym z problemów tego „Piekielnego Królestwa”. Niektóre trudności zazębiają się z innymi, a ich rozwiązaniem jest tylko początkiem kolejnego problemu, tworząc błędne koło utrapienia. Złożoność i obszerność Hell

25 Eun Chae Park, op. cit.

26 Se Woong Koo, Korea, Thy Name is Hell Joseon, „Korea Exposé”, http://www.koreaexpose.com/korea-thy-name-is-hell-joseon/\#, [dostęp: 21.10.2018].

27 Ang Hwee Min, op. cit. 
Joseon obrazuje dobrze ilustracja stworzona przez koreańskich internautów. Jest to stworzona w stylu Tolkiena czy też Boscha grafika, zatytułowana „Hell Joseon - Mapa Piekielnego Półwyspu". Podstawa mapy została zapożyczona z World of Warcraft, internetowej gry fabularnej, kiedyś bardzo popularnej w Korei Południowej. Jednak idea Hell Joseon nie jest tylko grą a rzeczywistym problemem koreańskiego społeczeństwa.

Ilustracja 1. Mapa Hell Joseon

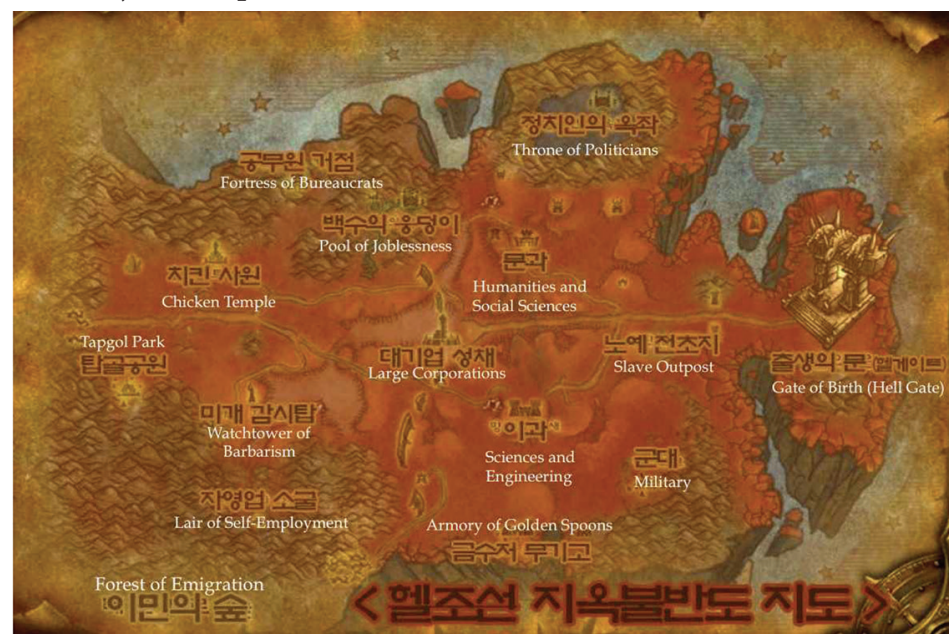

Źródło: Se Woong Koo, Korea, Thy Name is Hell Joseon, „Korea Exposé", http://www.koreaexpose.com/korea-thy-name-is-hell-joseon/\# [dostęp: 21.10.2018].

Według mapy już same narodziny są równoznaczne z wejściem do piekła, a wskazuje na to Brama Narodzin, zwana też Bramą Piekieł (ang. Gate of Birth/Hell Gate). Od początku swojego życia zostaje się niewolnikiem systemu, który dyktuje i porządkuje koleje losu (Slave Outpost - pl. Placówka Niewolników). Celem wszystkich młodych jest dostanie się do 
Dużych Korporacji (ang. Large Corporations), które znajdują się w sercu piekła, a droga do nich prowadzi przez ciężką i żmudną edukację. Na mapie rozróżnione są dwa kierunki studiów: nauki ścisłe i inżynieria (ang. Sciences and Engineering) oraz nauki humanistyczne i społeczne (ang. Humanities and Social Studies). Jednak po tych drugich ścieżka wiedzie nie w stronę korporacji, lecz bezpośrednio do Basenu Bezrobocia (ang. Pool of Joblessness), czyli kolejnego problemu, z którym zmagają się Koreańczycy w Hell Joseon. Warto również zwrócić uwagę na wojsko (ang. Military), które jest obowiązkową placówką dla praktycznie wszystkich mężczyzn, a jak to jest pokazane na mapie, blokuje edukację i zatrzymuje na drodze do kariery zawodowej. Problemom zwykłych ludzi przyglądają się politycy ze swojego Tronu (ang. Throne of Politicians), a także Arsenał Złotych Łyżek (ang. Armory of Golden Spoons), czyli osób urodzonych w zamożnych, wpływowych rodzinach, omijających cały system. Niektóre jednostki, by ratować się przed bezrobociem starają się dotrzeć do Lasu Biurokratów (ang. Forest of Bureaucrats), startując w trudnych egzaminach na urzędników państwowych. Jednak dla wielu jedynym przeznaczeniem jest Świątynia Kurczaka (ang. Chicken Temple), czyli prowadzenie popularnej, a jednocześnie najmniej prestiżowej i słabo dochodowej działalności gospodarczej w Korei, jaką jest budka ze smażonym kurczakiem. Jeszcze jednym wyjściem jest Matecznik Samozatrudnienia (ang. Lair of Self-employment), jednak taka samowystarczalność wiąże się z życiem na marginesie społeczeństwa. Końcem wędrówki po tej przygnębiającej krainie jest tak zwany Tapgol Park, w którym zbierają się biedni seniorzy, by zjeść darmowy posiłek wydany przez organizacje charytatywne. Jedyną ucieczką wydaje się być Las Emigracji (ang. Forest of Emigration), czyli opuszczenie Korei i poszukiwanie szczęścia 
poza tą piekielną krainą ${ }^{28}$. Powyższa mapa obrazuje jak bardzo złożony jest problem Hell Joseon, a także jego oddziaływanie na wszystkie etapy ludzkiego życia.

Z Hell Joseon związane są różnorodne nowe pojęcia i terminy, którymi Koreańczycy opisują zaistniałą, często trudną rzeczywistość. Jednym z nich jest „teoria klas łyżek” (ang. spoon class theory, kor. 수저론, sujoron), które wywodzi się z zachodniego powiedzenia „Urodził się ze srebrną łyżeczką w ustach" i definiuje nowe rodzaje hierarchii poprzez standard życia. Natomiast standard ten jest zdeterminowany przez majątek rodziców, co klasyfikuje poszczególne osoby do stałych grup ${ }^{29}$. Łyżki, a tym samym poziomy bogactwa, dzieli się na pięć różnych rodzajów, od łyżki diamentowej, przez złotą, srebrną, brązową i brudną. Osoby przypisane do grupy łyżek diamentowych, a właściwie to ich rodzice, posiadają roczny dochód w wysokości $300 \mathrm{mln}$ wonów ${ }^{30}$, aktywa powyżej 3 mld wonów i stanowią zaledwie 0,1\% koreańskiego społeczeństwa. Złote łyżki obejmują $1 \%$ populacji, a ich dochody wynoszą $200 \mathrm{mln}$ wonów rocznie, z kolei srebrne łyżki to 3\% Koreańczyków, których aktywa wynoszą powyżej miliarda wonów. Roczny dochód brązowych łyżek określany jest na poziomie $55 \mathrm{mln}$ wonów, a ta grupa stanowi 7,5\% społeczeństwa. Cała reszta mieszkańców Korei, czyli prawie 90\% ludności, określana jest mianem brązowych łyżek. Ich dochody wynoszą poniżej $20 \mathrm{mln}$ wonów, a aktywa poniżej 50 mln koreańskich wonów. Podsumowując jest to podział na osoby urodzone w bardzo bogatych, zamożnych, średniej klasy oraz ubogich rodzinach.

28 Se Woong Koo, op.cit.

29 Jun Lee, Spoon-Class Theory, 인하프레스 [Inhapress], http://www. inhapress.com/news/articleView.html?idxno=6463 [dostęp: 15.03.2019].

30 Jeden milion wonów jest równoznaczny z 850 USD. 
Tabela 1. Tabela zawierająca kategorie łyżek

\begin{tabular}{|l|l|l|}
\hline Diamentowe łyżki & $\begin{array}{l}\text { Aktywa: powyżej } 3 \mathrm{mld} \text { wonów } \\
\text { Dochód roczny: } 300 \mathrm{mln} \text { wonów }\end{array}$ & $0,1 \%$ - wyższa klasa \\
\hline Złote łyżki & $\begin{array}{l}\text { Aktywa: powyżej } 2 \mathrm{mld} \text { wonów } \\
\text { Dochód roczny: } 200 \mathrm{mln} \text { wonów }\end{array}$ & $1 \%$ - wyższa klasa \\
\hline Srebrne łyżki & $\begin{array}{l}\text { Aktywa: powyżej } 1 \mathrm{mld} \text { wonów } \\
\text { Dochód roczny: } 80 \mathrm{mln} \text { wonów }\end{array}$ & $3 \%$ - wyższa klasa \\
\hline Brązowe łyżki & $\begin{array}{l}\text { Aktywa: powyżej } 500 \mathrm{mln} \text { wonów } \\
\text { Dochód roczny: 55 mln wonów }\end{array}$ & $7,5 \%$ - wyższa klasa \\
\hline Brudne łyżki & $\begin{array}{l}\text { Aktywa: poniżej } 50 \text { mln wonów } \\
\text { Dochód roczny: poniżej 20 mln wonów }\end{array}$ & Reszta \\
\hline
\end{tabular}

Źródło: opracowanie własne na podstawie: Hyejin Kim, "Spoon Theory" and the Fall of a Populist Princess in Seoul, "The Journal of Asian Studies" 2017, vol. 4, nr. 76, s. 845.

Ta teoria jest nowym sformułowaniem, którego początki sięgają 2015 r., kiedy w Internecie pojawiło się określenie „złotej łyżki” w odniesieniu do młodej niedoświadczonej aktorki, której znany ojciec zapewnił szereg znaczących ról. Od tego czasu w mediach często pojawiały się nie tylko informacje o sławnych osobach, które skorzystały na posiadaniu zamożnych rodziców, ale także gry i memy dotyczące tego zjawiska, a nawet aplikacje pozwalające określić swój typ łyżki. Rodzaj łyżki zaczął determinować tożsamość osoby, do której przynależał, a łyżka z którą się przyszło na świat determinowała człowieka. Według tej klasyfikacji zaczęto mówić, że „jest się złotą łyżką”, a nie, że „otrzymał złotą łyżkę”. Teoria klas łyżek początkowo używana w zabawny i lekki sposób do plotkowania o gwiazdach, szybko przeniosła się na pozostałe pola społeczne, tym samym uderzając w istotne problemy. Dała ona wyraz coraz to większemu niezadowoleniu i niepokoju, że tylko bogactwo i wysoki status determinują życiowy sukces ${ }^{31}$. Z racji tego, że według tej teorii zmiana klasy jest tak trudna, a właściwie niemożli-

31 Hyejin Kim, "Spoon Theory" and the Fall of a Populist Princess in Seoul, „The Journal of Asian Studies” 2017, vol. 4, nr 76, s. 843-845. 
wa, pojawił się problem deprywacji, zwłaszcza wśród młodych osób. Jednostki rozpoznając ścisłą hierarchię, której nie mogą zmienić, porzucają nadzieję i chęci do poprawy swojej pozycji. Przepaść między bogatymi i biednymi jest właściwie nie do przeskoczenia i stale się powiększa, o czym świadczą ostatnie badania Koreańskiego Instytutu Zdrowia i Spraw Społecznych (KIHASA), według których tylko 2,9\% osobom urodzonym w biednych rodzinach udało się uniknąć ubóstwa. Taki pesymistyczny obraz przyszłości dla wielu młodych Koreańczyków staje się powodem, dla którego zaczynają być ospali, tracą poczucie sensu, a nawet ochoty do życia ${ }^{32}$. Student elitarnego Uniwersytetu Narodowego w Seulu w grudniu 2015 r. popełnił samobójstwo, ponieważ pomimo swoich wybitnych osiągnięć naukowych, brakowało mu wysokiego statusu i bogactwa, bez których nie miał szans na pomyślną przyszłość. W swojej notatce napisał: „To społeczeństwo sprawia, że cierpię. Wstydzę się... W tym społeczeństwie, które mówi o kolorze łyżek, myślałem, że mam »złoty płat czołowy«. Zdałem sobie jednak sprawę, że to, co decyduje o przeżyciu, nie jest kolorem płata czołowego, ale kolorem łyżki"33.

Jego słowa uświadamiają powagę sytuacji w jakim znajduje się koreańskie społeczeństwo. Teoria klas łyżek wyprowadza na światło dzienne „piekielną” rzeczywistość, gdzie dobrze urodzeni mają większe szanse i stają się coraz bardziej potężniejsi. Z kolei ubodzy nie mogą uciec przed trudami życia, a ich sytuacja jedynie się pogarsza. Co gorsza, ramy tego podziału są sztywno ustalone, dlatego ciężko jest

32 Jun Lee, op.cit.

33 Jo Min Ju, The Theory of Spoon: Choosing Life either Gold Spoon or Soil Spoon, 두드림 [Dudream], http://dudream.daegu.ac.kr/news/articleView.html?idxno=2971 [dostęp: 13.02.2019]. 
w jakikolwiek sposób jemu zaradzić, co tym bardziej przygnębia i frustruje Koreańczyków.

Z opisanego wyżej przygnębienia i rozgoryczenia, a także życiowej niestabilności wywodzi się kolejny termin używany przez Koreańczyków do opisywania rzeczywistości Hell Joseon. Jest nim sampo sedae bądź też 3-po sedae. W języku koreańskim sedae to generacja, sam oznacza liczbę trzy, a z kolei po tłumaczy się jako rezygnacja, poddanie, zaniechanie. W całości po przełożeniu neologizm ten jest tłumaczony jako "generacja, rezygnująca z trzech rzeczy”. To sformułowanie odnosi się do mieszkańców Korei, którzy z powodu trudnych warunków muszą zrezygnować z miłości, małżeństwa i posiadania dzieci. Wraz z upływem czasu zaczęły powstawać kolejne określenia, takie jak opo sedae (5-po), czyli generacja, która oprócz wymienionych wcześniej trzech rzeczy, rezygnuje także z pracy i posiadania własnego domu. Chilpo sedae (7-po) porzuca relacje międzyludzkie i nadzieję, a gupo sedae (9-po) rezygnuje ze zdrowia i wyglądu fizycznego. Co więcej, w ostatnim czasie na koreańskich blogach internetowych zaczęły pojawiać się kolejne terminy, tj. wanpo sedae oraz jeonpo sedae, oznaczające kolejno generację pełnej rezygnacji i generację porzucenia wszystkiego. Całość dobrze podsumowuje określenie $n$-po sedae, w którym przedrostek staje się liczbą nieokreśloną „n”, co jest równoznaczne z porzuceniem praktycznie całego życia ${ }^{34}$. Termin opisujący to rezygnujące społeczeństwo pojawił się pod koniec 2000 r. w wyniku trudności ekonomicznych, niestabilności w znalezieniu miejsc pracy i niskich wynagrodzeń, z którymi musieli i nadal muszą zmagać się zwłaszcza młodzi Koreańczycy. Kolejnymi powodami, dla których mieszkańcy Korei zmuszeni są rezygnować

34 Youna Kim (red.), Routledge Handbook of Korean Culture and Society, New York 2017, s. 127-128. 
z niektórych aspektów życia, są z pewnością kryzys bezrobocia, szybka inflacja, gwałtownie rosnące ceny mieszkań oraz presje społeczne. Przykładowo, w 2016 r. przybliżona cena wydatków weselnych na ślub „średniej klasy” wynosiła 274 mln koreańskich wonów (ok. 230 tys. USD). W porównaniu do 2015 r., wzrosła ona aż o 15,2\%, nic więc dziwnego, że coraz mniej młodych osób decyduje się na małżeństwo, a ich liczba w Korei utrzymuje się na drastycznie niskim poziomie $^{35}$. Sytuacja wygląda podobnie w przypadku kosztów mieszkań czy wychowania i edukacji dzieci, co w połączeniu z niestabilnością ekonomiczną oraz możliwościami uzależnionymi od statusu społecznego powoduje brak sił i rezygnację. Życie w Korei stało się tym samym walką o przetrwanie, wobec której wiele młodych Koreańczyków jest bezsilna i się poddaje. Nie bez powodu, ale właśnie na bazie takich odczuć i doświadczeń nazwano Koreę Południową mianem Hell Joseon $^{36}$. Dobrze podsumowuje to Jang Kang Myung, autor głośnej książki Because I Hate Korea (Ponieważ nienawidze Korei), który w jednym z wywiadów stwierdził: „[Hell Joseon - przyp. R.Z.] jest refleksją młodych Koreańczyków, którzy twierdzą, że ich kraj nie jest krajem możliwości, ale raczej społeczeństwem frustracji. Nie przemawia już do nich więcej, kiedy starsze pokolenie każe im »bardziej się starać« czy »wkładać więcej wysiłku«. Nie słuchają, uważając że »i tak się nie uda«. Zostali zniechęceni rzeczywistością i znieważeni przez społeczeństwo, więc zdają się chcieć odpłacić społeczeństwu za tę obrazę"37.

\footnotetext{
35 Jun Lee, op.cit.

36 Sojeong Park, op.cit., s. 5-6.

37 Han Dae Cho, Author expounds on 'Hell Joseon', „Korea JoongAng Daily”. 11.10.2015, http://koreajoongangdaily.joins.com/news/article/article.aspx?aid=3010170 [dostęp: 19.02.2019].
} 


\section{Zakończenie}

Republika Korei, choć małe powierzchniowo, to gospodarczo jest to jedno z najlepiej rozwiniętych państw, w którym technologia stoi na najwyższym poziomie. Jednak pomimo technologicznego zaawansowania, w społeczeństwie koreańskim można zauważyć wiele pozostałości z przeszłości, a przywiązanie do tradycji i historii jest nadal bardzo silne. Nowoczesne i rozwinięte państwo, które szanuje tradycję wydaje się być państwem idealnym. Jednak Korei Południowej daleko od ideału. Okazuje się bowiem, że historyczne przywiązanie do hierarchii nie tylko podzieliło społeczeństwo na klasy, ale także pogłębiło różnice między nimi. Spowodowało to rozłam na mało liczną grupę osób bogatych i uprzywilejowanych oraz na resztę społeczeństwa, która musi ciężko pracować na jakiekolwiek udogodnienia, a i tak często jest dyskryminowana i nie ma szans w konkurencji o sukces z tymi wyżej postawionymi. Ta sytuacja doprowadziła z kolei do rosnącego niezadowolenia z jakości życia i własnego kraju pośród wielu Koreańczyków. Warto spojrzeć na wskaźnik szczęścia, w którym Korea Południowa spośród 156 państw zajęła w 2020 r. dopiero 61 miejsce, podczas gdy w dwa lata wcześniej była to pozycja $57^{38}$. Również wysoki od paru lat poziom samobójstw, który wcale nie sprawia wrażenia, by się zmniejszał, wręcz przeciwnie, co rusz słychać o nowych przypadkach zamachów na własne życia, nawet pośród wydawałoby się uprzywilejowanych celebrytów. Z niezadowolenia i przygnębienia swoją sytuacją,

38 J.F. Helliwell, R. Layard, J.D. Sachs, World Happiness Report 2020, s. 25 . 
pośród młodych Koreańczyków rozprzestrzeniło się nowe pojęcie - Hell Joseon, porównujące współczesną Koreę do zacofanego, zhierarchizowanego, a co więcej piekielnego dawnego państwa koreańskiego, zwanego Joseon. Niektórzy nawet uważają, że oba składniki tego określenia znaczą dokładnie to samo, a połączone ze sobą tylko intensyfikują porównanie. Ten nowy zwrot, który zakorzenił się już w koreańskim języku, odnosi się do wielu problemów, z którym zmaga się społeczeństwo Korei Południowej, w tym młodzi ludzie.

Co wydaje się równie istotne to fakt, iż zagadnienie Hell Joseon jest praktycznie zupełnie nie poruszone przez zachodnich badaczy i naukowców, niewspominając o zupełnym braku materiałów w języku polskim. Jako że jest to termin stosunkowo nowy, nie został jeszcze przeanalizowany przez międzynarodowe środowisko naukowe, a wszelkie prace powiązane $\mathrm{z}$ tym zagadnieniem pozostają sporządzane wyłącznie przez badaczy koreańskich. Nie uzasadniono jednak do tej pory czy zjawisko Hell Joseon jest autentyczne, czy może figuruje jedynie jako neologizm, którym posługują się młodzi ludzie, by móc użalać się nad sobą. Jako że jest to problem bardzo złożony, nie ma również żadnych danych dotyczących całego zjawiska, można jedynie spoglądać na statystyki opisujące kwestie zaliczające się do ogólnej problematyki i próbować wyciągać wnioski. Nie ma wątpliwości, że Hell Joseon, jako niezwykle szerokie zjawisko, obejmujące praktycznie wszystkie grupy społeczne, wymaga badań i analiz w przyszłości. Dalsze prace powinny objąć badaniem nie tylko różne grupy dotknięte tym problemem, takie jak osoby młodsze czy starsze, ale także zbadać jak to sformułowanie jest odbierane przez samo koreańskie społeczeństwo. Być może, że dzięki dogłębnej analizie będzie 
można wypracować autentyczny obraz Hell Joseon, a także znaleźć rozwiązanie, które pozwoli zminimalizować jego skutki, natomiast Korea przestanie być dla własnych obywateli piekielną ojczyzną.

\section{Bibliografia}

Cho Han Dae, Author expounds on 'Hell Joseon', „Korea JoongAng Daily”, 11.10.2015, http://koreajoongangdaily. joins.com/news/article/article.aspx?aid=3010170.

Chung Sungeun, The Rise of Self-deprecating Terms Such as "Hell Chosun" and "Dirt Spoon" among the Young Generations in Korea, Korea Economic Institute of America, http:// keia.org/rise-self-deprecating-terms-such-\%E2\%80\%9Chell-chosun\%E2\%80\%9D-and-\%E2\%80\%9Cdirt-spoon\%E2\%80\%9D-among-young-generations-korea.

Helliwell J.F., Layard R., Sachs J.D., World Happiness Report 2020.

Iwicka R., Czy kultura koreańska zatopiła Sewol?, [w:] Kultury Wschodu w świecie procesów globalizacyjnych, red. P. Mróz, M. Ruchel, A.I. Wójcik, Kraków 2015.

Ju Jo Min, The Theory of Spoon: Choosing Life either Gold Spoon or Soil Spoon, 두드림 [Dudream], http://dudream. daegu.ac.kr/news/articleView.html?idxno=2971.

Kim Hyejin, "Spoon Theory" and the Fall of a Populist Princess in Seoul, „The Journal of Asian Studies” 2017, vol. 4, nr 76.

Kim Jiyoon, South Korean Youth in Crisis Implications for Political Leadership, „Georgetown Journal of Asian Affairs" 2016.

Kim Youngmi, Hell Joseon: Polarization and Social Conten- 
tion in a Neo-liberal Age, [w:] Korea's Quest for Economic Democratization, red. Youngmi Kim, London 2018. Koo Se Woong, Korea, Thy Name is Hell Joseon, Korea Exposé, 22.09.2015, http://www.koreaexpose.com/korea-thy-name-is-hell-joseon/\#.

Lee Jun, Spoon-Class Theory, 인하프레스 [Inhapress], http:// www.inhapress.com/news/articleView.html?idxno=6463. Lee Minyoung, "Escape from Hell-Joseon": A Study of Korean Long-term Travelers in India, „Korean Anthropology Review" 2019, nr. 3.

Lee Yong Ik, Korean Society depicted in its Folklore - Goryeo and Joseon period, World History at KMLA, https:// www.zum.de/whkmla/sp/0607/yongik/Yongiklee.html\#Joseon.

Levi N., The Impact of Confucianism in South Korea and Japan, „Acta Asiatica Varsoviensia” 2013, nr 26.

Min Ang Hwee, S. Korea's young lament inequality in their society, „Thestraitstimes”, 7.01.2018, https://www.straitstimes.com/asia/s-koreas-young-lament-inequality-in-their-society.

Park Eun Chae, Selling Successful Bodies: the construction of female beauty ideals on the Websites of Korean cosmetic surgery clinics, MA (60 EC) Asian Studies History, Arts \& Culture of Asia, 2018.

Park No-ja, "Hell Joseon" - a country where sleepless toil brings no mobility, „Hankyoreh”, 6.01.2015, http://english.hani. co.kr/arti/english_edition/e_national/711631.html.

Park Sojeong, Misogyny in Hell-Joseon: An Intersectional Approach to the Misogyny of South Korean Society, The Asian Conference on Cultural Studies 2017 Official Conference Proceedings, Seoul National University, Korea Południowa. 
Rurarz J., Historia Korei, Warszawa 2009.

Savada A.M., Shaw W. (red.), South Korea: A Country Study, Washington 1990.

Seth M.J., A History of Korea: From Antiquity to the Present, Lanham 2010.

Shin Kwang Yeon, Class and Income Inequality in Korea, „Korea Journal” 2004.

Sorensen C.W., Baker D. (red.), Political Uses of Confucianism in North Korea, "The Journal of Korean Studies” 2011, vol. 1, nr 16.

Śleziak T., The Role of Confucianism in Contemporary South Korean Society, „Rocznik Orientalistyczny” 2013, t. 1, nr 66.

Woolf D.R. (red.), A Global Encyclopedia of Historical Writing, New York-London 1998.

Youna Kim (red.), Routledge Handbook of Korean Culture and Society, New York 2017.

\begin{abstract}
Abstrakt
Hell Joseon jest niedawno powstałym sformułowaniem określającym obecną sytuację społeczną w Republice Korei, które szybko zakorzeniło się w języku koreańskim. Celem pracy jest przybliżenie tego neologizmu, a także powiązanych z nim zjawisk, ich możliwych przyczyn oraz implikacji. Artykuł prezentuje również obraz dawnego państwa Joseon i wprowadzonego wówczas neokonfucjanizmu oraz ich wpływ na współczesny wygląd koreańskiego społeczeństwa, przedstawia także argumenty przemawiające za tym, iż zagadnienie Hell Joseon nie jest wyłącznie powszechnym w języku zwrotem, ale autentycznym problemem. Ze względu na to, że jest to stosunkowo nowe zagadnienie, niepodjęte przez zagraniczne ani polskie środowisko naukowe, praca jest nie tylko jedną z pierwszych w tym temacie na polskim rynku, ale jest również zachętą do podjęcia dalszych badań w tym obszarze.
\end{abstract}


Słowa kluczowe: Korea, społeczeństwo, Hell Joseon, nierówności społeczne, podział na klasy, neokonfucjanizm

\begin{abstract}
Hell Joseon is a recent phrase that describes the current social situation in the Republic of Korea, which has quickly taken root in the Korean language. The aim of the work is to bring closer this neologism, as well as the related phenomena, their possible causes and implications. The article also presents a picture of the former Joseon state and the neo-confucianism introduced at that time and its impact on the contemporary appearance of Korean society, as well as the arguments that the Hell Joseon issue is not only a common phrase in language but an authentic problem. As it is a relatively new issue, not addressed by the foreign or Polish scientific community, the work is not only one of the first in Poland on this topic, but it is also an incentive to undertake further research in this area.
\end{abstract}

Keywords: Korea, society, Hell Joseon, social inequalities, class system, neo-confucianism 


\section{Aleksandra Kobylańska}

Szkoła Główna Gospodarstwa Wiejskiego w Warszawie

Uczelnia Społeczno-Medyczna w Warszawie

ORCID ID: https://orcid.org/0000-0003-1544-3528

\section{Wychowanie do wartości dzieci i młodzieży w Japonii}

"Gwóźdź, który wystaje, prosi się o młotek” (przysłowie japońskie)

\section{Wprowadzenie}

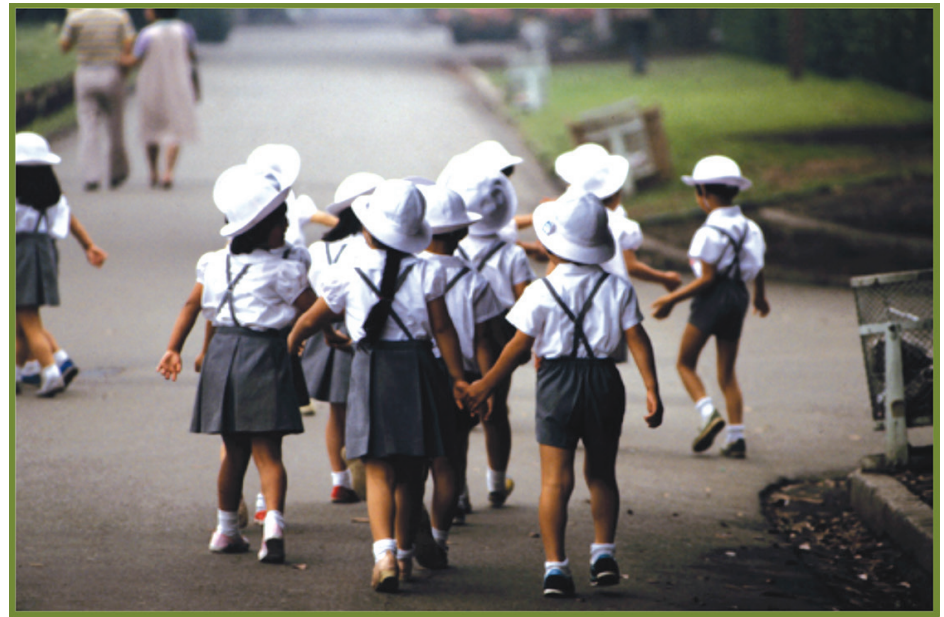

Źródło: Wychowanie i edukacja w Japonii, http://czaszdziecmi. $\mathrm{pl} /$ js/kcfinder/upload/images/Japanese-children.jpg [dostęp: 14.12.2020]. 
Kultura Japonii (jap. 日本の文化 Nihon no bunka) ewoluowała na przestrzeni tysiącleci, od czasów prehistorycznej kultury okresu Jōmon do czasów dzisiejszej hybrydowej kultury z silnymi wpływami świata europejskiego i amerykańskiego.

Które wartości sq najważniejsze? Co chcielibyśmy przekazać dzieciom, by wyrosty na szczęśliwych, „dobrych i porzadnych" ludzi? System wartości człowieka budowany jest przez rodziców, rodzinę, nauczycieli, kolegów czy środowisko. Głównym przekaźnikiem wartości jest wychowanie, rozumiane jako przygotowanie młodego człowieka do życia oraz ukształtowanie jego osobowości w warunkach konkretnej rzeczywistości społecznej i cywilizacyjnej.

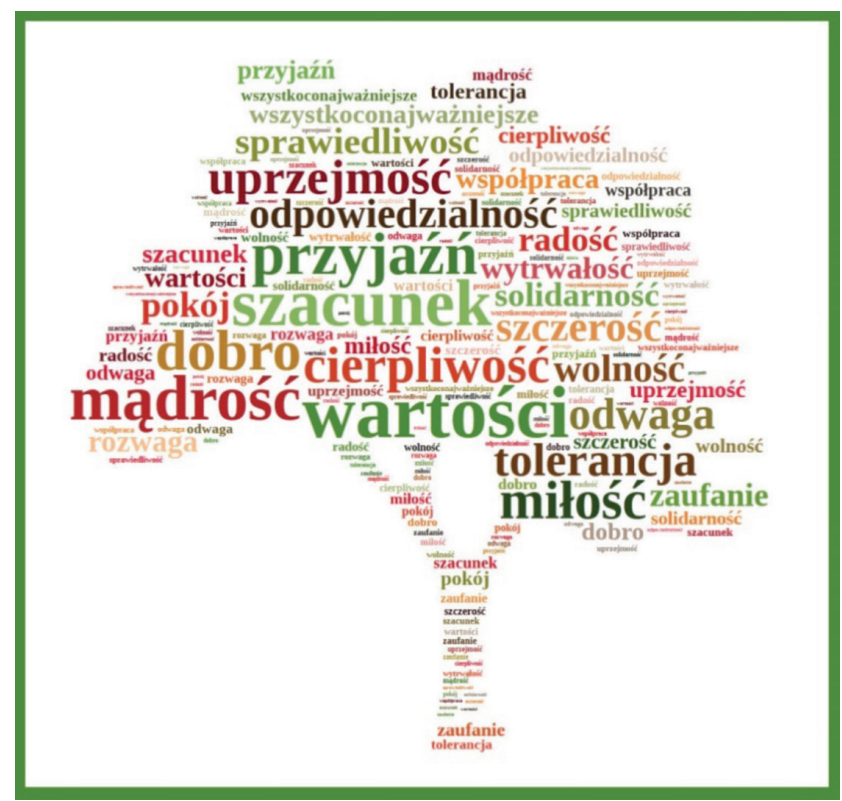

Źródło: Wartości, https://zslatowicz.pl/wp-content/uploads/ 2019/10/wart.jpg [dostęp: 10.12.2020]. 
Wychowanie to wprowadzenie dzieci i młodzież w kulturę własnego narodu i społeczeństwa, kulturę mowy i języka ojczystego, a także stosowne oddziaływanie rodziców, wychowawców i nauczycieli na dzieci i młodzież. Jednym z celów wychowania jest stworzenie systemu wartości, który stanowi fundament życia człowieka. Każda osoba z dzieciństwa wynosi bagaż składający się z przekazanych przez rodziców wartości, wzorców zachowań, nawyków, przekonań, poglądów, norm społecznych czy zapatrywań na świat. Tak zbudowany system wartości buduje osobowość i kształtuje życie człowieka. Najważniejszym sposobem trwałego przekazania dzieciom wartości jest własny przykład i zgodność między deklaracjami słownymi a życiem. Dziecko uczy się w głównej mierze przez naśladowanie. Obserwuje postępowanie mamy i taty, słucha co mówią, patrzy jak reagują. Dlatego na dorosłych spoczywa odpowiedzialność za przekazywane dzieciom wartości i wzorce postępowania w życiu.

A jak to jest w Kraju Kwitnacej Wiśni? ${ }^{1}$ „Młode japońskie dziewczęta, zanim przeistoczą się w matki lub posłuszne pracownice korporacji, szaleją na skuterach, zakładają wymyślne buty na koturnach i masowo utleniają włosy. Używają form gramatycznych dotąd zastrzeżonych dla mężczyzn i bardzo ostentacyjnie obnoszą się ze swoją niezależnością. (...) Nie jedzą mięsa i angażują się politycznie, co nie jest najlepiej odbierane w pokoleniu ich dziadków. Swobodnie traktują związki. Wiele z nich w ogóle nie ma planów matrymonialnych"2.

Japonia to kraj, który jest powszechnie i dość stereotypowo kojarzony z samurajami, zimnym sake, bezwzględną Yakuzą, gejszami, mangą, anime oraz z kobietami ubra-

1 K. Sak, Wartości w naszym życiu, http://zslatowicz.pl/bez-kategorii/wartosci-w-naszym-zyciu/ [dostęp: 10.12.2020].

2 R. Korzycki, Emancypantki, „Polityka” 2006, nr 15 (2550), s. 53. 
nymi w kimono, wiecznie zapracowanymi biznesmenami w ciemnych garniturach, z przepracowaniem, jak również z grzecznością, czystością, wysoko rozwiniętą technologią i bezpieczeństwem. Mniej uwagi poświęca się różnorodnym przejawom współczesnego życia Japończyków, a zwłaszcza zmianom, które w Japonii zachodzą ${ }^{3}$. Wartościowe w kulturze Japonii jest nie tylko to, co unikalne i typowo japońskie.

W artykule podjęta zostanie próba przybliżenia czytelnikowi interesującego zjawiska kulturowego kreowanego przez japońskie dzieci i młodzież, ze szczególnym uwzględnieniem wartości. Celem artykułu jest próba wykazania, że jednym z najistotniejszych czynników, które wpływają na wychowanie do wartości są wartości narodowe, oparte na systemie filozoficzno-religijnym, eksponującym rolę rodziny, wartości grupy, zasady egalitaryzmu i konieczność stałego doskonalenia się. Podkreślone zostaną cechy Japończyków predysponujące ich do zbudowania wysoce sprawnej organizacji, grupy, przedsiębiorczości, a także wykazane zostanie znaczenie rodziny wychowującej dzieci, formującej charakter jednostki, będącej podstawą spójności społeczeństwa, siły grupy. Przytoczona zostanie ogólna charakterystyka szkolnictwa, spełniającego nie tylko funkcję nauczania, ale przede wszystkim wychowania. Japonia jest krajem o najwyższym poziomie społecznego zaufania. Trudności codziennej egzystencji: długotrwała izolacja od świata, blisko stutrzydziestomilionowy naród (zajmujący 10. miejsce na świecie), wulkaniczne wyspy, sejsmiczny teren, tajfuny, fale pływowe, wiosenne powodzie, burze śnieżne, brak ziemi, teren górzysty, brak surowców zadecydowały, że społeczeństwo japońskie jest bardziej zwarte od ludności

3 M. Cylkowska-Nowak, A. Butkiewicz, Street Fashion of Japan jako próba konstruowania tożsamości młodzieży japońskiej, „Przegląd Pedagogiczny" 2009, nr 1 (11), s. 59. 
zamieszkującej inne kraje, tworząc jedno z najbardziej zwartych społeczeństw na świecie ${ }^{4}$. „Podczas gdy Europejczycy kładą nacisk na indywidualne wyrażanie siebie i oryginalność, Japończycy wierni są całkowicie odwrotnemu procesowi. Społeczność tworzą jednostki podobne do siebie, nie różniące się w zasadniczy sposób, dążące do upodobnienia się do reszty. To sprawia, że grupa i społeczność jest w stanie działać sprawnie i porozumieć się bez trudności. Inność jest uważana za coś nie pożądanego” . „Obawa przed wyróżnieniem się z grupy jest ogromna nawet wśród dorosłych. Raczej nie wypada wyróżniać się ponad grupę zdolnościami czy prywatnością z uwagi na przyjętą tu zasadę odpowiedzialności grupowej, tak za sukcesy jak i za porażki”6.

Japończycy wypracowali własne zasady postępowania. Przyjęte w Japonii systemy filozoficzne, religie i tradycje kształtują kulturę. Japoński światopogląd religijny, szintoizm oraz przejęty z Chin (powstały w V w. p.n.e.) system filozoficzno-religijny konfucjanizmu oraz buddyzm zen wywierają zdecydowane piętno na wszystkie sfery życia.

Systemy wartości przyjęte w Japonii nakładają na ludzi obowiązek samodoskonalenia się - filozofia Kaizen (postrzega optymalizację procesów jako wdrażanie małych, ale cyklicznych zmian, czynny udział pracowników w procesie optymalizacji itp.). Szerzą stoicyzm, głoszą pochwałę cierpliwości i umiaru. Ujmują człowieka jedynie jako element przyrody. Nie stawiają człowieka w centrum świata, ale próbują znaleźć dla niego miejsce, ukształtować go. Stąd wrodzona skromność jednostki i pęd do wiedzy, poszanowanie autory-

4 J. Figuła, Wartości narodowe a konkurencyjność Japonii, „Ekonomia - Wroclaw Economic Review" 2014, nr 20/1, s. 56-57.

5 K. Demusiak, Ludy starożytnej Japonii, Warszawa 2007.

6 K. Czerkawski, Komu zostaje zimny ryż, „Życie”, 18-19.09.1999. 
tetu. Głoszone jest hasło, że „nie ma wolności bez autorytetu, bez powinności i zobowiązań"7. W Japonii człowiek może zdobyć autorytet poprzez pracę i przynależność do grupy.

\section{Japońskie dzieci}

Mali Japończycy żegnają się z dzieciństwem, gdy kończą sześć lat i idą do szkoły. Samodzielnie. Kochająca mama może im tylko pomachać przez okno, bo odprowadzanie dzieci do szkoły jest zabronione. Japończycy przedkładają cele grupy nad celami indywidualnymi oraz wysiłki na rzecz grupy nad wysiłkami mającymi za cel powodzenie jednostki. Dobro ogółu jest ważniejsze od dobra jednostki. Z tego przekonania wynika poczucie zbiorowej odpowiedzialności za zachowania niesfornych „szczeniąt”. Częstym widokiem są dorośli dający reprymendę nieswojemu dziecku za niewłaściwe zachowanie i pociągający ich do natychmiastowych konsekwencji. Dochodzi nawet do sytuacji, w których spacerujący (np. będący na wagarach) w trakcie trwania lekcji młodzian, może zostać siłą odprowadzony przez policjanta pod bramę właściwiej szkoły. W grupie siła. Japońskie dzieci są wychowywane do działania w grupie, a następnie do działania w społeczeństwie. Dzieci wychowują się i bawią. Dzieci i młodzież spędzają znaczną część czasu w towarzystwie swoich rówieśników - w ciągu tygodnia jest to czas poświęcony szkole i zajęciom dodatkowym, takim jak zajęcia w klubach szkolnych (związanych z hobby lub tradycyjnymi sztukami japońskimi) oraz czas wolny spędzony na wspólnych zakupach, wyjściach do kina, itp. W Japonii w żadnym wypadku nie ma mowy o przyjaźni

7 T.M. Suzuki, $A$ History of Japanese Economic Thought, London-New York 1989, s. 14. 
czy partnerstwie w relacjach rodzic - dziecko czy nauczyciel - dziecko. Rodzicom i nauczycielom należy się szacunek i posłuszeństwo. Szacunek należy się nawet starszym uczniom. Umiejętność odpowiedniego okazywania szacunku innym jest przez Japończyków wysoce ceniona i wykorzystywana przez całe życie ${ }^{8}$.

Japońskie dzieci mają jedne wspólne urodziny. Dzieci, które w danym roku kończą trzy, pięć i siedem lat, obchodzą urodziny razem tego samego dnia - 15 listopada. Święto nazywa się Shichi-go-san, czyli 3-5-7. Według tradycyjnych wierzeń dziecko, ukończywszy siedem lat, staje się członkiem wspólnoty rodowej. Dopiero wtedy mali Japończycy mają prawo ubierać się jak dorośli i odwiedzać świątynię 9 .

Wychowanie w duchu Dalekiego Wschodu to także przyzwolenie na stosowanie kar cielesnych, zwłaszcza po to, by zmotywować dziecko do nauki.

Japońskie dzieci wychowuje się w oparciu o wrażliwość. Większość rodzin japońskich rozumie, że wychowywanie dzieci powinno być pełne uczuć i troski. Krzyki i poważne oskarżenia są czymś, na co patrzy się nieprzychylnym okiem. To, czego rodzice spodziewają się od swoich dzieci to, że nauczą się one stawiać światu czoło, szanując wrażliwość innych $^{10}$.

8 Wychowanie i edukacja w Japonii, http://marzeojaponii.blogspot. com/2014/12/wychowanie-i-edukacja-w-japonii-cz-1.html [dostęp: 14.12.2020].

9 J. Dominia, Chińczycy wychowuja bez pieluch, Skandynawowie bez stresu, a Francuzi zostawiaja niemowlaka z niania i jada na urlop, https:// www.wysokieobcasy.pl/wysokie-obcasy/56,176062,21847315,japonia-czylinie-jestes-najwazniejszy,,3.html?disableRedirects=true [dostęp: 14.12.2020].

10 Japońskie dzieci - dlaczego sq postuszne i nie dostają napadów wściekłości?, https://pieknoumyslu.com/japonskie-dzieci-dlaczego-posluszne/ [dostęp: 14.12.2020]. 


\section{Współczesna szkoła japońska i jej zadania}

Szkoła japońska nie tylko uczy, ale przede wszystkim wychowuje, „(...) jest miejscem w którym dzieci uczą się żyć w społeczności i przestrzegać surowych reguł współdziałania. Uczniowie uczą się dyscypliny, porządku, hierarchii relacji”"11. Szkoła kształtuje postawę patriotyczną, zaszczepiając już w małych dzieciach poczucie dumy narodowej, poprzez poznanie historii i tradycji japońskiej. Po II wojnie światowej rozwój materialny kraju wzbogacił społeczeństwo, powodując upadek morale i ducha wspólnoty. Rząd Shinzo $A b e^{12}$ - zaniepokojony amerykanizacją kultury japońskiej, odwracaniem się młodego pokolenia od swojej tradycji, brakiem szacunku dla starszych - zmienił Konstytucję Japonii napisaną pod dyktando Amerykanów, wprowadzając „kształcenie w duchu miłości ojczyzny, respektowania tradycji, kultury, a także innych narodów"13. W 2006 r. nakazano krzewienie dumy narodowej poprzez „nauczanie w szkołach miłości do kraju i rozwijanie poczucia obywatelskiego" ${ }^{14}$. W japońskich szkołach śpiewany jest hymn w trakcie ceremonii szkolnych, a na maszt wciągana jest narodowa flaga.

11 J. Figuła, Wartości..., op.cit., s. 59.

12 Shinzō Abe (jap. 安倍 晋三 Abe Shinzō, ur. 21 września 1954 r. w Tokio) - japoński polityk, premier Japonii od 26 września 2006 r. do 26 września 2007 r. oraz ponownie od 26 grudnia 2012 r. do 16 września 2020 r. Przewodniczący Partii Liberalno-Demokratycznej od 26 września 2012 r. do 14 września 2020 r. Członek Nippon Kaigi; Shinzō Abe, Wikipedia, https://pl.wikipedia.org/wiki/Shinz\%C5\%8D_Abe [dostęp: 14.12.2020].

13 Japan school to teach patriotism, „BBC News”, 18.05.2007.

14 Japonia. Parlament przyjąt ustawę w sprawie nauczania patriotyzmu w szkołach, „PAP”, 15.12.2006. 
Szkoła kształtuje postawy uczniów: wrażliwości na drugą osobę, troski o innych, odpowiedzialności i organizacji. Dzieci od najmłodszych lat uczą się przynależeć do wspólnoty, pracować na jej rzecz. Na starszych uczniach spoczywa obowiązek odprowadzenia młodszych kolegów do szkoły. Takie relacje od najmłodszych lat rozwijają u dzieci odpowiedzialność za drugą osobę, punktualności, respektu.

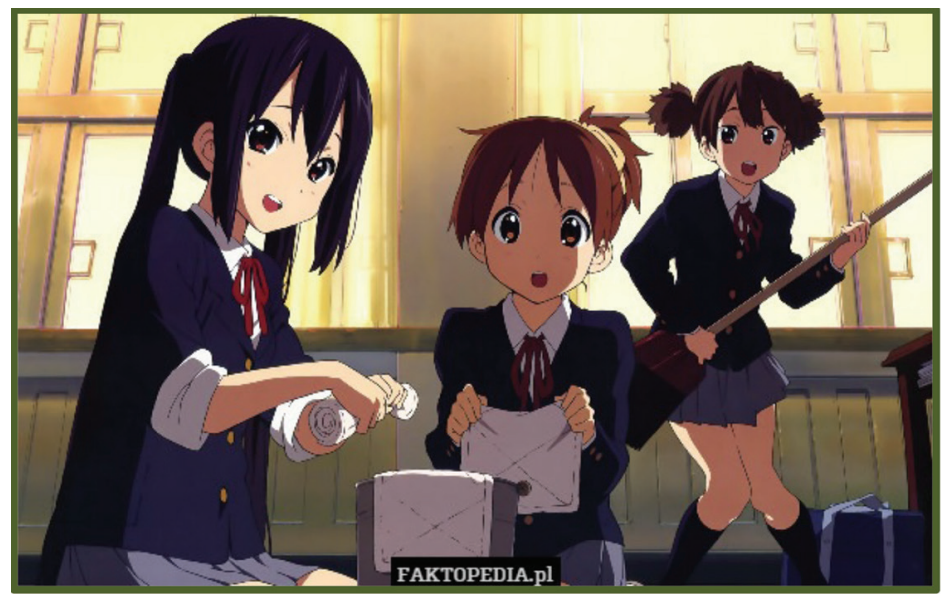

Źródło: Faktopedia.pl, https://faktopedia.pl/501880 [dostęp: 14.12.2020].

Japońskie szkoły nie zatrudniają sprzątaczek. Nauczyciele i uczniowie sami sprzątają wszystkie pomieszczenia łącznie z toaletami, pielęgnują trawniki i klomby, bo - jak wierzą Japończycy - pozwala to zacieśnić więzy wśród uczniów i uczyć ich odpowiedzialności. W wielu szkołach co pewien czas zmieniany jest skład uczniów w poszczególnych klasach, przynależność dzieci do poszczególnych klas po to, aby dzieci nabyły umiejętności współpracy z nowymi kolegami, która w dorosłym wieku zaowocuje umiejętnością nawiązywania 
lepszych relacji pomiędzy ludźmi. W szkole obowiązują mundurki będące świadectwem egalitaryzmu i przynależności do grupy $^{15}$.

Szkoła kształtuje u dzieci kulturę artystyczną i sportową. Rozkład dnia japońskiego dziecka jest rozpisany co do minuty. Nawet dwulatki chodzą regularnie na zajęcia rozwijające ich talenty, uczą się angielskiego, śpiewu, rysunków. Znakomita większość uczniów pobiera lekcje gry na pianinie. Stwierdzono, że gra na pianinie wzmacnia dyscyplinę i cechy organizacyjne, pobudzając procesy myślowe, podnosząc znacząco poziom kultury. Po lekcjach dzieci uczestniczą w „klubach", np. sportowych, humanistycznych. Zajęcia w klubach są obowiązkowe ${ }^{16}$.

Charakter Japończyków jest podziwiany na całym świecie. Można było ich zobaczyć w obliczu ogromnych tragedii, które znosili ze stoickim spokojem. Starają się oni nie tracić kontroli i utrzymywać zdrowy rozsądek w każdej sytuacji. Wyróżniają się także wielkim szacunkiem jaki okazują innym oraz dużą etyką pracy. Nie tylko osoby dorosłe, ale również japońskie dzieci bardzo różnią się od tego, do czego przyzwyczaił zachodni świat. Od bardzo wczesnego wieku japońskie dzieci są znane z łagodnego charakteru. Nie wpadają w złość i nie tracą nad sobą kontroli ${ }^{17}$.

\section{Współczesne wartości młodzieży japońskiej}

Nowe, demokratyczne państwo japońskie, powstałe po II wojnie światowej, uczyniło równość centralną wartością

15 J. Figuła, Wartości..., op.cit., s. 60.

16 Ibidem.

17 Japońskie dzieci..., op.cit. 
społeczną. System edukacji w tym kraju przebył bezsprzecznie długą i trudną drogę „postępująco-przystosowawczej ewolucji”, w toku której kształcenie dostępne w przeszłości tylko dla elit stało się egalitarne i powinno zapewniać równe możliwości edukacyjne wszystkim dzieciom. Uczniowie japońscy osiągają wysokie wyniki w międzynarodowych pomiarach wiedzy, a wysoki poziom szkolnictwa uważany jest za podstawę sukcesów ekonomicznych Japonii. Krajem tym wstrząsnęło kilka tragicznych zdarzeń, które skłoniły Japończyków do zadania sobie fundamentalnych pytań o narodowe wartości, życiowe cele każdego obywatela, a także o cele socjalizacji i edukacji ${ }^{18}$.

Dla Japończyków pochodzenie danego człowieka jest bardzo ważne, ponieważ w świadczy o jego wartości. Dzięki postulatom obrońców tradycyjnych wartości Japończycy zrozumieli, że nie można całego narodu przestawić na zupełnie nowe tory myślenia i działania, należy jedynie umiarkowanie czerpać ze wzorców państw zachodnich.

Japończycy tworzą modę równościową, która zrywa $\mathrm{z}$ tradycyjnym pojmowaniem płci. Biorące udział w cosplayowych konwentach dziewczęta mogą przebierać się za mężczyzn i odwrotnie, co jednak nie musi mieć żadnego związku z tożsamością płciową czy seksualnością. Wręcz przeciwnie - jest odgrywaniem kolejnej roli, oprócz tej narzucanej przez społeczeństwo. Człowiek na co dzień pracujący w korporacji i ubierający się w mundurek, tutaj może „zaszaleć” i pokazać się z zupełnie innej, kreatywnej strony. To, co w firmie uchodzi za ekstrawagancję i niedopasowanie do otoczenia,

18 M. Cylkowska-Nowak, Równość możliwości w edukacji japońskiej - kontynuacja i zmiana, „Teraźniejszość - Człowiek - Edukacja” 2009, nr 1 (45), s. 55, 61-62. 
na ulicach Harajuku pozwala wyrazić swoją indywidualność i niepowtarzalność ${ }^{19}$.

Głównymi narodowymi wartościami Japonii, które kształtują jej konkurencyjność, są religia szintoizmu oraz filozoficzno-religijne systemy konfucjanizmu i buddyzmu zen. Postawę poświęcenia, dyscypliny i zaangażowania rodziny wykształcają już u dzieci.

Nowoczesna Japonia przynosi wiele niepewności, które towarzyszą obywatelom od najmłodszych lat. W szkołach trzeba się uczyć ponad miarę, ponieważ konkurencja czyha na najmniejszy błąd. Studia wypada skończyć, żeby wypaść lepiej przed pracodawcą, ale i tak nie ma co liczyć po nich na pracę, która zapewni dalszy rozwój. Uczelnie pełne są młodych ludzi czekających na zakończenie nauki. Targi pracy pękają w szwach, przyciągają jednak zuniformizowane rzesze ludzi-klonów, którzy wiedzą, że manifestowanie indywidualności przyciągnie kłopoty, a nie dobrego szefa ${ }^{20}$.

Przynależność do grupy ma priorytetowy charakter. Obca jest im niezależność i wiara w siebie, dlatego postępują zgodnie z tym, co nakazuje grupa. Zjawisko to określane jest mianem "grupizmu”. „W grupie jednostka jest niewidoczna i anonimowa. Nie ponosi odpowiedzialności za czyny usankcjonowane przez grupę. Grupa wyznacza wartości, którymi muszą się kierować jej członkowie. O ile w kulturze zachodniej człowiek odpowiada za swoje czyny przed własnym sumieniem, o tyle w Japonii - przed grupą. Najważniejsze jest zachowanie twarzy w stosunku do grupy, gdyż jej dobro jako

19 M. Mrowiec, Inspiracje popkultura w modzie japońskiej od lat siedemdziesiątych XX wieku. Kawaii na przykładzie japońskiej mody ulicznej, [w:] 50 twarzy popkultury, red. K. Olkusz, Kraków 2017, s. 264.

20 R. Tomański, Jacy sq młodzi Japończycy? "Rzeczpospolita”, 22.04.2015, https://www.rp.pl/artykul/1195650-Jacy-sa-mlodzi-Japonczycy-.html [dostęp: 15.12.2020]. 
całości jest ważniejsze od dobra jednostki. To grupa decyduje o tym, czy działanie jednostkowe jest dobre, czy nie, a członek grupy działa tak by zyskać jej przychylność"21.

Młodzi ludzie stawiają sobie różnorodne i ważne dla nich pytania - kim jestem?; jaki jestem?; dlaczego taki jestem?; w jaki sposób zachowuję się w różnych okolicznościach?; jaki styl życia preferuję?; co lubię czytać?; jak się ubieram?; z jakimi poglądami, ideami, wartościami identyfikuję się?; w gronie jakich ludzi lubię przebywać? W kontekście tych pytań młodzież podejmuje liczne próby określenia własnej tożsamości. Według czasopisma „Rzeczpospolita”: „Japoński nastolatek na pierwszy rzut oka nie wypada w sondażu diametralnie inaczej od swoich rówieśników z zagranicy. Tak jak oni korzysta nałogowo z Twittera (63\%. studentów, 50\% licealistów) i Instagramu (połowa ankietowanych Japonek) i robi sobie często zdjęcia z rąsi. Jednak okazuje się, że na samym Twitterze przeciętna młoda Japonka operuje średnio 3,4 kontami. Dopytywani o rodzaj relacji międzyludzkich młodzi przyznają, że gdyby tylko się dało, chętnie zbudowaliby je od nowa, resetując niejako dotychczasowe kontakty. 40\% studentek wybiera taką możliwość"22.

\section{Podsumowanie}

Podsumowując uważam, że Japonki znacznie rzadziej niż polskie matki rozpieszczają swoje maluchy. Przede wszystkim dziecku się nie nadskakuje. Latorośl ma być samodzielna i pracowita. Nie pobłaża się dzieciom przy stole, przy posiłkach, nie wykonuje się za nich obowiązków. Uczone są, by brać odpowiedzialność za swoje czyny, zawsze zachowywać

21 D. Hałasa, Życie codzienne w Tokio, Warszawa 2004.

22 R. Tomański, Jacy sq..., op.cit. 
się nienagannie, wyrażać innym należyty szacunek i porządnie wykonywać swoje obowiązki. Przykładem uczenia dzieci samodzielności i odpowiedzialności może być obowiązek sprzątania pomieszczeń szkolnych przez uczniów lub fakt, że rodzice nie odprowadzają swoich podopiecznych do szkoły - dzieci chodzą do szkoły w grupach lub z osobnikami ze starszych klas. Wychowanie dzieci odbywa się głównie poza domem, gdyż dzieci i młodzież spędzają znaczną część dnia w szkole, a następnie na zajęciach dodatkowych, w klubach szkolnych, na korepetycjach lub w szkołach przygotowujących do zbliżających się egzaminów. Japończycy bardzo cenią sobie wartości rodzinne. Coś, co czyni Japończyków wyjątkowymi są rodzinne relacje między różnymi pokoleniami. Więzi między osobami starszymi a młodymi charakteryzują się większą empatią i czułością niż w jakiejkolwiek innej części świata. Dla młodych osoby starsze są pełne mądrości i zasługują na najwyższą uwagę. Z kolei starsi ludzie postrzegają dzieci i młodzież jako dorosłych w trakcie szkolenia. Więzi nie są oparte na wymianie przysług, a raczej na poglądzie, że każdy ma swoje własne miejsce.

$\mathrm{Na}$ koniec dwie skrajne opinie:

1. „Niezwykłe jest również zaangażowanie nauczycieli w proces wychowawczy. Japońscy pedagodzy nie ograniczają swojej roli jedynie do przekazywania wiedzy, lecz czują się odpowiedzialni za kształtowanie charakterów swoich uczniów, wyrabianie określonych nawyków i zachowań. Pracowitość, zdyscyplinowanie, skromność, grzeczność - to cechy wpajane dzieciom na każdym etapie edukacji. Japońska szkoła dużo wymaga, lecz równocześnie przygotowuje do dorosłego życia i pełnienia określonych ról społecznych (przede wszystkim - zawodowych). 
W społeczeństwie, w którym najwyżej ceni się takie wartości, jak praca zespołowa, jednomyślność, umiejętność pracy zespołowej, poświęcenie dla grupy (enryo), ten rygorystyczny i dość autorytarny system oświatowy sprawdza się doskonale. W zgodnej ocenie Japończyków i zachodnich ekonomistów to właśnie wysoki poziom szkolnictwa umożliwił Krajowi Kwitnącej Wiśni odniesienie gospodarczego sukcesu i zapewnił miejsce wśród największych potęg technologicznych świata"23.

2. Wygłoszone słowa Radiu Watykańskiemu emerytowanego biskupa pomocniczego Tokio Katsuhiro Morii: „Jednym z najpoważniejszych problemów wśród japońskiej młodzieży jest rosnąca liczba samobójstw. Stanowią one statystycznie pierwszą przyczynę śmierci wśród młodych ludzi. W obecnym systemie edukacji nie ma miejsca na nauczanie religii, a młodzi pytają: po co i dla kogo żyją. Na te pytania nie znajdują odpowiedzi (...). Problemem są rodziny, w których się nie rozmawia, nie ma wich miejsca na spotkanie. Rodzice zbyt wiele pracują, nie mają czasu. 60 proc. uczniów podstawówek samotnie jada posiłki, potem ta liczba jeszcze rośnie. W ten sposób nie buduje się relacji i ludzkich więzów. Młodzi Japończycy się bawią, są bardzo aktywni, ale w głębi serca brakuje fundamentu międzyludzkich relacji i problemy duszą w sobie"24.

I gdzie do końca jest prawda?

23 System edukacyjny w Japonii. Blaski i cienie szkolnictwa w Kraju Kwitnącej Wiśni, https://ideologia.pl/system-edukacyjny-w-japonii/ [dostęp: 15.12.2020].

24 Japoński biskup: ważne słowa Franciszka do młodych, https:// www.vaticannews.va/pl/swiat/news/2019-11/pielgrzymka-japonia-franciszek-mlodzi-mori.html [dostęp: 15.12.2020]. 


\section{Bibliografia}

Cylkowska-Nowak M., Butkiewicz A., Street Fashion of Japan jako próba konstruowania tożsamości młodzieży japońskiej, „Przegląd Pedagogiczny” 2009, nr 1 (11).

Cylkowska-Nowak M., Równość możliwości w edukacji japońskiej - kontynuacja i zmiana, „Teraźniejszość - Człowiek - Edukacja” 2009, nr 1 (45).

Czerkawski K., Коти zostaje zimny ryż, „Życie”, 18-19.09.1999. Demusiak K., Ludy starożytnej Japonii, Warszawa 2007.

Figuła J., Wartości narodowe a konkurencyjność Japonii, „Ekonomia - Wroclaw Economic Review” 2014, nr 20/1. Hałasa D., Życie codzienne w Tokio, Warszawa 2004. Japan school to teach patriotism, „BBC News”, 18 maja 2007. Japonia. Parlament przyjat ustawę $w$ sprawie nauczania patriotyzmu w szkołach, „PAP”, 15.12.2006.

Mrowiec M., Inspiracje popkultura w modzie japońskiej od lat siedemdziesiatych XX wieku. Kawaii na przykładzie japońskiej mody ulicznej, [w:] 50 twarzy popkultury, red. K. Olkusz, Kraków 2017.

Korzycki R., Emancypantki, „Polityka” 2006, nr 15 (2550).

Suzuki T.M., A History of Japanese Economic Thought, London-New York 1989.

\section{Netografia}

Dominia J., Chinczycy wychowuja bez pieluch, Skandynawowie bez stresu, a Francuzi zostawiaja niemowlaka z nianiq i jada na urlop, https://www.wysokieobcasy.pl/ wysokie-obcasy/56,176062,21847315,japonia-czyli-niejestes-najwazniejszy,,3.html?disableRedirects=true.

Japońskie dzieci - dlaczego sa postuszne i nie dostaja napadów wściekłości?, https://pieknoumyslu.com/japonskiedzieci-dlaczego-posluszne/. 
Sak K., Wartości w naszym życiu, http://zslatowicz.pl/bezkategorii/wartosci-w-naszym-zyciu/.

Shinzō Abe, Wikipedia, https://pl.wikipedia.org/wiki/Shinz\%C5\%8D_Abe.

System edukacyjny w Japonii. Blaski i cienie szkolnictwa w Kraju Kwitnacej Wiśni, https://ideologia.pl/system-edukacyjny-w-japonii/.

Tomański R., Jacy sq młodzi Japończycy? „Rzeczpospolita”, 22.04.2015, https://www.rp.pl/artykul/1195650-Jacy-sa-mlodzi-Japonczycy-.html.

Wartości, https://zslatowicz.pl/wp-content/uploads/2019/ 10/wart.jpg.

Wychowanie i edukacja w Japonii, http://marzeojaponii.blogspot.com/2014/12/wychowanie-i-edukacja-w-japonii-cz-1.html.

\begin{abstract}
Abstrakt
Japonia to kraj, który jest powszechnie i dość stereotypowo kojarzony z samurajami, zimnym sake, bezwzględną Yakuzą, gejszami, mangą, anime oraz z kobietami ubranymi w kimono, wiecznie zapracowanymi biznesmenami w ciemnych garniturach i ich śmiercią z przepracowania; jak również z grzecznością, czystością, wysoko rozwiniętą technologią i bezpieczeństwem. Mniej uwagi poświęca się różnorodnym przejawom współczesnego życia Japończyków, a zwłaszcza zmianom, które zachodzą w Japonii. W artykule podjęta zostanie próba przybliżenia czytelnikowi interesującego zjawiska kulturowego kreowanego przez japońską młodzież. Młodzież japońska bardzo różni się od rodziców i dziadków swoim światopoglądem oraz wyznawanymi wartościami. Dzieci swoim zachowaniem dają jasny sygnał, że nie chcą być częścią społeczeństwa, w którym najwyższymi wartościami są uniformizacja, hierarchia oraz dyscyplina. W społeczeństwie japońskim najwyżej ceni się takie wartości, jak: jednomyślność, umiejętność pracy zespołowej, poświęcenie dla gru-
\end{abstract}


py (enryo). Grupa wyznacza wartości, którymi muszą się kierować jej członkowie. O ile w kulturze zachodniej człowiek odpowiada za swoje czyny przed własnym sumieniem, o tyle w Japonii - przed grupą.

Słowa kluczowe: wychowanie, młodzież, Azja, wartości, Japonia, grupa

\begin{abstract}
Japan is a country that is commonly and quite stereotypically associated with samurai, cold sake, ruthless Yakuza, Geisha, manga, anime and with kimono-clad women, busy businessmen in dark suits and their death from overwork; as well as with politeness, cleanliness, highly developed technology and safety. Less attention is paid to the various manifestations of contemporary Japanese life, especially the changes that are taking place in Japan. The article attempts to introduce the reader to an interesting cultural phenomenon created by Japanese youth. Japanese youth are very different from their parents and grandparents in their worldview and professed values. Children by their behaviour give a clear signal that they do not want to be part of a society in which the highest values are uniformity, hierarchy and discipline. In Japanese society, the most valued are values such as teamwork, unanimity, teamwork, and dedication to the group (enryo). The group sets the values that its members must follow. While in Western culture a person is responsible for his actions to his own conscience, in Japan - to a group.
\end{abstract}

Keywords: Education, youth, Asia, values, Japan, group 


\section{Iwona Grodź}

Polskie Towarzystwo Badań Filmu i Mediów

ORCID ID: https://orcid.org/0000-0003-0151-6909

\section{Akira Kurosawa: artysta między Wschodem a Zachodem}

Można go nazwać człowiekiem wszystkich rodzajów, wszystkich okresów, wszystkich miejsc, łączącym w swoich dziełach tradycję z nowoczesnością, stare z nowym, kultury Wschodu

z Zachodem.

Każdy z jego filmów historycznych posiadał aktualną wymowę i, tak jak jego współczesne filmy, charakteryzował się silnym współczuciem dla swoich bohaterów, głębokim, ale niesentymentalnym, prawie szorstkim humanizmem, który łagodził otaczającą ich przemoc i otaczał ich nieustanną troską z powodu dwuznaczności ludzkiej egzystencji.

Bert Casrdullo o Akirze Kurosawie

\section{Wprowadzenie}

Słynny japoński filozof Kitarō Nishida w tekście na temat starożytnych form kulturowych Wschodu i Zachodu, w perspektywie metafizycznej, zadał kluczowe pytanie o różnice między nimi. Jego odpowiedź brzmiała: „Myślę, że można wyróżnić dwa podstawowe podejścia - jedno z nich widzi podstawę rzeczywistości w bycie, drugie w nicości. Można też mówić o podziale na rzeczywistość jako formę i rzeczy- 
wistość bez formy" ${ }^{1}$. Jest w tym stwierdzeniu wiele prawdy, ale i wartościowania. Dlatego warto przypomnieć też o ustaleniach, m.in. europejskiego socjologa Jerzego Szackiego ${ }^{2}$, dotyczących kultury europejskiej, uznawanej przez mieszkańców Azji za zachodnią. Polski socjolog już we wstępie swoich rozważań podkreśla, że trudno jest pisać o niej w ogóle, a w szczególności o jej kanonie. Już to ostatnie słowo „kanon” Szacki określa jako kłopotliwe, gdyż kojarzy się z czymś pewnym i stałym (u „źródeł takiego myślenia leży przeświadczenie o istnieniu wartości wspólnych i wiecznych", kanon sugeruje też istnienie wspólnoty), a przecież kultura to polifoniczność i zmienność. To obecnie istna „wieża Babel”. Dlatego nawet uznanie Homera, Szekspira czy Goethego za twórców kanoniczych dla Europy może budzić zastrzeżenia. Autor wskazanego eseju stwierdza więc, że „obowiązujący aktualnie kanon kultury nie wszystkim musi wydawać się oczywisty i zasługujący na szacunek”3.

1 K. Nishida, Starożytne formy kulturowe Wschodu $i$ Zachodu w perspektywie metafizycznej, tłum. A. Kozyra, „Japonica” 1999, nr 10, s. 143.

2 J. Szacki, O kanonie kultury europejskiej uwagi sceptyczne, „Znak” 1994, nr 470 (tekst dostępny on-line: https://opoka.org.pl/biblioteka/I/IS/ kanon03.html [dostęp: 6.12.2020], por. też rozdział o europocentryzmie z książki Leszka Kołakowskiego, Czy diabet może być zbawiony i 27 innych kazań, Londyn 1984.

3 Ibidem. Por. też m.in. pojęcie nihonjinron - „odnoszące się do ideologii kulturowego nacjonalizmu, którego misją jest podkreślanie i ugruntowywanie założeń o kulturowej wyższości kultury japońskiej. Można powiedzieć, że ideologia nihonjinron stanowi swego rodzaju odwrócenie założeń orientalistycznych i jest odpowiedzią na etnocentryzm, obecny (często nawet współcześnie) w zachodnich rozważaniach na temat Japonii" (zob. P. Szarota, Japoński uśmiech: orientalistyczna inwencja czy skrypt kulturowy?, „Lud” 2007, t. 91, s. 139). Zob. też: https://www.researchgate.net/publication/267151989_Japonski_usmiech_orientalistyczna_inwencja_czy_skrypt_kulturowy_The_Japanese_smile_An_Oriental_invention_or_a_cultural_script [dostęp: 6.12.2020]. 
Innym kłopotliwym, jeżeli chodzi o definicję, słowem jest „kultura”, które - jak pisał autor sceptycznych uwag o kanonie europejskim:

(...) nie uzyskało nigdy sensu czysto opisowego, zachowując silny odcień pozytywnego wartościowania. Kulturę przeciwstawia się odruchowo barbarzyństwu, a pojęcie swoistej kultury barbarzyńców wydaje się wewnętrznie sprzeczne. W rezultacie, charakteryzując swoją kulturę, jesteśmy skłonni eksponować to, co w niej dobre i piękne, spychając w cień pytanie, jacy faktycznie byliśmy i jesteśmy $y^{4}$.

Ostatecznie okazuje się, że w myśleniu o różnicach kulturowych nie chodzi o to, co różni poszczególne kultury, ale to, „jakie jest ich wyobrażenie idealne”. Wschód i Zachód jest wszak mieszaniną wartości pozytywnych i negatywnych. Ich reprezentacje w sztuce, także filmowej, są wynikiem wyobrażeń, które podlegają mechanizmom: selekcji, detrakcji, inwersji, transmutacji, rzadziej addycji, a więc różnym odmianom cenzury. Dojrzałość zakłada umiejętność wskazania tych cech kultury Wschodu i Zachodu, które nie tylko oznaczają ich afirmację, ale także ujawniają stanowisko krytyczne (wskazuje to, co budzi wstyd, jest kontrowersyjne lub już nieaktualne). W takiej postawie, zdaniem Szackiego, tkwi zrozumienie, „iż każda kultura jest kłębowiskiem sprzeczności, a nie pomnikiem, wykutym z najszlachetniejszego kruszcu"6.

Wspólna tożsamość tworzona jest przez dziedzictwo. Jednak, żeby go zrozumieć i docenić trzeba być wykształconym i zdawać sobie sprawę z zakorzenienia „we współczesnym doświadczeniu i przekonaniu, iż łączą nas nie tylko wspomnie-

\footnotetext{
4 J. Szacki, O kanonie kultury europejskiej uwagi sceptyczne, op.cit.

5 Ibidem.

6 Ibidem.
} 
nia i pamiątki" . Trzeba mieć też świadomość skomplikowania relacji międzykulturowych, a więc zarówno interkulturowych - pomiędzy wieloma kulturami, jak i intrakulturowych - wewnątrz jednej kultury czy transkulturowych - utożsamianych z wielopoziomowym przenikaniem i hybrydyzacją, jednocześnie między, jak i wewnątrz, badanej kultury. Dopiero taka świadomość i wiedza pozwala odpowiedzieć, m.in. na pytanie: kim był tak naprawdę Akira Kurosawa? W tym miejscu encyklopedyczna odpowiedź, że jednym z najbardziej znanych japońskich reżyserów, nie może już satysfakcjonować 8 . Ważniejsze jest bowiem dookreślenie i sprecyzowanie. Czy przede wszystkim: poszukującym wszędzie inspiracji Artystą (o niebagatelnym wpływie na innych, także azjatyckich, twórców $\left.{ }^{9}\right)$ ? A może raczej „obrońcą” rodzimej tradycji? Trudno na

\section{Ibidem.}

8 Akira Kurosawa debiutował, zrealizowaną w czasie wojny, Sagq o ḋ̇udo (1943). Najważniejsze i najbardziej znane, też na Zachodzie, filmy tego reżysera to ponadto: Pijany anioł (1948), Rashōmon (1950), Idiota (1951), Siedmiu samurajów (1954), Na dnie (1957), Tron we krwi (1957), Ukryta forteca (1957), Zly śpi spokojnie (1960), Straż przyboczna (1961), Sanjūrō: samuraj znikąd (1962), Rudobrody (1965), Dersu Uzata (1974), Sobowtór (1980), Ran (1985), Sny (1990), Sierpniowa rapsodia (1991), Madadayo (1993). Japoński artysta był laureatem wielu najważniejszych nagród w świecie filmu, m.in. „Złotego Lwa” na 12. MFF w Wenecji za film Rashōmon (1950), „Srebrnego Lwa” na 15. MFF w Wenecji za Siedmiu samurajów (1954), „Złotej Palmy” na 33. MFF w Cannes za film Sobowtór (1980). Zdobył też dwa „Oscary” dla najlepszego filmu nieanglojęzycznego za filmy Rashōmon (1950) i Dersu Uzała (1975) oraz „Honorowego Oscara” za całokształt twórczości w 1989 r.

9 Margaret Hillenbrand wskazywała na przykład na intrygujący związek kina chińskiego Zhanga Yimou z twórczością Kurosawy. Zdaniem tej autorki twórca Hero „przejmuje, adaptuje, a nawet wywłaszcza styl Kurosawy, aby stworzyć zmysłowo [chodzi przede wszystkim o symbolikę barw - przyp. I.G.] jednoczący język filmowy, który przeformułowuje ostatnie koncepcje dotyczace tak zwanego kina panazjatyckiego (...)". Zob. M. Hillenbrand, "Hero", Kurosawa and a cinema of the senses, „Screen” 2013, vol. 54, nr 2, s. 127-151. 
nie od razu i jednoznacznie odpowiedzieć, ale można pokusić się o pewne spostrzeżenia.

Pomocne mogą się okazać opinie kulturoznawców i filmoznawców na ten temat. Przykładowo Piotr Szarota przypominał: „Zachodnie myślenie i pisanie o Japonii wpisuje się w bogatą tradycję orientalistyczną, a Japonia postrzegana jest jako przeciwieństwo Zachodu"10. Anna Wierzbicka z kolei założyła, że każda kultura dysponuje zestawem „skryptów”, „które komunikowane są nieustannie zarówno poprzez język, jak i niewerbalnie, a które kierują ich zachowaniem"11. Zdaniem wskazanej badaczki „kulturę japońską opisać można najlepiej przy pomocy siedmiu słów-kluczy, które nie poddają się przekładowi na inne języki: amae ${ }^{12}$, enryo ${ }^{13}$,

10 P. Szarota przypomniał, że „Jako pierwszy pisał o tym Richard Minear (1980). Zwraca on uwagę na trzy podstawowe elementy obecne w myśleniu orientalistycznym: 1) posługiwanie się abstrakcjami, takimi jak „kultura europejska” i „kultura orientalna”, 2) przekonanie o wyższości tej pierwszej, 3) przeciwstawianie dawnej wielkości kultury Orientu i jej obecnej degradacji. Wszystkie te trzy elementy odnajduje Minear w zachodnim piśmiennictwie poświęconym kulturze japońskiej. (...) Podziw miesza się w opisach Japonii i Japończyków ze strachem i pogardą, mamy tu do czynienia ze znacznie większą ambiwalencją i zniuansowaniem niż w wypadku opisów świata arabskiego. Z jednej strony widzimy zachwyt nad wyrafinowaniem kultury japońskiej, estetyką jedzenia, utrzymywaniem harmonii z naturą, mistyką buddyzmu zen, z drugiej - pogardę dla «konformizmu» Japończyków, strach przed ich »fanatyzmem«, »okrucieństwem « i »hipokryzją«". Zob. P. Szarota, Japoński uśmiech: orientalistyczna inwencja czy skrypt kulturowy?, op.cit., s. 138.

11 A. Wierzbicka, Słowa klucze. Różne języki - różne kultury, tłum. I. Duraj-Nowosielska, Warszawa 2016 (zob. szczególnie część VI Japońskie stowa klucze a podstawowe wartości japońskiej kultury, s. 431-511).

12 Amae - „liczenie na czyjąś uprzejmość, poleganie na czyjąś życzliwość, brak samodzielności, brak niezależności”. Zzob. m.in. F. Mazurek, Mały skromny japoński słownik, s. 120, https://www.japonski-pomocnik. pl; https://play.google.com/store/apps/details?id=pl.idedyk.android.japaneselearnhelper [dostęp: 6.12. 2020].

13 Enryo - „rezerwa, skrępowanie, skromność, nieśmiałość, wahanie”. Ibidem, s. 908. 
$w a^{14}$, on $^{15}$, giri $^{16}$, seishin ${ }^{17}$ i omoiyari" ${ }^{18}$. Z uwagi na to, że zasadniczym tematem tych rozważań jest film, czyli sztuka obrazu, dodać można też kategorię estetyczną: wabi-sabi ${ }^{19}$. Crispin Sartwell pisał o tym w kontekście piękna, sugerując, że jest to japońskie wyobrażanie na ten temat, tożsame ze zgodą na paradoks piękna „niedoskonałego” („Japanese humility imperfection ${ }^{20}$. Piękno, o którym mowa jest tożsame z pokorą, prostotą i zgodą na autentyzm. W przypadku filmu Ran kluczowe znaczenie mają: wa, omoiyari i enryo.

Wa oznacza wartości, takie jak harmonia i działanie we wspólnocie (poczucie jedności), przypominali Anna Wierzbicka i Piotr Szarota, które stoją u podstaw japońskiej orga-

$14 W a$ - „suma, harmonia, pokój, japoński styl”. Ibidem, s. 5996.

15 On - „łaska, życzliwość” (Ibidem, s. 4008).

16 Giri - „czyli obowiązek, dług wdzięczności”. Ibidem, s. 1209.

17 Seishin - „psychika, duch, serce, umysł, wola, intencja, motyw”. Ibidem, s. 4690-4691.

18 Omoiyari to „empatyczna umiejętność wyczuwania nastrojów innych oraz gotowość do rozumienia cudzych niewypowiedzianych na głos życzeń i pragnień". Zob. m.in. wyjaśnienie: P. Szarota, Japoński uśmiech: orientalistyczna inwencja czy skrypt kulturowy?, op.cit., s. 141.

19 Wabi-sabi - „poczucie estetyki w sztuce japońskiej skupiającej się na akceptacji przemijalności i niedoskonałości”. Zob. F. Mazurek, Mały skromny japoński słownik, op.cit., s. 6001.

20 C. Sartwell, Six Names of Beauty, London 2013. Piękno w różnych językach: a) „beauty” English the object of longing; b) „yapha” Hebrew glow bloom; c) „sundara” Sanskrit holiness; d) „to kalon” Greek idea ideal; e) „hozho” Navajo health harmony. C. Sartwell podkreślał: „W potocznym rozumieniu filozofia wabi-sabi powstała z połączenia dwóch pojęć. „Wabi oznacza pokorę i prostotę, życie w zgodzie z naturą, opisuje osobę, która zadowala się tym, co ma, i gotowa jest ograniczać swoje potrzeby. $S a b i$ wiąże się zaś z upływem czasu, dotyczy przemijalności i piękna naturalnego starzenia się. Praktykowanie sabi to zgoda na naturalny cykl narodzin i śmierci, a także zachwyt nad niedoskonałościami, jakie niesie ze sobą życie. W połączeniu wabi i sabi oddają określony światopogląd i sposób odczuwania skoncentrowany na harmonii i autentyzmie tego, co proste, skromne, tajemnicze i efemeryczne". 
nizacji społecznej. Ceną wa jest przedkładanie dobra grupy nad własne interesy (rezygnacja z indywidualizmu i wolności), to podstawa „kulturowego kolektywizmu”. Wbrew stereotypowym wyobrażeniom chodzi tu o doskonałość. Kompromis uzyskany poprzez dialog, a nie przymus. Ważna jest też kwestia postrzegania „ja”. W zbiorowości chodzi o „ja współzależne” (utrzymanie społecznej harmonii), a w kulturach indywidualistycznych - „ja niezależne”, a więc „wolne” od kontekstu społecznego i skierowane na samorealizację. Japończycy wiedzą, że nie można ujawniać uczuć, które mogą zagrozić harmonii z innymi (światem w ogóle). To empatyczne nastawienie na samopoczucie drugiego człowieka jest istotą drugiego wskazanego słowa-klucza omoiyari $^{21}$. W centrum uwagi są niedostrzegane informacje kontekstowe, łączeniu drobiazgów, drobnych zmian mimiki, wyrazu oczu czy gestów, co w obiegowej opinii może być obce ludziom Zachodu. Japonia kojarzy się w tym kontekście, w myśl tradycji konfucjańskiej, z powściągliwością ${ }^{22}$. W tym miejscu nie można nie wspomnieć też o enryo, czyli skromności i powściągliwości „w kontaktach społecznych, powstrzymywanie się przed otwartym wyrażaniem swoich opinii, pragnień, preferencji. Zachodnia bezpośredniość

21 Piotr Szarota pisał też o rozróżnieniu na tatemae i honne. „Tatemae to fasada, którą pokazuje się najczęściej światu, oznacza ona postępowanie według kulturowych standardów uprzejmości. Honne to prywatne, wewnętrzne przekonania, którymi dzielić się można tylko z wybranymi bliskimi osobami i to zazwyczaj tylko w pewnych okolicznościach. Nie ma sytuacji, w której tatemae nie byłoby stosowane dla "zachowania twarzy”, uniknięcia konfliktów, sytuacji niewygodnych czy zawstydzających". Zob. P. Szarota, op.cit., s. 147.

22 Twarz jako zwierciadło duszy to stały motyw filmów Kurosawy. Dodatkowo Szekspir, autor pierwowzoru Ran, pisał, że „twarz to tablica, na której można czytać skryte rzeczy”. Por. ibidem, s. 141. 
w tym względzie traktowana jest jako przejaw »niedojrzałości« (...)”23.

Podsumowując wstępne rozważania i ujęcie ogólne na Wschód i Zachód warto pamiętać, że słowa mogą być symbolicznymi przewodnikami po kulturze, bo ujawniają sposób myślenia użytkowników. Są więc jak klucze do wartości danej kultury ${ }^{24}$. Przykładowo można zadać pytanie, co znaczy tytułowe (nieprzetłumaczone na języki zachodnie) słowo Ran? Najprostsze tłumaczenie to „rebelia”, „powstanie” „bunt”. W lakoniczny sposób opisuje ono przebieg wydarzeń we wskazanym filmie Kurosawy. Sięgając jednak głębiej, do znaczeń naddanych, można zauważyć, że oznacza ono tė̇ „przekraczanie metaforycznej granicy”, zarówno przez bohaterów filmu, jak i samego reżysera, między tym, co związane z kulturą Wschodu, a tym co jest jej obce. W tym ujęciu, tradycja uwikłana w postrzeganie życia w kontekście „bycia”, a rzeczywistości jako „forma”, przechodzi w swoje przeciwieństwa, czyli „nicość” i „brak formy/ładu”. Jest to efekt sprzeniewierzenia się niepisanym zasadom typowym dla „kultury kolektywistycznej”, opartej na poczuciu podległości i obowiązku. Kurosawa robi krok w kierunku przekroczenia tych zasad (w kierunku ujawnienia cech „kultury indywidualizmu"), pokazując bunt, bohaterów filmu, w których prawa pojedynczych ludzi są ważniejsze od obowiązków wobec grupy $^{25}$, w tym rodziny (on - jest przynajmniej częściowo anulowane, podobnie jak empatia/omoivari). Z tego względu

23 Ibidem, s. 147.

24 A. Wierzbicka, Słowa klucze. Różne języki - różne kultury, op.cit., s. $15,22,41$.

25 A. Wierzbicka przypominała o stereotypie, według którego ludzie na Zachodzie są bardziej zorientowani na prawa, a na Wschodzie na obowiązki. Ibidem, s. 465. 
poleganie na czyjejś dobrej woli (amae) zastępuje brak takiej pewności. Pociąga to za sobą utratę poczucia harmonii (wa) oraz zmniejszenie dystansu (enryo). Sprawiedliwość i prawość (giri) wystawiona zostaje na próbę, a materia (ciało) i pożądanie władzy okazują się ważniejsze od umysłu czy tego, co duchowe (seishin). Nie można na pewno powiedzieć, „do jakiego stopnia opisane wyżej kulturowe zależności są specyficzne dla Japonii, a do jakiego stopnia charakterystyczne są dla większości kultur kolektywistycznych Dalekiego Wschodu"26. Czy zatem w Ran można wskazać posługiwanie się „kulturowym skryptem”? Czy próbą jego przełamywania? Wydaje się, że ten pierwszy jest wskazany przez Kurosawę tylko pod to, aby można było podjąć z nim twórczy dialog, a więc też wyrazić sprzeciw (opór) i ich konsekwencje.

\section{Akira Kurosawa i film $\operatorname{Ran}(1985)$}

Plakat do filmu Ran, reż. Akira Kurosawa

Źródło: domena publiczna.

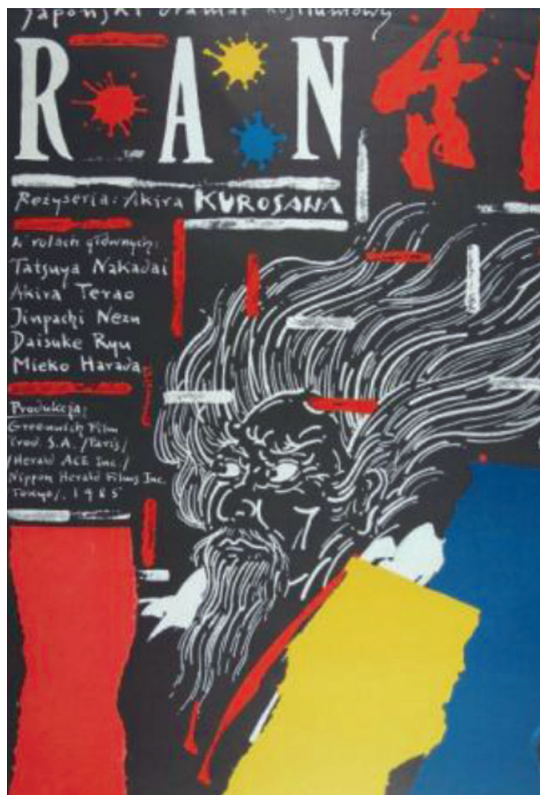

26 Ibidem. 
Czy zdrajca zdradza także siebie? (fragment ścieżki dźwiękowej filmu Ran)

Akira Kurosawa (1910-1998) przez wielu nazywany był „cesarzem" kina ${ }^{27}$, w przeciwieństwie do Yasujirō Ozu (1903-1963) określanego „mnichem” wschodniej kinematografii. Tym samym podkreślano „ekspresyjność” (skierowanie na zewnątrz) artystycznej osobowości tego pierwszego. Alicja Helman, charakteryzując osobę Akiry Kurosawy, już przed laty napisała ponadto, że „był on dla kina tym, kim dla muzyki był Bach, a dla teatru Szekspir"28. Trudno się z tym stwierdzeniem nie zgodzić. Warto jednak powrócić do, sygnalizowanego już wcześniej, tematu stale obecnej synergii kultury Wschodu i Zachodu w twórczości autora filmu Ran. Tym bardziej, że kino Kurosawy, m.in. poprzez nawiązania do kultury Zachodu, pozwala spojrzeć na tradycję Wschodu jako aktualizację przeszłości. Jest to też nawiązanie „twórczego" - bo bez „odcinania” się od korzeni, a więc wschodniej tożsamości - dialogu ze współczesnością. Dla tych rozważań istotne jest też zwrócenie uwagi, że w swoim rodzimym kraju Kurosawa był uważany za twórcę „zachodniego" ${ }^{29}$. Opinia ta brała się przede wszystkim z faktu adaptowania przez niego zachodniej literatury ${ }^{30}$, np. Makbeta (zob. Tron we krwi w 1957 r.)

27 Zob. m.in. Ł. Kamiński, O twórczości cesarza kina japońskiego w 100. rocznice urodzin, „Humanistyka i Przyrodoznawstwo” 2014, nr 20, s. 635-638.

28 Zob. A. Helman, Akira Kurosawa, Warszawa 1970.

29 Por. na temat poczucia wspólnoty między kulturami i filmu Sny w twórczości Kurosawy, m.in. M. Tasiemska, „Sny” Akiry Kurosawy. Mit, symbol, rytuat, Warszawa 2018.

30 Warto pamiętać, że reżyser Siedmiu samurajów adaptował też teksty Maksyma Gorkiego (Na dnia) czy Fiodora Dostojewskiego (Idiota), 
czy Król Lear (zob. Ran, 1985) Wiliama Szekspira ${ }^{31}$. Warto pamiętać też o filmie Zły śpi spokojnie (1960), który nawiązuje do Hamleta.

Ran uważany jest za jeden z najlepszych filmów Kurosawy, choć droga do jego realizacji była trudna i czasochłonna ${ }^{32}$. Od połowy lat 70. reżyser przygotowywał się do nakręcenia filmu, który stanowiłby zwieńczenie jego twórczości, a inspiracją był Król Lear (z 1605). Niestety osobiste problemy i trudności ze zdobyciem pieniędzy potrzebnych na kosztowną produkcję sprawiły, że do realizacji reżyser przystąpił dopiero w lipcu 1983 r., a zdjęcia ukończył blisko dwa lata później. Dlaczego 75-letni Kurosawa zdecydował się powrócić do dramatu Szekspira? Przede wszystkim dlatego, żeby na nowo go odczytać $^{33}$. Krzysztof Loska pisał, że:

które przez Japończyków postrzegane były (zresztą jak cała sztuka Rosji) jako wyraz kultury zachodniej.

31 Niemniej Agnieszka Kamrowska zatytułowała część na temat Tronu we krwi - Szekspir i teatr nō. Zob. A. Kamrowska, Przeszłość i teraźniejszość w filmach „jidai-geki" Akiry Kurosaway, [w:] Okna na przyszłość $z$ historii wizualnej. Szkice z historii wizualnej, t. 2, red. D. Skotarczak, J. Szymala, Kraków 2020, s. 96-100.

32 Ran to francusko-japońska koprodukcja. Jego scenariusz napisali Hideo Oguni i Akira Kurosawa na podstawie Króla Leara Williama Shakespeare'a. W 1985 r. zdobył on „Oscara” za najlepsze kostiumy. Dominacja obrazu nad słowami była w twórczości autora Snów motywowana tym, że wzrok jest zmysłem, który pozwala najaktywniej kodować przekazywane treści, a dzięki obrazom tradycja japońska miała szansę docierać do widzów bezpośrednio. Autorem ścieżka dźwiękowa do filmu był Toru Takemitsu. Obsada: Tatsuya Nakadai (jako lord Hidetora Ichimonji), Akira Terao (Taro), Jinpachi Nezu (Jiro), Daisuke Ryu (Saburo), Mieko Harada (lady Kaede), Yoshiko Miyazaki (lady Sue), Masayuki Yui (Tango), Peter (błazen Kyoami), Kazuo Kato (Kageyu Ikoma), Hitoshi Ueki (Nobuhiro Fujimaki), Norio Matsui (Ogura), Mansai Nomura (Tsurumaru), Hisashi Igawa (Kurogane), Takeshi Kato (Koyata Hatakeyama), Kenji Kodama (Shirane). Zob. scenariusz filmu autorstwa A. Kurosawy Ran, tłum. T. Shishido, Boston 1986.

33 Odpowiednikiem króla Leara jest $\mathrm{w}$ filmie Hidetora Ichimonji, starzejący się arystokrata, pan feudalny. Zamiast córek ma on trzech synów: Taro, Jiro i Saburo, który jest odpowiednikiem szekspirowskiej Cordelii. 
początkowo Kurosawa zamierzał przedstawić alternatywną wersję historii Motonariego Mōri (1497-1571), wielkiego wodza z czasów wojen domowych (sengoku jidai), i jego trzech wiernych synów. Pragnął w ten sposób odpowiedzieć na pytanie, co by się stało, gdyby dzieci zapomniały o powinnościach wobec ojca. Pozostałością po tym pomyśle fabularnym jest jedna z pierwszych scen, rozgrywająca się tuż po polowaniu na dzika, kiedy to 70-letni władca Hidetora Ichimonji (Tatsuya Nakadai) opowiada swym synom przypowieść o trzech strzałach, które z osobna są kruche, ale połączone razem - twarde jak stal. Najmłodszy z synów, Saburō (Daisuke Ryū), ucieka się do podstępu i łamie strzały na kolanie, sprowadzając na siebie gniew ojca. Sekwencja inicjalna służy wprowadzeniu zasadniczych tematów i głównych postaci dramatu, pokazuje jednocześnie, w jaki sposób Kurosawa zamierza czytać Szekspira, przekonuje o jego oryginalnym podejściu do pierwowzoru literackiego. Nie chodzi wyłącznie o odmienność kontekstu kulturowego, który warunkuje przecież każdą interpretację dzieła sztuki, ani nawet o napięcie między konwencjami teatru elżbietańskiego a japońską tradycją estetyczną, ale o swoiste przetworzenie materiału przez reżysera, wejście w dialog z tekstem dramatu, wypracowanie własnego języka wizualnego bez uciekania się do prostych transpozycji oraz ilustracyjności ${ }^{34}$.

Ostatecznie wszystko zostało w japońskiej adaptacji dopracowane i misternie przygotowane. Ten niezwykle piękny i zrealizowany z rozmachem film w lakonicznym skrócie opowiada o ludzkiej naturze. Akcja rozgrywa się w scenerii średniowiecznej Japonii ${ }^{35}$. Jej bohaterem jest król Hidetora Ichimonji (w tej roli Tatsuya Nakadai), który w wieku 70. lat

34 K. Loska, „Ran”, czyli Szekspir po japońsku, „Kwartalnik Filmowy” 2014, nr 87-88, s. 160-170.

35 Zob. m.in. J. Tubielewicz, Historia Japonii, Wrocław 1984, s. $198-$ -2000 . 
postanawia przekazać władzę najstarszemu synowi Taro (Akira Terao), a pozostałych dwóch (Jiro i Saburo) obdarować dobrami. Niestety jego plany pokrzyżują namiętności targające braćmi oraz zemsta synowej (lady Kaede - w tej roli wystąpiła Mieko Harada) ${ }^{36}$. Ostatecznie starzec zostaje odtrącony przez swoich synów i jest zmuszony tułać się wraz z Tango (Masayuki Yui) i błaznem Kyoami (Peter). W ostatniej części filmu spotyka jednak najmłodszego syna, dosiadają razem białego konia, który - jak przypominał Krzysztof Loska - „w mitologii ludowej reprezentuje śmierć, ale w religiach Wschodu wiąże się z osobą Buddy"37. Jest to początek drogi do oświecenia króla, a więc też śmierci. W ten sposób film obnaża próżność i fałsz dworskiego życia.

Japoński reżyser wprowadził szereg zmian w filmie względem oryginału. Chodziło mu przede wszystkim o dopasowanie wydarzeń, postaw i sytuacji do realiów średniowiecznej Japonii. Były one już szeroko analizowane, dlatego teraz wystarczy wspomnieć o najważniejszej, o której pisał m.in. Krzysztof Loska tak:

Kurosawa postanowił obdarzyć swego bohatera przeszłością i przenieść w czasy historyczne. Mówił zresztą o tym wielokrotnie w wywiadach, w których podkreślał, że w sztuce Szekspira zaciekawiło go to, czego w niej bra-

36 W skrócie plan ojca polegał na przekazaniu każdemu z synów zamku pod warunkiem, że będą wzajemnie się wspierać i pomagać sobie w potrzebie. Hidetora nie zdawał sobie sprawy z tego, jak bardzo jego decyzja poróżni synów. Dodatkowo żona najstarszego syna króla miała szczególne powody, aby zabiegać o wpływy i skłócić z sobą braci, ponieważ przed laty Hidetora zamordował jej rodzinę. Ważnym elementem jest sen starca, który opowiedział synom już na początku filmu. Hidetoro mówił: „Byłem w dziwnej krainie. Nieskończona dzicz. Szedłem wciąż przed siebie, lecz nikogo nie spotkałem. Wzywatem, wołałem... ale nikt nie odpowiadat. Bytem sam. Sam na wielkim świecie... ale potem wezwał go głos Taro i król zobaczył ukochane dzieci".

37 K. Loska, „Ran”, czyli Szekspir po japońsku, op.cit., s. 160-170. 
kowało, czyli wyjaśnienia przyczyn nieszczęścia. W świecie przemocy, której Hidetora sam jest sprawcą nie było miejsca na wiarę w zasadę bezwarunkowego obowiązku dzieci wobec rodziców (gimu), w miłość synowską $(k \bar{o})$, która wymaga nie tylko posłuszeństwa i szacunku, ale też okazywania prawdziwej troski ${ }^{38}$.

Jest to więc jeden z przejawów dialogu reżysera z kulturą Wschodu, ale nie jedyny. Można go bowiem rozpoznać nie tylko na poziomie wyznawanych wartości i ich podważania, ale także w odchodzeniu od konwencjonalnego podejścia do japońskiego gatunku filmu historycznego jidai-geki ${ }^{39}$. Agnieszka Kamrowska pisała, że Kurosawa „W swojej twórczości po mistrzowsku łączył sprzeczności, budował mosty pomiędzy biegunowo różnymi zjawiskami: tradycją i nowoczesnością, kinem autorskim i gatunkowym, Wschodem i Zachodem, dobrem ogółu i pragnieniami jednostki, przeszłością i teraźniejszością" ${ }^{40}$. Dlatego też Ran jest jednym z filmów japońskiego gatunku jidai-geki, który potwierdza tę konsta-

38 Ibidem.

39 Akcja tych filmów najczęściej rozgrywała się w epoce Edo (tj. w latach 1600-1868), ale nie można ich do końca nazwać filmami historycznymi, bo nie chodzi w nich o rekonstrukcję wydarzeń minionych, ale często ich idealizację. Epoka Edo w wielu japońskich filmach jest fantazją, stylizowaną przeszłością, do której można uciec przed teraźniejszością. Zob. na ten temat też: M. Yoshimoto, Kurosawa. Film Studies and Japanese Cinema, Druham 2000; D. Richie, A Hundred Years of Japanese Film, Tokyo-New York-London 2005.

40 A. Kamrowska, Przeszłość i teraźniejszość w filmach „jidai-geki” Akiry Kurosaway, [w:] Okna na przyszłość z historii wizualnej. Szkice $z$ historii wizualnej, t. 2, red. D. Skotarczak, J. Szymala, Kraków 2020, s. 85. Autorka słusznie przypomina, że „Kino jidai-geki to nie tylko filmy o samurajach, lecz wszystkie obrazy przywołujące przeszłość, nostalgiczne portrety minionej Japonii, które Akira Kurosawa odmalowywał tak, aby za ich pomocą skonfrontować widza ze współczesnością. Osadzone w minionych epokach filmy tego reżysera są parabolami japońskiej teraźniejszości, sceny z odległych czasów stanowią komentarz do aktualnych kwestii społecznych". 
tację. Podobnie, jak inne filmy historyczne tego reżysera, okazuje się w pełni autorską próbą zreformowania konwencji ${ }^{41}$. Staje się też eksperymentem w tym sensie, że pozwala twórcy na wolność artystyczną, a więc „ukrycie” innowacyjności w skostniałym gatunku. Jego film, choć nawiązuje do tradycji teatru japońskiego $n \bar{o}$, malarstwa tuszowego oraz zwojowego, a także rodzimej muzyki, okazuje się mniej jednoznaczny w ocenach ludzi, ich czynów. Jest więc szczerszy, prawdziwszy w przekazie, niż inne filmy tego nurtu. Nie jest jednak dydaktyczny, a raczej wyrafinowany w pragnieniu zmiany stereotypowego sposobu myślenia o Japończykach. Dodatkowo poprzez wykorzystanie najnowszej techniki, staje się atrakcyjny dla młodych widzów należących do różnych kultur ${ }^{42}$.

Pośrednikami między Wschodem i Zachodem są też postaci, nie tyle główna postać - Hidetora, ale bohaterowie ważni, dla rozwoju fabularnego, np. synowa Kaeda ${ }^{43}$ lub choć drugoplanowi - ale będący mediatorami między tym, co typowe dla Wschodu i tym, co sugeruje podjęcie dialogu z jego wizją rzeczywistości. W tym ostatnim przypadku chodzi o postać błazna. Zacznijmy jednak od tej pierwszej.

41 A. Kuroswa zrobił wiele filmów tego gatunku, m.in.: Ci, którzy nadepnęli tygrysowi na ogon, Rashōmon, Siedmiu samurajów, Tron we krwi, Ukryta forteca, Straż przyboczna, Sanjūrō - samuraj znikąd, Rudobrody. M. Yoshimoto pisał, że jego „próby stworzenia nowego typu jidai-geki są kontynuacją nurtu zapoczątkowanego w latach 30. przez Yamanakę i Itamiego". Zzob. M. Yoshimoto, Kurosawa. Film Studies and Japanese Cinema, Druham 2000, s. 238.

42 A. Kamrowska, Przeszłość i teraźniejszość w filmach „jidai-geki” Akiry Kurosaway, op.cit., s. 112.

43 Adrianna Włosińska podkreślała, że choć postać kobieca nie jest główną bohaterkom w filmach Kurosawy, to wielokrotnie jest ona motorem wydarzeń. Tak dzieje się w Tronie we krwi czy właśnie filmie Ran. Zob. A. Włosińska, Wizerunek kobiety i role żeńskich postaci w filmach Akiry Kurosawy, [w:] Okna na przyszłość z historii wizualnej, op.cit., s. $137-160$. 
Kaede to piękna kobieta, która nie może zapomnieć o traumatycznej przeszłości. Choć jest żoną najstarszego syna starego władcy, to od lat planuje zemstę na rodzie swojego męża za krzywdy z przeszłości (śmierć rodziców i oślepienie brata). Filmoznawcy wskazywali, że:

Kaede przypomina ducha zemsty (onryō) z japońskich opowieści niesamowitych, a więc istotę drapieżną i wyrachowaną, wykorzystującą atrakcyjność seksualną do uwodzenia mężczyzn i prowadzenia ich do zguby. (...) Nie zgadza się więc na zajęcie miejsca przypisanego kobiecie w japońskim społeczeństwie patriarchalnym. Po śmierci męża mówi nawet: Nie będę wdowa z krótkimi wtosami ani mniszka zogolona gtowa ${ }^{44}$.

Zmiana Kurosawy polega więc nie tylko na „przekroczeniu" tekstu Szekspira, gdyż w jego filmie jest to postać obdarzona przeszłością i silniejsza niż mogłoby się wydawać, ale przede wszystkim z uwagi na przekroczenie japońskiej konwencji ukazywania kobiet jako postaci podporządkowanych męskiej dominacji. W tym ujęciu kobieta staje się nośnikiem nowych, niemal zachodnich idei ${ }^{45}$.

Postać błazna Kyōami (Peter) wpisuje się natomiast w figurę tricksera (sztuczka, figiel) ${ }^{46}$. David Weiß, pisząc na ten

44 K. Loska, op.cit., s. 160-170. Krzysztof Loska przypomniał, że źródłem tej postaci jest nie tyle dramat elżbietański, co klasycznym teatrze nō i mitologia japońska (por. metafory zwierzęce i ich symbolikę, np. kobieta-lis, kobieta-żmija).

45 Zob. A. Włosińska, Wizerunek kobiety i role żeńskich postaci w filmach Akiry Kurosawy, [w:] Okna na przyszłość z historii wizualnej, op.cit., s. 160.

46 David Weiß w rozdziale: „Dekonstrukcja romantycznego obrazu feudalnej przeszłości Japonii: figura tricksera w filmach jidai geki Akiry Kurosaway", pisał o wybranych postaciach w filmach Kurosawy jako przykładach mitycznej postaci trickstera (kłamca, przechwała, sowizdrzał), np. rolnik-samuraj Kikuchiyo z Siedmu samurajów (1954). Zob. D. Weiß, Dekonstrukcja romantycznego obrazu feudalnej przeszłości Japonii: figura 
temat, nie wspominał co prawda o filmie Ran, ale to postać ważna dla zrozumienia dialogu międzykulturowego, gdyż pojawiająca się we wszystkich mitologiach zachodnich i wschodnich. Trickserzy to indywidualiści, którzy łamią tabu, sprzeciwiają zasadom, są spontaniczni i innowacyjni. Stają się też mediatorami między przeciwieństwami, np. życie-śmierć, kultura-natura, Wschodem i Zachodem. Dlatego bywają określani „bohaterami kulturowymi”, choć trzeba uważać na uogólnienia. Niemniej to postać, która jest ciągle „pomiędzy” i jest obecna w większości filmów Kurosawy gatunku jidai-geki. Pozwala ona Kurosawie przełamać regułę, wprowadzić innowacje, łączyć mądrość z głupotą, komizm z tragizmem, wtajemniczenie ze ślepotą. Dlatego zapewne błazen, towarzyszący Hidetorze od początku jego tułaczki, podważa nawet wiarę w Buddę, wypowiadając bluźniercze słowa:

Czy nie ma bóstw? Nie ma Buddy? Jeśli istniejesz, wysłuchaj mnie! Jesteś okrutny i złośliwy. Nudzi ci się tam, że musisz nas zgniatać jak mrówki? Czy to jest zabawne oglądać płaczących ludzi? Odpowiada mu Tangō, wierny sługa zmarłego władcy, wyrażając poglądy samego reżysera na temat natury ludzkiej: To bogowie nas opłakują. Patrzą, jak zabijamy się wzajemnie wciąż i wciąż, aż nastanie nasz czas. Nie mogą nas chronić przed nami samymi. (...) Ludzie wybierają smutek ponad radość, cierpią zamiast żyć w pokoju.

„Przestrzenią" twórczego dialogu między Wschodem a Zachodem w filmie Ran jest też sfera dźwiękowa ${ }^{47}$. Kurosa-

tricksera w filmach jidai geki Akiry Kurosaway, tłum. M. Lisiecki, [w:] J. Zaremba-Penk, M. Lisiecki, Człowieczeństwo bez granic. Wymiary kultury w twórczości Akiry Kurosawy, Bydgoszcz 2015, s. 55-72.

47 Obszernie pisała o niej Marta Wesołowska, Muzyka do filmów Kurosawy. Whołdzie tradycji, [w:] Okna na przysztość, op.cit., s. 119-136. 
wa znany był z tego, że dzięki muzyce łączył gatunki filmowe, zbliżał przeszłość do przyszłości, a także japońską tradycję (której hołdował) do tendencji zachodnich. Autorem muzyki do wskazanego filmu był Tōru Takemitsu (1930-1996), który potrafił połączyć „kwintesencję japońskiego brzmienia tradycyjnego z XX-wieczną muzyką zachodnią, inspirowaną kompozycjami Arnolda Schönberga (1874-1951) czy Claude'a Debussy'ego (1862-1918)"48. Pierwsza inspiracja związana była z „muzyką przyrody” (np. wykorzystanie świstu wiatru dla podkreślenia opętania Hidetory), użyciem tradycyjnych instrumentów muzycznych: flet shinobue (na którym gra oślepiony przed laty Tsurumaru), kołatka, lutnia biwa, zastosowania japońskiej kategorii rytmicznej ma i efektów dźwiękowych (bębny, okrzyki), charakterystycznych dla muzyki klasycznego teatru nō. Druga polega na wzorowaniu się na Symfonii nr 1 Gystawa Mahlera w scenach walk i gniewu bohaterów ${ }^{49}$. Niemniej w Ran muzyka sygnalizuje „odejście od praktyki pisania kompozycji w stylu zachodnim. Kompozytor eksperymentuje i dowodzi, że te dwie z pozoru odmienne tradycje doskonale się uzupełniają, tworząc wspaniałą muzyczną jedność" 50 .

Podsumowując warto przypomnieć interpretację Krzysztofa Loski, który zauważył:

Zakończenie filmu nie jest tak przygnębiające, jak uważa większość krytyków, którzy pisali o apokaliptycznej wymowie dzieła będącego alegorią chaosu i upadku, albo inaczej - symboliczną wizją człowieka stojącego w obliczu nieodwracalnej katastrofy. Niewątpliwie Kurosawa pesymistycznie spogląda na świat współczesny, nie daje

\footnotetext{
48 Ibidem, s. 133.

49 Ibidem, s. 135-136.

50 Ibidem, s. 136.
} 
pocieszenia, widzi upadek wartości i rozkład porządku społecznego, ale mimo to zachowuje resztki wiary $(. . .)^{51}$.

...wiary we własną przeszłość i tradycję. Tym samym zdaje się mówić, że każdy zdrajca, poniekąd, zdradza też sam siebie.

\section{Zakończenie}

...jesteśmy dziećmi naszych czasów, żyjącymi pomiędzy konfliktem a chaosem. (fragment ścieżki dźwiękowej filmu Ran)

Całkiem niedawno Joanna Zaremba-Penk i Marcin Lisiecki wskazali na paradoks, pisząc: „Akira Kurosawa jest jednym z najbardziej znanych i jednocześnie niedocenionych w Polsce reżyserów filmowych" ${ }^{22}$. Wydaje się, że to efekt powierzchownego obioru filmów tego artysty. Mam na myśli filmy historyczne, które powinny być czytane jednocześnie dosłownie - jako opowieści o feudalnej Japonii i metaforycznie - jako dramaty podejmujące aktualne, bo ponadczasowe i kulturowe, kwestie egzystencjalne i społeczne. W owej polifoniczności tkwi geniusz ich twórcy, który „polega m.in. na umiejętnym wyciągnięciu uniwersalnych elementów z europejskich tekstów kultury i użyciu ich do nakreślenia wątków antropologicznych i zmuszenia widza z innego kręgu kulturowego do refleksji filozoficznej”33.

51 K. Loska, op.cit., s. 170.

52 J. Zaremba-Penk, M. Lisiecki, Człowieczeństwo bez granic. Wymiary kultury w twórczości Akiry Kurosawy, Bydgoszcz 2015.

53 D. Grzonka, Akira Kurosawa: Rytuaty przemocy i szekspirowski teatr zazdrości, styczeń 2011, https://www.researchgate.net/publication/323 738121_Akira_Kurosawa_Rytualy_przemocy_i_szekspirowski_teatr_zazdrosci [dostęp: 6.12.2020], por. też: P. Sawicki, Kurosawa, Wrocław 2015. 
Kino Akiry Kurosawy jest polifoniczne $\mathrm{e}^{54} \mathrm{~m}$.in. dlatego, że uwarunkowane było synkretycznym charakterem kultury japońskiej, jak i czerpaniem inspiracji przez tego twórcę zarówno z kultury rodzimej, jak i obcej ${ }^{55}$. Czy jednak ową inność/obcość udało mu się z sukcesem przezwyciężyć? A może wręcz przeciwnie... chodziło o jej wydobycie, podkreślenie, a więc swoistą afirmację? Na to pytanie próbowała odpowiedzieć na przykład Aneta Pierzchała zadając kluczowe, też dla tych rozważań, pytanie: Czy obcość Japonii wobec kultury Zachodu została przez Kurosawę przezwyciężona? Czy wręcz przeciwnie, stała się obcością pożądaną ${ }^{56}$ Wskazana autorka podkreślała przy tym dynamikę relacji poznający - poznawany. Kto był pierwszym? Kto drugim? Z perspektywy Kurosawy i odbiorców z jego kręgu kulturowego chodziło o poznawanie „obcości” skojarzonej z Zachodem. W ujęciu widza zachodniego, np. europejskiego czy

54 M. Bobrowski, Akira Kurosawa. Artysta pogranicza, Kraków 2012. M. Bobrowski wskazywał na następujące konteksty twórczości Kurosawy, które ów synkretyzm potwierdzały: a) literatura - inspiracje tekstami zachodnich artystów, m.in. Wiliam Szekspir, Fiodor Dostojewski, Albert Camus; b) kino - fascynacja amerykańskim filmem i „zachodnim” gatunkiem jakim jest western; c) filozofia - wyraźne nawiązania do rodzimej filozofii, m.in.: konfucjanizmu, taoizmu, zen.

55 To zagadnienie z obszaru antropologii kultury, które próbowało rozważać wielu badaczy. Przykładowo w Smutku tropików Claude Lévi-Strauss pisał, że wobec „obcych” stosowane są dwie strategie. Pierwsza „antropofagiczna” - polega na "pożeraniu” obcych (dosłownie lub w przenośni) i przeobrażaniu ich, w drodze przemiany materii, w substancję nieodróżnialną od własnej. Druga „antropoemiczna” - sprowadza się do metaforycznego "wymiotowania" obcymi, a więc skazywania ich na banicję czy izolację do wspólnoty. Pod tym kątem, tj. metaforycznego „pożerania i/lub wymiotowania obcości/obcością", można też zanalizować postawę estetyzującą dzieło innej kultury, np. film.

56 A. Pierzchała, Obcość przezwyciężona? Filmy japońskie a kultura europejska, Kraków 2005. Zob. szczególnie rozdział „Pajęcze gniazdo” wokół „Makbeta” Akiry Kurosawy, s. 87-146. 
amerykańskiego, w centrum zainteresowania była inność Wschodu ${ }^{57}$.

Owa zmienność perspektywy i rosnący dystans czasowy (wobec czasu realizacji filmów wybranego artysty) sprawiają, że część filmoznawców traktuje twórczość Akiry Kurosawy jako „akt oporu”, a więc swoistą odpowiedź na groźbę inwazji amerykańskiej. Autorowi Ran chodziło więc z jednej strony o "ratowanie" tradycji (narodowego dziedzictwa, pamięci, z którą skojarzone są powtórzenia i przetworzenia), a z drugiej o modernizację kraju poprzez innowacje w obszarze sztuki po II wojnie światowej. Jednocześnie reżyser rozumiał konieczność myślenia o dialogu międzypokoleniowym i zmianach, które są naturalne i konieczne.

Dialog między Wschodem i Zachodem w sztuce Kurosawy jest więc stałym elementem. Pozwala zachować równowagę między tym, co jest związane z japońską tradycją i tym, co jest powszechne (wspólne dla Japończyków i zachodniego widza). Dlatego tak ważne jest w filmach twórcy Snów ciągłe pamiętanie o dziedzictwie i aktywowanie elementu twórczego, który pozwala je przekazać nowym pokoleniom. Celem każdorazowo jest zachowanie swojej niepowtarzalnej tożsamości ${ }^{58}$.

57 Aneta Pierzchała zauważyła, że już „w latach 50. na Zachodzie rodziła się fascynacja kinem japońskim - uderzają odmienną estetyką, poetyką, ale również zwracają na siebie uwagę «innością» ujęcia tego, co uznajemy za «swoje» czy «znane» - jak Makbet Szekspira (...)”. W takich rozważaniach ważną kategorią jest też czas, gdyż „inne napięcie tworzy spotkanie podmiotu i przedmiotu zbliżonego istnieniem w czasie, a inne - chwila, w której interpretacji poddawane są dzieła sprzed lat”. Zob. A. Pierzchała, Obcość przezwyciężona?, op.cit., s. 12.

58 Zob. na ten temat m.in. W. Laskowska-Smoczyńska, P. Kletowski (red.), Akira Kurosawa - twórca japoński, twórca światowy, Kraków 2011, s. 69-109. 
Podsumowując, najtrudniejsze są pytania, które w pierwszej chwili wydają się zupełnie proste. Wschód i Zachód w twórczości Kurosawy? To przecież wiadomo. Inspiracje, adaptacje, obrazy, książki, muzyka, życiowe doświadczenia, miejsca, idee. Można je wyliczyć, nawet przeanalizować na konkretnym przykładzie. Problemem jest zamknąć ten ogrom w jednym, lakonicznym zdaniu, które wyjaśnia wszystko. Kim jest Akira Kurosawa przede wszystkim? Artystą Wschodu? Azjatą? Japończykiem? Moja odpowiedź brzmi: jest przede wszystkim Artystą. Człowiekiem żyjącym poza konkretnym czasem i określoną przestrzenią... zawsze pomiędzy, na przecięciu różnic, granicy przepaści, ale i o krok od łączących wszystko mostów.

\section{Bibliografia}

Barthes R., Imperium znaków, tłum. A. Dziadek, Warszawa 2004.

Benedict R., Chryzantema i miecz. Wzory kultury japońskiej, tłum. E. Klekot, Warszawa 2003.

Bibliografia twórczości Akiry Kurosawy w języku polskim także na stronie: http://www.filmpolski.pl/fp/index.php/ $\mathrm{rec} / 514$.

Bobrowski M., Droga, która stoi wyżej niż sprawiedliwość etyczne poglady Akiry Kurosawy, „Studia Filmoznawcze” 2007, nr 28.

Burszta W.J., Różnorodność i tożsamość. Antropologia jako kulturowa refleksyjność, Poznań 2004.

Casrdullo B., Out of Asia. The films of Akira Kurosawa, Satyajit Ray, Abbas Kiarostami, and Zhang Yimou. Essays and interviews, Newcastle 2008. 
Grzonka D., Akira Kurosawa: Rytuaty przemocy i szekspirowski teatr zazdrości, styczeń 2011 https://www.researchgate.net/publication/323738121_Akira_Kurosawa_Rytualy_przemocy_i_szekspirowski_teatr_zazdrosci.

Helman A., Akira Kurosawa, Warszawa 1970.

Hillenbrand M., Hero, Kurosawa and a cinema of the senses, „Screen” 2013, vol. 54, nr 2.

Janicki S., Film japoński, Warszawa 1982.

Kamiński Ł., O twórczości cesarza kina japońskiego w 100. rocznice urodzin, „Humanistyka i Przyrodoznawstwo” 2014, nr 20.

Kletowski P., Kino Dalekiego Wschodu, Warszawa 2009.

Kitarō N., Starożytne formy kulturowe Wschodu i Zachodu w perspektywie metafizycznej, tłum. A. Kozyra, „Japonica” 1999, nr 10.

Kamrowska A., Przeszłość i teraźniejszość w filmach „jidaigeki” Akiry Kurosaway, [w:] Okna na przyszłość z historii wizualnej. Szkice z historii wizualnej, red. D. Skotarczak, J. Szymala, t. 2, Kraków 2020.

Kurosawa A., Ran, tłum. T. Shishido, Boston 1986.

Laskowska-Smoczyńska W., Kletowski P. (red.), Akira Kurosawa - twórca japoński, twórca światowy, Kraków 2011. Loska K., „Ran”, czyli Szekspir po japońsku, „Kwartalnik Filmowy" 2014, nr 87-88.

Minear R.H., Orientalism and the Study of Japan, „Journal of Asian Studies" 1980, vol. 39, nr 27.

Niogret H., Śnieg i popiót, tłum. T. Szczepański, „Film na Świecie" 1990, nr 11-12.

Pierzchała A., Pajęcze gniazdo. Wokót „Makbeta” Akiry Kurosawy, „Kwartalnik Filmowy” 1999, nr 26-27.

Pierzchała A., Film japoński a kultura europejska, Kraków 2005. 
Pierzchała A., Wietrzny syn, „Film” 1999, nr 4.

Obayashi N., Metoda Kurosawy, tłum. T. Szczepański, „Film na Świecie" 1990, nr 11-12.

Osiem snów samuraja. Wywiad z Akirą Kurosawą, „Film” 1990, nr 3.

Sartwell C., Six Names of Beauty, London 2013.

Sawicki P., Malowanie ruchem. Znaczenie obrazu w filmie Akiry Kurosawy, „Kwartalnik Filmowy” 2009, nr 65.

Sawicki P., Kurosawa, Wrocław 2015.

Szacki J., O kanonie kultury europejskiej uwagi sceptyczne, „Znak” 1994, nr 470, https://opoka.org.pl/biblioteka/I/ IS/kanon03.html.

Szarota P., Japoński uśmiech: orientalistyczna inwencja czy skrypt kulturowy?, https://www.researchgate.net/publication/267151989_Japonski_usmiech_orientalistyczna inwencja_czy_skrypt_kulturowy_The_Japanese_smile_ An_Oriental_invention_or_a_cultural_script.

Tasiemska M., „Sny” Akiry Kurosawy. Mit, symbol, rytuat, Warszawa 2018.

Tessier M., Wyśnione życie, tłum. J. Sacharewicz, „Kino” 1990, nr 9.

Wierzbicka A., Kisses, Handshakes, Bows: The Semantics of Nonverbal Communication, „Semiotica” 1995, vol. 103, nr 45. Wierzbicka A., Understanding Cultures Through Their Key Words: English, Russian, Polish, German, and Japanese, New York 1997.

Wierzbicka A., Emotions Across Languages and Cultures:

Diversity and Universals, Cambridge 1999.

Wilkoszewska K. (red.), Estetyka japońska, Kraków 2001-2004 .

Wierzbicka A., Stowa klucze. Różne języki - różne kultury, tłum. I. Duraj-Nowosielska, Warszawa 2016. 
Zaremba-Penk J., Lisiecki M., Człowieczeństwo bez granic. Wymiary kultury w twórczości Akiry Kurosawy, Bydgoszcz 2015.

\begin{abstract}
Abstrakt
Tematem tekstu jest analiza synergii kultury Wschodu i Zachodu na przykładzie filmu Ran z 1985 r. japońskiego reżysera Akiry Kurosawy (1910-1998). Wskazany film jest autorską adaptacją sztuki angielskiego dramatopisarza Wiliama Szekspira Król Lear z 1605 r. Celem rozważeń jest wskazanie inspiracji Kurosawy sztuką Zachodu (literatura, sztuki wizualne i muzyka), które mieszczą się w sferze dialogu międzykulturowego oraz związków teraźniejszości z przeszłością we wskazanym projekcie. Efektem tych badań będzie próba wskazania cienkiej granicy między afirmacją a oporem wobec tradycji rodzimej, po której „poruszał się” twórca Pijanego anioła. Metodologia to analiza filmoznawcza i badania porównawcze.
\end{abstract}

Słowa kluczowe: Akira Kurosawa (1910-1998), kino japońskie, dialog międzykulturowy, Ran (1985)

\begin{abstract}
The subject of the text is the analysis of the synergy between East and West, based on the example of Akira Kurosawa (1910-1998) film Ran from 1985 (an adaptation of William Shakespeare's play King Lear from 1605). The purpose of the considerations is to indicate and describe Kurosawa's inspiration for the East, present and past in the indicated project. The effect of these deliberations will be an attempt to indicate the fine line between affirmation and resistance to the tradition along which the creator of the Drunken Angel was moving. The methodology used in the research is film studies and comparative studies.
\end{abstract}

Keywords: Akira Kurosawa (1910-1998), Japanese cinema, intercultural dialogue, Ran (1985) 


\section{Dorota Kamińska-Jones}

Uniwersytet Mikołaja Kopernika w Toruniu

ORCID ID: https: / /orcid.org/0000-0002-2652-0966

\section{Tradycja i współczesność w kulturze indyjskiej na przykładzie świata urody kobiety}

W Indiach zawsze bardzo dużą wagę przywiązywano do urody, higieny i odpowiedniej dbałości o zdrowie. Kosmetyki, makijaż, upiększanie i pielęgnacja ciała, stosowanie wonności stanowiły zawsze bardzo istotne elementy życia człowieka, a szczególnie kobiet. W czasach współczesnych nadal przetrwało wiele z tradycyjnych przekonań i wiele zwyczajów jest nadal kontynuowanych. Wobec niektórych z nich narasta jednak stopniowy opór społeczny i prowadzone są kampanie na rzecz ich zniesienia. Z drugiej jednak strony, po chwilowym zachwycie zachodnimi produktami w XX w., zauważalny jest też powrót do naturalnych metod pielęgnacji, mających swoje źródła w tradycyjnej kosmetologii, w tym w Ajurwedzie.

Ludzie on najdawniejszych czasów używali środków pielęgnujących i upiększających. W Indiach najstarsze ślady ich stosowania odkryte zostały w Cywilizacji Doliny Indusu (ok. 2500 p.n.e.-1800 p.n.e.). Podczas wykopalisk natrafiono na obiekty służące do przechowywania i nakładania kosmetyków ${ }^{1}$. Z okresu wedyjskiego (ok. 1200 p.n.e.-800 p.n.e.)

1 N. Kumar, S. Gujarati, S. Gandharve, V. Kumar, History of Indian Concept of Cosmetology - A Review, „International Journal of Applied Ayurved Research", wrzesień-paździenik 2016, vol. II, nr 9, s. 1269. 
nie zachowało się wiele materialnych świadectw epoki. Na temat kosmetyków używanych w owym czasie informacji dostarczają najświętsze teksty hinduizmu - Wedy. W Rygwedzie znajduje się wiele fragmentów odnoszących się do malowania oczu kadźalem, zdobieniu żywymi kwiatami, perfumowaniu ciała i wiele innych ${ }^{2}$. Atharwaweda zwraca uwagę na zioła, które powodują poprawę kolorytu skóry, nadaniu blasku i koloru włosom, a także substancje i mieszanki o działaniu chłodzącym ciało.

W okresie postwedyjskim powstały natomiast bardzo kluczowe dzieła Ajurwedy, czyli indyjskiego systemu zdrowia. Najważniejsze z nich to Suśruta Samhita autorstwa Suśruty (ok. 600 p.n.e.), Ćaraka Samhita mędrca Ćaraki (ok. IV w. p.n.e.-II w. n.e.). Podstawowym założeniem Ajurwedy jest koncepcja, że człowiek stanowi integralną część wszechświata i złożony jest z tych samych elementów, czyli ziemi, wody, ognia, powietrza i eteru. Dla kosmetologii indyjskiej teksty ajurwedyjskie mają niezwykle ważne znaczenie. Trzeba jednakże zauważyć, że skupiają się one na aspektach zdrowotnych, a mniej na kosmetyce sensu stricte. Nie znaczy to jednak, że w ogóle nie zajmowały ją te kwestie i znajdziemy bardzo rozległą wiedzę dotyczącą odpowiedniego postępowania, aby jak najdłużej zachować zdrowie i urodę.

Więcej uwagi poświęcono kosmetologii w śastrach, a szczególnie kamaśastrach i dharmaśastrach. W pierwszej grupie największe znaczenie ma najstarszy zachowany tekst tego typu, czyli Kamasutra. Autor - Watsjajana Mallanaga jest zdania, że znajomość kosmetologii jest niezbędna we właściwym opanowaniu sztuki miłości i zalicza wiele z czynności kosmetycznych w skład 64 sztuk pomocnych

2 Ibidem. 
miłowaniu. Późniejsi autorzy, w tym Trymbakajadźwan autor jedynego zachowanego dzieła w całości poświęconego dharmie kobiecej - również podzielają to zdanie i opisują wiele działań o charakterze pielęgnacyjno-upiększającym w swoich traktatach.

W poezji późnego średniowiecza bardzo wiele uwagi poświęca się opisom czynności kosmetycznych, szczególnie wykonywanych przez kobiety. Szczególnym zainteresowaniem poetów cieszyły się opisy urody kobiecej od stóp do głów oraz sytuacje miłosne, w tym miłość od pierwszego wejrzenia, która często miała właśnie miejsce, kiedy kobieta dokonywała czynności higieniczno-kosmetycznych, a mężczyzna ujrzawszy ją w tej sytuacji - zakochiwał się bez pamięci.

Motyw kobiety podczas toalety występował również często w sztuce. Najstarsze przykłady znajdują się na reliefach ze stupy w Bharhucie. Szczególną popularność motyw ten osiągnął w malarstwie miniaturowym, przede wszystkim w XVII, XVIII i XIX w. w szkołach pochodzących z Radźasthanu i terenów leżących u stóp Himalajów. W sztuce nowoczesnej i współczesnej nadal artyści chętnie sięgali i nadal sięgają po ten motyw.

Motyw kobiety podczas toalety miał wiele różnych znaczeń w sztuce. W przedstawieniach rzeźbiarskich, na świątyniach hinduskich najczęściej należał do grona wyobrażeń przynoszących szczęście i zapewniających ochronę przed złem. Przedstawienia kobiet podczas wykonywania różnych czynności, średniowieczne śilpaśastry zalecają umieszczanie ich postaci. Np. Ślpa Prakaśa podaje, że „podobnie jak dom bez żony, jak igraszki bez kobiety, tak samo świątynia bez figury kobiecej posiada niższą wartość i nie przyniesie takich owoców jak ta z kobietami” i opisuje szesnaście 
typów kobiet (np. z lustrem, nakładającej makijaż), które należało umieszczać na świątyniach ${ }^{3}$. W malarstwie miniaturowym motyw ten miał wiele znaczeń. Najczęściej powiązany był z tematyką miłosną i stanowił pretekst do przedstawienia idealnego piękna bohaterki oraz momentu zakochania. Mógł też stanowić przedstawienie wizualizacji muzyki indyjskiej - ragamala.

W tradycji indyjskiej bardzo głęboko zakorzeniony jest wzorzec idealnego, kobiecego piękna. Obserwując dzieła sztuki, a także analizując teksty literackie, rozmaitego rodzaju - od traktatów naukowych, poprzez dzieła traktujące o właściwym wypełnianiu celów życia człowieka (dharmaśastry, kamaśastry), po poezje wyłania nam się podstawowy wzorzec kobiecej urody.

Bardzo ważnym elementem urody kobiecej jest jasna karnacja. Świetlistą skórę porównywano najczęściej do blasku księżyca. Przyczyny wykształcenia takiego wzorca urody, uchodzącego za idealny, można upatrywać już w czasach wedyjskich (ok. 1200 p.n.e.-800 p.n.e.), kiedy zaczęła się wykształcać teoria czterech warn, klas, na które podzielono społeczeństwo. Istotą takiego podziału była chęć odizolowania się plemion najeźdźców - jasnoskórych Ariów od ludności miejscowej, potrzeby zachowania przez nich nadrzędnej pozycji panów. Pierwotne bowiem znacznie słowa warna to kolor, rozumiany wtedy zapewne w kategoriach karnacji skóry. Najwyższa z klas miała oczywiście najjaśniejszą barwę, czyli taką, jaką mieli Ariowie. Od tego czasu powszechne stało się przekonanie, że biały kolor skóry jest lepszy od ciemnego, a co za tym idzie - piękniejszy. Kobieta, jeśli ma być urodziwa, musi mieć więc taką właśnie,

3 D. Desai, The Religious Imagery of Khajuraho, Mumbai 1996, s. 20. 
jasną karnację. Okres kolonialny, a szczególnie formalna dominacja brytyjska jeszcze utrwaliły przekonania o wyższości jasnej karnacji, która kojarzona była zarówno z urodą, jak i władzą.

Kobieta, wedle tradycyjnego wzorca urody, musiała być również być pięknie i kształtnie zbudowana. Za idealną sylwetkę uważano zaokrąglone kształty: wydatne piersi, okrągłe biodra, wąską talię, zaokrąglony brzuch z głębokim pępkiem. Z biologicznego punktu widzenia takie kształty charakteryzują kobiety charakteryzujące się statystycznie największą płodnością. Szczególnie ważna jest różnica w obwodzie talii, a bioder. Stąd też taki wygląd cechował idealną kobietę, taką, która potencjalnie stanowiła odpowiednią kandydatkę na żonę i matkę, z którą mężczyzna mógł przedłużyć swój ród.

Poza tymi głównymi cechami wyglądu, kobieta idealna musiała mieć również okrągłą twarz, najczęściej porównywaną do księżyca w pełni. Zestawienie to jest tak głęboko zakorzenione w kulturze, że do dziś w filmach indyjskich jest bardzo powszechne. Oczy idealnej Induski powinny być duże, o kształcie lotosu, a włosy tradycyjnie musiały być długie i gęste.

Wiele z tych przekonań oraz tradycyjny ideał urody zauważalne są w czasach współczesnych. Najważniejszym i niejako wszechobecnym jest umiłowanie jasnego koloru skóry. Szczególnie widoczne jest to w telewizji indyjskiej oraz na bilbordach i reklamach. Włączywszy jakikolwiek indyjski kanał, uderzające jest, jak wiele osób ma bardzo jasny kolor skóry, co znacznie kontrastuje z tym, co jest powszechnie widoczne na ulicach miast i wsi. Prezenterzy, aktorzy, osoby występujące w reklamach - znaczna większość ma bardzo rozświetlony kolor skóry. Co więcej, często 
do reklam typowo indyjskich produktów na lokalny rynek (jak np. sari) zatrudnia się modelki z Zachodu i nieco się je „indyzuje” poprzez makijaż, biżuterię czy rodzaj uczesania.

Mroczne oblicze podtrzymywania i lansowania takiego wzorca urody jest takie, że większość, szczególnie kobiet, pragnie się do niego dostosować, co jest powodem często głębokiej frustracji, ponieważ bardzo ciężko jest zmienić naturalny kolor skóry czy wręcz - niemożliwe (biorąc pod uwagę powszechnie stosowane środki). Często wręcz groźne, ponieważ niektóre z nich, szczególnie w nielegalnym obrocie, mogą zawierać niebezpieczne substancje, jak np. rtęć. Przeglądając choćby magazyny dla kobiet, widocznym się staje jak wielkie jest to źródło problemów. Listy od czytelniczek zdominowane są przez te właśnie zagadnienia, wiele artykułów poświęca się również omawianiem problematyki rozjaśniania skóry.

Osoby o ciemniejszym kolorze skóry doświadczają dyskryminacji, bardzo często od samego urodzenia, nawet we własnych rodzinach. Prześladowanie odbywa się więc w obrębie tej samej grupy etnicznej, co określa się jako rasizm wewnątrzrasowy (ang. intraracial). Ważne w kontekście dyskryminacji jest również przypisywanie cech psychicznych do danego typu urody. Przeświadczenie o bezpośredniej korelacji wnętrza i wyglądu jest głęboko zakorzenione w tradycji. Uważano, że im piękniejsza powierzchowność - tym lepsze cechy charakteru. W przypadku urody kobiecej jest to bardzo widoczne choćby w tradycyjnej klasyfikacji typów kobiet: padmini, ćitrini, śankhini i hastini. Najwyżej w hierarchii stała pierwsza z nich - kobieta-lotos, która prezentowała sobą wszystkie cechy idealnej urody (w tym jasną skórę) oraz charakteru. Ostatnia z nich - kobieta-słonica - posiadała najmniej pożądane cechy fizyczne i psychicz- 
ne. Takie przekonanie funkcjonuje niestety do dnia dzisiejszego - osoby jasnej karnacji postrzegane są najczęściej za "czyste", dobrze zadbane, wartościowe, religijne, należące do elity, natomiast o ciemnych skórach - jako posiadające gorsze usposobienie, „nieczyste”, pochodzące z niższych warstw społecznych, a także niekiedy bardziej rozwiązłe seksualnie. Najbardziej widoczne jest to na rynku matrymonialnym tam otwarcie się mówi o wyższej wartości osób jasnoskórych. Szczególnie dotyka to właśnie kobiety, które często postrzegane są jako „dobro” przyszłego małżonka, świadczące o jego statusie. Pożądane są więc kobiety jasnoskóre, natomiast te o ciemniejszej karnacji nie cieszą się zainteresowaniem, co więcej, często rodzina przyszłego pana młodego domaga się większego posagu, jako rekompensaty za ten "defekt”. Działa to też w odwrotną stronę - kobieta z niższej kasty, ale o jaśniejszej karnacji, może poślubić mężczyznę z wyższej kasty. Jasna skóra jest więc przepustką do wyższej warstwy społecznej ${ }^{4}$. Drugim obszarem, w którym ta dyskryminacja jest bardzo widoczna to rynek pracy - na wielu eksponowanych stanowiskach wymagana jest jasna skóra, o czym często otwarcie mówi się podczas rekrutacji.

Nic więc dziwnego, że tradycyjna kosmetologia oraz firmy kosmetyczne bardzo się skupiają na tym aspekcie, a największe zyski w tej branży notuje się w obszarze preparatów do rozjaśniania skóry (jego wartość szacuje się na około 4 mld dolarów). Obecnie na rynku indyjskim duże znacze-

4 K.K. Dhillon-Jamerson, Marketing Marriage and Colorism in India, [w:] Race in the Marketplace Crossing Critical Boundaries, red. G.D. Johnson, K.D. Thomas, A.K. Harrison, S.A. Grier, Basel 2019; N. Kullrich, In This Country, Beauty Is Defined by fairness of Skin.' Skin Colour Politics and Social Stratification in India, [w:] Beauty and the Norm Debating Standardization in Bodily Appearance, red. C. Liebelt, S. Böllinger, U. Vierke, Basel 2019. 
nie mają firmy międzynarodowe, wśród których najbardziej popularne to: L'Oreal, Garnier, Nivea czy Pond's. Firmy te dostosowują swoją ofertę do rynku lokalnego i wprowadzają tam nowe, specyficzne produkty. Jednymi z nich są właśnie preparaty do rozjaśniania skóry. Sektor ten jest bardzo bogaty w rozmaite preparaty, mające często oprócz wybielania, także dodatkowe działania i zapewniające całościową pielęgnację, jak mycie (np. Garnier Skin Naturals White Complete Face Wash), nawilżanie (L'Oreal Paris White Perfect Day Cream, Nivea Whitening Cream), odżywianie i odbudowę (POND'S White Beauty Night Cream), redukcję porów (Nivea Visage White Cell Repair Pore Minimizer Day Cream), zmarszczek (Nivea Visage Q10 Plus Creatine Anti Wrinkle Day Cream), ochronę przeciwsłoneczną (np. Nivea Sun Face Whitening Cream SPF 50), pielęgnację całego ciała (Nivea Extra White Firming Body Serum), a niekiedy nawet przeznaczone dla konkretnej płci (np. Garnier Man Power Light, L'Oreal Paris Men Expert White Activ Skin Whitening Moisturizer). Indyjskie firmy mają również w swojej ofercie mocną reprezentację produktów rozjaśniających. Najstarsze z nich, nadal bardzo prężnie działające, to przede wszystkim Himalaya (zał. 1930 r., Himalaya Clear Complexion Whitening Day Cream) i Dabur (zał. 1884 r., Fem Fairness Naturals Professional Gold Cream Bleach), a z młodszych rynek podbija między innymi Patanjali Ayurved (zał. 2006 r., Saundarya Swarn Kanti Fairness Cream). Najważniejszym graczem jednak w tym sektorze jest niewątpliwie Hindustan Unilever Limited (HUL) ze swoim flagowym produktem Fair\&Lovely (obecnie Glow\&Lovely). Oprócz tego na indyjskich platformach handlowych jak amazon.in obecnych jest bardzo wiele artykułów z rozmaitych firm mających w swojej ofercie produkty wybielające do różnych części 
ciała, w tym zyskujące coraz większą popularność rozjaśniacze do stref intymnych, jak bikini czy nawet wybielacze waginalne. Firmy te prowadzą bardzo aktywną działalność reklamową - od spotów telewizyjnych po billboardy do wzmianek w prasie. Przekaz koncentruje się głównie wokół kilku głównych zagadnień: jaśniejsza skóra daje szansę na lepsze zamążpójście, lepszą pracę, lepsze relacje partnerskie i lepsze, szczęśliwsze życie. Schemat takiej reklamy jest zazwyczaj podobny: ciemna osoba jest niezuważona/ignorowana/porzucana/nieszczęśliwa/nie może znaleźć zatrudnienia - po zastosowaniu preparatu uzyskuje jaśniejszy kolor skóry i problem, z którym się borykała - znika - staje się zauważona/podziwiana/kochana/wraca do niej miłość/jest szczęśliwa/znajduje pracę. Najczęściej też przedstawia się stadia rozjaśniania skóry - od najciemniejszej - a w trakcie stosowania preparatu - coraz jaśniejszej, aż do osiągnięcia bardzo jasnej i rozświetlonej. Reklamy te powodują bardzo negatywne skutki społeczne - lansowanie takiego przekazu wzbudza frustrację, lęk, niezadowolenie z siebie i dalsze, często bardzo dramatyczne skutki (choroby, wykluczenie z rynku pracy itp. $)^{5}$.

Stopniowo pojawia się coraz większy sprzeciw wobec tego wzorca urody, najczęściej nierealnego oraz wielokrotnie otwarcie rasistowskich reklam. Jedna z najważniejszych tego typu kampanii jest prowadzona przez organizację pozarządową Women of Worth pt. Dark is Beautiful (początek 2013 r.) ${ }^{6}$. Dyrektor kampanii Kavitha Emmanuel powiedziała, że była ona rezultatem pracy z młodymi ludźmi, szcze-

5 K. Maran, S.V. Rekha, Advertisements Impact on Body Image Investment Practices of Women in India, „Global Media Journal”, 2012, vol. $3, \mathrm{n} 1$.

6 https://www.darkisbeautiful.in. 
gólnie dziewczętami, które czują się źle z faktu posiadania ciemniejszej skóry. Uważa ona, że uprzedzenia względem karnacji dotykają głęboko psychiki ludzkiej. Wpływają nawet na to jak uczennice zachowują się w szkole, tracą one pewność siebie, czują się niewystarczająco dobrze z powodu ciemniejszej skóry. Dyskryminacja i poniżenie spotyka je następnie na rynku matrymonialnym. Postanowiła więc ona zaczać walczyć z tymi przeświadczeniami, mając nawet świadomość, że może to potrwać bardzo długie lata. „Nasza kampania podkreśla to, że w kraju, w którym występuje tyle kolorów skóry, powinniśmy doceniać każdy z nich"7. Organizacja prowadzi rozmaite kampanie: po zbieranie podpisów pod petycjami mającymi na celu wycofanie rasistowskich reklam, po prowadzenie kampanii edukacyjnych czy też angażowanie gwiazd, które publikują swoje fotografie bez retuszu z krótkim komentarzem i hasłem: Dark is Beutiful. Stay UNFair. Stay Beautiful (np. aktorka Vishakha Singh, która od siebie dodała: Nie szukaj potwierdzenia u innych. Nie przepraszaj za kolor swojej skóry. Ucz swoje dzieci większej wrażliwości. Celebruj każdy odcień piękna).

Stopniowo kampanie tego typu zaczynają odnosić sukcesy. Najważniejszym z nich jest niewątpliwie wymuszenie zmiany nazwy flagowych indyjskich produktów do rozjaśniania skóry: Fair \& Lovely na Glow \& Lovely oraz Fair\&Handsome na Glow\&Handsome. Są to bardzo powolne zmiany, ale przynoszą nadzieję na zmianę podejścia do koloru skóry.

W odwrotną stronę zmiany zachodzą w postrzeganiu wzorcowej figury kobiecej. Wraz z coraz większymi wpływami kultury zachodniej, a co za tym idzie - również pro-

7 https://www.theguardian.com/sustainable-business/blog/skinwhitening-cream-dark-side-beauty-industry. 
mowanym tam preferowanym wyglądzie kobiet - szczupłych, wysportowanych, zauważalne jest stopniowa zmiana również w gustach indyjskich, zachodząca mniej więcej od lat 80. XX w. ${ }^{8}$ Taki wygląd coraz częściej preferowany jest wśród aktorek bollywoodzkich, a co za tym idzie, poprzez popularność tych produkcji, również wśród mieszkanek Indii. Należy zauważyć, że wpływy te widoczne są przede wszystkim na północy i w dużych miastach. Na południu dużą popularnością cieszą się filmy wyprodukowane w lokalnych studiach filmowych (np. w języku tamilskim), a tam nadal dominują tradycyjne wzorce urody. Jednakże i w tym regionie, szczególnie u nastolatek i młodych kobiet, coraz bardziej zauważalne jest stopniowe podążanie za zachodnimi standardami ${ }^{9}$. W dużych miastach, wśród wykształconych i dobrze sytuowanych kobiet widoczna jest tendencja do podążania za zachodnimi standardami sylwetki kobiecej. Co za tym idzie, promowana jest moda na bycie „fit” - kobiety nakłaniane są do dbanie o utrzymanie wysportowanej i szczupłej sylwetki. Pociąga to za sobą rozkwit centrów, które zaspokajają takie potrzeby, w tym siłowni dla kobiet. Mroczną stroną podążania za zachodnimi wzorcami jest alarmujący wzrost zaburzeń żywieniowych, w tym szczególnie bulimii i anoreksji ${ }^{10}$.

8 S. Munshi, Marvellous Me: The Beauty Industry and the Construction of the 'Modem' Indian Woman, [w:] Images of the 'Modern Woman' in Asia: Global Media, Local Meanings, red. S. Munshi, London-New York 2001.

9 L. Unnikrishnan, R. Prasad, The Impact of Globalization on the Perception of Beauty Among South Indian Women, 2016 Intl. Conference on Advances in Computing, Communications and Informatics (ICACCI), 21-24 września 2016, Jaipur, India

10 K. Singh, Anorexia Rising at an Alarming Rate, „The Times of India", 18.07.2007; D.N. Mendhekar, K. Arora, D. Lohia, A. Aggarwal, R.C. Jiloha, Anorexia Nervosa: An Indian Perspective, „The National 
Kolejna tradycyjna cecha idealnej kobiecej urody - długie, zadbane włosy, nadal jest bardzo rozpowszechniona. Wśród wykształconych elit pojawiają się warianty tradycyjnych uczesań - wprowadza się nieznaczne fale, nieco krótsze włosy czy też koloryzację (dominują jednak kolory ciemne). Na krótkie fryzury kobiety indyjskie decydują się niezwykle rzadko. W dużych miastach można spotkać panie noszące takie uczesanie, jednak zazwyczaj są to uczone, feministki, niezależne kobiety lub też osoby bardzo podążające za zachodnim stylem życia. Te, które zdecydowały się na taki krok, wspominają często, że spotkało się to z ogromnym szokiem i niedowierzaniem najbliższego środowiska. Jedna z nich, obecnie dorosła kobieta, wspomina, że kiedy na studiach zdecydowała się ściąć włosy, rodzina przeżyła szok. „Nigdy nie zapomnę przerażenia i niedowierzania na twarzach bliskich, kiedy tego dnia wróciłam do domu. Co więcej, nadal mi tego do końca nie wybaczyli, że pozbyłam się swoich loków i do dziś podczas spotkań rodzinnych, ku mojemu zawstydzeniu, nadal to wspominają" ${ }^{11}$.

Produkty, które stosują do pielęgnacji współczesne mieszkanki Indii są różnorodne. Nadal, tak jak w poprzednik wiekach, kobiety przywiązują bardzo dużą wagę do odpowiedniej pielęgnacji. Duży udział na rynku, jak wspomniano, odgrywają koncerny międzynarodowe. Obecnie zauważalny jest stopniowy odwrót od zachodnich kosme-

Medical Journal of India" 2009, vol. 22, nr 4; R. Gelles, Fair and Lovely: Standards of Beauty, Globalization, and the Modern Indian Woman, "Independent Study Project (ISP) Collection" 2011, 1145; S. Singh, P. Gadiraju, Prevalence and Correlates of Body Dissatisfaction and Disordered Eating Patterns in Indian Youth: The Role of Media, „Indian Journal of Psychiatry" 2020, vol. 62, nr 5.

11 M. Bharadwaj, India's Beauty Secrets. Natural Solutions for Body and Soul, London 2008, s. 50. 
tyków na rzecz rodzimych firm. Powstaje też coraz więcej koncernów, które wracają do tradycyjnych receptur i naturalnych składników. Warto jednak podkreślić, że owa tendencja dotyczy raczej większych ośrodków, odbiorcy, głównie kobiety, zauważają zgubne skutki stosowania chemicznych preparatów. Obserwując mieszkanki Indii jest to bardzo widoczne - w dużych miastach znacznie większy jest procent kobiet, które borykają się z problemami z cerą czy włosami. Natomiast w małych miasteczkach czy wsiach nadal przeważnie cieszą się brakiem tego typu dolegliwości. Co jednak ciekawe, stopniowo i one zaczynają stosować kosmetyki zachodnie, uważając to za luksus. Kobiety z miast natomiast, po przykrych doświadczeniach z nimi, często wracają do własnej tradycji. Coraz bardziej powszechna jest też duma z powodu indyjskich systemów zdrowotnych, szczególnie Ajurwedy. We współczesnych Indiach coraz silniej akcentuje się przywiązanie do własnej tradycji, szczególnie tej związanej z hinduizmem. Na tej fali coraz większą popularnością zaczynają się cieszyć produkty, które się do niej odnoszą, a szczególnie do Ajurwedy. Rynek pełen jest teraz produktów „ajurwedyjskich”, „bazujących na dawnych recepturach". Naczelna zasada kosmetologii ajurwedyjskiej mówi, że można na ciało nałożyć tylko to, co nadaje się do spożycia. Analizując składy tych kosmetyków wyraźne jest, jak często słowo „Ajurweda” jest magnesem, natomiast użyte składniki nie mają z nią często nic wspólnego. Są też firmy, które podążają za tymi wytycznymi i koncentrują się na naturalnych składnikach.

Kobiecy świat urody w Indiach ulega więc stopniowym zmianom. Zauważalne jest, że kobiety domagają się uznania ich takimi, jakimi są, szczególnie w kwestii koloru skóry (np. konkurs Miss Indii coraz bardziej kładzie nacisk na 
prezentowanie różnych kolorów skóry) ${ }^{12}$, a także walczą o wolność w kształtowaniu swojego wizerunku (np. krótkie włosy). Z drugiej jednak strony coraz większe podążanie za modą z Zachodu powoduje nowe frustracje i kolejne, często nierealne wymagania (bardzo szczupła, sportowa sylwetka). Pozytywnym aspektem jest niewątpliwie coraz powszechniejszy powrót do własnych tradycji kosmetycznych i stosowanie naturalnych preparatów. Tak więc obecnie ścierają się w Indiach dwie mocne tendencje - z jednej strony walka z rasizmem i dyskryminacją, podkreślanie przywiązania do indyjskich tradycji; a z drugiej coraz silniejsza penetracja zachodnich wzorców urody. Jest to problem nie tylko indyjski, ale globalny ${ }^{13}$, szczególnie widoczny w krajach azjatyckich w których kobiety chcą być jak najbardziej „zachodnie” (np. biała skóra), ale jednocześnie też „lokalne”, podkreślając przymioty własnej kultury i naturalnych metod tamtejszej pielęgnacji. Wymagania takie są w większości nierealne, powodują wiele frustracji, zaburzeń, a nawet poważnych chorób. Kobiecy świat urody musi być obecnie zredefiniowany - powrót do naturalnej pielęgnacji powinien również pociągnąć za sobą akceptację każdej kobiecej urody, skupiać się na utrzymaniu jej w zdrowiu, dobrej kondycji i podkreślać naturalne piękno, zamiast podążać za nierealnymi wyobrażeniami.

12 N. Shevde, All's Fair in Love and Cream: A Cultural Case Study of Fair E Lovely in India, „Advertising \& Society Review” 2008, vol. 9, nr 2.

13 Zob. np. K. Harper, B.L. Choma, Internalised White Ideal, Skin Tone Surveillance, and Hair Surveillance Predict Skin and Hair Dissatisfaction and Skin Bleaching among African American and Indian Women, „Sex Roles” 2019, vol. 80, nr 11/12; A. Jill Thompson, S. Poyrazli, E. Miller, Western Media and Body Image Dissatisfaction in Young Women in Developing Nations, „Eurasian Journal of Educational Research” 2020, vol. 90. 


\section{Bibliografia}

Bharadwaj M., India's Beauty Secrets. Natural Solutions for Body and Soul, London 2008.

Desai D., The Religious Imagery of Khajuraho, Mumbai 1996.

Dhillon-Jamerson K.K., Marketing Marriage and Colorism in India, [w:] Race in the Marketplace Crossing Critical Boundaries, red. G.D. Johnson, K.D. Thomas, A.K. Harrison, S.A. Grier, Basel 2019.

Gelles R., Fair and Lovely: Standards of Beauty, Globalization, and the Modern Indian Woman, „Independent Study Project (ISP) Collection" 2011, 1145.

Harper K., Choma B. L., Internalised White Ideal, Skin Tone Surveillance, and Hair Surveillance Predict Skin and Hair Dissatisfaction and Skin Bleaching among African American and Indian Women, „Sex Roles” 2019, vol. 80, nr 11/12. Jill Thompson A., Poyrazli S., Miller E., Western Media and Body Image Dissatisfaction in Young Women in Developing Nations, „Eurasian Journal of Educational Research” 2020, vol. 90.

Johnson G.D., Thomas K.D., Harrison A.K., Grier S.A. (red.), Race in the Marketplace Crossing Critical Boundaries, Basel 2019.

Kullrich N., In This Country, Beauty Is Defined by fairness of Skin.' Skin Colour Politics and Social Stratification in India, [w:] Beauty and the Norm Debating Standardization in Bodily Appearance, red. C. Liebelt, S. Böllinger, U. Vierke, Basel 2019.

Kumar N., Gujarati S., Gandharve S., Kumar V., History of Indian Concept of Cosmetology - A Review, „International Journal of Applied Ayurved Research", wrzesień-październik 2016, vol. II, nr 9. 
Maran K., Rekha S.V., Advertisements Impact on Body Image Investment Practices of Women in India, „Global Media Journal" 2012, vol. 3, nr 1.

Mendhekar D.N., Arora K., Lohia D., Aggarwal A., Jiloha R.C., Anorexia Nervosa: An Indian Perspective, „The National Medical Journal of India” 2009, vol. 22, nr 4.

Munshi S. (red.), Images of the 'Modern Woman' in Asia: Global Media, Local Meanings, London-New York 2001. Munshi S., Marvellous Me: The Beauty Industry and the Construction of the 'Modem' Indian Woman, [w:] Images of the 'Modern Woman' in Asia: Global Media, Local Meanings, red. S. Munshi, London-New York 2001.

Yip J., Ainsworth S., Hugh M.T., Beyond Whiteness: Perspectives on the Rise of the Pan-Asian Beauty Ideal, [w:] Race in the Marketplace Crossing Critical Boundaries, red. G.D. Johnson, K.D. Thomas, A.K. Harrison, S.A. Grier, Basel 2019.

Singh K., Anorexia Rising at an Alarming Rate, „The Times of India", 18.07.2007.

Singh S., Gadiraju P., Prevalence and Correlates of Body Dissatisfaction and Disordered Eating Patterns in Indian Youth: The Role of Media, "Indian Journal of Psychiatry” 2020, vol. 62, nr 5.

Shevde N., All's Fair in Love and Cream: A Cultural Case Study of Fair E Lovely in India, "Advertising \& Society Review" 2008, vol. 9, nr 2.

Unnikrishnan L., Prasad R., The Impact of Globalization on the Perception of Beauty Among South Indian Women, 2016 Intl. Conference on Advances in Computing, Communications and Informatics (ICACCI), 21-24 września 2016, Jaipur.

Vijaya R.M., The New Economics of Colorism in the Skin 
Whitening Industry: Case of India and Nigeria, [w:] Race in the Marketplace Crossing Critical Boundaries, red. G.D. Johnson, K.D. Thomas, A.K. Harrison, S.A. Grier, Basel 2019.

\begin{abstract}
Abstrakt
Tematem artykułu jest świat kobiecej urody. Podzielony jest on na trzy zasadnicze części. Pierwsza zajmuje się tym zagadnieniem z perspektywy historycznej. Wskazano jak wielką wagę przykładano w Indiach do pielęgnacji i upiększania. Opisano także tradycyjny ideał urody kobiecej - jasną karnację, długie włosy, okrągłą twarz, zaokrągloną sylwetkę ze szczupłą talią. W drugiej części skupiono się na czasach obecnych. Przeanalizowano przede wszystkim takie zagadnienia, jak wybielanie skóry, trwałość wzorców urody co do wyglądu włosów, natomiast stopniową zmianę w preferowanym typie sylwetki. W ostatniej części omówiono problematykę kosmetyków używanych obecnie w Indiach - od fascynacji zachodnimi produktami do stopniowego powrotu do własnych tradycji, szczególnie Ajurwedy.
\end{abstract}

Słowa kluczowe: kosmetologia indyjska, indyjski ideał urody, rozjaśnianie skóry, przemysł kosmetyczny

\begin{abstract}
This article deals with the world of female beauty and is divided into three main sections. The first deals with this issue from a historical perspective, showing how much importance was attached to care and beautification in India. The traditional ideal of female beauty is also described - fair skin, long hair, a round face, a rounded figure with a slim waist. The second part focuses on the present day, mainly on issues such as skin whitening, the durability of beauty patterns in terms of hair appearance, and a gradual change in the preferred type of figure. The final part discusses the issues of cosmetics cur-
\end{abstract}


rently used in India - from the fascination with Western products to a gradual return to their own traditions, especially Ayurveda.

Keywords: Indian cosmetology, Indian beauty ideal, skin lightening, cosmetics industry 